VILNIAUS GEDIMINO TECHNIKOS UNIVERSITETAS, VALSTYBINIS MOKSLINIŲ TYRIMUৃ INSTITUTAS

FIZINIŲ IR TECHNOLOGIJOS MOKSLŲ CENTRAS

Edvardas BIELSKIS

\title{
ENERGETIŠKAI EFEKTYVAUS \\ FOTOVOLTINIO MIKROINVERTERIO KŪRIMAS
}

DAKTARO DISERTACIJA

TECHNOLOGIJOS MOKSLAI, ELEKTROS IR ELEKTRONIKOS INŽINERIJA (T 001) 
Disertacija rengta 2014-2020 metais Valstybiniame mokslinių tyrimų institute Fizinių ir technologijos mokslų centre.

\section{Vadovas}

prof. dr. Algirdas BAŠKYS (Valstybinis mokslinių tyrimų institutas Fizinių ir technologijos mokslų centras, elektros ir elektronikos inžinerija - T 001).

Vilniaus Gedimino technikos universiteto elektros iš elektronikos inžinerijos mokslo krypties disertacijos gynimo taryba:

\section{Pirmininkas}

prof. dr. Dalius NAVAKAUSKAS (Vilniaus Gedimino technikos universitetas, elektros ir elektronikos inžinerija - T 001).

\section{Nariai:}

doc. dr. Saulius GUDŽIUS (Kauno technologijos universitetas, elektros ir elektronikos inžinerija - T 001),

prof. dr. Jurij NOVICKIJ (Vilniaus Gedimino technikos universitetas, elektros ir elektronikos inžinerija - T 001),

dr. Iouliia SKLIAROVA (Aveiro universitetas, Portugalija, elektros ir elektronikos inžinerija - T 001),

dr. Česlovas ŠIMKEVIČIUS (Valstybinis mokslinių tyrimų institutas Fizinių ir technologijos mokslų centras, elektros ir elektronikos inžinerija T 001).

Disertacija bus ginama viešame Elektros ir elektronikos inžinerijos mokslo krypties disertacijos gynimo tarybos posėdyje $2020 \mathrm{~m}$. rugsẻjo $28 \mathrm{~d}$. 10 val. Vilniaus Gedimino technikos universiteto senato posėdžių salëje.

Adresas: Sauletekio al. 11, LT-10223 Vilnius, Lietuva.

Tel.: (8 5) 274 4956; faksas (8 5) 270 0112; el. paštas doktor@ @gtu.lt

Pranešimai apie numatomą ginti disertaciją išsiųsti 2020 m. rugpjūčio 27 d.

Disertaciją galima peržiūrèti VGTU talpykloje http://dspace.vgtu.lt, Vilniaus Gedimino technikos universiteto bibliotekoje (Saulètekio al. 14, LT-10223 Vilnius, Lietuva) bei Lietuvos mokslų akademijos Vrublevskių bibliotekoje (Žygimantų g. 1, LT-01102 Vilnius, Lietuva).

VGTU leidyklos TECHNIKA 2020-026-M mokslo literatūros knyga http://leidykla.vgtu.lt

(C) VGTU leidykla TECHNIKA, 2020

(C) Edvardas Bielskis, 2020

edvardas.bielskis@su.lt 
VILNIUS GEDIMINAS TECHNICAL UNIVERSITY,

STATE RESEARCH INSTITUTE CENTER FOR PHYSICAL

SCIENCES AND TECHNOLOGY

Edvardas BIELSKIS

\section{DEVELOPMENT OF ENERGY EFFICIENT PHOTOVOLTAIC MICROINVERTER}

DOCTORAL DISSERTATION

TECHNOLOGICAL SCIENCES,

ELECTRICAL AND ELECTRONIC ENGINEERING (T 001)

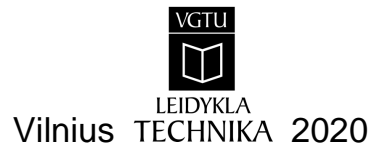


Doctoral dissertation was prepared at State Research Institute Center for Physical Sciencies and Technology in 2014-2020.

\section{Supervisor}

Prof. Dr Algirdas BAŠKYS (State research institute Center for Physical

Sciences and Technology, Electrical and Electronic Engineering - T 001).

The Dissertation Defence Council of Scientific Field of Electrical and Electronic Engineering of Vilnius Gediminas Technical University:

\section{Chairman}

Prof. Dr Dalius NAVAKAUSKAS (Vilnius Gediminas Technical University, Electrical and Electronic Engineering - T 001).

\section{Members:}

Assoc. Prof. Dr Saulius GUDŽIUS (Kaunas University of Technology, Electrical and Electronic Engineering - T 001),

Prof. Dr Jurij NOVICKIJ (Vilnius Gediminas Technical University, Electrical and Electronic Engineering - T 001),

Dr Iouliia SKLIAROVA (Aveiro University, Portugal, Electrical and Electronic Engineering - T 001),

Dr Česlovas ŠIMKEVIČIUS (State Research Institute Center for Physical Sciences and Technology, Electrical and Electronic Engineering - T 001).

The dissertation will be defended at the public meeting of the Dissertation Defence Council of Electrical and Electronic Engineering in the Senate Hall of Vilnius Gediminas Technical University at 10 a. m. on 28 September 2020.

Address: Sauletekio al. 11, LT-10223 Vilnius, Lithuania.

Tel.: +370 5274 4956; fax +370 5270 0112; e-mail: doktor@ vgtu.lt

A notification on the intend defending of the dissertation was send on 27 August 2020.

A copy of the doctoral dissertation is available for review at VGTU repository http://dspace.vgtu.lt, at the Library of Vilnius Gediminas Technical University (Sauletekio al. 14, LT-10223 Vilnius, Lithuania) and the Wroblewski Library of the Lithuanian Academy of Sciences (Žygimantu st. 1, LT-01102, Vilnius, Lithuania). 


\section{Reziumè}

Darbe siūlomi sprendimai ir atliekami tyrimai skirti fotovoltinio mikroinverterio naudingumo koeficiento didinimui bei jo tiekiamos srovès ị elektros tinklą netiesiniu iškraipymų mažinimui. Sukurtas ir eksperimentiškai ištirtas energetiškai efektyvus vienos pakopos fotovoltinis tinklo mikroinverteris. Sukurtas valdymo algoritmas ir ji igyvendinantis valdiklis tiekiamos $i \mathfrak{e}$ elektros tinklą mikroinverterio srovès valdymui.

Disertaciją sudaro ìvadas, trys skyriai, bendrosios išvados, naudotos literatūros ir autoriaus publikacijų disertacijos tema sąrašai.

Ivadiniame skyriuje aptariama tiriamoji problema, darbo aktualumas, aprašomas tyrimų objektas, formuluojamas darbo tikslas bei uždaviniai, aprašoma tyrimų metodika, darbo mokslinis naujumas, darbo rezultatų praktinė reikšmè, ginamieji teiginiai. Ivado pabaigoje pristatomos disertacijos tema autoriaus paskelbtos publikacijos ir pranešimai konferencijose bei disertacijos struktūra.

Pirmajame skyriuje atlikta fotovoltinių inverterių savybių mokslinių tyrimų analizè. Išanalizuoti fotovoltinių mikroinverterių veikimo principai, aptarti jų privalumai ir trūkumai, išanalizuotos mikroinverterio išejimo srovès valdymo sistemos. Apžvelgti mikroinverteriuse naudojami nuolatinès įtampos keitikliai. Suformuluoti disertacijoje uždaviniai.

Antrajame skyriuje pateikti sukurtų nuolatinès ịtampos grịžtamojo (angl. Flyback) keitiklio su alternatyvia aktyviaja viršįtampio gesinimo grandine ir dviejų raktų grịžtamojo keitiklio eksperimentiniai naudingumo koeficiento tyrimų rezultatai. Jie palyginti su klasikinio nuolatinès įtampos grįžtamojo keitiklio tyrimų rezultatais. Pasiūlytas naujas vienos pakopos fotovoltinis mikroinverteris, sukurtas naudojant du dviejų raktų grižtamuosius nuolatinès ịtampos keitiklius. Atlikti mikroinverterio naudingumo koeficiento ir išejimo itampos bei srovès tyrimai.

Trečiajame skyriuje pasiūlytas naujas proporcinis integralinis (PI) valdiklis su keičiamu laike proporciniu koeficientu, ištirta mikroinverterio srovès valdymo sistema su sukurtu valdikliu. Gauti mikroinverterio išèjimo srovès spektrai, įvertinti ir palyginti srovès netiesiniai iškraipymai. Ištirta mikroinverterio elementu parametrų ịtaka naudingumo koeficientui. Tyrimai atlikti eksperimentiškai bei modeliuojant. Sukurto mikroinverterio naudingumo koeficiento padidinimui, patobulintas jame naudojamas grịžtamasis transformatorius.

Pagrindiniai disertacijos rezultatai paskelbti 7 mokslinèse publikacijose - 5 iš jų atspausdinti recenzuojamuose mokslo žurnaluose, 2 konferencijų leidiniuose. Rezultatai viešinti 10 mokslinių konferencijų. 


\section{Abstract}

The aim of the performed research is to improve the efficiency of the photovoltaic grid tied microinverter and reduce the nonlinear distortions of the microinverter current supplied to the electricity network. An energy-efficient single-stage photovoltaic microinverter has been developed and investigated. The control algorithm and the controller has been developed for the tracking of sinus shape of the microinverter output current. The investigation was performed using simulation and experimentally.

The dissertation consists of an introduction, three chapters, general conclusions, references and the list of author's publications on the topic of the dissertation.

The research problem, the relevance of the work, the object of research are presented in the introductory chapter. The aim and objectives of the work, the research methodology, scientific novelty of the work, the practical significance of the work results, defended statements are presented as well. At the end of the introduction, the author's publications and conference papers on the topic of the dissertation and the structure of the dissertation are given.

In the first chapter, the research analysis of the properties of photovoltaic inverters is performed. The principles of operation of photovoltaic microinverters are analyzed, their advantages and disadvantages are discussed, microinverter output current control systems are analyzed. DC-DC (DC - direct current) voltage converters used in microinverters are reviewed. The tasks of the dissertation are formulated.

The experimental investigation results of efficiency of a developed DC-DC voltage flyback converter with an alternative active surge suppression circuit and a two-switch DC-DC flyback converter are presented in the second chapter. A new single stage grid tied photovoltaic microinverter based on couple of twoswitch DC-DC flyback converters has been proposed. The investigation of proposed microinverter efficiency was performed.

In the third chapter a new PI controller with a time-varying proportional constant is proposed and a microinverter output current sinus shape tracking system with a developed controller was investigated. The nonlinear distortions of the current were evaluated. The influence of parameters of the microinverter elements on the microinverter efficiency was investigated. The flyback transformer used in the microinverter has been upgraded.

The main results of the dissertation have been published in 7 scientific publications -5 of them have been published in peer-reviewed scientific journals, 2 in conference proceedings. The results were presented at 10 scientific conferences. 


\section{Žymèjimai}

$B_{\text {sot }}$ - magnetolaidžio šerdies sotinimosi taško magnetinio srauto tankis;

$D$ - impulso pločio skvarba;

$e$ - paklaidos signalas;

$F$ - magnetovara oro tarpelyje;

$H$ - magnetinio lauko stipris;

$I$ - elektros srove;

$I_{\mathrm{sp}}$ - grižžtamojo transformatoriaus magnetinio sklaidos srauto kuriama srové;

$K_{\mathrm{D}}-$ diferencijuojantis koeficientas;

$K_{\mathrm{I}}-$ integruojantis koeficientas;

$K_{\mathrm{P}}-$ proporcinis koeficientas;

$K_{\mathrm{r}}$ - rezonansinio nario pastovioji;

$K_{\mathrm{V}}$ - laike kintančio koeficiento dedamoji;

$l_{\mathrm{w}}$ - transformatoriaus magnetolaidžio šerdies ilgis;

$n_{1}$ - antrinès ir pirminès apvijų vijų skaičius;

$n_{2}$ - antrinès ir pirminès apvijų vijų skaičius;

$P_{\text {nuost. }}$ - elektros galios nuostoliai;

$r_{1}$ - transformatoriaus pirminès apvijos aktyvinè varža; 
$r_{2}-$ transformatoriaus antrinès apvijos aktyvinè varža;

$R_{\mathrm{ON}}$ - metalo oksido lauko tranzistoriaus laižiojo kanalo elektrinę varža, kai kanalas atviras;

$t_{0}$ - pradinis laiko momentas;

$U$ - elektros itampa;

$U_{\mathrm{Ast}}-$ pjūklinès įtampos amplitudè;

$U_{\text {in }}, U_{1}-$ išèjimo ịtampa;

$U_{\text {iš }}, U_{2}-$ iejjimo ịtampa;

$U_{\mathrm{sp}}$ - grį̌žtamojo transformatoriaus magnetinio sklaidos srauto kuriamas viršįtampis;

$\eta$ - naudingumo koeficientas;

$\Phi$ - pagrindinis magnetinis srautas transformatoriaus magnetolaidyje;

$\Phi_{\mathrm{S}}$ - skaidos magnetinis srautas transformatoriaus magnetolaidyje;

$\omega-$ kampinis dažnis $(2 \pi f), \mathrm{rad} / \mathrm{s}$.

\section{Santrumpos}

FE - fotovoltinis elementas;

IGBT - bipoliarinis tranzistorius su izoliuota užtūra (angl. Insulated Gate Bipolar

Tranzistor);

IPM - impulso pločio moduliacija;

PI - proporcinis integralinis;

PID - proporcinis integralinis diferencialinis;

PR - proporcinis rezonansinis;

SIPM - sinusinè impulsų pločio moduliacija. 


\section{Turinys}

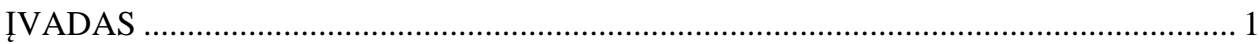

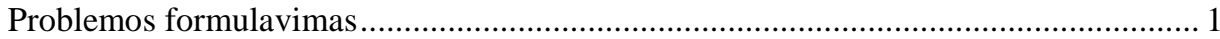

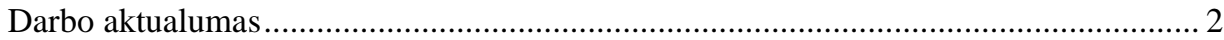

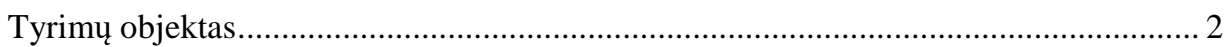

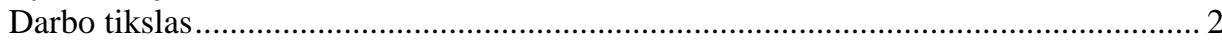

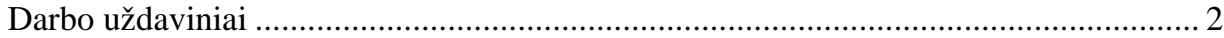

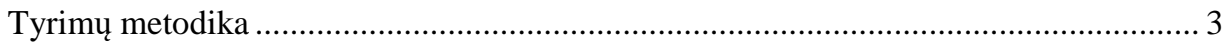

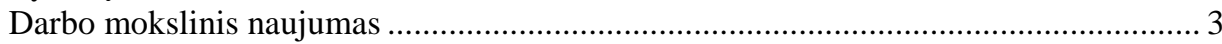

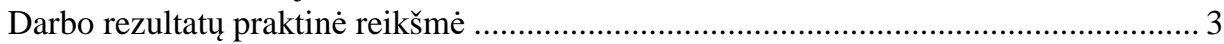

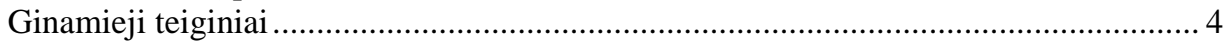

Darbo rezultatu aprobavimas................................................................................ 4

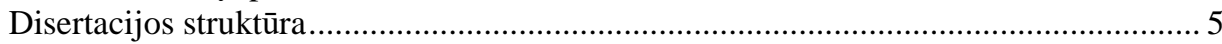

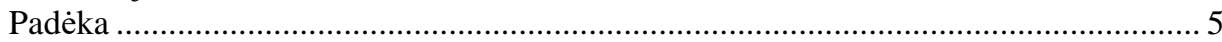

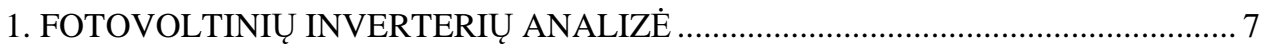

1.1. Fotovoltinių inverterių klasifikavimas............................................................... 7

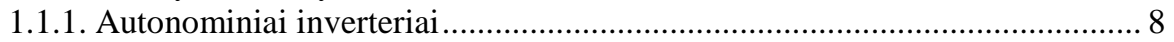

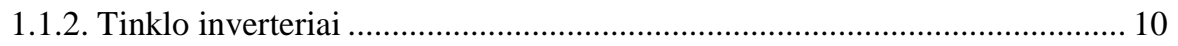

1.2. Fotovoltinių mikroinverterių ir jų srovès valdymo sistemų analizė ...................... 12

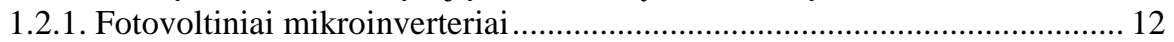

1.2.2. Fotovoltinių mikroinverterių srovės valdymo sistemos ................................. 16

1.3. Nuolatinès įtampos keitiklių fotovoltiniams mikroinverteriams analizė ................ 18

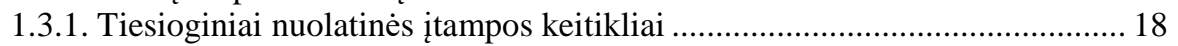

1.3.2. Grižtamieji nuolatinès ịtampos keitikliai ................................................... 21

1.4. Pirmojo skyriaus išvados ir disertacijos uždavinių formulavimas........................ 26 


\section{ENERGETIŠKAI EFEKTYVAUS FOTOVOLTINIO MIKROINVERTERIO}

2.1. Klasikinis nuolatinès įtampos grịžtamasis keitiklis su aktyviąja viršitampio gesinimo grandine

2.2. Nuolatinès ịtampos grịžtamasis keitiklis su alternatyvia aktyvine viršitampio gesinimo grandine.

2.2.1. Keitiklio su alternatyvia aktyviąa viršitampio gesinimo grandine elektrinè schema ir veikimo principas

2.2.2. Keitiklio su alternatyvia aktyviaja viršitampio gesinimo grandine

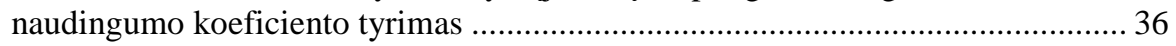

2.3. Dviejų raktų nuolatinès įtampos grį̌tamasis keitiklis ............................................ 40 2.3.1. Dviejų raktų nuolatinès įtampos grįžtamojo keitiklio elektrinè schema ir veikimo principas

2.3.2. Dviejų raktų nuolatinès įtampos grižtamojo keitiklio naudingumo koeficiento tyrimas

2.4. Vienos pakopos mikroinverteris, sudarytas iš dviejų raktų grižtamųjų keitikliu......

2.4.1. Vienos pakopos mikroinverterio, sudaryto iš dviejų raktų grịžtamujų keitikliu, elektrinè schema ir veikimo principas

2.4.2. Vienos pakopos mikroinverterio, sudaryto iš dviejų raktų grižtamujų keitiklių, naudingumo koeficiento tyrimas

3. MIKROINVERTERIO VALDYMO SISTEMOS KŪRIMAS IR ELEMENTŲ PARAMETRŲ İTAKOS MIKROINVERTERIO ENERGETINIAM

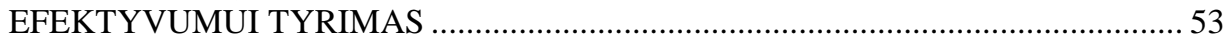

3.1. Mikroinverterio srovès valdymo sistemos kūrimas ir tyrimas............................... 54

3.1.1. Mikroinverterio srovès valdymo sistema su proporciniu

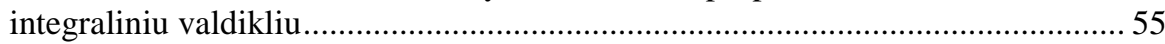

3.1.2. Proporcinis integruojantis valdiklis su keičiamu laike proporciniu koeficientu

3.1.3. Mikroinverterio srovès valdymo sistemos su proporciniu integraliniu valdikliu su keičiamu laike proporciniu koeficientu tyrimas............... 64

3.2. Elementų parametrų įtakos mikroinverterio energetiniam efektyvumui tyrimas 68

3.3. Grịžtamojo transformatoriaus vienos pakopos mikroinverteriui tobulinimas 76

3.3.1. Magnetinio srauto sklaidos susidarymo priežastys ...................................... 76

3.3.2. Grị̌tamojo transformatoriaus magnetinio srauto sklaidos reiškinių

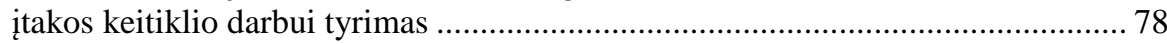

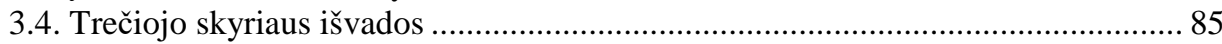

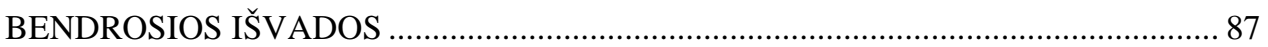

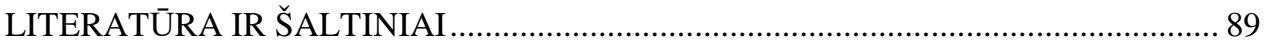


AUTORIAUS MOKSLINIŲ PUBLIKACIJŲ DISERTACIJOS TEMA

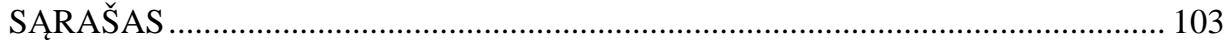

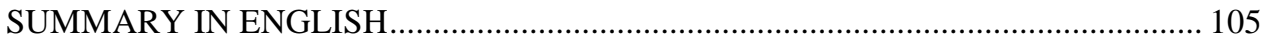

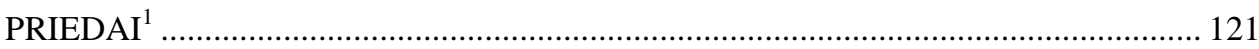

A priedas. Disertacijos autoriaus sąžiningumo deklaracija ........................................ 123

B priedas. Bendraautorių sutikimai teikti publikacijų medžiagą disertacijoje............. 124

C priedas. Autoriaus mokslinių publikacijų disertacijos tema kopijos........................ 132

${ }^{1}$ Priedai pateikiami pridetoje kompaktinèje plokštelèje. 



\section{Contents}

INTROUCTION

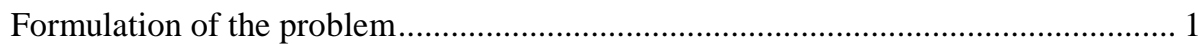

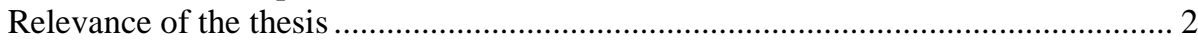

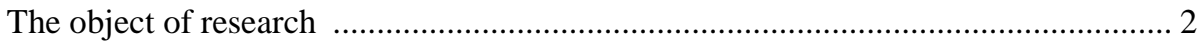

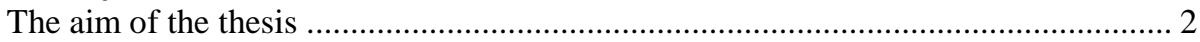

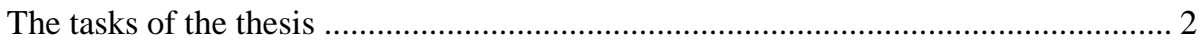

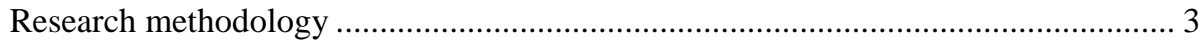

Scientific novelty of the thesis .............................................................................. 3

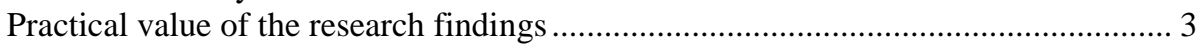

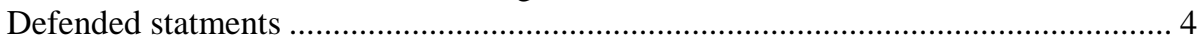

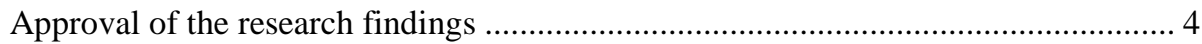

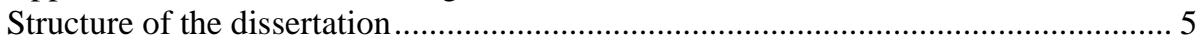

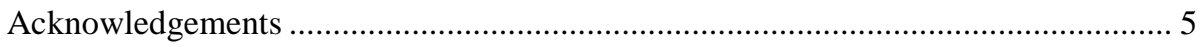

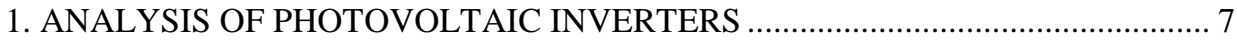

1.1. Classification of photovoltaic inverters ....................................................... 7

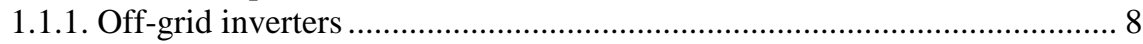

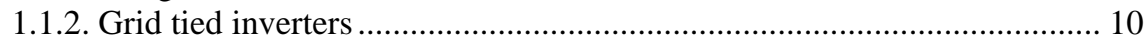

1.2. Analysis of photovoltaic microinverters and their current control systems........ 12

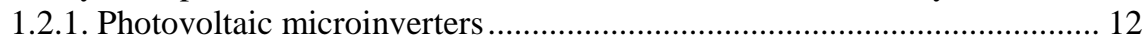

1.2.2. Current control systems of photovoltaic microinverters ........................... 16

1.3. Analysis of $\mathrm{DC} / \mathrm{DC}$ voltage converters for photovoltaic microinverters............ 18

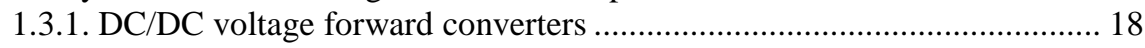

1.3.2. DC/DC voltage flyback converters .......................................................... 21

1.4. Conclusions of the first chapter and formulation of the dissertation tasks ......... 26

2. DEVELOPMENT AND INVESTIGATION OF THE POWER STAGE OF AN ENERGY EFFICIENT PHOTOVOLTAIC MICROINVERTER 
2.1. Classic DC/DC voltage flyback converter with active surge suppression circuit

2.2. Classic DC/DC voltage flyback converter with an alternative active surge suppression circuit

2.2.1. Circuit diagram and operating principle of a converter with an alternative active surge suppression circuit

2.2.2. Efficiency investigation of a converter with an alternative active surge suppression circuit.

2.3. Two-switch DC/DC voltage flyback converter

2.3.1. Circuit diagram and operating principle of a two-switch DC/DC voltage flyback converter

2.3.2. Investigation of the efficiency of a two-switch DC/DC voltage flyback converter

2.4. Single stage photovoltaic microinverter based on couple of two-switch DC/DC flyback converters

2.4.1. Circuit diagram and operating principle of a single stage photovoltaic microinverter based on couple of two-switch DC/DC flyback converters.

2.4.2. Investigation of the efficiency of a single stage photovoltaic microinverter based on couple of two-switch DC/DC flyback converters ......... 48

2.5. Conclusions of the second chapter 51

3. DEVELOPMENT OF A MICROINVERTER CONTROL SYSTEM AND INVESTIGATION OF THE INFLUENCE OF ELEMENT PARAMETERS ON THE ENERGY EFFICIENCY OF A MICROINVERTER ............................ 53

3.1. Development and investigation of a microinverter current control system ........ 54

3.1.1. Microinverter control system based on proportional-integral controller.

3.1.2. Proportional-integral controller with the time-varying proportional constant

3.1.3. Investigation of the microinverter curent control system based on the proportional-integral controller with the the time-varying proportional constant

3.2. Investigation of the influence of element parameters on the energy efficiency of a microinverter. 68

3.3. Improvement of a flyback transformer of a single - stage microinverter .......... 76

3.3.1. Causes of magnetic flux leakage....................................................... 76

3.3.2. Investigation of the influence of flyback transformer leakage flux phenomena on the converter operation 78

3.4. Conclusions of the third chapter

GENERAL CONCLUSIONS 87

REFERENCES 89

LIST OF SCIENTIFIC PUBLICATIONS OF THE AUTHOR ON THE TOPIC OF THE DISSERTATION. 
ANNEXES $^{2}$

Annex A. Author's declaration of ademic integrity ............................................ 123

Annex B. Co-authors' agreements to present publications material in the

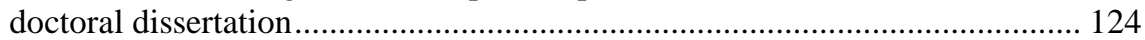

Annex C. Copies of scientific publications of the author on the topic of the dissertation.

${ }^{2}$ The annexes are supplied in the enclosed compact disc. 



\section{Ivadas}

\section{Problemos formulavimas}

Šiuo metu vis plačiau naudojami mažos galios fotovoltiniai inverteriai, skirti vienam standartiniam fotovoltiniam moduliui, kurio maksimali tiekiama galia yra apie $250 \mathrm{~W}$. Tokie inverteriai yra vadinami fotovoltiniais mikroinverteriais. Pagrindinis fotovoltinių mikroinverterių pranašumas yra tas, kad keičiant nuolatinę fotovoltinę ịtampą i kintamają, maksimalios galios režimas yra garantuojamas individualiai kiekvienam fotovoltiniam moduliui.

Fotovoltiniai mikroinverteriai turi ir trūkumų. Pagrindinis trūkumas yra žemesnis energetinis efektyvumas lyginant su inverterių, skirtu aptarnauti daugelị fotovoltinių modulių. Šio trūkumo priežastis - fotovoltinio modulio tiekiama ịtampa yra santykinai žema (apie $30 \mathrm{~V}$ ), todèl būtinas aukštinantysis nuolatinès ịtampos keitiklis, kuris pakeltų ịtampą iki mikroinverterio generuojamos standartinès elektros tinklo ịtampos amplitudès vertès. Nuolatinès itampos keitiklyje yra prarandama dalis energijos, todèl bendras mikroinverterio energetinis efektyvumas sumažèja. Kita problema - netiesiniai mikroinverterio tiekiamos į elektros tinklą srovès iškraipymai.

Apibendrinant, galima suformuluoti šias fotovoltinių mikroinverterių problemas, kurios sprendžiamos disertacijoje: energetinio efektyvumo problema; tiekiamos ị elektros tinklą srovès netiesinių iškraipymų problema. 


\section{Darbo aktualumas}

Tyrimai rodo (Micro-Inverter Market 2020), kad nuo $2018 \mathrm{~m}$. fotovoltinių mikroinverteriu rinka kasmet auga 19,3\% ir 2023 pasieks 5,9 milijardų JAV dolerių. Rinkos augimas iš vienos pusès yra sąlygojamas nuolatinio mikroinverterių tobulinimo, kuris gerina jų parametrus ir mažina kainą, iš kitos pusès, rinka sparčiai auga dèl vis didejjančio naujai įdiegiamų fotovoltinių jègainių kiekio. Todèl tyrimai, leidžiantys kurti tobulesnius fotovoltinius mikroinverterius, pasižyminčius aukštu naudingumo koeficientu ir mažais tiekiamos ị elektros tinklą srovès netiesiniais iškraipymais, yra aktualūs ir turi praktinę vertę.

\section{Tyrimu objektas}

Tyrimų objektas - energetiškai efektyvus fotovoltinis mikroinverteris su sumažintais generuojamos srovès netiesiniais iškraipymais.

\section{Darbo tikslas}

Darbo tikslas - sukurti energetiškai efektyvų vienos pakopos fotovoltinị mikroinverterị ir jo valdiklị tiekiamos ị elektros tinklą srovès valdymui, ištirti mikroinverterị eksperimentiškai bei modeliuojant.

\section{Darbo uždaviniai}

Darbo tikslui pasiekti, sprendžiami šie uždaviniai:

1. Sukurti energetiškai efektyvų nuolatinès įtampos keitikli ir jo pagrindu sukurti vienos pakopos fotovoltinị mikroinverterį.

2. Sukurti mikroinverterio srovès valdymo sistemą ir ją ištirti modeliuojant bei eksperimentiškai.

3. Ištirti sukurto fotovoltinio mikroinverterio elementų parametrų ịtaką mikroinverio naudingumo koeficientui modeliuojant ir eksperimentiškai. 


\section{Tyrimų metodika}

Darbe taikomi analitiniai metodai, modeliavimas ir eksperimentiniai tyrimai. Eksperimentiniai tyrimai atlikti naudojant mikroinverterio bandomaji stendą. Mikroinverterio valdymo algoritmai igyvendinami iterptineje sistemoje su mikrovaldikliu, sukuriant programas $\mathrm{C}$ programavimo kalba. Mikroinverterio modeliavimas atliktas Matlab/Simulink programine įranga.

\section{Darbo mokslinis naujumas}

Rengiant disertaciją buvo gauti šie elektros ir elektronikos inžinerijos mokslui nauji rezultatai:

1. Sukurtas naujas dviejų raktų grižtamasis (angl. flyback) nuolatinès itampos keitiklis vienos pakopos mikroinverteriui, kuris turi aukštesnį naudingumo koeficientą, lyginant su žinomais tokios paskirties įtampos keitikliais.

2. Sukurtas naujas PI tipo valdymo algoritmas su kintančiu laike proporciniu koeficientu mikroinverterio išèjimo srovès valdymui, kuris, lyginant su dažniausiai mikroinverteriuose naudojamu îprastiniu PI reguliatoriumi, leidžia gauti mažesnius tiekiamos ị elektros tinklą srovès netiesinius iškraipymus.

3. Pasiūlytas naujas grižtamojo transformatoriaus mikroinverteriui apvijų išdèstymo būdas „šachmatų lentos“ principu, kuris leidžia gauti mažesnius magnetinio sklaidos srauto reiškinio kuriamus ịtampos išmetimus pirminès transformatoriaus apvijos grandinėje, lyginant su kitais žinomais apvijų išdèstymo būdais.

\section{Darbo rezultatų praktinė reikšmė}

Gauti tyrimų rezultatai gali būti taikomi aukšto energetinio efektyvumo fotovoltiniams mikroinverteriams, skirtiems vienam standartiniam fotovoltiniam moduliui, kurti. 


\section{Ginamieji teiginiai}

1. Sukurto dviejų raktų nuolatinès ịtampos grịžtamojo keitiklio naudingumo koeficientas siekia 0,918 , esant $80 \mathrm{~W}$ apkrovos galiai ir $36 \mathrm{kHz}$ raktų komutavimo dažniui. Gautas naudingumo koeficientas yra 2,3\% didesnis, lyginant su klasikinès topologijos grižtamojo itampos keitiklio naudingumo koeficientu.

2. Valdant mikroinverterio išèjimo srovę tiekiamą ị elektros tinklą sukurtu PI valdikliu su kintančiu laike proporciniu koeficientu, srovès netiesiniai iškraipymai tinkle su neiškraipyta ịtampos forma sumažèja $42 \%$, o tinkle, kurio ịtampa iškraipyta 3-ia ir 5-ta harmonikomis - $22 \%$, lyginant su rezultatais gautais naudojant ịprastinị PI reguliatorių.

3. Pirminès grịžtamojo transformatoriaus apvijos aktyvinès varžos ịtaka mikroinverterio naudingumo koeficientui yra 40 kartų, o ją komutuojančių raktų atvirojo tranzistoriaus varžos - 33 kartus didesnè, lyginant su tų pačių antrinès transformatoriaus apvijos ir joje naudojamų raktų tranzistorių parametrų ịtaka.

4. Grịžtamojo transformatoriaus apvijų išdèstymo būdas pasiūlytuoju „šachmatų lentos“ metodu leidžia sumažinti komutacinių viršịtampių sąlygojamus galios nuostolius ịtampą slopinančioje grandinèje ne mažiau kaip 4,2\%, lyginant su kitais žinomais apvijų išdèstymo metodais, kai tiekiama ị apkrova galia yra $100 \mathrm{~W}$.

\section{Darbo rezultatu aprobavimas}

Disertacijos tema yra atspausdinti 7 moksliniai straipsniai: 5 recenzuojamuose mokslo žurnaluose ir 2 konferencijų darbuose.

Disertacijoje atliktų tyrimų rezultatai buvo pristatyti 10 mokslinių konferencijų: 9 Lietuvoje ir 1 užsienyje:

- 18-oje Lietuvos jaunųų mokslininkų konferencijoje „Mokslas Lietuvos ateitis“, elektronika ir elektrotechnika. 2015 m., Vilniuje;

- Šiaulių universiteto Technologijos ir gamtos mokslų fakulteto 10-je mokslineje konferencijoje „Studentų moksliniai darbai“. 2015 m., Šiauliuose; 
- FTMC Doktorantų konferencijoje „FizTech 2015“. 2015 m., Vilniuje;

- 19-oje Lietuvos jaunujų mokslininkų konferencijoje „Mokslas Lietuvos ateitis“, elektronika ir elektrotechnika. 2016 m., Vilniuje;

- 20-oji tarptautinè konferencija „ELECTRONICS 2016“. 2016 m., Palangoje;

- FTMC Doktorantų konferencijoje „FizTech 2016“. 2016 m., Vilniuje;

- 20-oje Lietuvos jaunųjų mokslininkų konferencijoje „Mokslas Lietuvos ateitis“, elektronika ir elektrotechnika. 2017 m., Vilniuje;

- 21-oji tarptautinè konferencija „ELECTRONICS 2017“. 2017 m., Palangoje;

- 2018 Open Conference of Electrical, „Electronic and Information Sciences (eStream)“. 2018 m., Vilniuje;

- 2018 International Symposium on Advanced Electrical and Communication Technologies (ISAECT), 2018 m., Rabate.

\section{Disertacijos struktūra}

Disertaciją sudaro ịvadas, trys skyriai ir bendrosios išvados. Darbo pabaigoje pateiktas literatūros šaltinių ir autoriaus publikacijų disertacijos tema sąrašas.

Darbo apimtis yra 119 puslapių, neįskaitant priedų, tekste panaudotos 15 numeruotų formulių, 65 paveikslai ir 8 lentelès. Rašant disertaciją buvo panaudoti 167 literatūros šaltiniai.

\section{Padèka}

Autorius dèkoja savo moksliniam vadovui prof. dr. Algirdui Baškiui už suteiktą galimybę tobulèti, vertingas konsultacijas ir motyvaciją.

Ačiū kolegoms Martynui Šapurov, Vytautui Bleizgiui ir Andriui Platakiui už vertingas konsultacijas, pastabas ir suteiktą pagalbą doktorantūros studijų metu. 
Dèkoju Valstybiniam mokslinių tyrimų institutui Fizinių ir technologijos mokslų centrui ir Šiaulių universitetui už galimybę studijuoti, tobulèti ir vykdyti mokslinę veiklą.

Didžiausia padèka skiriama žmonai Vaidai, dukrai Monikai už didelị palaikymą ir motyvaciją. Tai pat dèkoju tèvams Juditai ir Vytautui ir broliui Vytautui. 


\section{Fotovoltinių inverterių analizè}

Skyriuje analizuojami fotovoltinių inverterių tipai ir savybès. Plačiai nagrinėjami mikroinverteriai, jų energetinis efektyvumas, išèjimo srovės kokybė ir jos valdymo sistemos. Pateikiamos pirmojo skyriaus išvados ir formuluojami disertacijos uždaviniai.

Skyriaus tematika paskelbtas autoriaus straipsnis (Bielskis, Šapurov, Platakis 2016b).

\subsection{Fotovoltinių inverterių klasifikavimas}

Fotovoltiniai elementai generuoja nuolatinę įtampą, tuo tarpu elektros prietaisai yra pritaikyti maitinimui kintamaja ịtampa. Todèl fotovoltinių modulių, kurie yra sudaryti iš daugelio fotovoltinių elementų, energija negali būti tiesiogiai panaudota (Surapaneni et al. 2015; Feng et al. 2018; Jiang et al. 2012; Melo et al. 2018; Öztürk et al. 2018; Zhang 2013). Norint panaudoti fotovoltinę energiją, būtina nuolatinę elektros srovę pakeisti i kintamąją (Gagrica et al. 2015; Hu et al. 2013.). Šiam tikslui igyvendinti reikalingas galios elektronikos prietaisas - inverteris (Bleizgys 2012; Platakis 2014), kuris keičia nuolatinę fotovoltinę įtampą ị kintamają. Yra dvi fotovoltinių inverterių grupès: 
1. Autonominiai inverteriai (Kharitonov et al. 2012; Firdaus et al. 2018; Seliga et al. 2014), kurie generuoja elektros energiją energetineje saloje, atsietoje nuo centralizuoto elektros tiekimo tinklo.

2. Tinklo inverteriai (Sun 2011; Azli 2008; Libin 2015), kurie tiekia elektros energiją i centralizuotą elektros tinklą.

\subsubsection{Autonominiai inverteriai}

Fotovoltinès sistemos su autonominiu inverteriu struktūrinè schema pateikta 1.1 paveiksle.

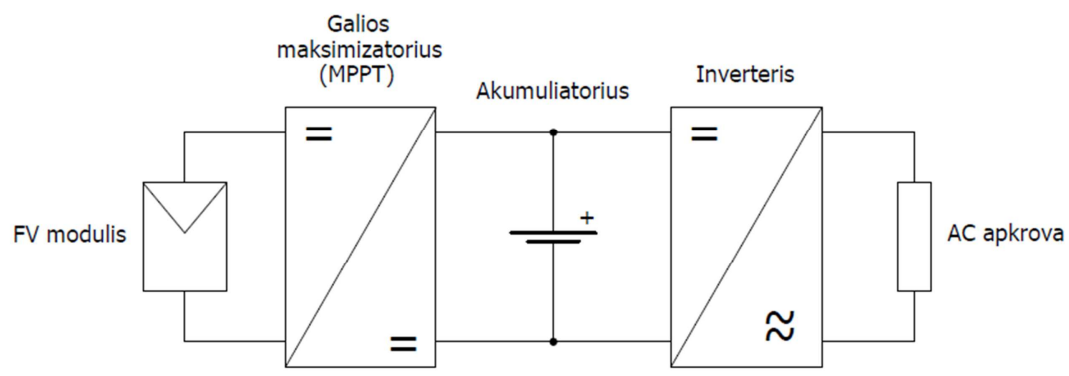

1.1 pav. Autonominès fotovoltinès sistemos struktūrinè schema

Fig. 1.1. Block diagram of autonomous photovoltaic system

Autonominèje fotovoltinèje sistemoje inverteris tiekia elektros energiją $\mathfrak{i}$ tinklą nesusietą su centralizuotu elektros tinklu, t. y. dirba autonomiškai (Timofeeva 2010; Paridari 2013). Tokioje sistemoje inverterio struktūra yra paprastesné, nes nereikia sinchronizacijos su elektros tinklu. Kita vertus, tokioms autonominèms sistemoms reikalingas galios balastas, gebantis kompensuoti momentini galios deficitą tuomet, kai fotovoltinès elektros energijos gaminama per mažai apkrovai aptarnauti arba esant energijos pertekliui, kai daugiau fotovoltinès energijos yra pagaminama negu suvartojama - kaupti perteklių (Liu et al. 2015; Saxena et al. 2017). Śio elektros energijos balasto funkciją atlieka akumuliatorių baterija.

Kad gauti maksimalią ịmanomą galią iš fotovoltinių modulių - inverteris paprastai turi galios maksimizatoriu (angl. MPPT - maximum power point tracking) - specialią inverterio imamos iš fotovoltinių modulių srovès valdymo sistemą (Pikutis 2015; Sher et al. 2015; Ryu et al. 2018; Dong et al. 2015; Morales-Caporal et al. 2016; Haji et al. 2018; Uprety et al. 2017). Ši sistema valdo fotovoltinio modulio apkrovos srovę tokiu būdu, kad išmatuota galia tiekiama iš fotovoltinio modulio arba grupès sujungtų modulių būtu maksimali. 
Keičiantis fotovoltinio modulio darbo sąlygoms (saulès spinduliuotès intensyvumui, modulio padéčiai saulès atžvilgiu ir t.t.), keičiasi ir fotovoltinio modulio apkrovos srove, kuriai esant gaunama iš modulio galia yra maksimali (1.2 pav.).

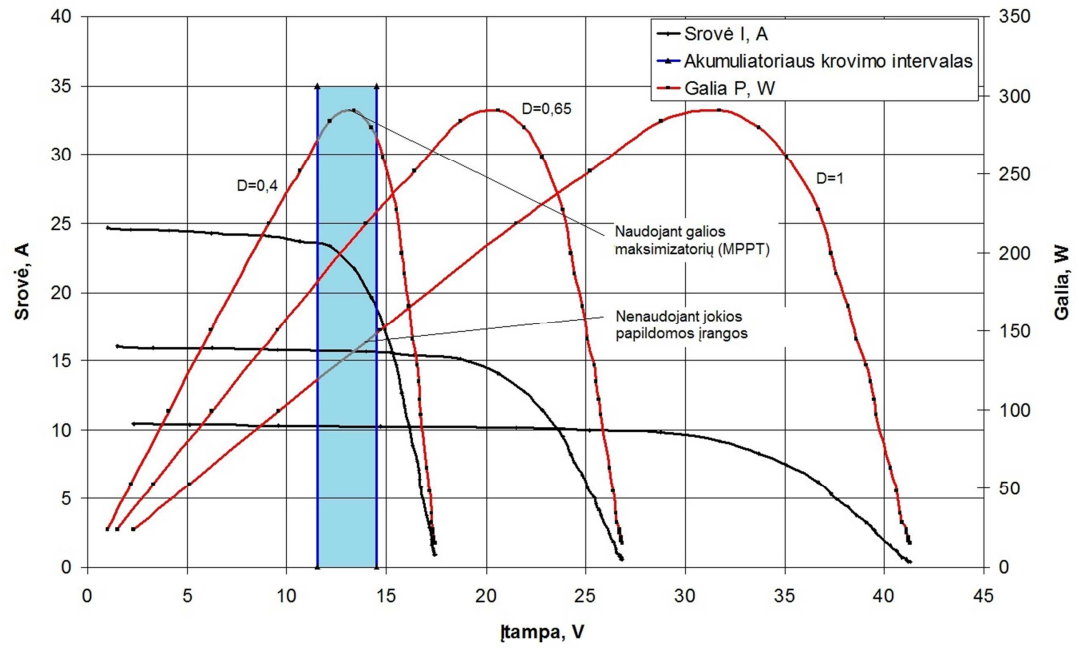

1.2 pav Maksimalios galios sekimo principas

Fig. 1.2. Maximum power tracking principle

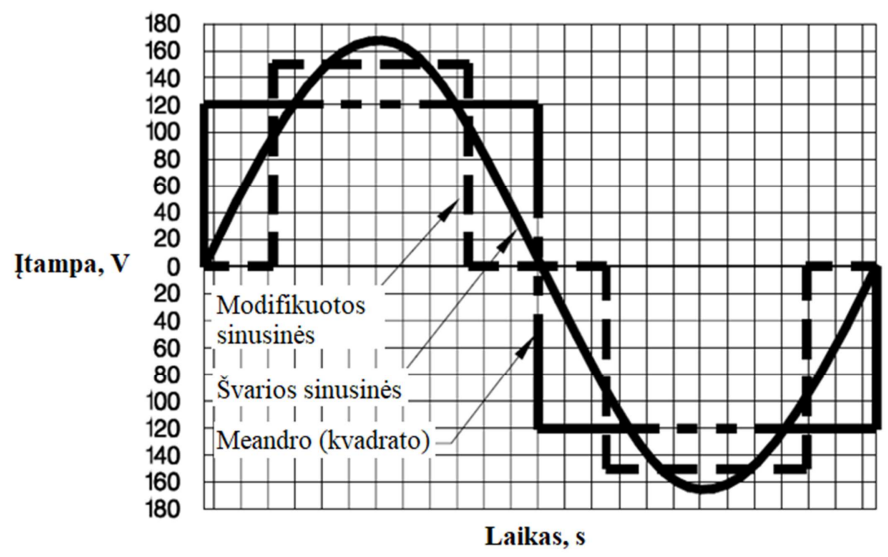

1.3 pav. Autonominių inverterių išęjimo ịtampos formos

Fig. 1.3. Typical autonomous inverter output voltage shapes 
Priklausomai nuo kintamosios įtampos formavimo būdo išskiriami trijų tipų inverteriai:

1. Inverteriai formuojantys meandro (kvadrato) formos ịtampą (1.3 pav.) (Khluabwannarat et al. 2007; Wang et al. 2016; Cui et al. 2008).

2. Inverteriai formuojantys modifikuotos sinuso formos įtampą (angl. modified sine wave). Šių inverterių itampos forma yra laiptuota (1.3 pav.) (Acharya 2014; Namin et al. 2018; Sheng 2013).

3. Sinuso formos itampą formuojantys inverteriai (angl. pure sine wave). Tokio tipo inverteriai generuoją sinusinę išejimo įtampą, naudojant sinusinį IPM metodą (1.3 pav.) (Haider et al. 2012; Chowdhury et al. 2013; Gulame et al. 2018).

\subsubsection{Tinklo inverteriai}

Tinklo inverterių tarpe šiuo metu labiausiai yra paplitę centriniai inverteriai (1.4 pav. a). Jie yra naudojami didelès galios fotovoltinèse elektrinèse, kurių galia yra nuo $3 \mathrm{~kW}$ iki $1 \mathrm{MW}$. Šiose sistemose fotovoltiniai moduliai sujungiami nuosekliai tam, kad gauti aukštą 500-800 V nuolatinę ịtampą. Galiai didinti tokių nuosekliai sujungtų modulių grupès sujungiamos lygiagrečiai. Šio tipo inverteriai labai išpopuliarèjo atsiradus IGBT (angl. insulate gate bipolar transistor) tranzistoriams, kurie naudojami inverterio išejimo laipsnyje. Pagrindiniai centrinių inverterių trūkumai:

1. Inverterio grandinès nèra izoliuotos nuo elektros tinklo, todèl būtina naudoti aukštos įtampos gerai izoliuotus kabelius tarp fotovoltinių modulių ir keitiklio, fotovoltiniai moduliai turi būti patikimai izžeminti (Pezeshki et al. 2014, Agamy et al. 2013).

2. Nèra galimybès atskirai igyvendinti maksimalios galios sekimo kiekvienam fotovoltiniam moduliui, todèl atskiri moduliai veikia ne optimaliu režimu ir iš elektrinès nèra išgaunama maksimali galima energija.

3. Jungiant fotovoltinius modulius nuosekliai, dèl jų voltamperinių charakteristikų sklaidos mažeja bendras nuosekliai sujungtų modulių naudingumo koeficientas (Šályet al. 2015; BastidasRodríguez et al. 2015; Rana et al. 2018); 
4. Atskirų nuosekliai sujungtų fotoelektrinių modulių grupių tarpusavio išrišimui naudojami nuosekliai ijungti diodai, kurie papildomai didina energijos nuostolius.

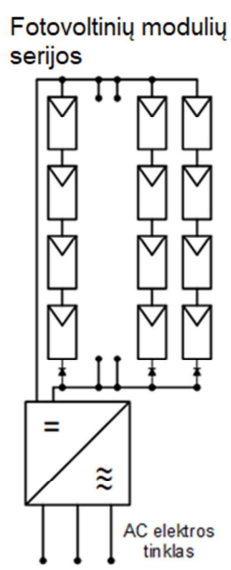

a)

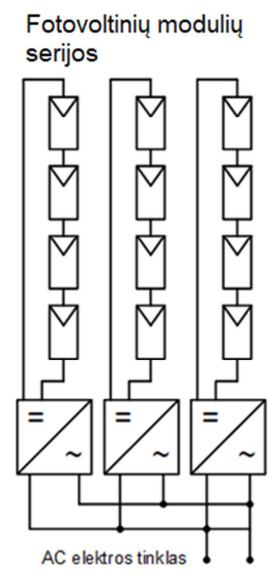

b)

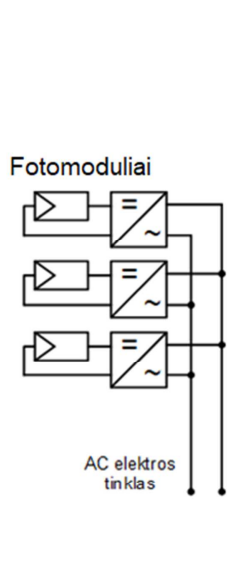

c)

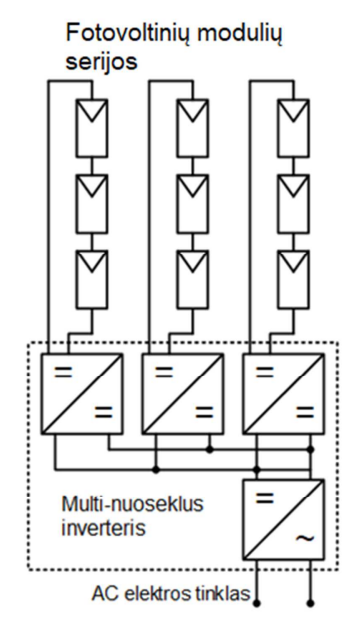

d)

1.4 pav. Tinklo inverteriai: a) centrinis inverteris; b) nuoseklieji inverteriai;

c) mikroinverteriai; d) multi nuoseklieji inverteriai

Fig. 1.4. Grid-tied inverters: a) central inverter; b) series inverters; c) microinverters; d) multi-series inverters

Nuoseklieji inverteriai (1.4 pav. b) - tai inverteriai, naudojami fotovoltinèse elektrinèse kiekvienai nuosekliai sujungtai fotoelektrinių modulių grupei. Tokių inverteriu galios diapazonas yra nuo 0,4 iki $2 \mathrm{~kW}$ galios. Naudojant nuosekliuosius inverterius, nuosekliai sujungtos fotoelektrinių modulių grupés itampa yra nuo 320 iki $350 \mathrm{~V}$, kai inverteris elektra tiekia ị vienfazi elektros tinklą ir nuo 600 iki $750 \mathrm{~V}$, kai elektra yra tiekiama ị trifazị tinklą.

Nuosekliujų inverterių privalumai, lyginant su centriniais inverteriais:

1. Nereikia naudoti nuosekliai ijungtų diodų.

2. Kiekvienai nuosekliai sujungtai fotovoltinių modulių grupei galima atskirai įdiegti maksimalios galios sekimo funkciją.

3. Kadangi yra naudojami keli inverteriai, padideja bendras sistemos patikimumas.

Kitas naudojamas inverterių tipas multi nuoseklieji inverteriai. Fotovoltinèje elektrinèje su tokiais inverteriais atskirose fotovoltinių modulių grupèse moduliai jungiami nuosekliai (1.4 pav. d). Tokio tipo elektrinèje kiekvienai fotovoltinių modulių grupei naudojamas atskiras nuolatinès įtampos keitiklis, kurių tiekiama ịtampa paduodama ì bendrą inverterị. Šio tipo topologijos 
privalumai yra tai, kad kiekvienai fotovoltinių modulių grupei yra sekama maksimali galia, kas leidžia gauti didesni jègainès naudingumo koeficientą. Trūkumas yra tai, kad sekamas visos nuosekliai sujungtų modulių grupès maksimalios galios taškas. Kadangi fotovoltinių modulių parametrai turi sklaidą ir moduliai gali dirbti nevienodomis sąlygomis, jų individualus maksimalios galios taškas yra skirtingas, todèl tokioje jègainèje nebus išgaunama maksimali galima energija.

Daugeja fotovoltinių elektrinių, kur kiekvienam fotovoltiniam moduliui naudojamas individualus inverteris (1.4 pav. c). Kadangi tokio inverterio galia yra maža - nuo 50 iki $400 \mathrm{~W}$, toks inverteris vadinamas mikroinverteriu (angl. microinverter) Pagrindinis tokio sprendimo privalumas tas, kad kiekvienas fotovoltinis modulis turi savo mikroinverteri, todèl kiekvienam fotovoltiniam moduliui gali būti sekama maksimali galia ir iš modulio paimama maksimali galima energija. (Öztürk et al. 2015). Kitas privalumas yra tai, kad tokia sistema yra patikima, nes sugedus mikroinverteriui energija nebus tiekiama tik iš vieno fotovoltinio modulio. Tokios sistemos turi ir trūkumų - mikroinverteryje reikalinga ịtampos aukštinimo pakopa, dèl kurios gaunami papildomi energijos nuostoliai (Cha et al. 2015). Jègainė su daugeliu mažos galios inverterių yra brangesnè, nei turinti vieną ar kelis galingesnius inverterius. Tačiau mikroinverteriai pasižymi dideliu integralumu.

\subsection{Fotovoltinių mikroinverterių ir jų srovès valdymo sistemų analizè}

Mikroinverteriai taikytini, kai reikia integruoti fotoelektrinių modulius dirbančius skirtingose sąlygose arba turinčius didelę elektrinių charakteristikų sklaidą. Jie tinka integruoti i išmaniąsias elektros tinklo sistemas, taip pat yra nepakeičiami mažose kelių šimtų vatų fotovoltinèse elektrinèse, kurių kiekis pastaruoju metu sparčiai didèja.

\subsubsection{Fotovoltiniai mikroinverteriai}

Fotovoltinị tinklo mikroinverterị dažniausiai sudaro du pagrindiniai funkciniai mazgai: keitiklis ir inverteris. Keitiklis santykinai žemą kelių dešimčių voltų fotovoltinio modulio nuolatinę įtampą paaukština iki vertès artimos elektros tinklo, ị kurị bus tiekiama energija, kintamosios ịtampos amplitudès vertès. Dalyje mikroinverterių ši keitiklinė dalis, išèjime suformuoja aukštos ịtampos sinuso formos pusperiodžius (Causo et al. 2013; Mohammadi et al. 2015; Minjie et al. 2013; Jianqiang et al. 2009; Woo-Jun et al. 2017; Sukesh, et al. 2015; Xue 
et al. 2010; Erickson et al 2016; Meneses et al. 2012; Yan, T.; et al. 2014; Li et al. 2002; Gu et al. 2013; Thang et al. 2014; Edwin at al. 2014; Liu et al. 2015). Inverteris - funkcinis mazgas nuolatinę ịtampą keičiantis ị kintamają. Šio mazgo darbas turi būti sinchronizuojamas su elektros tinklu, i kuri mikroinverteris tiekia energiją. Inverteris turi pilno (1.5 pav. a) arba pusès (1.5 pav. b) H tiltelio grandyną (angl. $H$ bridge), kuri sudaro atitinkamai 4 arba 2 aukštos įtampos tranzistoriniai raktai (Samundeeswari et al. 2017; Nimmi et al. 2018; Raghavendra 2015; Aalami et al. 2018). Pilno tiltelio inverteriai sudaryti iš keturių Q1-Q4 tranzistorinių raktų (1.5 pav. a). Inverterio raktai, naudojant sinusini IPM metodą, formuoja sinuso formos išẻjimo ịtampą. Raktai yra valdomi taip, kad kai atviri Q1 ir Q4, Q2 ir Q3 yra uždari. Kai atviri Q2 ir Q3 tada uždari turi būti Q1 ir Q4. Rečiau sutinkami pusès tiltelio inverteriai (1.5 pav. b), kurie naudojami mažos galios mikroinverteriuose (Ryu et al. 2016; Zhang et al. 2016). Jų valdymas yra paprastesnis, nes vietoj keturių raktų valdyti reikia tik du raktus. Tačiau norint inverterio išejjime gauti tokios pat amplitudès įtampą, keitiklio tiekiama įtampa $U$ turi būti dvigubai aukštesnè. Taip yra todèl, kad pakeitus vieną tiltelio petị, kuri sudaro raktai Q3 ir Q4 kondensatoriais C1 $\mathrm{C} 2$, kondensatoriai sudaro įtampos dalikli, t. y. ant kiekvieno kondensatoriaus krenta pusè maitinimo šaltinio įtampos $U / 2$.

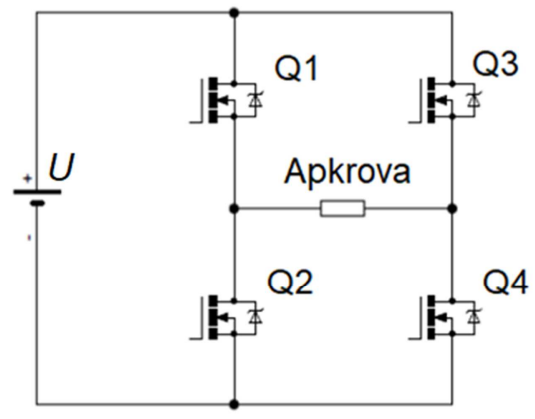

a)

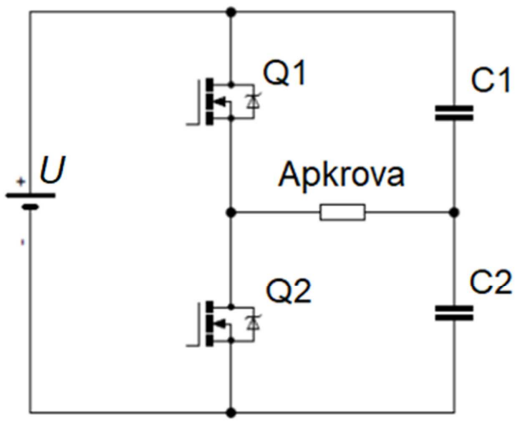

b)

1.5 pav. Inverterių elektrinès schemos: a) pilno tiltelio schema; b) pusès tiltelio schema

Fig. 1.5. Circuit diagrams of inverters: a) full bridge inverter; b) half bridge inverter

Energijos nuostoliai inverterio tranzistorinių raktuose priklauso nuo jų komutavimo dažnio ir nuo atviro tranzistoriaus vidinès varžos.

Mikroinverteriai pagal savo specifiką yra skirstomi ị vieno (Lai et al. 2014) ir dviejų (Lopez-Santos et al. 2015) pakopų:

1. Vienos pakopos (1.6 pav.) mikroinverteriu specifika yra ta, kad jame keitiklis, naudojant IPM metodą, išejime suformuoja sinuso formos pusperiodžius, kurių amplitudė yra artima tinklo, ị kurị yra tiekiama energija, amplitudei. Inverteris sinuso formos 
pusperiodžius paverčia i sinuso formos įtampą. Šiuo atveju inverterio tranzistorinių raktų persijungimo dažnis yra žemas, lygus elektros tinklo ịtampos dažniui, todèl galios nuostolius inverteryje sąlygoja tik atvirojo tranzistoriaus galios nuostoliai. Taip pat vienos pakopos mikroinverteri sudaro santykinai nedidelis kiekis elektronikos komponentų, kuriuose išsiskiria galios nuostoliai, todèl šio tipo mikroinverteriai pasižymi aukštu naudingumo koeficientu (Lai et al. 2014). Jie paprastai yra taikomi vienfazei itampai formuoti.

2. Dviejų pakopu mikroinverteryje (1.7 pav.) kintama ịtampa yra formuojama dviem etapais. Pirmu etapu fotovoltinio modulio įtampa ịtampos aukštinimo keitikliu paaukštinama iki vertès artimos elektros tinklo ịtampos amplitudei. Antruoju etapu nuolatinè ịtampa, naudojant sinusinès impulsų pločio moduliacijos metodą SIPM (angl. SPWM - sine pulse width modulation), inverteriu keičiama i kintamają (Vongkoon et al. 2019).

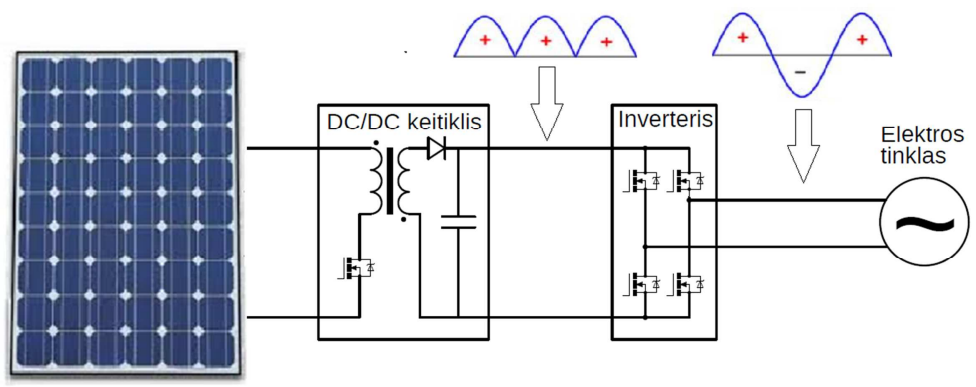

1.6 pav. Vienos pakopos grižtamasis mikroinverteris

Fig. 1.6. One stage Flyback Microinverter

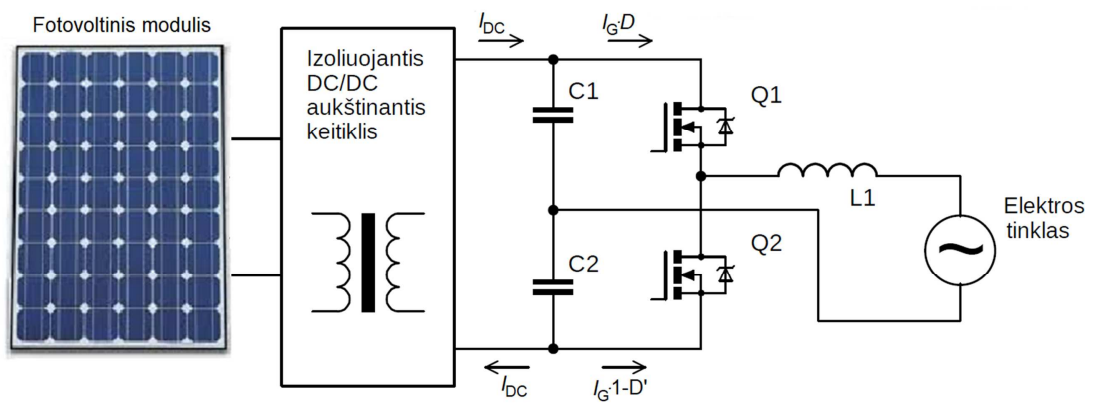

1.7 pav. Dviejų pakopų mikroinverteris (Vongkoon et al. 2019)

Fig. 1.7. Two stage microinverter (Vongkoon et al. 2019) 
Dalyje publikacijų pristatomi taip vadinami grižtamieji (angl. Flyback) vienos pakopos mikroinverteriai, kurie savo sudètyje neturi ịprasto $\mathrm{H}$ tiltelio (1.8 ir 1.9 pav.) (Hu et al. 2013; Hasan et al. 2016; Sukesh et al 2014; Mukherjee et al. 2013; Zhang et al. 2013). Juose kintamoji išèjimo ịtampa iš keitiklio suformuotų įtampos pusperiodžių yra formuojama dvejomis grandinèmis, kiekvieną iš kurių sudaro nuosekliai sujungti tranzistorinis raktas ir diodas (D3 ir Q3, D4 ir Q4, 1.8 pav.) arba du nuosekliai sujungti tranzistoriniai raktai (Q2 ir Q4, Q3 ir Q5, 1.9 pav.) (Bhattacharjee et al. 2020; Alluhaybi et al. 2020). Mikroinverteryje pateiktame 1.8 paveiksle teigiamas įtampos pusperiodis ị tinklą generuojamas atidarant raktą Q3 (raktas Q4 uždaras), neigiamas - atidarant raktą Q4 (raktas Q3 uždaras). Tokio tipo mikroinverteriui reikalingas transformatorius, turintis apviją su vidurio tašku.

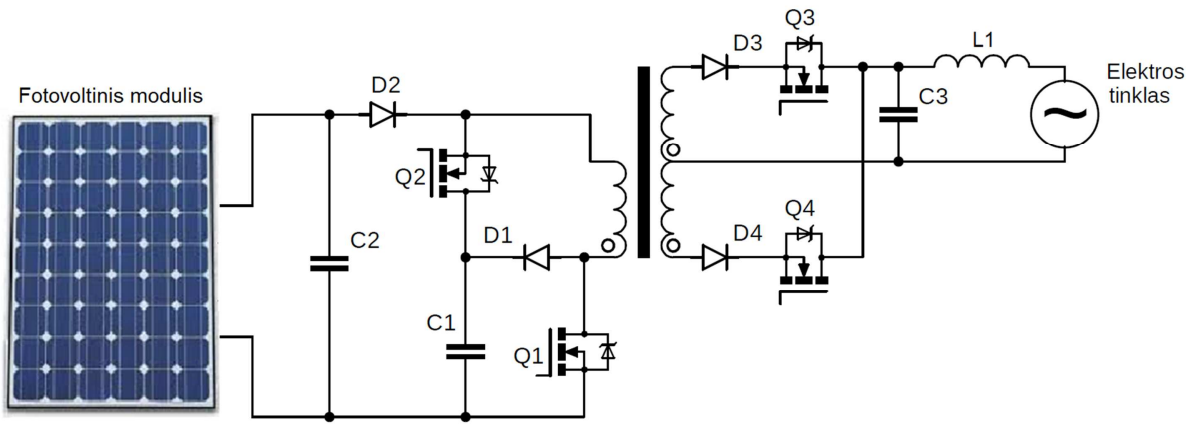

1.8 pav. Vienos pakopos grižtamasis mikroinverteris nenaudojantis $\mathrm{H}$ tiltelio

Fig. 1.8. One stage flyback microinverter without a H-bridge

Mikroinverteryje, pateiktame 1.9 paveiksle, kintamosios itampos pusperiodžiai ị tinklą yra tiekiami naudojant universalius raktus, sudarytus iš dviejų lauko tranzistorių, Q2 ir Q4, Q3 ir Q5, sujungtų nuosekliai ištakomis. Šio mikroinverterio specifinè savybè yra ta, kad šie raktai dirba tuo pačiu $60 \mathrm{kHz}$ dažniu kaip ir tranzistorinis raktas Q1, valdomi tuo pačiu SIPM signalu. Teigiamo pusperiodžio ịtampos formavimo metu raktai Q2 ir Q4, kartu su raktu Q1, tik priešinga faze, komutuojami $60 \mathrm{kHz}$ dažniu. Raktai Q3 ir Q5 tuo metu yra uždaryti, Neigiamo pusperiodžio formavimo metu uždaryti yra Q2 ir Q4 raktai, tačiau $60 \mathrm{kHz}$ dažniu, ta pačia faze kaip ir Q1 raktas yra komutuojami raktai Q3 ir Q5. Tokios struktūros mikroinverterio privalumas - mikroinverterio išèjimo grandinejje nenaudojami diodai, kuriuose išsiskiria galios nuostoliai, todèl šio mikroinverterio naudingumo koeficientas yra aukštesnis už 1.8 paveiksle pateikto mikroinverterio.

Didžiausi galios nuostoliai mikroinverteriuose išsiskiria įtampos aukštinimo keitiklyje (Lai et al. 2014; Alluhaybi et al. 2020), kurio naudojimas mikroinverteriuose yra neišvengiamas, nes fotovoltinio modulio tiekiamą įtampą 
būtina paaukštinti iki tinklo ịtampos amplitudès vertès. Galios nuostoliai susidaro mikroinverterio transformatoriaus apvijose dèl jų baigtinès aktyvinės varžos ir keitiklio raktų tranzistoriuose dè jų baigtinès atviro tranzistoriaus varžos bei dèl nuostolių generuojamų tranzistoriaus persijungimo metu (Causo

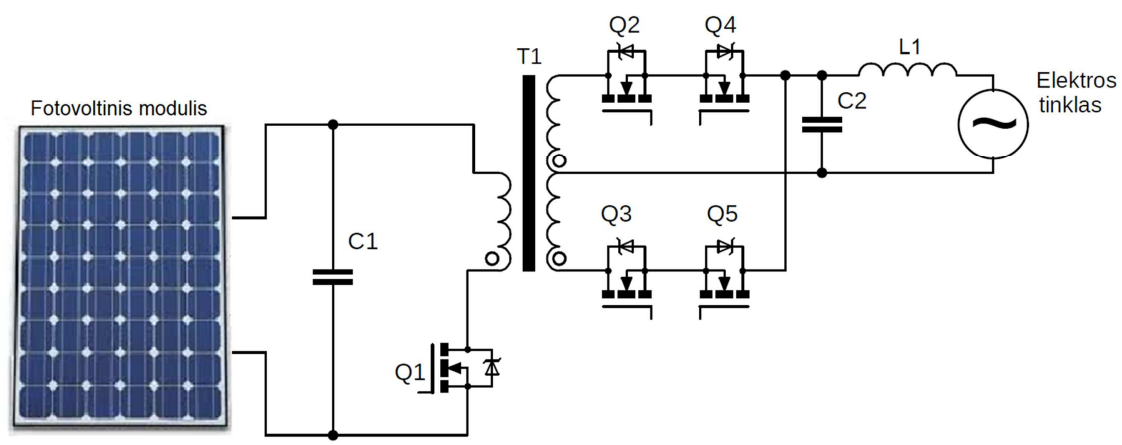

1.9 pav. Vienos pakopos grị̌ztamasis mikroinverteris su universaliais raktais

Fig. 1.9. One stage flyback microinverter with universal switches

et al. 2013; Sukesh et al. 2015; Pezeshki et al. 2014; Rana et al. 2018; Ryu et al. 2016; Zhang et al. 2016; Wu et al. 2017; Bal, S.; Rathore et al. 2016; Sher et al. 2015; Sun 2011; Hansen et al. 2016; Amirahmadi et al. 2014; Surapaneni et al. 2015; Feng et al. 2018; Jiang et al. 2012; Melo et al. 2018; Öztürk et al. 2018; Zhang et al. 2013; Gagrica et al. 2015; Reddy et al. 2015; Hu et al. 2013; Liu et al. 2015; Lai et al. 2014; Bastidas-Rodríguez et al. 2015; Saxena et al. 2017; Cha et al. 2015; Xue et al. 2018; Perrin et al. 2016; Fermin et al. 2015; Šály et al. 2015; Lopez et al. 2017; Schmitz et al. 2017; Min et al. 2018; Öztürk et al. 2015; Lai et al. 2014; Alluhaybi et al. 2020). Norint padidinti naudingumo koeficientą, būtina rasti sprendimus, leidžiančius realizuoti mikroinverterị naudojant minimalų raktų kiekį, su sumažinta atviro rakto tranzistorius varža. Raktų persijungimo metu dèl impulsinio transformatoriaus specifikos saviindukuojasi viršitampiai. Jie sukuria kontūrines sroves mikroinverterio grandinèse, sukeldami papildomus galios nuostolius (Capitaine et al. 2016; Fermin et al. 2015), todèl aktualu tobulinti mikroinverterių impulsinị transformatorių, siekiant mažinti viršįtampius.

\subsubsection{Fotovoltinių mikroinverterių srovės valdymo sistemos}

Šalia mikroinverterių naudingumo koeficiento problemos, augant individualių mažos galios fotovoltinių elektrinių, tiekiančių energiją i elektros tinklą, kiekiui, svarbia problema tampa ir mikroinverterių tiekiamos energijos kokybė. Būtina, 
kad mikroinverteriai negeneruotu ị elektros tinklą aukštesniujų srovès harmonikų, t. y., kad mikroinverterio tiekiamos srovès forma būtų galimai artimesnè sinusui. Todèl yra aktualu atlikti tyrimus ir rasti sprendimus, leidžiančius mažinti mikroinverterio tiekiamos srovès netiesinius iškraipymus (Xin et al. 2017; Kojabadi et al. 2006; Nan et al. 2017; Suzuki et al. 2019; Xia et al. 2017).

Srovès harmonikų mažinimui veiksmingiausia yra naudoti grižtamojo ryšio valdymo sistemą mikroinverterio srovès sinuso dėsnio valdymui. Tam tikslui, $\mathfrak{i}$ mikroinverterio struktūrą turi būti ịterpta automatinio valdymo sistema su grịžtamuoju ryšiu, skirta sinuso dèsnio sekimui. Tokios sistemos paskirtis valdyti mikroinverterio raktus taip, kad mikroinverterio išèjimo srovès forma atkartotų atraminio sinuso signalo formą ir fazę (Rajeev et al. 2018; Motta et al. 2016; Xin et al. 2017; Bayhan et al. 2019; Zha et al. 2017).

Populiariausi valdikliai naudojami tinklo mikroinverterio išèjimo srovei sekti, yra proporcinis integralinis (PI) (Kamil 2019; Hlali et al. 2019) proporcinis integralinis diferencialinis (PID) (Yongjun et al. 2017; Chang-liang et al. 2014) ir proporcinis rezonansinis (PR) (Zhang et al. 2014; Shen et al. 2010) valdikliai. Tačiau gali būti naudojami ir sudetingesni prognozuojantieji (angl. predictive) srovès valdikliai (Kojabadi et al. 2006; Bode et al. 2005).

PI ir PID valdiklių algoritmai pateikti atitinkamai išraiškose:

$$
\begin{gathered}
U(t)=K_{\mathrm{P}} e(t)+K_{\mathrm{I}} \int_{t_{0}}^{t} e(t) \mathrm{d} t \\
U(t)=K_{\mathrm{P}} e(t)+K_{\mathrm{I}} \int_{t_{0}}^{t} e(t) \mathrm{d} t+K_{\mathrm{D}} \frac{\mathrm{d} e(t)}{\mathrm{d} t},
\end{gathered}
$$

čia $U(t)$ valdiklio išějimo signalas, $K_{\mathrm{P}}, K_{\mathrm{I}}, K_{\mathrm{D}}$ - atitinkamai, proporcinis, integralinis ir diferencialinis koeficientai, $e$ - valdymo paklaida, $t_{0}$ yra pradinis laiko momentas.

Šių, gerai žinomų, valdiklių populiarumą lemia lengvas valdiklių diegimas, gerai išplètotos ir paprastos jų parametrų valdomajam objektui priderinimo metodikos. PI ir PID valdiklių trūkumas yra tas, kad jie negali sekti atraminio sinuso signalo, išvengiant nusistovejjusio režimo paklaidos (angl. steady-state error).

PR valdiklio perdavimo funkcija Laplaso erdveje (Zhang et al. 2014):

$$
G_{\mathrm{PR}}(s)=K_{\mathrm{P}}+\frac{2 K_{\mathrm{r}} s}{s^{2}+\omega^{2}},
$$

čia $s$ - Laplaso operatorius, $K_{\mathrm{r}}$ - rezonansinio nario pastovioji, $\omega$ - rezonansinis dažnis. Teoriškai PR valdiklis turi begalini stiprinimą prie rezonansinio dažnio 
(standartiniam elektros tinklui $\omega=314 \mathrm{rad} / \mathrm{s}$ ), todèl teoriškai jis turètų užtikrinti nulinę nusistovèjusio režimo paklaidą tarp faktinès mikroinverterio išèjimo srovès ir nuostato vertès. Tačiau PR valdiklio eksploatavimas yra sudètingas, nes nèra bendrų valdiklio parametrų nustatymo metodų ir tai komplikuoja valdiklio parametrų derinimą jị diegiant (Zhang et al. 2014; Jayalath et al. 2015).

Mikroinverterių srovès valdymui būna naudojami ir prognozuojantieji (angl. predictive) valdikliai. Jų struktūra yra sudètinga lyginant su PI, PID ir PR valdikliais. Prognozuojamo srovès valdiklio algoritmas įvertina kito perjungimo ciklo keitiklio išèjimo srovès vertę, naudodamas ankstesnio ciklo rezultatus, ir leidžia gauti tikslesni srovès formos valdymą. Tačiau prognozuojančiojo srovès valdiklio igyvendinimas yra sudetingas ir reikia gerai suprasti sistemos parametrus (Kojabadi et al. 2006; Bode et al. 2005). Taip pat jo kūrimui būtinas pajègus mikrovaldiklis, galintis realiame laike apdoroti signalus.

Iš atliktos mikroinverterių srovès valdymo sistemų apžvalgos matome, kad norint turèti srovès valdymo sistemą su lengvai diegiamu valdikliu bei gerai išplètota valdiklio parametrų derinimo metodika, tinkamiausi yra naudoti klasikinius PI arba PID valdiklius. Tačiau šie valdikliai neleidžia pasiekti aukšto valdymo tikslumo. Iš kitos pusès, norint tiksliau valdyti srovę, reikètų naudoti sudètingesnius PR arba prognozuojančiuosius valdiklius, bet jų parametrų priderinimas yra komplikuotas.

Reziumuojant galima daryti išvadą, kad aktualu būtų turèti valdiklị, kurio parametrų derinimas būtų panašus ị PI arba PID, tačiau jis leistų gauti tikslesnị srovès valdymą.

\subsection{Nuolatinès ịtampos keitiklių fotovoltiniams mikroinverteriams analizè}

Didžiąą dali galios nuostolių mikroinverteryje sąlygoja nuostoliai nuolatinės itampos keitiklyje (Halder 2018; Yang et al. 2018; Lai et al. 2014; Alluhaybi et al. 2020). Todèl tinkami sprendimai kuriant nuolatinès įtampos keitikli yra vienas iš svarbiausių uždavinių siekiant sukurti aukšto naudingumo koeficiento fotovoltini mikroinverterị. Šiame poskyryje apžvelgsime labiausiai paplitusius aukštinančiuosius nuolatinès įtampos keitiklius, naudojamus mikroinverteriuose.

\subsubsection{Tiesioginiai nuolatinès ịtampos keitikliai}

Paprastai tiesioginiai (angl. forward) nuolatinès įtampos keitikliai yra vientakčiai ir jame naudojamas vienas tranzistorinis raktas. Tokio tiesioginio 
keitiklio elektrinè schema pateikta 1.10 paveiksle. Keitiklio išèjimo efektinè itampa apskaičiuojama formule:

$$
U_{\text {ĭ̌ }}=\frac{\left(U_{\text {in }} \cdot D \cdot \frac{n_{2}}{n_{1}}\right)}{2},
$$

čia $U_{\text {in }}, U_{\text {iš }}$ - įjjimo ir išèjimo įtampos; $D$ - impulsų skvarba; $n_{1}, n_{2}$ - pirminès ir antrinès apvijų vijų skaičius.

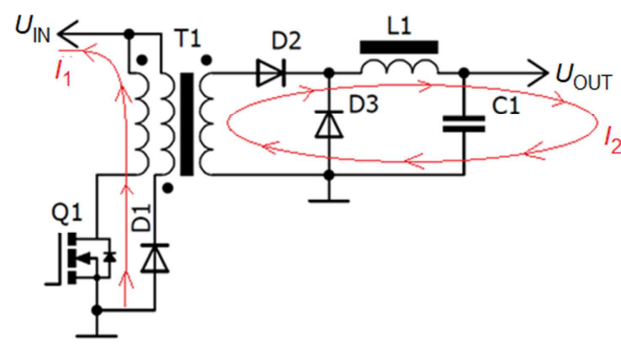

a)

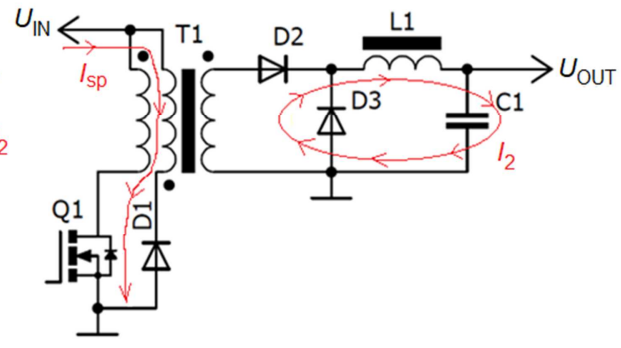

b)

1.10 pav. Vientakčio tiesioginio keitiklio elektrinè schema ir veikimo principas:

a) energijos perdavimas antrinei grandinei, kai rakto tranzistorius Q1 atidarytas;

b) energijos perdavimas antrinei grandinei, kai rakto Q1 tranzistorius uždarytas

Fig. 1.10. Circuit diagram and operation of a typical forward converter: (a) power transfer to the secondary circuit when the transistor of key $\mathrm{Q} 1$ is in state $\mathrm{ON} ; \mathrm{b}$ ) power transfer to the secondary circuit when the transistor of key Q1 is in state OFF

Tiesioginio keitiklio veikimas pagrịstas dviem vyksmais per periodą (Lind, A. 2013):

1. Atsidarius raktui Q1 (1.10 pav. a), pirminèje keitiklio grandinèje kontūru teka srovė $I_{1}$, ši srovè kuria transformatoriaus antrinèje grandinejje srovę $I_{2}$. Srove $I_{2}$ per diodą D2 induktyviajame ir talpiniame elementuose L1 ir C1 kaupia energiją reikalingą išèjimo srove maitinti apkrovą, kai raktas Q1 būna uždarytas.

2. Užsidarius raktui Q1 (1.10 pav. b), pirminèje keitiklio grandinèje generuojama parazitinè srovė $I_{\mathrm{sp}}$, kurią sąlygoja impulsinio transformatoriaus parazitiniai induktyvumai susiję su magnetinio srauto sklaida transformatoriaus magnetolaidyje. Šiai srovei gesinti įdiegta papildoma, atvirkščiai ijungta, trečia transformatoriaus apvija. Ji per diodą D1 gražina $I_{\mathrm{sp}}$ srovę atgal ị pirminị maitinimo šaltinį. Antrinès grandinès srovė $I_{2}$ tiekiama ị keitiklio apkrovą.

Vientaktis tiesioginis keitiklis naudojamas mažos galios mikroinverteriuose, kurių galia yra nuo 50 iki $350 \mathrm{~W}$. Veikiant didesne galia, tokiems keitikliams 
transformatoriaus magnetolaidyje pasireiškia ženkli magnetinio srauto sklaida, kuri keitiklio galios grandyse saviindukuoja parazitines sroves $I_{\mathrm{sp}}$ ir kuria galios nuostolius (Bulut et al. 2018; Kim et al. 2017), todèl energetinio efektyvumo požiūriu jų taikymas tampa neracionalus. Didesnei galiai, siekiančiai iki $3 \mathrm{~kW}$, naudojami dviejų raktų tiesioginiai nuolatinès įtampos keitikliai. Juose parazitinès srovès, atsirandančios dèl transformatoriuje esančių magnetinio srauto sklaidos reiškinių, gesinimui naudojama pirminè apvija (Zhao et al. 2007; Bodur et al. 2018).

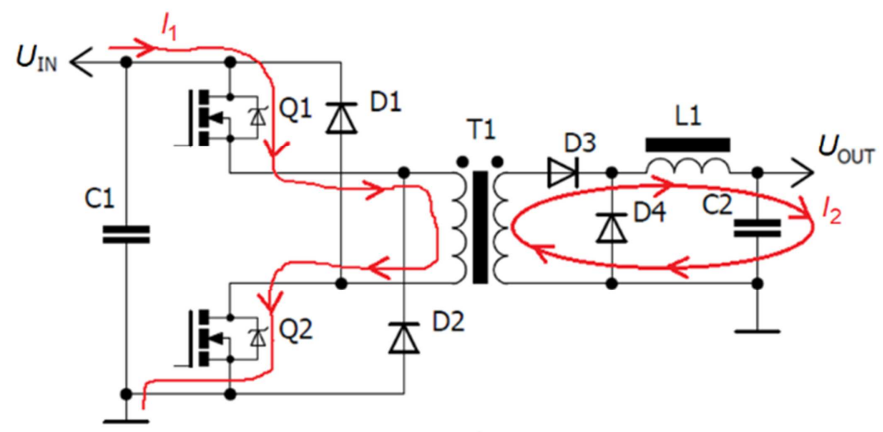

a)

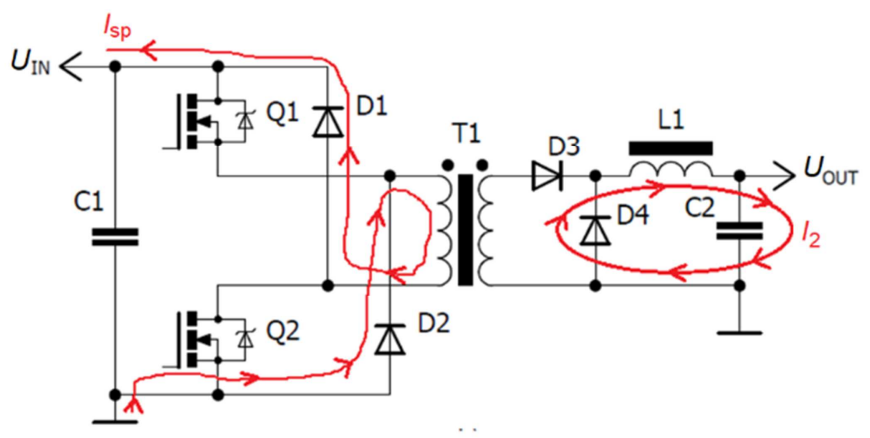

b)

1.11 pav. Dviejų raktų tiesioginio keitiklio principinè elektrinė schema ir veikimo principas: a) energijos perdavimas antrinei grandinei, kai Q1 ir Q2 raktų tranzistoriai atidaryti; b) energijos perdavimas antrinei grandinei, kai Q1 Q2 raktų tranzistoriai uždaryti

Fig. 1.11. Circuit diagram and operation of two swich forward converter: (a) power transfer to the secondary circuit when the Q1 and Q2 key transistors are in state ON;

b) power transfer to the secondary circuit when the Q1 and Q2 key transistors are in state 
Dviejų raktų tiesioginio nuolatinès ịtampos keitiklio elektrinė schema pateikta 1.11 paveiksle. Veikimo principas panašus kaip ir vieno rakto tiesioginio nuolatinès įtampos keitiklio:

1. Pirmojo ciklo metu (1.11 pav. a), atsidarius raktams Q1 ir Q2, transformatoriaus T1 pirmine apvija pradeda tekèti srove $I_{1}$, kuri sąlygoja srovę $I_{2}$ antrinèje keitiklio grandinèje. Srovès $I_{2}$ tiekiama energija yra kaupiama reaktyviniuose elementuose L1 ir C2 antrajam periodo ciklui ir yra tiekiama ị keitiklio apkrovą.

2. Antruoju ciklo periodu (1.11 pav. b), raktų Q1 ir Q2 raktų tranzistoriai uždaromi - nutrūksta pirminio kontūro srové $I_{1}$. Antrinëje keitiklio grandinëje srovè per diodą D4 palaikoma naudojant reaktyviuosiuose elementuose L1 ir C2 sukauptą energiją. Tiesioginio keitiklio transformatoriaus T1 magnetolaidyje susidarius magnetinio lauko srauto sklaidai, pirminejje keitiklio grandinejje indukuojasi nuotékio parazitinè srovė $I_{\mathrm{sp}}$, kuri diodais D1 ir D2 nukreipiama atgal ị pirminị elektros energijos šaltinị.

Dviejų raktų tiesioginiai keitikliai paplitę fotovoltinių jègainių, kurių galia viršija $1 \mathrm{~kW}$, inverteriuose.

Dviejų raktų tiesioginio keitiklio trūkumai yra šie:

1. Q1 tranzistoriaus valdymo schemai (1.11 pav.) būtinas individualus izoliuotas nuo bendrosios žemės maitinimo šaltinis;

2. Keitiklio igyvendinimui reikalingas santykinai didelis komponentų skaičius, kas mažina tokio keitiklio efektyvumą ir patikimumą.

\subsubsection{Grįžtamieji nuolatinès įtampos keitikliai}

Grį̌tamieji nuolatinès įtampos keitikliai yra dažnai taikomi fotovoltiniuose mikroinverteriuose, nes šie keitikliai gerai veikia srovès šaltinio režimu, todėl gerai tinka tinklo mikroinverterių kūrimui. Kiti keitikliai, pvz.: tiesioginiai keitikliai, šiuo atveju yra mažiau tinkami, nes veikia kaip įtampos šaltiniai.

Grị̌tamieji nuolatinès įtampos keitikliai turi specifinį ferito šerdies impulsinį transformatorių su oro tarpu, kuris vadinamas grịžtamuoju transformatoriumi (Keogh et al. 2016). Grị̌tamojo nuolatinès ịtampos keitiklio elektrinè schema ir veikimo principas atvaizduoti 1.12 ir 1.13 paveiksluose. Kiekvieno impulsinès įtampos, formuojamos transformatoriaus pirminejje apvijoje, periodo T metu galima išskirti du vyksmus (1.13. pav.):

1. Pirmojo vyksmo (1.12 pav. a) metu rakto Q1 tranzistorius atviras (ciklo dalis $D, 1.13$ paveikslas), pirmine transformatoriaus apvija 
sujungiama su maitinimo šaltiniu, teka srovė $I_{1}$. Transformatoriaus magnetiniame lauke kaupiama energija.

2. Antrojo vyksmo (1.12 pav. b) metu rakto Q1 tranzistorius uždaras (ciklo dalis D' 1.13 paveikslas), magnetiniame lauke sukaupta energija indukuojama $\mathfrak{i}$ antrinę apviją. Indukuota antrinès apvijos įtampa $U_{\text {OUT }}$ užkraunamas kondensatorius $\mathrm{C} 1$, maitinama apkrova. Dalis magnetinio lauko energijos grị̌zta i pirminę apviją kaip magnetinio srauto sklaidos kuriamos saviindukcijos elektrovara $U_{\text {sp. }}$. Ši elektrovara kuria viršitampius, kurie sukuria papildomus srovès kontūrus. Šie srovès kontūrai kuria energijos nuostolius, kaitindami keitiklio elementus.

Kadangi viršįampiai gali sugadinti rakto tranzistorių Q1, būtina naudoti viršitampius gesinančią grandinę, kuri kaupia viršįtampio energiją ir nukreipia atgal i pirmini energijos šaltinị $U_{\mathrm{IN}}$. Taikoma nemažai ịvairių metodų viršitampiams gesinti panaudojant papildomas elektronines grandines. Naudojamos ir papildomos grandinès su aktyviais raktais, kurie viršitampio sukurtas sroves nukreipia i reaktyvinius elementus. Reaktyviniuose elementuose sukaupta viršitampio energija nukreipiama atgal i pirminị maitinimo šaltini ir tokiu būdu yra panaudojama sekantiems keitiklio darbo ciklams, kas leidžia padidinti keitiklio naudingumo koeficientą.

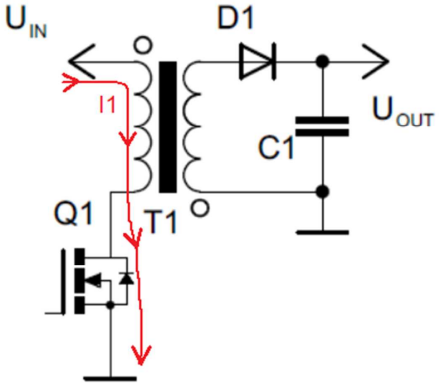

a)

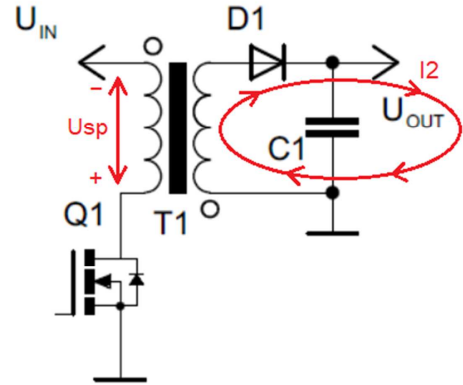

b)

1.12 pav. Grịžtamojo nuolatinès ịtampos keitiklio elektrinè schema ir veikimo principas: a) energijos kaupimas grįžtamojo transformatoriaus magnetinejje sistemoje; b) energijos perdavimas antrinei apvijai

Fig. 1.12. Circuit diagram of flyback DC-DC converter and operating principle: a) energy storage in the magnetic system of the flyback transformer; (b) energy transmission to the secondary winding of transformer

Per pastaruosius keletą metų paskelbta daug darbų, skirtų grịžtamųjų nuolatinès įtampos keitiklių tyrimams (Halder. 2018; Fermin et al. 2015; Š́ly, V et al. 2015; Lopez et al. 2017; Schmitz et al. 2017; Min et al. 2018; Öztürk et al. 
2015; Ryu et al. 2018; Dong et al. 2015; Morales-Caporal et al. 2016; Haji et al. 2018; Umuhoza et al. 2017; Golembiovskiy et al. 2018; Pan et al. 2016; Jin et al. 2012; Anku et al. 2013; Tan et al. 2012; Ko et al. 2016; Sankar et al. 2017; Jaballah et al. 2015; Schuepbach et al. 2015; Jäger-Waldau et al. 2018; Raziei et al. 2014; Kharitonov et al. 2012; Firdaus et al. 2018; Seliga et al. 2014; Azli et al. 2008; Chowdhury et al. 2014). Viena tokio susidomejjimo šiais keitikliais priežasčių yra mikroinverterių, skirtų saulès elektrinių integracijai ị elektros tinklą, plètra, nes grịžtamieji nuolatinès įtampos keitikliai pasižymi, paprastumu, energetiniu efektyvumu ir žema savikaina.

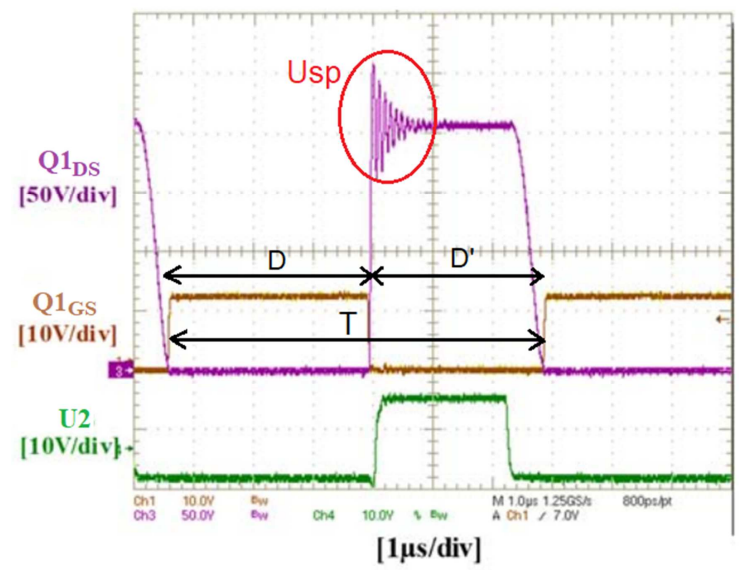

1.13 pav. Tranzistoriaus Q1 įtampų pereinamieji procesai: D - Q1 atviras; D' - Q1 uždaras. Purpurine - ištakos-santakos ịtampa; ruda užtūros-santakos įtampa; žalia transformatoriaus išèjimo srovè $U_{2} / R_{\text {shunt }}$

Fig. 1.13. Transients of transistor voltages: $D-Q 1$ is in state $O N ; D^{\prime}-Q 1$ is in state OFF. Purple - source-drain voltage; brown - gate-drain voltage; green - transformer output current $U_{2} / R_{\text {shunt }}$

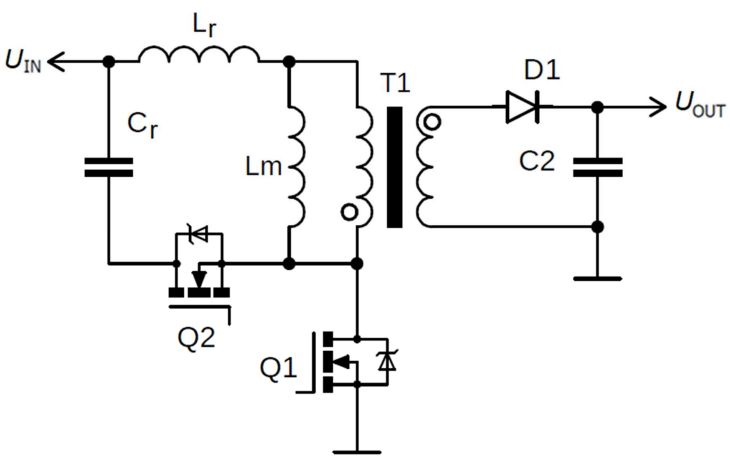

1.14 pav. Rezonansinio grịžtamojo nuolatinès ịtampos keitiklio elektrinè schema

Fig. 1.14. Circuit diagram of the resonant DC/DC flyback converter 
Sukurta grịžtamojo nuolatinès ịtampos keitiklio modifikacija, kurios naudingumo koeficientas siekia 0,96 (Chowdhury et al. 2014). Viena iš tokių modifikacijų (Perrin et al. 2016, Xue et al. 2018) pateikta 1.14 paveiksle. Joje siūlomas rezonansinis grịžtamasis keitiklis, naudojant aktyviuosius viršitampio gesinimo raktus.

Lyginant su klasikiniu grịžtamuoju keitikliu, rezonansinio keitiklio elektrinė schema yra papildyta $\mathrm{Cr}$ rezonansine talpa ir raktu Q2. Lr yra grị̌tamojo transformatoriaus magnetinio sklaidos srauto dedamoji (angl. leakage inductance); Lm - grịžtamojo transformatoriaus šerdị įmagnetinančios indukcijos dedamoji (angl. magnetizing inductance). Kai rakto Q1 tranzistorius yra atsidaręs - keitiklis veikia kaip klasikinis grižtamasis keitiklis - kaupiama energija transformatoriaus magnetolaidyje. Kai rakto Q1 tranzistorius uždarytas, sukaupta energija perduodama $\mathfrak{i}$ antrinejje grandinejje esančio grịžtamojo transformatoriaus apviją. Kai pirminejje keitiklio grandinejje atsidaro rakto Q2 tranzistorius, tuomet veikiant nuosekliai sujungtiems $\mathrm{Lr}$ ir $\mathrm{Cr}$ elementams, gesinamas viršitampis (Perrin et al. 2016). Dalis sukauptos talpoje Cr energijos perduodama atgal i grịžtamajị transformatorių, t. y. rezonanso metu viršįtampio energija atgręžiama atgal transformatoriumi ị apkrovą (Perrin et al. 2016).

Taip pat yra siūloma naudoti hibridinę RCD grandinę viršįtampiams grị̌tamajame nuolatinès įtampos keitiklyje gesinti (Huber et al. 2018) (1.15 pav.). Energijos kaupimo procese atidaromas rakto Q1 tranzistorius. Uždarius rakto Q1 tranzistorių, atsidaręs Q2 rakto tranzistorius patrumpina Šotki diodą $\mathrm{D}_{\mathrm{cl}}$ padidindamas aktyviosios gesinimo grandinès laidumą. Magnetinio sklaidos srauto kuriamo viršitampio energija akumuliuojama gesinimo grandinès kondensatoriuje $\mathrm{C}_{\mathrm{cl}}$. Rezistorius $\mathrm{R}_{\mathrm{cl}}$ dali energijos paverčia $\mathfrak{i}$ šiluminę energiją taip apsaugodamas keitiklio elementus nuo pavojingos sukauptos kondensatoriuje $\mathrm{C}_{\mathrm{cl}}$ energijos.

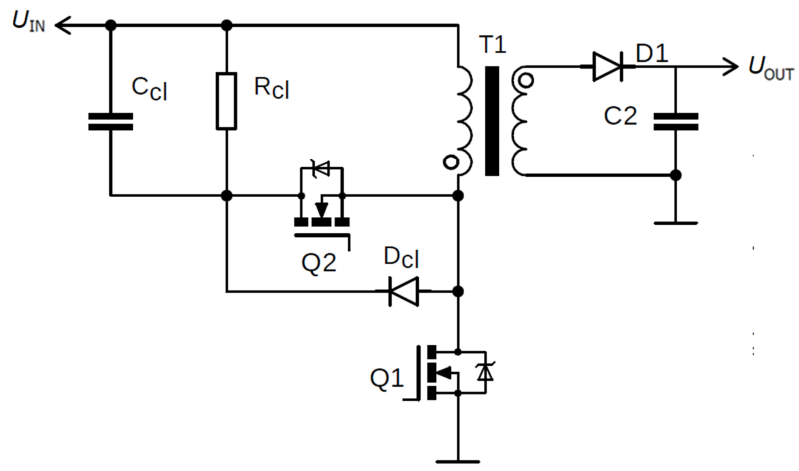

1.15 pav. Grịžtamasis keitiklis su hibridine gesinimo grandine

Fig. 1.15. Flyback converter with hybrid clamp 
Taip pat naudojamas hibridinis dviejų raktų grįžtamasis nuolatinės įtampos keitiklis, kurio elektrinè schema pateikta 1.16. paveiksle. Atsidarius raktų tranzistoriams Q1 ir Q2, transformatoriaus magnetiniame lauke kaupiama energija. Užsidarius tranzistoriams Q1 ir Q2, didžioji dalis energijos indukuojama ị antrinę grandinę. Dalis grịžusios energijos dèl magnetinio lauko srauto nuotèkio ị pirminę apviją, nukreipiama ị maitinimo šaltinį $U_{\mathrm{IN}}$ per $\mathrm{D}_{\mathrm{c} 1}$ ir $D_{\mathrm{c} 2}$ diodus, kita dalis likutinès energijos regeneruojama $D_{\mathrm{s} 1}, \mathrm{D}_{\mathrm{s} 2}, \mathrm{C}_{\mathrm{s} 1}, \mathrm{C}_{\mathrm{s}} 2 \mathrm{D}_{\mathrm{s}}$ ir $\mathrm{L}_{\mathrm{s}}$ komponentų sudarytais srovių kontūrais.

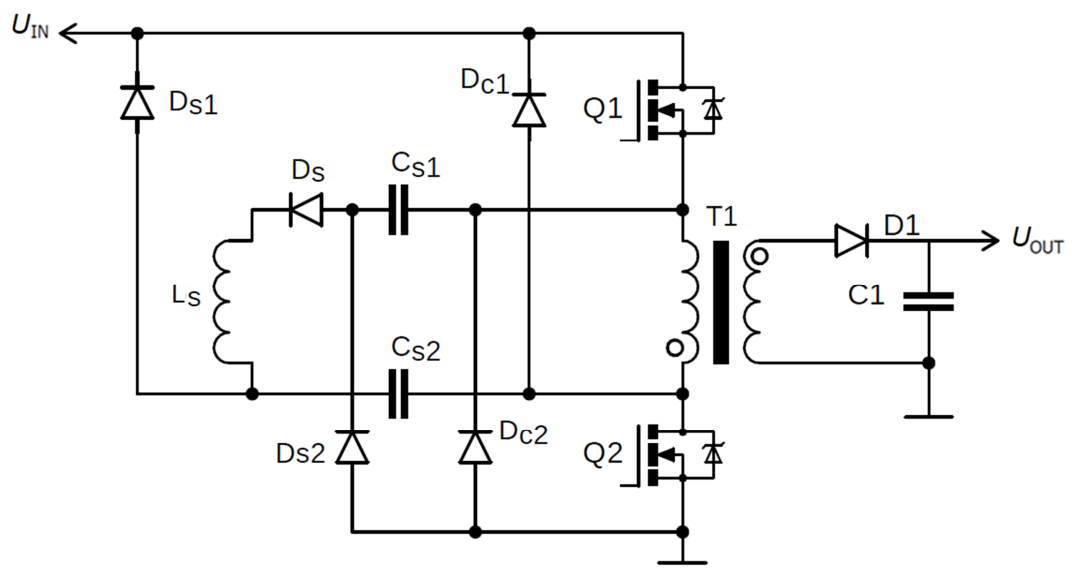

1.16. pav. Grịžtamojo keitiklio elektrinè schema su aktyviomis viršitampio gesinimo grandinèmis

Fig. 1.16. Circuit diagram of flyback converter with active clamp circuit

Apibendrinant atliktą analizę, galima ịvardyti, kad pagrindiniai grịžtamujjų nuolatinès ịtampos keitiklių privalumai yra tai, kad jis gerai veikia srovès šaltinio režimu, todèl gerai tinka tinklo mikroinverterių realizavimui, taip pat šio tipo keitikliai pasižymi aukštu energetiniu efektyvumu, paprastumu ir maža savikaina.

Iš kitos pusès, grịžtamieji nuolatinės ịtampos keitikliai turi šiuos trūkumus: dèl oro tarpo grịžtamojo transformatoriaus magnetinèje sistemoje pasireiškia magnetinio srauto sklaidos reiškiniai, generuojantys viršịtampius komutuojant apvijas; pirminejje keitiklio galios grandinejje reikia naudoti dvigubai didesnès maksimalios įtampos tranzistorius dèl antrinès apvijos atspindžio įtampos (angl. mirror voltage) ir susidarančių viršitampių. 


\subsection{Pirmojo skyriaus išvados ir disertacijos uždavinių formulavimas}

Atlikus analizę disertacijos tema, suformuluotos šios išvados:

1. Pagrindinis mikroinverterių pranašumas, lyginant su didelès galios inverteriais, yra tas, kad naudojant mikroinverterius maksimalios galios režimas yra garantuojamas individualiai kiekvienam fotovoltiniam moduliui.

2. Didžiausi galios nuostoliai mikroinverteriuose formuojasi nuolatinès itampos keitiklyje, kurio naudojimas mikroinverteriuose yra neišvengiamas, nes fotovoltinio modulio tiekiamą ịtampą būtina paaukštinti iki tinklo įtampos amplitudès vertès.

3. Grịžtamieji nuolatinès ịtampos keitikliai gali dirbti srovès šaltinio režimu. Šio tipo keitikliai pasižymi aukštu naudingumo koeficientu, paprastumu ir maža savikaina, todèl gerai tinka tinklo mikroinverterių kūrimui.

4. Norint padidinti mikroinverterio naudingumo koeficientą, būtina rasti sprendimus, leidžiančius kurti mikroinverterị naudojant minimalų raktų kiekį, ir raktų tranzistorius su sumažinta atviro tranzistorius varža.

5. Raktų persijungimo metu, dèl impulsinio transformatoriaus specifikos, saviindukuojasi viršitampiai, kurie sukuria sroves viršitampio slopinimo grandinèse, sukeldami papildomus galios nuostolius, todèl aktualu tobulinti mikroinverterių impulsinị transformatorių, siekiant mažinti viršįtampius.

6. Srovè, kurią mikroinverteris tiekia i elektros tinklą, harmonikų mažinimui būtina ị mikroinverterio struktūrą ịterpti automatinio valdymo sistemą su grịžtamuoju ryšiu, skirtą sinuso dèsnio sekimui. Šiam tikslui dažniausiai naudojami PI ir PID valdikliai, tačiau šie valdikliai negarantuoja tikslaus srovès valdymo.

Atlikus analizę disertacijos tema, suformuluoti šie uždaviniai:

1. Sukurti energetiškai efektyvų nuolatinès įtampos keitiklị ir jo pagrindu sukurti vienos pakopos fotovoltini mikroinverterị bei ji eksperimentiškai ištirti. 
2. Sukurti valdymo algoritmą ir ji ịgyvendinantị valdiklị tiekiamos $\mathfrak{i}$ elektros tinklą mikroinverterio srovès valdymui, valdymo sistemą ištirti modeliuojant bei eksperimentiškai.

3. Ištirti sukurto fotovoltinio mikroinverterio elementų parametrų įtaką mikroinverio naudingumo koeficientui, modeliuojant, patobulinti ir eksperimentiškai ištirti grįžtamajji transformatorių. 



\section{Energetiškai efektyvaus fotovoltinio mikroinverterio galios dalies kūrimas ir tyrimas}

Šiame skyriuje pateikti grị̌tamụjų nuolatinès įtampos aukštinančiųjų keitiklių ir, jais besiremiančio energetiškai efektyvaus fotovoltinio mikroinverterio, kūrimo ir eksperimentinio tyrimo rezultatai. Gauti rezultatai paskelbti trijose publikacijose (Bielskis et al. 2018; Bielskis et al 2017; Bielskis et al 2016b). Tyrimai buvo atlikti Fizinių ir technologijos mokslo centro Elektroninių sistemų laboratorijoje ir Šiaulių universiteto Galios elektronikos laboratorijoje. Atliktais tyrimais buvo siekiama sukurti aukšto energetinio efektyvumo fotovoltinị mikroinverterị, kuriame tiek nuolatinès įtampos paaukštinimas tiek jos keitimas ị kintamają atliekamas toje pačioje pakopoje, kas leidžia supaprastinti inverterio konstrukciją. 


\subsection{Klasikinis nuolatinès ịtampos grị̌tamasis keitiklis su aktyviąa viršitampio gesinimo grandine}

Tiriamasis klasikinis aukštinantysis nuolatinès ịtampos grịžtamasis keitiklis yra plačiai naudojamas fotovoltiniuose mikroinverteriuose (Surapaneni et al. 2015; Zhang et al. 2013; Lai et al. 2014). Tyrimų tikslas - eksperimentiškai ištirti šio keitiklio naudingumo koeficientą. Gauti rezultatai bus naudojami pasiūlytų nuolatinès įtampos keitiklių palyginamajam ịvertinimui.

\subsubsection{Klasikinio grịžtamojo keitiklio su aktyviąja viršịtampio gesinimo grandine elektrinè schema ir veikimo principas}

Šio grị̌tamojo nuolatinès ịtampos aukštinančiojo keitiklio ypatybė yra ta, kad jis turi aktyviają viršitampio gesinimo grandinę, gebančią transformatoriaus saviindukcijos energiją grąžinti atgal i maitinimo šaltini (Halder. 2018; Fermin et al. 2015; Š́ly et al. 2015; Lopez et al. 2017; Schmitz et al. 2017; Min et al. 2018). Tokio keitiklio elektrinè schema pateikta 2.1 paveiksle.

Išskiriami du klasikinio nuolatinès įtampos grịžtamojo keitiklio su aktyviąja viršitampio gesinimo grandine veikimo ciklai per periodą:

1. Atsidarius lauko tranzistoriui Q1 (2.1 pav. a), pirmine T1 transformatoriaus apvija teka srovè $I_{\mathrm{pri}}$. Transformatoriaus magnetiniame lauke kaupiama energija. Kondensatoriaus C1 sukauptu krūviu maitinama apkrova.

2. Užsidarius tranzistoriui Q1 (2.1 pav. b), atsidaro tranzistorius Q2. Magnetiniame lauke sukaupta energija indukuoja i antrinę apviją srovę $I_{\text {sec }}$, ikkraunamas kondensatorius $\mathrm{C} 1$, maitinama apkrovą. Dėl magnetinio lauko srauto sklaidos transformatoriaus T1 magnetolaidyje, dalis magnetinio lauko energijos grižta kaip viršitampis $U_{\mathrm{sp}}$ (angl. voltage spike) atgal i pirminę apviją ir pasiduoda i lauko tranzistoriaus santakos-ištakos grandinę. Viršįtampio $U_{\mathrm{sp}}$ generuojama srove $I_{\mathrm{sp}}$ nukreipiama i pirminị maitinimo šaltinį panaudojant aktyviąą grandinę, kurią sudaro tranzistorius Q2 ir kondensatorius C2. Q2 ir C2 elementais saviindukuotas viršįtampis užgesinamas iki nepavojingos Q1 tranzistoriaus tiesioginès ịtampos.

Mikroinverteryje naudojami du tokie aukštinantieji nuolatinès įtampos keitikliai, kurie ittampos aukštinimą atlieka sinchroniškai, perstumiant IPM ìtampos fazę $180^{\circ}$. Grịžtamuosiuose keitikliuose naudojami impulsiniai transformatoriai su ferito šerdimis, kurie savo magnetinèje sistemoje turi oro 
tarpą. Oro tarpas reikalingas, kad šerdis neįsisotintų ir gebètu sukaupti daugiau energijos (Causo et al. 2013, Xiangjun et al. 2003).

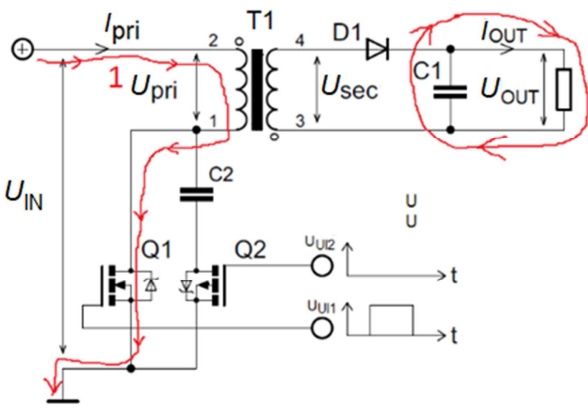

a)

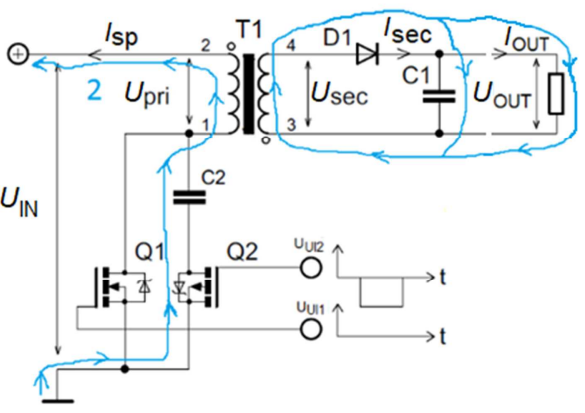

b)

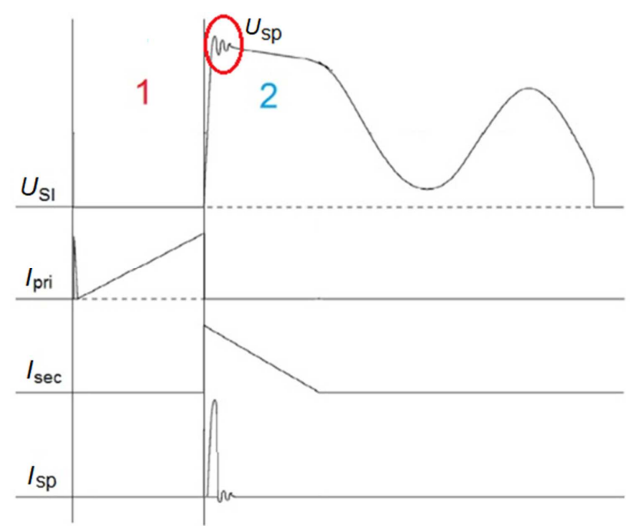

c)

2.1 pav. Grịžtamojo keitiklio elektrinè schema: a) pirmo veikimo ciklo srovès kontūrai; b) antro veikimo ciklo srovių kontūrai; c) srovès pereinamieji procesai pirmajame ir antrajame veikimo cikluose

Fig. 2.1. Circuit diagram of flyback converter: a) current loops of first operation cycle; b) current loops of second operation cycle; c) current transients during the first and second operating cycles

\subsubsection{Klasikinio grįžtamojo keitiklio su aktyviąja viršịtampio gesinimo grandine naudingumo koeficiento tyrimas}

Tiriamo klasikinio nuolatinès įtampos aukštinančiojo grižtamojo keitiklio su aktyvine viršitampio gesinimo grandine elektrinè schema pateikta 2.2 paveiksle. Jị sudaro du vienodi grị̌tamieji nuolatinès ịtampos keitikliai. Kiekvieną keitiklị sudaro raktų tranzistorius valdanti mikroschema IC1 (MCP14E4-E/SN), n tipo kanalo lauko tranzistorius Q1 (IRFS4321TRLPBF) transformatoriaus pirminès 
apvijos komutavimui, p tipo kanalo lauko tranzistorius Q2 (SI7115DN-T1-GE3) aktyviajam viršįtampio gesinimui, grịžtamasis transformatorius. IPM signalas i tranzistorių valdymo schemas tiekiamas iš impulsinio signalo generatoriaus (SG3525), skirto raktų tranzistorių valdymui. Jis tiekia du priešingos fazès IPM signalus, kurių skvarbą $D$ galima valdyti nuo 0 iki $48 \%$.

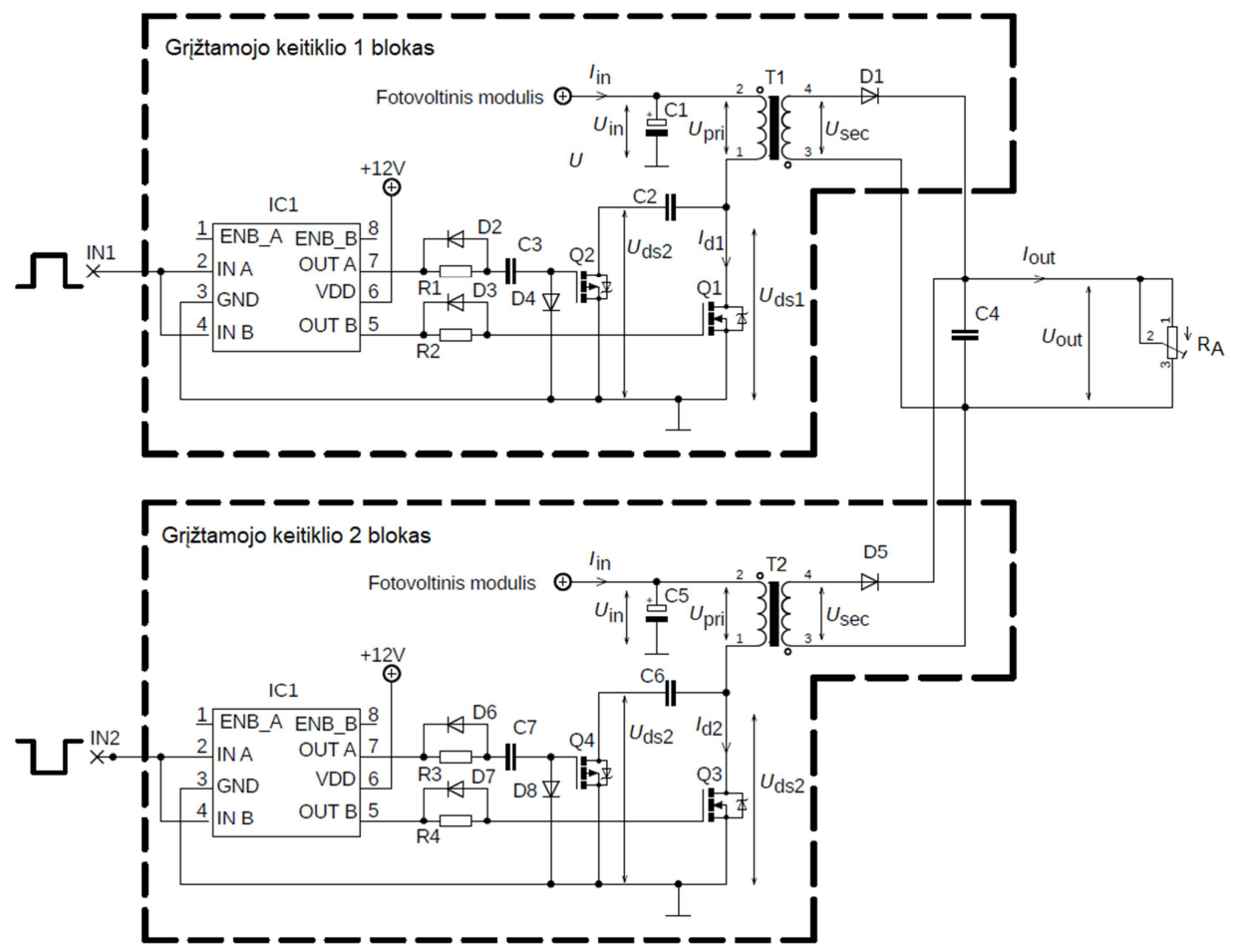

2.2 pav. Klasikinio nuolatinès įtampos aukštinančiojo grịžtamojo keitiklio elektrinè schema

Fig. 2.2. The circuit diagram of the classical DC/DC Flyback converter

Grižtamasis keitiklis buvo maitinamas $30 \mathrm{~V}$ ịtampa. Jis buvo apkrautas reostatu, kurio varža $R_{\mathrm{A}}=430 \Omega$. Grịžtamojo keitiklio tyrimai atlikti prie fiksuotos apkrovos varžos, prie šių IPM signalo, kuriais valdomi keitiklio raktai, dažnių: 25; 36; 60 ir $90 \mathrm{kHz}$. Tiekiama ị apkrovą galia buvo valdoma keičiant IPM signalo impulsų skvarbą. Naudingumo koeficientui nustatyti buvo matuojama tiekiama ị keitiklị galia ir galia tiekiama iš keitiklio ị apkrovą $R_{\mathrm{A}}$. Gautos naudingumo koeficiento priklausomybès nuo grižtamojo keitiklio tiekiamos ị apkrovą galios ir raktų komutavimo dažnio pateiktos 2.3 paveiksle. 
Matavimams buvo naudojamas Fluke 8846A multimetras, kurio maksimali matavimo paklaida $0,1 \%$.

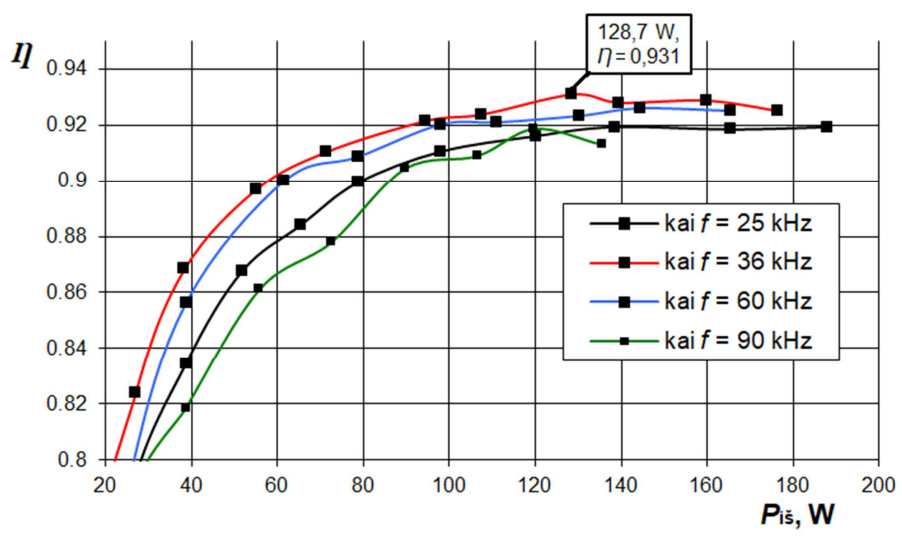

2.3 pav. Naudingumo koeficiento priklausomybė nuo grị̌žamojo keitiklio tiekiamos ị apkrovą galios skirtingiems raktų komutavimo dažniams, esant fiksuotai apkrovos varžos vertei $R_{\mathrm{A}}=430 \Omega$

Fig. 2.3. Flyback converter efficiency dependence on converter output power at various PWM frequencies and fixed load resistance $R_{\mathrm{A}}=430 \Omega$

Iš gautų rezultatų matyti, kad keitiklio naudingumo koeficientas didèja augant tiekiamai ì apkrovą galiai. Tačiau maždaug prie $120 \mathrm{~W}$ galios naudingumo koeficientas nustoja augęs. Naudingumo koeficientas taip pat priklauso ir nuo keitiklio raktų komutavimo dažnio. Didžiausia naudingumo koeficiento vertė 0,93 pasiekta prie $36 \mathrm{kHz}$ raktų komutavimo dažnio, keitikliui tiekiant $128,7 \mathrm{~W}$ galią. Esant $25 \mathrm{kHz}$ dažniui gautas naudingumo koeficientas yra mažesnis dèl didesnès grį̌tamojo keitiklio pirminės apvijos srovès, kuri sukuria didesnius vario nuostolius transformatoriaus grandinëje ir didesnị įtampos kritimą atviro rakto tranzistoriaus grandinèje. Esant $90 \mathrm{kHz}$ raktų komutavimo dažniui, galios nuostolius didina išaugę komutaciniai nuostoliai raktuose Q1 ir Q2 (Causo et al. 2013), nes raktai dažniau junginejjasi, o persijungimo metu galios nuostoliai raktuose yra nepalyginamai didesni nei statinejje būsenoje, kai rakto tranzistorius yra atviras arba uždaras. Komutaciniai nuostoliai gali būti apskaičiuojami pagal formulę:

$$
P_{\text {nuost. }}=\frac{1}{2} I_{\text {maks. }} \cdot V_{\mathrm{IS}} \cdot t_{\text {išj. }},
$$

čia $I_{\text {maks. }}$ - atviro tranzistoriaus srovè; $V_{\text {Is }}$ - įtampos kritimas ant ištakos-santakos atvirame lauko tranzistoriuje; $t_{\text {iš. }}$ - pereinamojo vyksmo trukmé uždarant tranzistoriaus laidujji kanalą. 
Kitu bandymu buvo tiriama grịžtamojo keitiklio naudingumo koeficiento priklausomybè nuo apkrovos galios, keičiant apkrovos varžą $R_{\mathrm{A}}$, prie dviejų fiksuotų IPM signalo skvarbos verčių: $D=35 \%$, ir $D=44 \%$. Tyrimai atlikti šiems raktų komutavimo dažniams: 25; 36; 60 ir $90 \mathrm{kHz}$. Gauti rezultatai pateikti 2.4 ir 2.5 paveiksluose.

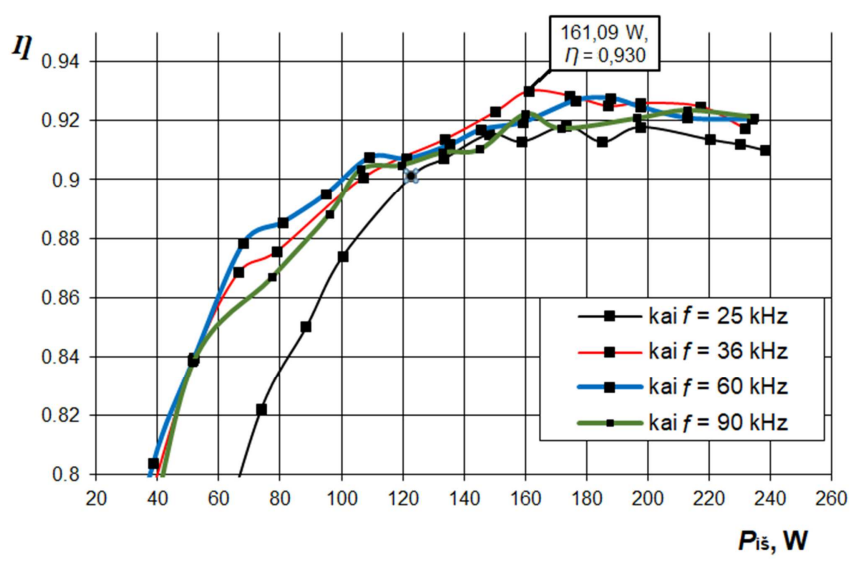

2.4 pav. Naudingumo koeficiento priklausomybè nuo grižtamojo keitiklio tiekiamos ị apkrovą galios, skirtingiems raktų komutavimo dažniams, esant fiksuotai impulso pločio skvarbai $D=35 \%$

Fig. 2.4. Flyback converter efficiency dependence on converter output power at various PWM switching frequencies and fixed duty cycle $D=35 \%$

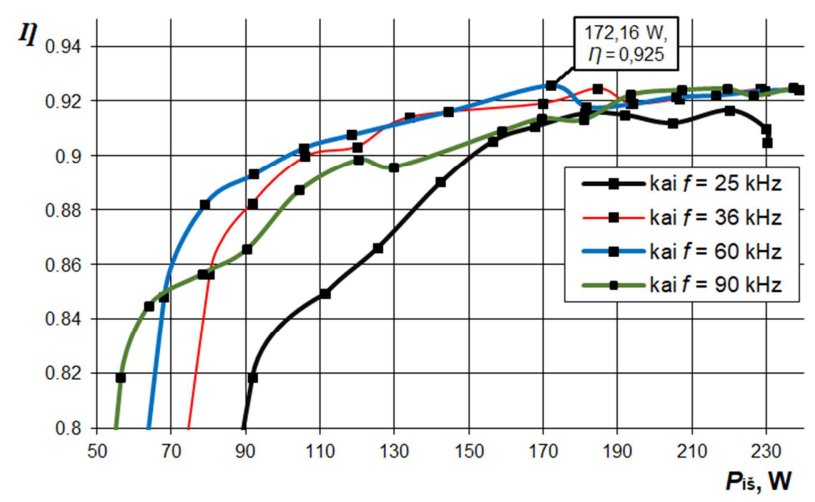

2.5 pav. Naudingumo koeficiento priklausomybè nuo grižtamojo keitiklio tiekiamos $\mathfrak{i}$ apkrovą galios, skirtingiems raktų komutavimo dažniams, esant fiksuotai impulso pločio skvarbai $D=44 \%$

Fig. 2.5. Flyback converter efficiency dependence on converter output power at various PWM frequencies and fixed duty cycle $D=44 \%$ 
Iš gautų (2.4 ir 2.5 pav.) eksperimento rezultatų matyti, kad aukščiausias keitiklio naudingumo koeficientas yra prie 36 ir $60 \mathrm{kHz}$ raktų komutavimo dažnio. Prie 25 ir $90 \mathrm{kHz}$ raktų komutavimo dažnio keitiklio naudingumas gaunasi mažesnis dèl tų pačių priežasčių, kurios buvo ịvardytos aukščiau, t. y. atitinkamai, dèl didesnių galios nuostolių transformatoriaus ir atviro rakto tranzistoriaus grandinèse ir dèl didesnių komutacinių nuostolių rakto tranzistoriuje. Maksimalus $93 \%$ keitiklio naudingumo koeficientas gavosi prie $36 \mathrm{kHz}$ raktų komutavimo dažnio, esant $161 \mathrm{~W}$ apkrovos galiai ir $35 \%$ impulsų skvarbai.

Bandymų metu pastebėta, kad esant mažesnei kaip $70 \mathrm{~W}$ apkrovimo galiai padidèja tranzistorių Q2 ir Q4 (2.2 pav.) galios nuostoliai, lyginant su nuostoliais esant didesnei apkrovos galiai. Tranzistorių Q2 ir Q4 galios nuostoliai išauga, nes antrinè apvija dèl nedidelès aprovimo galios nesugeba pasisavinti sukauptos energijos transformatoriaus magnetolaidyje. Todèl didesnè likutinès energijos dalis magnetolaidyje grịžta atgal ị pirminę apviją. Grįžtanti srové per Q2 ir Q4 tranzistorius ženkliai padidèja dèl neperduotos energijos antrinei transformatoriaus apvijai.

\subsection{Nuolatinès ịtampos grị̌tamasis keitiklis su alternatyvia aktyvine viršitampio gesinimo grandine}

Sukurtas ir ištirtas alternatyvus klasikiniam keitiklis. Pasiūlytas keitiklis skiriasi nuo klasikinio aktyviosios viršitampio gesinimo grandinès sprendimu.

\subsubsection{Keitiklio su alternatyvia aktyviąja viršịtampio gesinimo grandine elektrinè schema ir veikimo principas}

Keitiklio su alternatyvia aktyviajja viršitampio gesinimo grandine elektrinè schema pateikta 2.6 paveiksle. Sis keitiklis, kaip ir klasikinis (2.2 pav.), sudarytas iš dviejų identiškų blokų (1-as blokas Q1, Q2 ir 2-as blokas Q3, Q4 ir T2), dirbančių priešfazèje, t. y. kai 1 bloko raktas Q2 yra atviras, antro bloko raktas Q4 yra uždaras ir atvirkščiai, jei Q2 uždaras, tai Q4 atviras. IPM signalas i raktų valdymo schemas tiekiamas iš impulsinio signalo generatoriaus SG3525, kaip ir tiriant klasikinị grịžtamajji nuolatinès ịtampos keitiklị.

Siūlomo keitiklio skirtumai nuo klasikinio keitiklio:

1. Klasikinio keitiklio (2.2 pav.) aktyviojoje viršįtampio gesinimo grandineje naudojami Q2 ir Q4 lauko tranzistoriai su p kanalu. Siūlomo patobulinto keitiklio (2.6 pav.) viršịtampio gesinimo grandiné sukurta naudojant Q1 ir Q3 tranzistorius su n tipo kanalu. 
Privalumas - lauko tranzistoriai su n tipo kanalu turi spartesnę greitaveiką ir mažesnę atviro tranzistoriaus varžą.

2. Viršitampių gesinimo grandinès tranzistorių valdymui naudojamas signalas paduodamas atžvilgiu ,žemès“, todèl valdymo grandinè yra paprasta. Tranzistoriai su p tipo kanalu valdomi ne atžvilgiu „žemès“, naudojant neigiamo poliaringumo impulsus. Todèl tranzistoriaus valdiklis yra sudètingesnis nei tranzistoriaus su $\mathrm{n}$ kanalu.

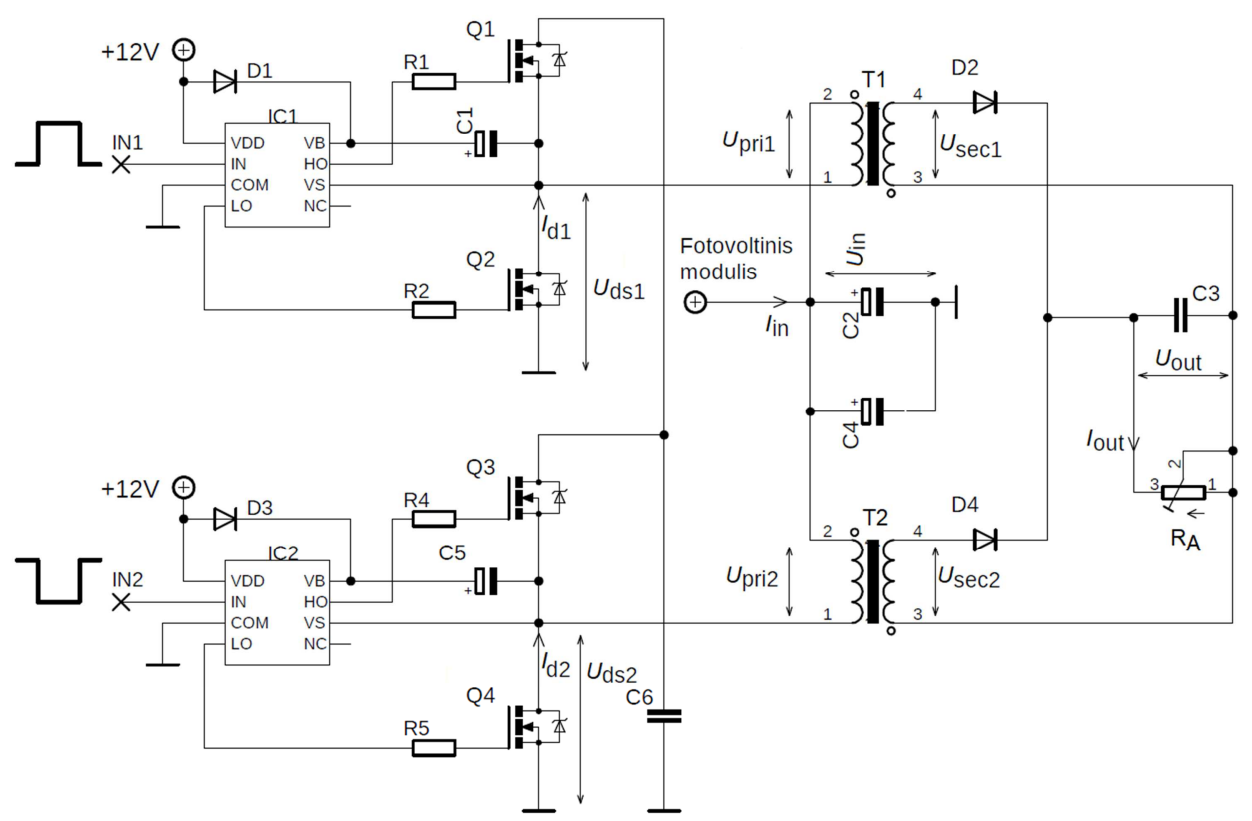

2.6 pav. Keitiklio su alternatyvia aktyviaja viršįtampio gesinimo grandine elektrinè schema

Fig. 2.6. The circuit diagram of the DC/DC flyback converter with the alternative active overvoltage suppresion

\subsubsection{Keitiklio su alternatyvia aktyviajja viršĭtampio gesinimo grandine naudingumo koeficiento tyrimas}

Keitiklis su alternatyvia aktyviaja viršitampio gesinimo grandine buvo tiriamas analogiškai klasikiniam keitikliui, t. y. tyrimai buvo atlikti maitinant keitiklį $30 \mathrm{~V}$ maitinimo ịtampa, apkrovus keitiklị reostatu kurio varža $R_{\mathrm{A}}=430 \Omega$. Tyrimai buvo atliekami prie šių keitiklio raktų komutavimo dažnių: 25; 36; 60 ir 
$90 \mathrm{kHz}$, tiriant keitiklio naudingumo koeficiento priklausomybę nuo tiekiamos i apkrovą galios. Tiekiama galia buvo valdoma keičiant impulsų skvarbą $D$ diapazone nuo $0 \mathrm{iki} 48 \%$. Gautos naudingumo koeficiento priklausomybès nuo keitiklio tiekiamos i apkrovą galios prie skirtingų raktų komutavimo dažnio pateiktos 2.7 paveiksle. Iš gautų rezultatų matyti, kad aukščiausias naudingumo koeficientas gaunamas prie $36 \mathrm{kHz}$ raktų komutavimo dažnio, o mažiausias naudojant $90 \mathrm{kHz}$ raktų komutavimo dažnị. Naudingumo koeficientas pradeda stipriai mažèti, kai galia tiekiama ị apkrovą yra mažesné už $70 \mathrm{~W}$. Tuo tarpu naudingumo koeficientas galių diapazone nuo 70 iki $190 \mathrm{~W}$ yra santykinai aukštas ir mažai kinta.

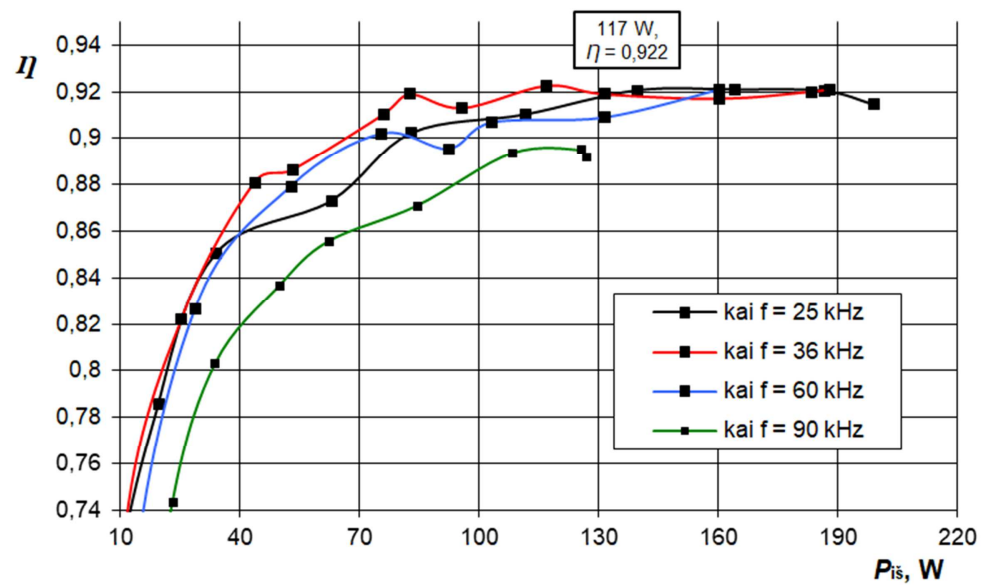

2.7 pav. Keitiklio su alternatyvia aktyviaja viršitampio gesinimo grandine naudingumo koeficiento priklausomybè nuo tiekiamos ị apkrovą galios skirtingiems raktų komutavimo dažniams esant fiksuotai apkrovos varžai $R_{\mathrm{A}}=430 \Omega$

Fig. 2.7. Efficiency dependence of converter with the alternative active overvoltage suppresion on converter output power at various switching frequencies at fixed load resistance $R_{\mathrm{A}}=430 \Omega$

Kitu bandymu buvo tiriama keitiklio naudingumo koeficiento priklausomybė nuo apkrovos galios, keičiant apkrovos varžą $R_{\mathrm{A}}$, esant fiksuotai raktus valdančio IPM signalo skvarbai. Tyrimai atlikti prie šių raktų komutavimo dažnių: 25; 36; 60 ir $90 \mathrm{kHz}$, prie dviejų skvarbos verčių: $D=35 \%$, ir $D=44 \%$. Gauti rezultatai pateikti 2.8 ir 2.9 paveiksluose.

Juose matyti, kad prie $35 \%$ impulsų skvarbos aukščiausia 0,928 keitiklio naudingumo koeficiento vertė pasiekiama esant $36 \mathrm{kHz}$ raktų komutavimo dažniui, tiekiant į apkrovą $159 \mathrm{~W}$ galią. Prie $44 \%$ impulsų skvarbos aukščiausia 0,926 keitiklio naudingumo koeficiento vertè pasiekiama taip pat esant $36 \mathrm{kHz}$ raktų komutavimo dažniui, tiekiant ị apkrovą 159,5 W galią. 


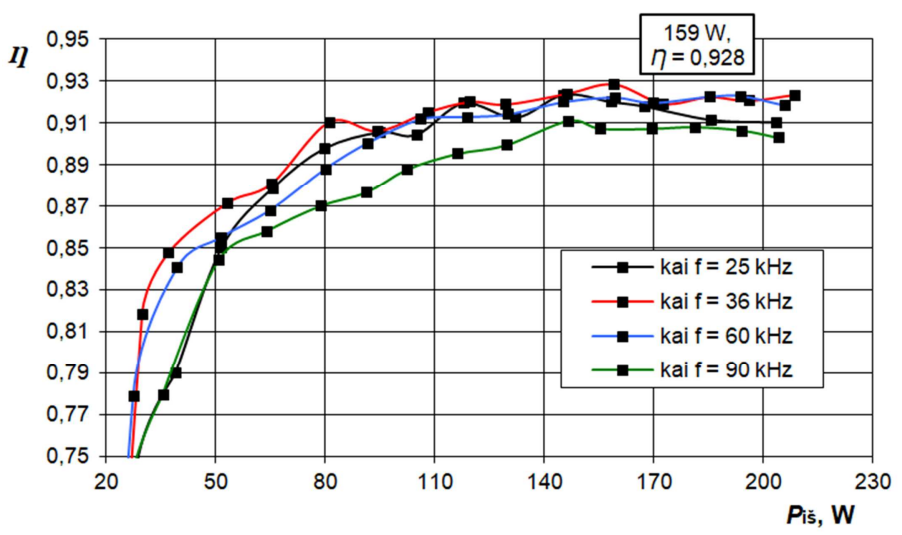

2.8 pav. Keitiklio su alternatyvia aktyviaja viršitampio gesinimo grandine naudingumo koeficiento priklausomybė nuo tiekiamos i apkrovą galios skirtingiems raktų komutavimo dažniams esant fiksuotai impulsų skvarbai $D=35 \%$

Fig. 2.8. Efficiency dependence of converter with the alternative active overvoltage suppresion on converter output power at various switching frequencies at fixed duty cycle $D=35 \%$

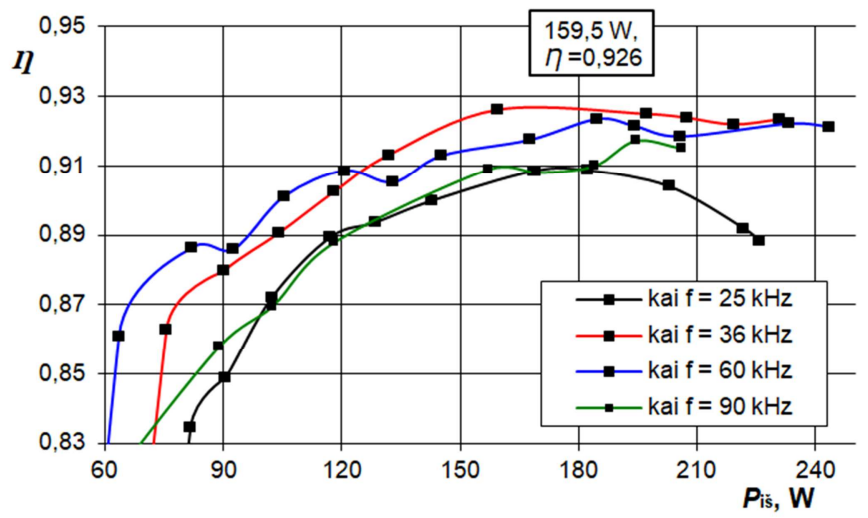

2.9 pav. Keitiklio su alternatyvia aktyviaja viršitampio gesinimo grandine naudingumo koeficiento priklausomybė nuo tiekiamos ị apkrovą galios skirtingiems raktų komutavimo dažniams esant fiksuotai impulsų skvarbai $D=44 \%$

Fig. 2.9. Efficiency dependence of converter with the alternative active overvoltage suppresion on converter output power at various switching frequencies at fixed duty cycle $D=44 \%$

Taip pat matome, kad esant $35 \%$ impulsų skvarbai, $36 \mathrm{kHz}$ raktų komutavimo dažnio taikymas leidžia gauti aukščiausią keitiklio naudingumo koeficientą visame tirtame galių diapazone (2.8 pav.), tuo tarpu esant $44 \%$ 
impulsų skvarbai, kai galia mažesnè nei $125 \mathrm{~W}$, aukštesnis naudingumo koeficientas pasiekiamas prie $60 \mathrm{kHz}$ raktų komutavimo dažnio (2.9 pav.). Matome (2.9 pav.), kad naudojant $25 \mathrm{kHz}$ raktų komutavimo dažni stebimas ryškus keitiklio naudingumo koeficiento mažèjimas kai tiekiama į apkrovą galia viršija $175 \mathrm{~W}$, tuo tarpu prie $35 \%$ impulsų skvarbos naudingumo koeficiento mažèjimas nèra toks ryškus.

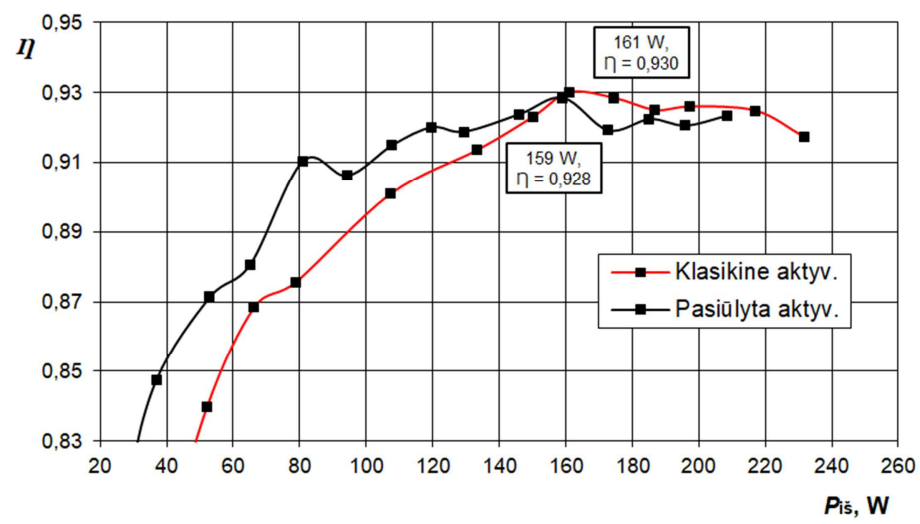

2.10 pav. Keitiklio su alternatyvia aktyviąja viršitampio gesinimo grandine (juoda spalva) ir klasikinio keitiklio (raudona spalva) naudingumo koeficiento priklausomybė nuo tiekiamos į apkrovą galios. Raktų komutavimo dažnis $36 \mathrm{kHz}$; impulsų skvarba $35 \%$

Fig. 2.10. Efficiency dependence of converter with the alternative active overvoltage suppresion (black) and classical converter (red) on output power at $36 \mathrm{kHz}$ switching frequency and $35 \%$ duty cycle

Klasikinio nuolatinès ịtampos grižtamojo keitiklio su aktyviaja viršitampio gesinimo grandine ir siūlomo keitiklio su alternatyvia aktyviaja viršįtampio gesinimo grandine naudingumo koeficientu priklausomybių nuo tiekiamos galios palyginimas pateiktas 2.10 paveiksle. Iš jų matosi, kad keitiklio su alternatyvia viršitampio gesinimo grandine naudingumo koeficientas prie galių mažesnių nei $158 \mathrm{~W}$, yra vidutiniškai $2 \%$ aukštesnis nei klasikinio nuolatinės įtampos grị̌tamojo keitiklio. Aukštesnis keitiklio su alternatyvia viršįtampio gesinimo grandine naudingumo koeficientas pasiektas dèl to, kad pasiūlytas naujas viršịtampio gesinimo grandinès sprendimas leidžia raktui viršįtampio grandinejje naudoti lauko tranzistorius su n tipo kanalu, kurie turi mažesnę atviro tranzistoriaus varžą, lyginant su tranzistoriais su p tipo kanalu, naudojamais klasikiniame keitiklyje. 


\subsection{Dviejų raktų nuolatinės ịtampos grịžtamasis keitiklis}

Pasiūlytas dviejų raktų nuolatinès įtampos grịžtamasis keitiklis skiriasi nuo tradicinių tokio pat tipo keitiklių tuo, kad jame viršitampio energijos grąžinimui i pirmini energijos šaltini nereikia aktyviosios energijos grąžinimo grandinès. Jame taip pat nebereikia slopinti viršitampio papildomais rezistoriniais arba reaktyviaisiais elementais, kurie naudoja papildomą energiją, mažinančią keitiklio naudingumo koeficientą.

\subsubsection{Dviejų raktų nuolatinès ịtampos grįžtamojo keitiklio elektrinè schema ir veikimo principas}

Dviejų raktų nuolatinès ịtampos grị̌tamieji keitikliai paprastai taikomi ịtampos žeminimui, kaip alternatyva tiesioginio tipo keitikliams (Zhao et al. 2007; Bodur et al. 2018; Kim et al. 2016; Hua et al. 2019). Šiame darbe mes siūlome grižtamaji keitiklị naudoti ịtampos aukštinimui, pritaikant ji kuriamam fotovoltiniam mikroinverteriui. Keitiklio elektrinè schema pateikta 2.11 paveiksle. Keitiklį sudaro du tranzistoriniai raktai Q1 ir Q2. Šie raktai dirba sinchroniškai, t. y. jie būna arba abu atviri arba abu uždari, todẻl galima išskirti du darbo ciklus per vieną raktų komutavimo signalo periodą:

1. Atidarius $\mathrm{Q} 1$ ir $\mathrm{Q} 2$ raktų tranzistorius (2.11 pav. a), grịžtamojo transformatoriaus $\mathrm{T} 1$ pirminè apvija prijungiama prie nuolatinès itampos šaltinio (fotovoltinio modulio) ir ja ima tekèti srové $I_{1}$, kaupiama energija transformatoriaus magnetiniame lauke.

2. Uždarius Q1 ir Q2 raktus (2.11 pav. b), atpalaiduojama magnetiniame lauke sukaupta energija indukuojama $i$ antrinę transformatoriaus apviją ir jos sukurta srove per diodą D3 kraunamas kondensatorius C2. Gauta nuolatine įtampa perduodama apkrovai R2. Raktų uždarymo momentu saviindukuotos pirminëje apvijoje viršitampio energijos sukurta srovè $I_{\mathrm{S}}$ diodais D1 ir D2 tiekiama atgal ị maitinimo šaltinị.

Pasiūlytame nuolatinès įtampos grịžtamajame keitiklyje su dvejais raktais viršitampių generuojamą energiją galima gražinti atgal ị nuolatinès ịtampos šaltinį $U_{1}$ tiesiogiai per diodus $\mathrm{D} 1, \mathrm{D} 2$. Dèl šios priežasties viršịtampis sumažinamas iki pirminio maitinimo šaltinio ịtampos $U_{1}$ vertès. Tai leidžia keitiklio raktams Q1, Q2 naudoti lauko tranzistorius su mažesne uždaro tranzistoriaus pramušimo įtampa nei tradiciniuose grịžtamuosiuose keitikliuose, 
nes tradiciniuose keitikliuose raktai yra veikiami papildomai viršitampio ir antrinès įtampos atvaizdo įtampų.

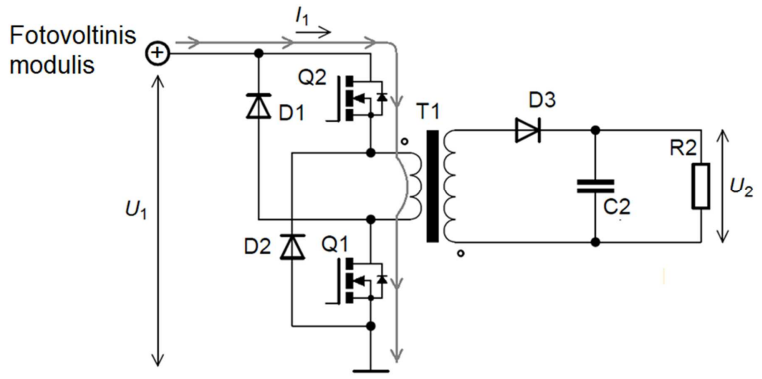

a)

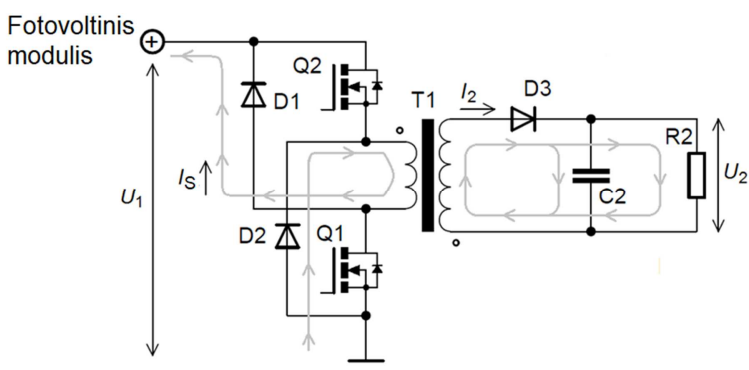

b)

2.11 pav. Nuolatinès ịtampos grižtamojo keitiklio su dvejais raktais elektrinè schema ir transformatoriaus pirminèje ir antrinèje apvijose tekančių srovių kontūrai: a) kontūras, kai raktų Q1, Q2 tranzistoriai atsidaro; b) kontūras, kai raktų Q1, Q2 tranzistoriai užsidaro

Fig. 2.11. Circuit diagram of two-switch DC-DC flyback converter and current flow: a) current flow when switches Q1, Q2 are in state ON; b) current flow when switches $\mathrm{Q} 1, \mathrm{Q} 2$ are in state $\mathrm{OFF}$

Itampa, kuria yra veikiami raktų tranzistoriai klasikiniuose grị̌tamuosiuose keitikliuose galima aprašyti išraiška:

$$
U_{\text {maks. }}=U_{1}+U_{s \mathrm{p}}+U_{2} \frac{n_{1}}{n_{2}},
$$

čia $U_{\text {maks. }}$ - įtampa kuria veikiami raktai; $U_{1}$ - keitiklio įejimo ir $U_{2}-$ išèjimo ìtampos; $U_{\mathrm{sp}}$ - grịžtamojo transformatoriaus magnetinio sklaidos srauto kuriamas viršịtampis; $n_{1}$ ir $n_{2}$ - grižtamojo transformatoriaus pirminès ir antrinès apvijų vijų skaičius.

Galimybė naudoti mažesnès ịtampos raktų tranzistorius ne tik sumažina keitiklio savikainą, bet ir leidžia padidinti keitiklio naudingumo koeficientą, nes žemesnès įtampos lauko tranzistoriai turi mažesnę atviro tranzistoriaus varžą. 
Siūlomo grịžtamojo keitiklio ịtampą aukštinantis transformatorius veikia kaip srovès šaltinis, jeigu ịejimo ir išejjimo įtampos $U_{1}$ ir $U_{2}$ tenkinama sąlygą:

$$
U_{1}>U_{2} \frac{n_{1}}{n_{2}}
$$

jeigu ši sąlyga nèra tenkinama, ịtampos aukštinimo režime grį̌tamasis transformatorius veikia kaip iprastas ịtampos transformatorius - pirminèje apvijoje indukuotas antrinès apvijos ịtampos atvaizdas nukreipiamas atgal $\mathfrak{i}$ maitinimo šaltinį, o antrinè indukuota įtampa priklausys nuo keitiklio maitinimo šaltinio amplitudès ir transformatoriaus apvijų santykio:

$$
U_{2}=U_{1} \frac{n_{2}}{n_{1}}
$$

\subsubsection{Dviejų raktų nuolatinès ịtampos grịžtamojo keitiklio naudingumo koeficiento tyrimas}

Nuolatinès įtampos grịžtamojo keitiklio su dvejais raktais elektrinè schema pateikta 2.11 paveiksle. Fotovoltinis modulis imituojamas įtampos šaltiniu, kurio ịtampa $U_{1}$ yra lygi 2.1. skyriuje atlikto eksperimento su klasikiniu grịžtamuoju keitikliu maitinimo šaltinio įtampai. Keitiklio išejimas apkrautas aktyvine varža R2. Keitiklio komponentų tipai ir parametrai pateikti 2.1 lentelèje.

2.1 lentelè. Dviejų raktų nuolatinès įtampos grịžtamojo keitiklio komponentų tipai ir parametrai

Table 2.1. Types and parameters of two-switch DC-DC flyback converter components

\begin{tabular}{|l|l|l|}
\hline Komponentas & $\begin{array}{l}\text { Komponento } \\
\text { tipas }\end{array}$ & Komponento parametras \\
\hline Q1, Q2 & IRF3205 & $U_{\max }=55 \mathrm{~V} ; I_{\max }=110 \mathrm{~A}$ \\
\hline D1, D2 & MBR1060 & $U_{\max }=60 \mathrm{~V} ; I_{\max }=10 \mathrm{~A}$ \\
\hline D3 & MUR1560 & $U_{\max }=600 \mathrm{~V} ; I_{\max }=15 \mathrm{~A}$ \\
\hline $\mathrm{C} 1$ & Plèvelinis & $0,22 \mu \mathrm{F} ; U_{\max }=400 \mathrm{~V}$ \\
\hline T1 & KA4823-CL & $I_{\mathrm{m}}=28 \mu \mathrm{H} ; I_{1}=0,15 \mu \mathrm{H} ; \mathrm{k}=1: 12$ \\
\hline
\end{tabular}

Eksperimento metu buvo tirta keitiklio naudingumo koeficiento priklausomybė nuo tiekiamos ị apkrovą galios prie ịvairių apkrovos R2 varžų: $330 \Omega ; 660 \Omega ; 990 \Omega$. Galia buvo valdoma keičiant IPM signalo, kuriuo valdomi keitiklio raktų tranzistoriai Q1, Q2, impulsų skvarba, esant fiksuotam IPM 
signalo raktų komutavimo dažniui $f=36 \mathrm{kHz}$. Gauti rezultatai palyginti su klasikinio grižtamojo keitiklio rezultatais, kurio eksperimentinis tyrimas tokiomis pačiomis sąlygomis pakartotas prie $\mathrm{R} 2=660 \Omega$ apkrovimo varžos. Eksperimento rezultatai gauti matuojant keitiklio įèjimo ir išèjimo ịtampą ir srovę, naudojant multimetrus Fluke 8846A. Gauti rezultatai pateikti 2.12 paveiksle.

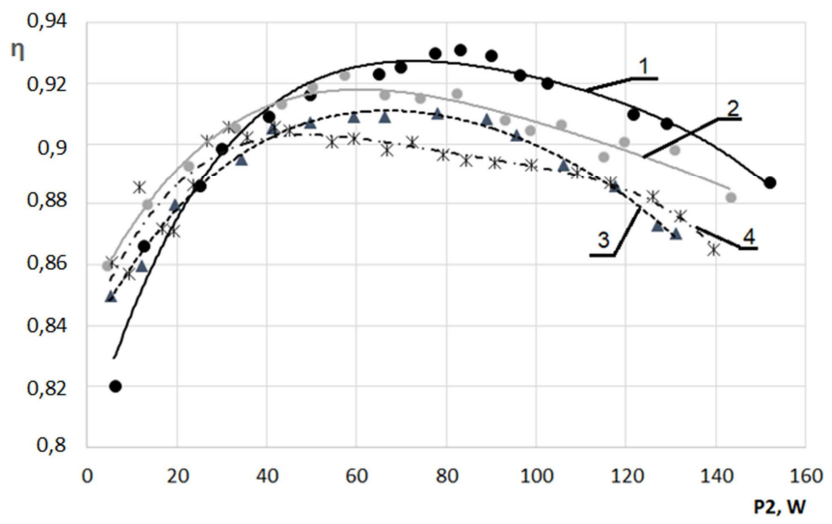

2.12 pav. Dviejų raktų nuolatinès įtampos grį̌tamojo keitiklio naudingumo koeficiento priklausomybè nuo galios tiekiamos ị apkrovą. Eksperimentai atlikti $36 \mathrm{kHz}$ raktų komutavimo dažniui prie šių apkrovos varžų: $1-990 \Omega ; 2-660 \Omega ; 3-330 \Omega$. 4-ta

kreive pateikta priklausomybè klasikiniam grįžtamajam keitikliui, kai apkrovos varža $660 \Omega$

Fig. 2.12. The dependence of two-switch DC-DC flyback converter efficiency on output power at $36 \mathrm{kHz}$ switching frequency and various load resistances: $1-990 \Omega$;

$2-660 \Omega ; 3-330 \Omega$. Curve 4 presents the efficiency dependence of classical DC-DC flyback converter at $660 \Omega$ load resistance

Gautiems naudingumo koeficiento rezultatų priklausomybėms aproksimuoti panaudotas Microsoft Excel daugianaris aproksimacijos metodas. Iš jų matosi, kad keitiklio naudingumo koeficientas prie tos pačios galios tiekiamos i apkrovą didèja didinant apkrovos varžą, t. y. kai keitiklis tą pačią galią pasiekia prie mažesnès srovès. Aukštesnis naudingumo koeficientas šiuo atveju gaunasi todèl, kad galios nuostoliai raktu tranzistoriuose ir grịžtamajame transformatoriuje gaunasi mažesni prie mažesnès srovès. Didžiausia naudingumo koeficiento vertė 0,93 pasiekiama naudojant didžiausią apkrovimo varžą (990 $\Omega$ ), kai ị apkrovą tiekiama $80 \mathrm{~W}$ galia. Naudingumo koeficientas nenukrinta žemiau 0,92, kai galia tiekiama ị apkrovą kinta diapazone nuo 50 iki $105 \mathrm{~W}$.

Pasiūlytas nuolatinès įtampos grižtamasis keitiklis su dvejais raktais turi žymiai aukštesni naudingumo koeficientą už klasikinį nuolatinès ịtampos keitiklį. Pavyzdžiui, siūlomo keitiklio naudingumo koeficientas prie $80 \mathrm{~W}$ 
galios, kai apkrovos varža $\mathrm{R} 2=660 \Omega$, siekia 0,918 , tuo tarpu klasikinio 0,895 , t. y. $2,3 \%$ didesnis.

Lyginant su patobulintu klasikiniu keitikliu su alternatyvia viršįtampio gesinimo grandine, keitiklis su dvejais raktais turi panašų naudingumo koeficientą 100-120 W galių diapazone, o 120-150 W galių diapazone maždaug $2 \%$ mažesnį. Tačiau keitiklis su dvejais raktais turi 15-2,2\% aukštesnị naudingumo koeficientą kai galia kinta 10-70 W diapazone. Naudingumo koeficientas mažesnių galių diapazone yra svarbesnis nei prie didesnès nei $120 \mathrm{~W}$ galios, nes modulis nominalią galią, nurodytą jo techninèse charakteristikose, tiekia idealiu atveju, esant giedram orui, kai saulè yra zenite. Realiai, didžiausią laiko dalị, dèl debesuotumo ir todèl kad saulès spinduliai krinta ne vertikaliai i modulio paviršių, modulis tiekia apie 10-20\% nominalios galios (H. Abunima), t. y. 25-50 W.

Gautos priklausomybės nèra monotoniškos ir turi maksimumus. Tokị priklausomybių pobūdị sąlygoja du faktoriai, stipriai ịtakojantys naudingumo koeficientą. Keitikliui veikiant maža galia, jo naudingumo koeficientą apsprendžia rakto komutacijos nuostoliai, kurie nuo galios mažai priklauso, todèl keitikliui veikiant didesne galia komutacinių nuostolių itaka mažèja ir naudingumo koeficientas auga, tačiau vis didesnę ịtaką pradeda daryti transformatoriaus vario ir raktų atvirojo tranzistoriaus laidumo nuostoliai, todèl keitikliui veikiant prie didesnių galių naudingumo koeficientas ima vèl mažèti.

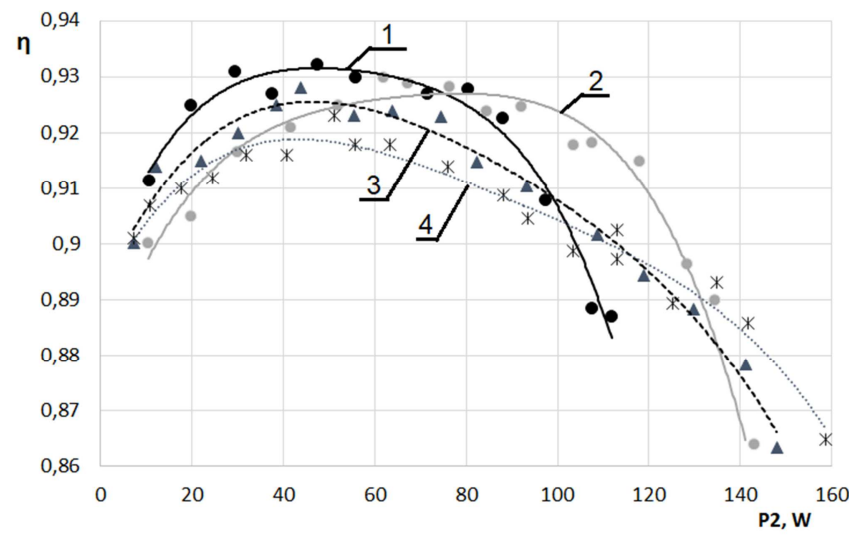

2.13 pav. Dviejų raktų nuolatinès įtampos grižtamojo keitiklio naudingumo koeficiento priklausomybè nuo galios tiekiamos ị apkrovą. Eksperimentai atlikti $430 \Omega$ apkrovos varžai prie šių raktų komutavimo dažnių: $1-25 \mathrm{kHz} ; 2-36 \mathrm{kHz} ; 3-60 \mathrm{kHz}$; $4-90 \mathrm{kHz}$

Fig. 2.13 The dependence of two-switch DC-DC flyback converter efficiency on output power at $430 \Omega$ converter load resistance for the following switching frequencies:

$$
1-25 \mathrm{kHz} ; 2-36 \mathrm{kHz} ; 3-60 \mathrm{kHz} .4-90 \mathrm{kHz}
$$


Kitu bandymu tiriama raktų komutavimo dažnio ịtaka nuolatinès įtampos grịžtamojo keitiklio su dvejais raktais naudingumo koeficientui. Tuo tikslu tiriamos naudingumo koeficiento priklausomybès nuo galios tiekiamos ị apkrovą prie šių raktų komutavimo dažnių: $25,36,60,90 \mathrm{kHz}$, kai apkrova R2 = $430 \Omega$. Gautos priklausomybės pateiktos 2.13 paveiksle. Iš gautų rezultatų matome, kad maksimali naudingumo koeficiento vertè 0,932 pasiekiama prie $25 \mathrm{kHz}$ raktų komutavimo dažnio ir $50 \mathrm{~W}$ išèjimo galios. Tačiau prie $36 \mathrm{kHz}$ dažnio gauname aukštesni naudingumo koeficientą prie didesnių galių. Pavyzdžiui, naudingumo koeficientas esant $25 \mathrm{kHz}$ raktų komutavimo dažniui, pradeda stipriai mažèti viršijus $80 \mathrm{~W}$ galią, tuo tarpu prie $36 \mathrm{kHz}$ - viršijus $110 \mathrm{~W}$. Didžiausia naudingumo koeficiento vertè pasiekiama prie $36 \mathrm{kHz}$ yra 0,928 ir ji yra gaunama prie $80 \mathrm{~W}$ apkrovos galios. Prie aukštesnių 60 ir $90 \mathrm{kHz}$ raktų komutavimo dažnio naudingumo koeficientas yra mažesnis dèl didesnių komutacinių nuostolių raktų tranzistoriuose Q1, Q2.

Atlikti šiame skyriuje eksperimentiniai nuolatinės įtampos aukštinančiụjų keitiklių, skirtų fotovoltiniams mikroinverteriams, tyrimai parode kad pasiūlytas grịžtamasis keitiklis su dvejais raktais turi aukštesnị naudingumo koeficientą, visame tirtu galių diapazone lyginant su klasikiniu keitikliu bei didesni 10-70 W galios diapazone, lyginant su patobulintu klasikiniu keitikliu. Taip pat grịžtamasis keitiklis su dvejais raktais turi mažiau komponentų, lyginant su klasikiniu bei patobulintu klasikiniu keitikliu. Dèl minètų priežasčių, mikroinverteris buvo kuriamas naudojant dviejų raktų nuolatinès įtampos grịžtamaji keitiklị.

\subsection{Vienos pakopos mikroinverteris, sudarytas iš dviejų raktụ grižtamụjų keitiklių}

Naudojant du dviejų raktų grịžtamuosius keitiklius, sukurtas energetiškai efektyvus vienos pakopos mikroinverteris. Nuo žinomų vienos pakopos mikroinverteriu jis skiriasi antrinejje grižtamojo transformatoriaus apvijoje naudojamų raktų, skirtų sinusoidinès įtampos suformavimui iš teigiamo ir neigiamo įtampos pusperiodžių, sprendimu ir tuo, kad jo realizavimui panaudotas naujas, 2.3 poskyryje pasiūlytas, dviejų raktų grįžtamasis nuolatinès itampos keitiklis. Šiame skyriuje aprašytas šio mikroinverterio principas bei pateikti jo eksperimentinių tyrimų ir matematinio modeliavimo rezultatai. 


\subsubsection{Vienos pakopos mikroinverterio, sudaryto iš dviejų raktų grịžtamųjų keitiklių, elektrinè schema ir veikimo principas}

Siūlomo mikroinverterio elektrinè schema pateikta 2.14 paveiksle. Jị sudaro du priešinga faze veikiantys, 2.3 poskyryje analizuoti, dviejų raktų grįžtamieji ịtampos keitikliai. Vieną keitikli sudaro raktai Q1, Q4, kitą - Q2, Q3. Tam kad būtų formuojama sinuso formos ittampa, keitiklių raktai yra valdomi IPM signalu, moduliuojant impulsų trukmę sinuso dèsniu. Raktų valdymo signalai pateikti 2.15 paveiksle. Vienas keitiklis formuoja teigiamą, kitas - neigiamą ịtampos pusperiodi, t. y. kai vienas keitiklis formuoja įtampos pusperiodi kito keitiklio raktai yra uždari. Kitaip sakant, mikroinverterị sudaro du grįžtamieji ịtampos keitikliai, naudojantys tą patị grịžtamajị transformatorių. Sinuso formos įtampos formavimui iš ịtampos pusperiodžių ir jų tiekimui ị apkrovą, antrinejje grị̌tamojo transformatoriaus apvijoje naudojamas autoriaus pasiūlytas sprendimas, kuris realizuojamas raktais Q5, Q6 ir diodais D1, D2. Teigiamas pusperiodis tiekiamas per atvirą raktą Q5 ir diodą D1 (raktas Q6 uždarytas), o neigiamas pusperiodis tiekiamas per atvirą raktą Q6 ir diodą D2 (raktas Q5 uždarytas). Transformatoriaus magnetinio lauko nuotékio sukurti viršįtampiai, generuojami tranzistorių Q1-Q4, uždarymo momentu, gražinami i maitinimo šaltinį diodais, kurie yra raktų, naudojamų mikroinverteryje, konstrukcijos dalis. Dèl šios priežasties nebereikia naudoti atskirų diodų viršįitampių gražinimui ị mikroinverterio maitinimo šaltinį. Mikroinverterio maketas parodytas 2.16 paveiksle.

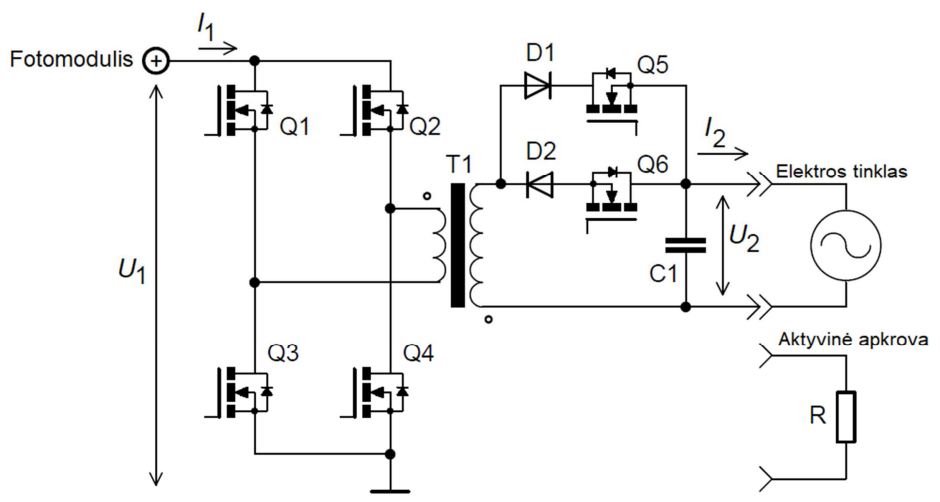

2.14 pav. Vienos pakopos mikroinverterio, sudaryto iš dviejų raktų grižtamụjų keitiklių, elektrinè schema

Fig 2.14. Circuit diagram of single stage microinverter based on couple of two switch flyback converters 

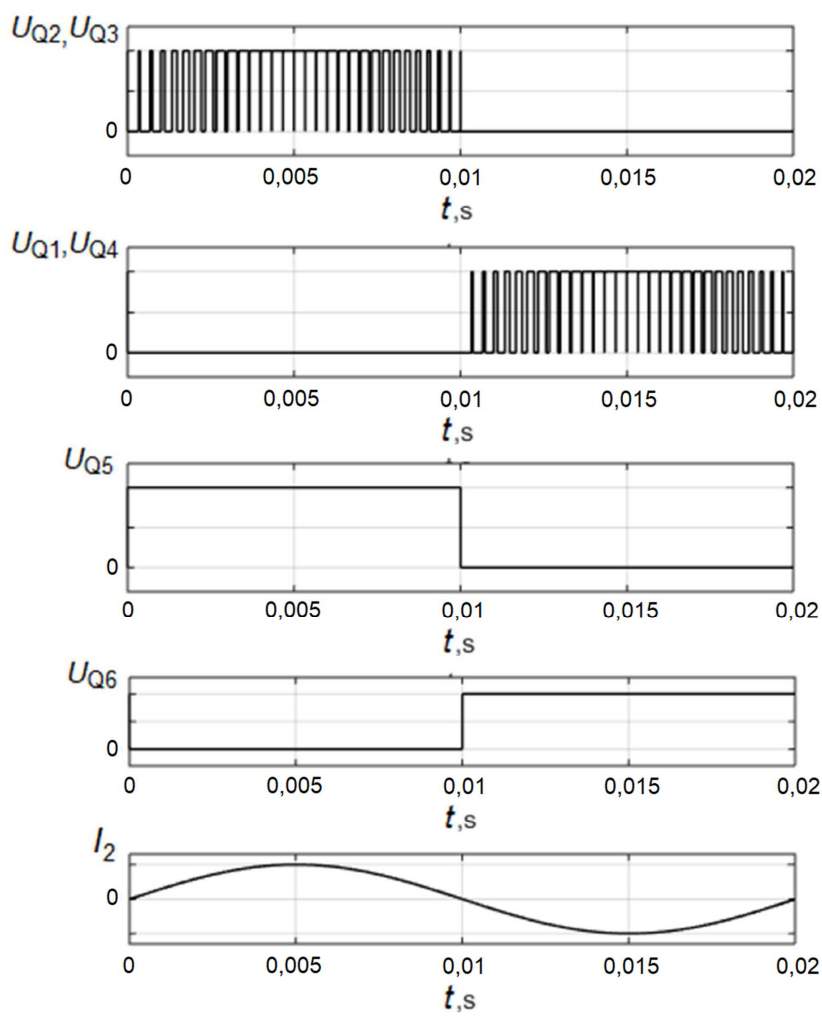

2.15 pav. Vienos pakopos mikroinverterio, sudaryto iš dviejų raktų grịžtamujjų keitiklių, raktų valdymo signalai

Fig. 2.15. Control signals of switch transistors of single stage microinverter based on couple of two switch flyback converters

2.2 lentelè. Mikroinverterio pagrindinių komponentų tipai ir parametrai Table 2.2. Types and parameters of microinverter main components

\begin{tabular}{|l|l|l|}
\hline Elektronikos komponentas & Tipas & Parametrai \\
\hline Q1, Q2, Q3, Q4 & IRF3205 & 55 V; 110 A \\
\hline Q5, Q6 & 2SK2717 & 900 V; 5 A \\
\hline D1, D2 & FUF5408 & $1000 \mathrm{~V} ; 3 \mathrm{~A}$ \\
\hline C1 & Plèvelinis & $0,22 \mu \mathrm{F} ; 400 \mathrm{~V}$ \\
\hline T1 & KA4823-CL & $\mathrm{I}_{\mathrm{m}}=28 \mu \mathrm{H} ; \mathrm{I}_{1}=0,15 \mu \mathrm{H} ; \mathrm{k}=1: 12$ \\
\hline
\end{tabular}




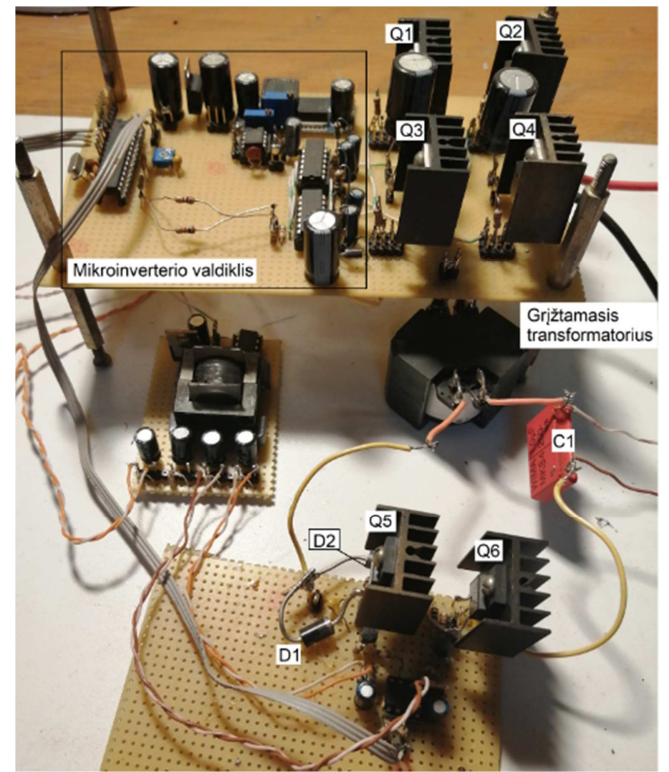

2.16 pav. Vienos pakopos mikroinverterio, sudaryto iš dviejų raktų grịžtamųjų keitiklių, maketas

Fig. 2.16. Experimental test bench of a of single stage microinverter based on couple of two switch flyback converters

Vienos pakopos mikroinverterio, sudaryto iš dviejų raktų grįžtamujų keitiklių, pagrindinių elektronikos komponentų tipai ir parametrai pateikti 2.2 lentelèje.

\subsubsection{Vienos pakopos mikroinverterio, sudaryto iš dviejų raktų grịžtamụjų keitiklių, naudingumo koeficiento tyrimas}

Vienos pakopos mikroinverteris, sudarytas iš dviejų raktų grịžtamujų keitiklių, buvo tiriamas eksperimentiškai šiais režimais:

1. Veikiant autonominiu režimu, kai energija tiekiama i aktyvinę apkrovą.

2. Jungiant prie elektros tinklo, kai energija tiekiama ị tinklą.

Tiriant mikroinverterị autonominiu režimu, jis buvo apkrautas aktyvinę 330 ir $860 \Omega$ apkrova. Buvo tiriama mikroinverterio naudingumo koeficiento priklausomybė nuo tiekiamos i apkrovą galios. Taip pat buvo tiriami mikroinverterio išèjimo ịtampos netiesiniai iškraipymai. Mikroinverterio tiekiama galia $\mathfrak{i}$ aktyvinę apkrovą buvo valdoma keičiant SIPM signalo, kuriuo 
valdomi keitiklio raktai Q1-Q4, impulsų skvarbą, esant fiksuotam SIPM signalo raktų komutavimo dažniui $f=36 \mathrm{kHz}$.

Tiekiama ị mikroinverteri galia buvo matuojama Fluke 8846A multimetrais (paklaida ne didesnè kaip $0,1 \%$ ), antrinèje grandinèje - galios analizatoriumi Siemens SENTRON PAC3200 (paklaida ne didesnè kaip 0,5\%). Gautos naudingumo koeficiento priklausomybès nuo galios tiekiamos $\mathfrak{i}$ apkrovą pateiktos 2.17 paveiksle.

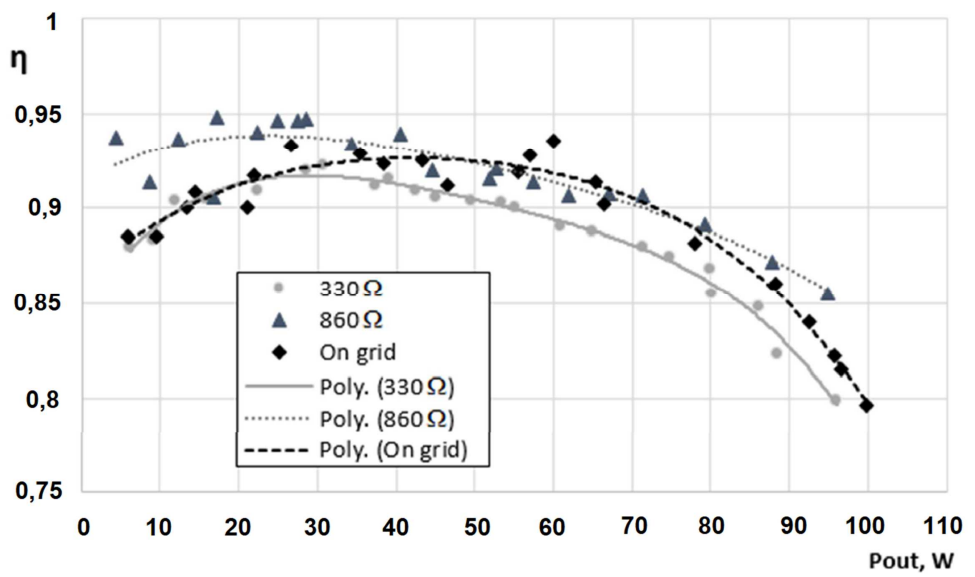

2.17 pav. Vienos pakopos mikroinverterio, sudaryto iš dviejų raktų grį̌ztamụjų keitiklių, naudingumo koeficiento priklausomybè nuo tiekiamos ị apkrovą galios, kai mikroinverteris veikia energetinès salos režimu ir kai tiekia energiją ị elektros tinklą Fig. 2.17. Dependence of the single stage microinverter based on couple of two switch flyback converters efficiency on output power in on-grid and off-grid operating modes

Iš gautų rezultatų (2.17 pav.) matosi, kad inverteriui veikiant salos režimu aukštesnis naudingumo koeficientas gaunamas prie didesnès apkrovos varžos

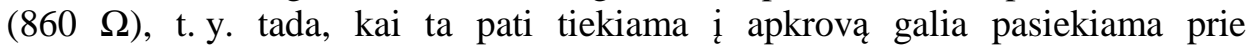
aukštesnès mikroinverterio įtampos ir mažesnès srovès. Taip atsitinka todèl, kad esant mažesnei srovei gaunami mažesni energijos nuostoliai raktų tranzistoriuose ir grị̌tamajame transformatoriuje. Maksimalus išmatuotas naudingumo koeficientas veikiant mikroinverteriui salos režimu siekia 0,95 prie $860 \Omega$ apkrovos, esant $28 \mathrm{~W}$ galiai tiekiamai ị apkrovą.

Veikiant mikroinverteriui tinklo režimu, maksimalus išmatuotas naudingumo koeficientas siekia 0,94 , kai ị elektros tinklą tiekiama $45 \mathrm{~W}$ galia. Mikroinverterio naudingumo koeficientas nenukrinta žemiau 0,9, kai galia kinta nuo 15 iki $70 \mathrm{~W}$. Prie mažesnių galių naudingumo koeficientas mažèja dèl galios raktų komutacijos nuostolių. Naudingumo koeficientas prie didesnių galių mažèja taip pat, nes dèl padidèjusios srovès išauga laidumo nuostoliai raktų tranzistoriuose ir grį̌tamajame transformatoriuje. 


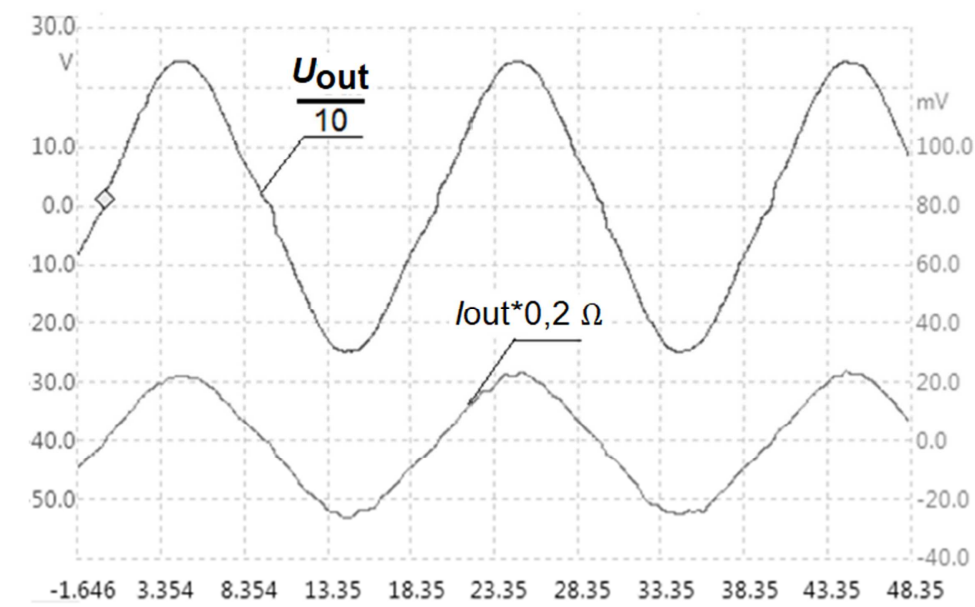

2.18 pav. Vienos pakopos mikroinverterio, sudaryto iš dviejų raktų grị̌tamụjų keitiklių, išèjimo įtampa (skalè kairèje) ir srovè (skalè dešinėje), keitikliui veikiant salos režimu. IPM įtampos raktų komutavimo dažnis $36 \mathrm{kHz}$, mikroinverterio apkrovos varža $860 \Omega$ Fig. 2.18. Output voltage (scale on the left) and current (scale on the right) waveforms of the single stage microinverter based on couple of two switch flyback converters for the situation when microinverter operates in off-grid mode at $36 \mathrm{kHz}$ switching frequency and is loaded by the $860 \Omega$ resistive load

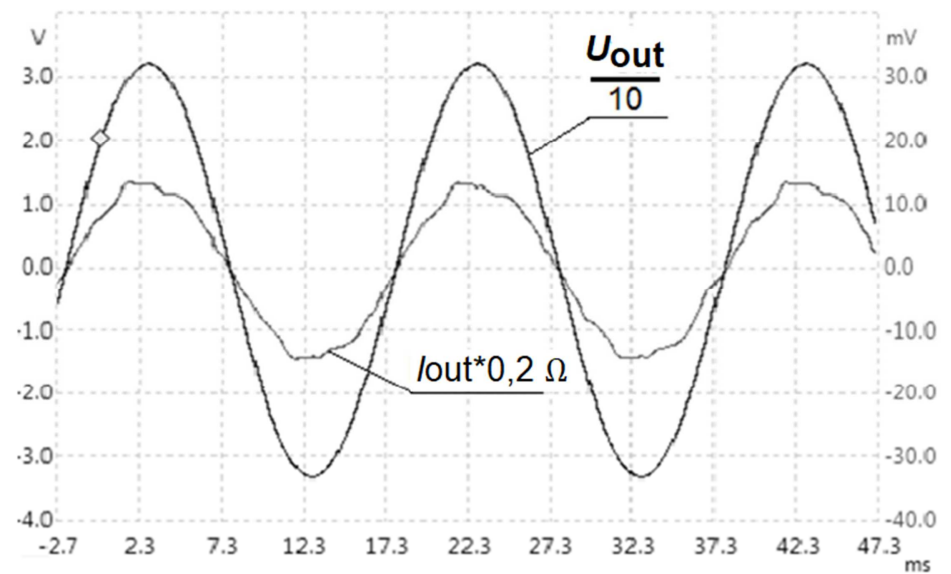

2.19 pav. Vienos pakopos mikroinverterio, sudaryto iš dviejų raktų grịžtamụjų keitiklių, išèjimo ịtampa (skalè kaireje) ir srovè (skalè dešinèje), keitikliui veikiant tinklo režimu.

IPM įtampos raktų komutavimo dažnis $36 \mathrm{kHz}$

Fig. 2.19 Output voltage (scale on the left) and current (scale on the right) waveforms of single stage microinverter based on couple of two switch flyback converters for the situation when microinverter operates in grid-tied mode at $36 \mathrm{kHz}$ switching frequency 
Mikroinverterio generuojamos ịtampos ir tiekiamos $\mathfrak{i}$ apkrovą srovès stebejjimui bei netiesinių iškraipymų matavimui buvo naudojamas oscilografas PicoScope 4223.

Salos režime veikiančio mikroinverterio ịtampa ir srovė pavaizduotos 2.18 paveiksle. Srové buvo matuojama naudojant $0,2 \Omega$ šuntą, ịtampa matuojama naudojant 1:10 ịtampos daliklị. Mikroinverteris buvo apkrautas $860 \Omega$ aktyvine apkrova. Išmatuoti įtampos netiesiniai iškraipymai sudare 4,4 \%. Iš 2.18 paveikslo matyti, kad didžiausi ịtampos iškraipymai gaunami kai įtampos vertè pereina per nulį. Šie iškraipymai atsiranda dèl to, kad abiejų raktų tranzistoriai, juos perjungiant, tranzistorių saugumui užtikrinti, yra mažai trukmei (angl. dead time) uždaromi.

Tinklo režimu veikiančio mikroinverterio ịtampa ir srovė pateikta 2.19 paveiksle. Srové buvo matuojama naudojant $0,2 \Omega$ šuntą, ịtampa matuojama naudojant 1:100 ịtampos daliklį. Veikiant mikroinverteriui tinklo režimu, svarbūs yra tiekiamos ị tinklą srovès netiesiniai iškraipymai. Jie sudaré $11,2 \%$. Didžiausi srovès iškraipymai gauti srovès fazei pereinant per nulị, kai abu tranzistoriai Q5 ir Q6 yra uždaromi Taip pat srovès iškraipymai stebimi srovei pasiekus $60 \%$ amplitudinès vertès. Tokį srovès iškraipymą lemia keitiklio srovès formos valdymo sistemos netobulumas.

\subsection{Antrojo skyriaus išvados}

1. Patobulinto nuolatinès ịtampos keitiklio su alternatyvia aktyvine viršitampio gesinimo grandine naudingumo koeficientas yra 2-3\% didesnis už klasikinio, kai galia neviršija 160 W. Didesnis naudingumo koeficientas pasiektas dèl pasiūlytos efektyvesnès viršitampio gesinimo grandinès ir todèl, kad keitiklio raktų Q1 ir Q3 igyvendinimui panaudoti $\mathrm{n}$ tipo kanalo lauko tanzistoriai, turintys mažesnę atviro tranzistoriaus varžą, lyginant su p tipo kanalo tranzistoriais.

2. Sukurtas dviejų raktų nuolatinès ịtampos grịžtamasis keitiklis, lyginant su klasikiniu, turi mažiau elektronikos komponentų, naudojamas paprastesnis lauko tranzistorių valdymas.

3. Pasiūlytas dviejų raktų nuolatinès įtampos grižtamasis keitiklis turi žymiai aukštesnị naudingumo koeficientą už klasikini nuolatinès įtampos keitiklị. Siūlomo keitiklio naudingumo koeficientas prie $80 \mathrm{~W}$ galios, kai apkrovos varža $\mathrm{R} 2=660 \Omega$, siekia 0,918 , tuo tarpu klasikinio $-0,895$, t. y. 2,3\% didesnis. 
4. Lyginant su patobulintu klasikiniu keitikliu su alternatyvia viršitampio gesinimo grandine, dviejų raktų keitiklis turi panašų naudingumo koeficientą 100-120 W galių diapazone, Tačiau keitiklis su dvejais raktais turi $15-2,2 \%$ aukštesni naudingumo koeficientą kai galia kinta 10-70 W diapazone.

5. Sukurto vienos pakopos mikroinverterio didžiausias išmatuotas naudingumo koeficientas, veikiant mikroinverteriui salos režimu, siekia 0,95 prie $860 \Omega$ apkrovos varžos ir $36 \mathrm{kHz}$ komutavimo dažnio, kai galia tiekiama ị apkrovą $28 \mathrm{~W}$. Veikiant mikroinverteriui tinklo režimu, maksimalus išmatuotas naudingumo koeficientas siekia 0,94 , kai ị elektros tinklą tiekiama $45 \mathrm{~W}$ galia. 


\section{Mikroinverterio valdymo sistemos kūrimas ir elementų parametrų ịtakos mikroinverterio energetiniam efektyvumui tyrimas}

Šiame skyriuje sprendžiama ị elektros tinklą tiekiamos mikroinverterio srovès valdymo problema. Pateikti vienos pakopos mikroinverterio, sudaryto iš dviejų raktų grịžtamųjų keitiklių, srovès valdymo sistemos, naudojant proporcinị integralinị (PI) ir siūlomą PI valdiklį su keičiamu laike proporciniu koeficientu, tyrimo rezultatai. Taip pat pateikti elementu parametru ịtakos mikroinverterio energetiniam efektyvumui analizès rezultatai. Gauti rezultatai paskelbti keturiose publikacijose (Bielskis et al. 2020; Iysaouy \& Bielskis et al 2018a; Iysaouy \& Bielskis et al 2018b; Bielskis et al. 2016a) ir pristatyti keturiose konferencijose. Atliktais tyrimais buvo sprendžiamos mikroinverterio tiekiamos ị tinklą srovès kokybès ir mikroinverterio energetinio efektyvumo gerinimo problemos. 


\subsection{Mikroinverterio srovès valdymo sistemos kūrimas ir tyrimas}

Tinklo mikroinverteris tiekia elektros energiją i elektros tinklą veikdamas srovės šaltinio režimu. Vienas iš pagrindinių reikalavimų yra išlaikyti tiekiamos srovès sinuso formą (Xin et al. 2017; Kojabadi et al. 2006; Nan et al. 2017; Suzuki et al. 2019; Xia et al. 2017). Aukštesniosios harmonikos gali būti slopinamos naudojant tradicinius LC filtrus. Tačiau pasyvūs filtrai nèra veiksmingi pašalinant harmonikas ( $\mathrm{Na}$ et al. 2018; Wang et al. 2019; Popescu et al 2018; Lee et al. 2016; Kazmierkowski et al 1998). Veiksmingiau yra naudoti grižtamojo ryšio valdymo sistemą mikroinverterio srovès sinuso dèsnio valdymui. Tam tikslui ị mikroinverterio struktūrą turi būti ịterpta sinuso dèsnio sekimo sistema, kuri leistų valdyti ị mikroinverterio raktus tiekiamų IPM signalų parametrus taip, kad mikroinverterio išejimo srovès forma atkartotų atraminio sinuso signalo formą ir fazę (Rajeev et al. 2018; Motta et al 2016; Xin et al 2017; Bayhan et al. 2019; Zha et al 2017). Populiariausi valdikliai, naudojami tinklo keitiklių išejimo srovei sekti yra proporcinis integralinis (PI) (Dash et al. 2011; Kamil et al 2019; Gazoli et al. 2012; Hlali et al 2019; Sahu et al 2016), proporcinis integralinis diferencialinis (PID) (Yongjun et al. 2017; Gazoli et al. 2012; Chang-liang et al. 2014; Wang et al. 2013) ir proporcinis rezonansinis (PR) (Caiza et al. 2018; Motta et al. 2016; Gazoli et al. 2012; Melo et al. 2017; Rodriguez et al 2011; Shen et al. 2010; Liserre et al 2006; Zhang et al 2014) valdikliai. Tačiau labiau sudètingi atspejjantieji (angl. predictive) valdikliai taip pat gali būti naudojami (Bode et al. 2005; Jayalath et al 2015; Kojabadi et al. 2006) mikroinverterio srovès valdymo sistemoje.

Paprastai pramoniniuose mikroinverteriuose yra naudojami PI ir PID valdikliai (Rodriguez et al. 2011). Šių valdiklių populiarumą lemia lengvas diegimas ir gerai išplètotos valdiklio parametrų derinimo metodikos (Gazoli et al. 2012). PI ir PID valdiklių trūkumas yra tai, kad jie negali sekti sinuso atskaitos signalo išvengiant nusistovejjusio režimo paklaidos (angl. steady-state error).

Skyriuje aprašomas disertanto pasiūlytas naujas PI valdiklis su keičiamu laike proporciniu koeficientu. Pateikti mikroinverterio srovès valdymo sistemos su sukurtu valdikliu tyrimo rezultatai. Gautų rezultatų palyginimui, ištirta valdymo sistema naudojant klasikinị PI valdiklį. Tyrimai atlikti naudojant modeliavimą ir eksperimentiškai. 


\subsubsection{Mikroinverterio srovès valdymo sistema su proporciniu integraliniu valdikliu}

Vienos pakopos mikroinverterio, sudaryto iš dviejų raktų grįžtamųjų keitiklių, struktūrinè schema, sudaryta naudojant Matlab/Simulink programą, pateikta 3.1 paveiksle. Mikroinverterio srovès valdymo sistema pateikta 3.2 paveiksle. Joje pateikiama grịžtamojo ryšio valdymo sistema, skirta sekti sinuso formos nuostato signalą. IPM signalą mikroinverterio raktų valdymui formuoja analoginių signalų komparatorius, kuris palygina valdiklio išèjimo signalą su pjūklo formos signalu. Momentinę suformuoto IPM signalo skvarbą galima rasti naudojant išraišką:

$$
D_{\mathrm{IPM}}=\frac{u\left(t_{\mathrm{i}}\right)}{U_{\mathrm{Ast}}},
$$

čia $U\left(t_{\mathrm{i}}\right)$ - valdiklio išèjimo signalas laiko momentu $t_{\mathrm{i}}, U_{\mathrm{Ast}}$-pjūklinès įtampos amplitudè. Signalai turi tenkinti sąlygą $U\left(t_{\mathrm{i}}\right) \leq U_{\text {Ast }}$.

Srovès aukšto dažnio pulsacijų ịtakai mikroinverterio darbo stabilumui sumažinti, srovès grižtamojo ryšio grandinejje panaudotas žemųjų dažnių filtras (1-st order filter 3.2 pav.). Mikroinverterio valdymo sistemos veikimas turi būti sinchronizuotas su elektros tinklu, todèl valdymo sistemoje yra stebima tinklo ịtampos fazès perèjimas per nulinę vertę (Voltage feedback 3.2 pav). Komparatoriaus suformuotas IPM signalas elektros tinklo ịtampos teigiamo pusperiodžio metu yra paduodamas į HF1 gnybtą ir yra naudojamas raktų Q2, Q3 valdymui (tuo metu raktų tranzistoriai Q1, Q4 yra uždaryti). Taip pat teigiamo pusperiodžio metu i LF1 gnybtą paduodamas raktą Q5 atidarantis signalas (3.1 pav.). Neigiamo elektros tinklo įtampos pusperiodžio metu IPM signalas paduodamas i HF2 gnybtą (i raktus Q1, Q4), o signalas, atidarantis tranzistorių Q6 - i gnybtą LF2. Raktų tranzistoriai Q2, Q3 ir Q5 yra uždaryti neigiamo pusperiodžio metu.

Buvo tiriama mikroinverterio valdymo sistema (3.2 pav.) su klasikiniu PI valdikliu, kurio valdymo algoritmas aprašomas išraiška:

$$
U(t)=K_{\mathrm{P}} e(t)+K_{\mathrm{I}} \int_{t_{0}}^{t} e(t) \mathrm{d} t,
$$

čia $K_{\mathrm{P}}$ ir $K_{\mathrm{I}}$ - proporcinis ir integralinis koeficientai, $t$ - laikas, $t_{0}$ - pradinis laiko momentas; $e$ - valdymo paklaida, kurios signalas tiekiamas ị valdiklio ịejimą. 


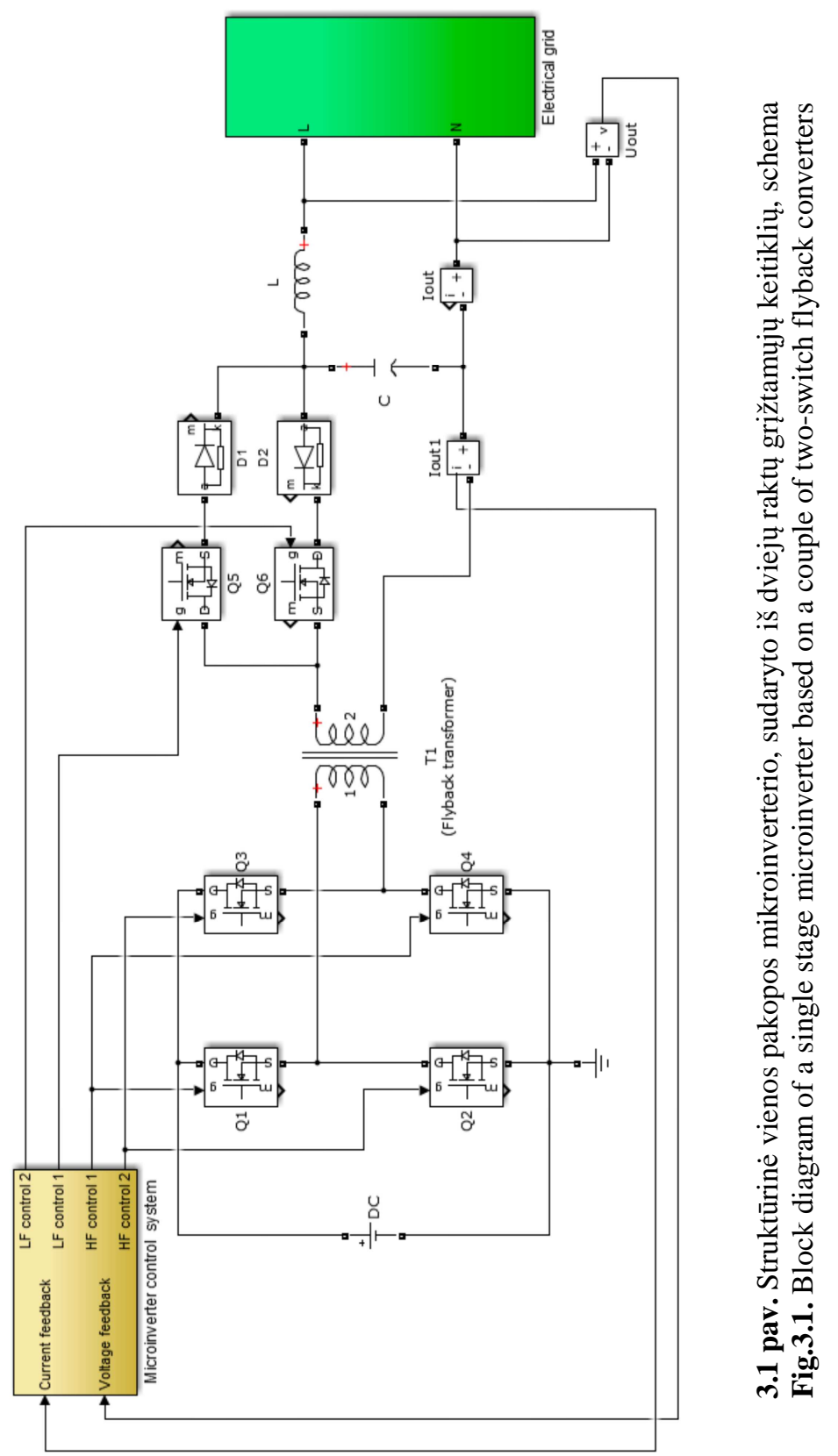




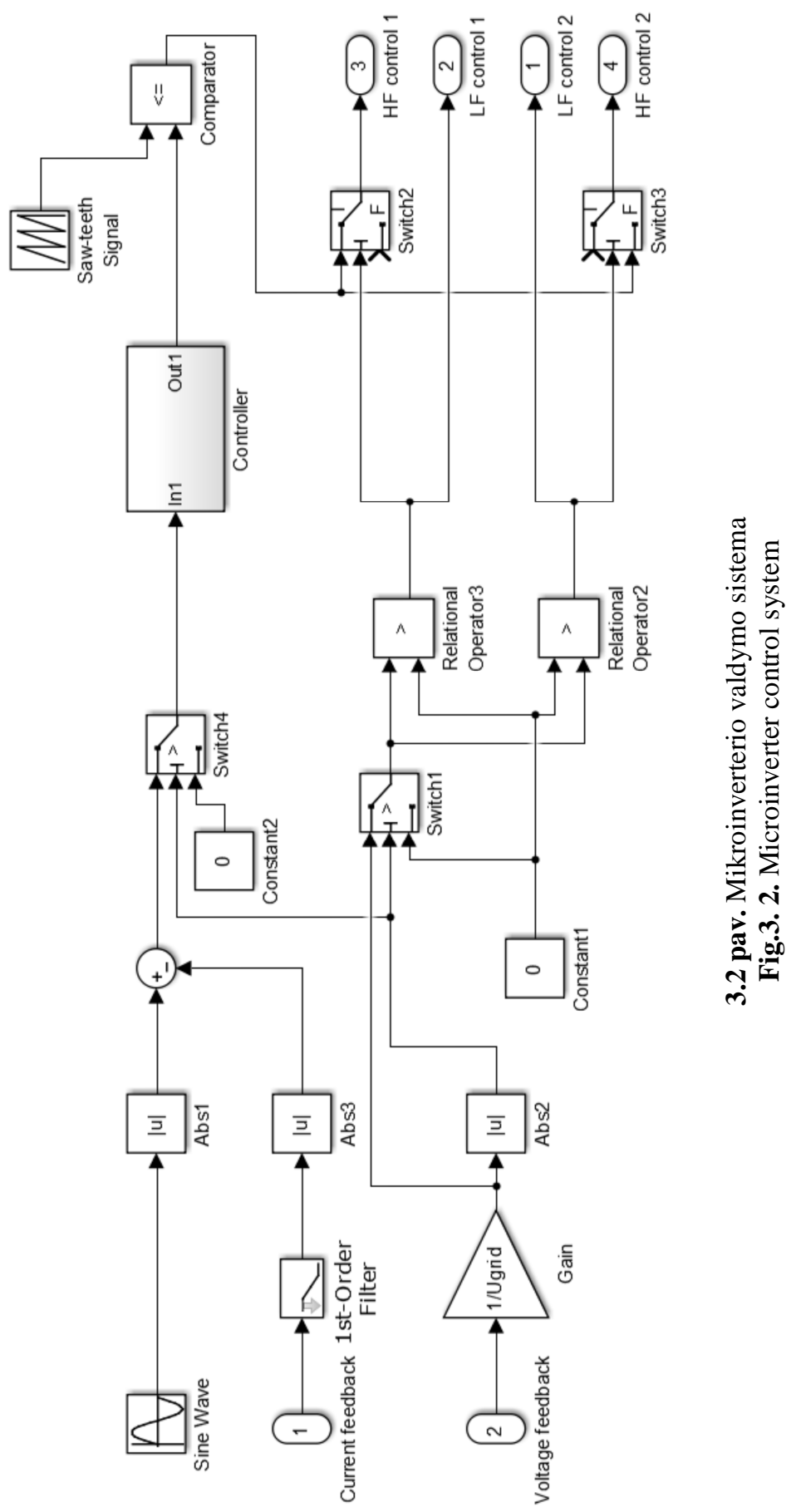


Mikronverterio valdymo sistema turi palaikyti mikroinverterio išèjimo srovès sinuso formą, palyginant ją su atraminiu sinuso formos signalu. Inverterio srovès fazè turi sutapti su maitinimo tinklo ịtampos faze. Ištirtos inverterio valdymo sistemos veikimas priklauso ne tik nuo valdiklio valdymo algoritmo, bet ir nuo grįžtamojo transformatoriaus apvijų aktyvinès varžos ir induktyviosios varžos bei įmagnetinančiojo induktyvumo. Taip pat jis priklauso ir nuo mikroinverterio išèjime esančio CL filtro parametrų.

Grịžtamojo transformatoriaus ir CL filtro elementų parametrai pateikti 3.1 lentelèje.

3.1 lentelè. Grịžtamojo transformatoriaus ir CL filtro elementų parametrai Table 3.1. Parameters of flyback transformer and CL filter

\begin{tabular}{|l|l|l|}
\hline Komponentas & Parametras & Verte் \\
\hline \multirow{4}{*}{$\begin{array}{l}\text { Grįžtamojo } \\
\text { transformatorius }\end{array}$} & Induktyvumas, $\mu \mathrm{H}$ & 36 \\
\cline { 2 - 3 } & Pirminės apvijos aktyvinè varža, $\Omega$ & 0,01 \\
\cline { 2 - 3 } & Antrinès apvijos aktyvinè varža, $\Omega$ & 0,47 \\
\cline { 2 - 3 } & Transformavimo koeficientas & $1: 12$ \\
\hline CL filtro kondensatorius & Talpa, $\mathrm{nF}$ & 200 \\
\hline CL filtro droselis & Induktyvumas, $\mu \mathrm{H}$ & 330 \\
\hline
\end{tabular}

PI valdiklio parametrai buvo parinkti taip, kad gauti minimalius inverterio išèjimo srovès netiesinius iškraipymus. Buvo naudojamos šios PI valdiklio parametrų vertès: $K_{\mathrm{P}}=10 ; K_{\mathrm{I}}=15$. Mikroinverterio išejimo srovė buvo tiriama dviem elektros tinklo ịtampos atvejams: kai tinklo ịtampos forma neiškraipyta; kai tinklo įtampos forma iškraipyta taip, kad jos spektre šalia pagrindinès harmonikos yra 3 ir 5 harmonikos. Atvejui, kai elektros tinklo įtampos forma nèra iškraipyta, mikroinverterio srovès tiekiamos ị tinklą grafikai pateikti 3.3 paveiksle. Rezultatai pateikti mikroinverterio išèjimo srovei su $200 \mathrm{~mA}$, $400 \mathrm{~mA}$ ir $600 \mathrm{~mA}$ amplitudemis, kurios atitinka $32 \mathrm{~W}, 62 \mathrm{~W}$ ir $97 \mathrm{~W}$ galią tiekiamą i tinklą. Rezultatai gauti modeliuojant programa Matlab/Simulink. Matome (3.3 pav.), kad keitiklio išèjimo srovès forma yra artima sinusui. Tačiau srovès grafikuose stebimos aukšto dažnio pulsacijos. Tyrimai parodè, kad aukšto dažnio pulsacijų amplitudė ženkliai priklauso nuo PI valdiklio proporcinio koeficiento $K_{\mathrm{P}}$ vertès. Pulsacijos mažèja, jei $K_{\mathrm{P}}$ vertè mažèja. Tačiau mažinant $K_{\mathrm{P}}$, didejja srovès formos iškraipymai, o ženkliai sumažinus $K_{\mathrm{P}}$, srovès fazè pasislenka atžvilgiu ịtampos fazès, t. y. mikroinverteris pradeda generuoti ị elektros tinklą reaktyviają galią. Visi tyrimų rezultatai gauti prie $36 \mathrm{kHz}$ IPM 
signalo, kuriuo valdomi mikroinverterio raktų tranzistoriai, raktų komutavimo dažniui.

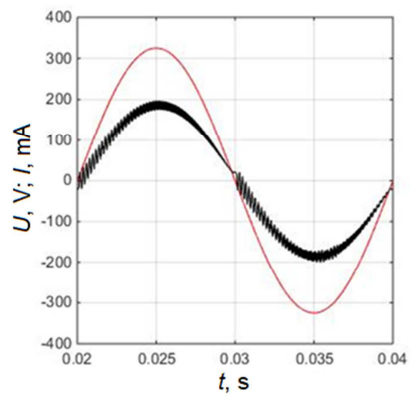

a)

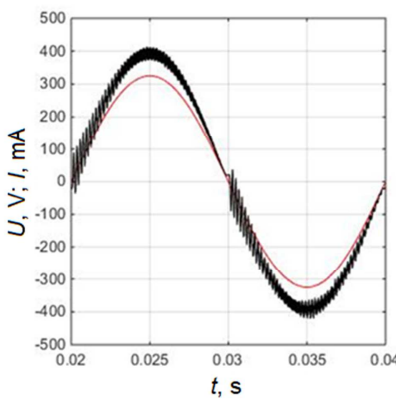

b)

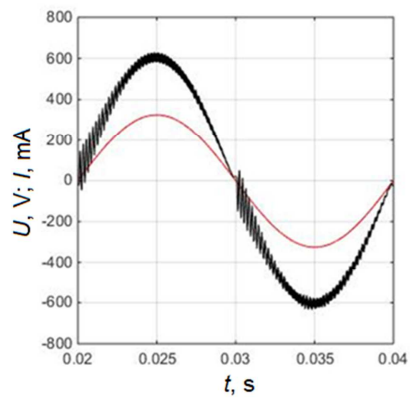

c)

3.3 pav. Mikroinverterio išèjimo srovè (juoda kreivè) naudojant proporcinį integralinị valdikli prie ịvairių apkrovos galių: a) $32 \mathrm{~W}$; b) $62 \mathrm{~W}$; c) $97 \mathrm{~W}$. Elektros tinklo įtampa raudonos kreives

Fig. 3.3. The microinverter output current (black curves) when using the proportionalintegral controller at different load power: a) $32 \mathrm{~W}$; b) $62 \mathrm{~W}$; c) $97 \mathrm{~W}$. Red curves - the electric grid voltage

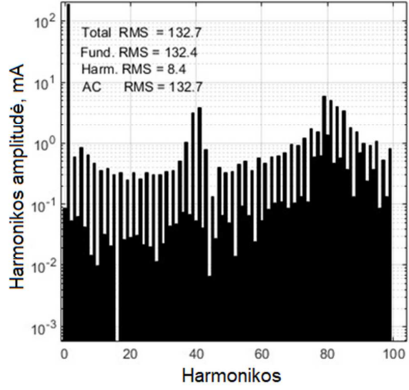

a)

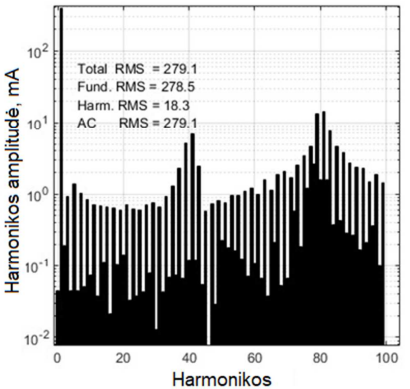

b)

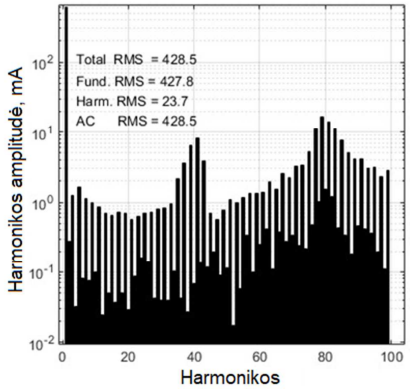

c)

3.4 pav. Mikroinverterio išèjimo srovès spektrai naudojant proporcinị integralinị valdiklị prie ịvairių apkrovos galių: a) $32 \mathrm{~W}$; b) $62 \mathrm{~W}$; c) $97 \mathrm{~W}$. Elektros tinklo ittampos forma neiškraipyta.

Fig. 3.4. Spectra of the output current of the microinverter based on the proportionalintegral controller at the load power: a) $32 \mathrm{~W}$; b) $62 \mathrm{~W}$; c) $97 \mathrm{~W}$ in the case when the electric grid voltage shape is not distorted

Mikroinverterio išèjimo srovès spektrai gauti naudojant greitają Furjè transformaciją, kai mikroinverterio tiekiama ị elektros tinklą galia yra $32 \mathrm{~W}$, $62 \mathrm{~W}$ ir $97 \mathrm{~W}$, pateikti 3.4 paveiksle. Matome, kad didžiausias amplitudes turi $37-43$ ir 79-83 harmonikos. Spektro analizė rodo, kad netiesiniai srovès 
iškraipymai sudaro $6,3 \%$ esant $32 \mathrm{~W}, 6,6 \%$ esant $62 \mathrm{~W}$ ir 5,5\% esant $97 \mathrm{~W}$ apkrovos galiai.

Paprastai elektros tinklo įtampos forma būna iškraipyta, todèl aktualu yra ištirti mikroinverterio tiekiamą i tinklą srovę esant tinklo įtampos formos iškraipymams. Mikroinverterio išejimo srovè buvo analizuojama kai elektros tinklo itampą yra iškraipyta trečiaja ir penktąja harmonikomis, t. y. harmonikomis kurių dažnis atitinkamai $150 \mathrm{~Hz}$ ir $250 \mathrm{~Hz}$. Taip iškraipytą elektros tinklo įtampą galima aprašyti išraiška:

$$
u(t)=u_{1} \sin \left(\omega_{1} t\right)+u_{3} \sin \left(\omega_{3} t\right)+u_{5} \sin \left(\omega_{5} t\right),
$$

čia $u_{1}=325 \mathrm{~V}, u_{3}=55 \mathrm{~V} ; u_{5}=55 \mathrm{~V}$ - atitinkamai pirmosios, trečiosios ir penktosios harmonikų amplitudès; $\omega_{1}=314 \mathrm{rad} / \mathrm{s}, \omega_{3}=942 \mathrm{rad} / \mathrm{s}$, $\omega_{5}=1570 \mathrm{rad} / \mathrm{s}-$ atitinkamai pirmosios, trečiosios ir penktosios harmonikų kampiniai dažniai.

Gauti srovès ir itampos modeliavimo rezultatai pateikti 3.5 paveiksle. Matome, kad esant $32 \mathrm{~W}$ mikroinverterio apkrovai, stebima srovès pusperiodžio asimetrija. Asimetrija mažeja didejant apkrovos galiai ir tampa beveik nepastebima esant $97 \mathrm{~W}$ mikroinverterio apkrovos galiai.

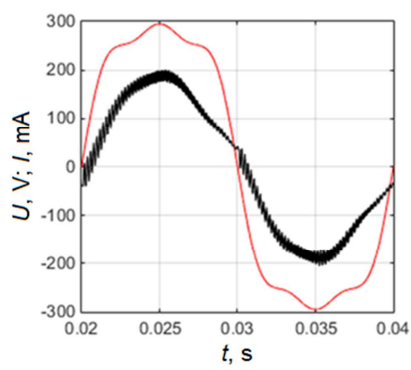

a)

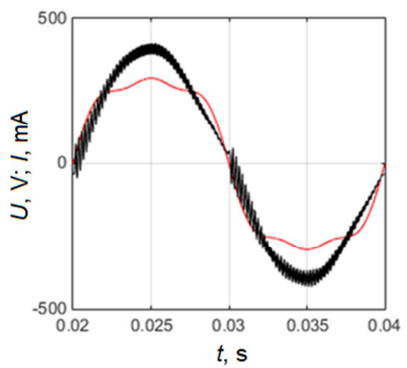

b)

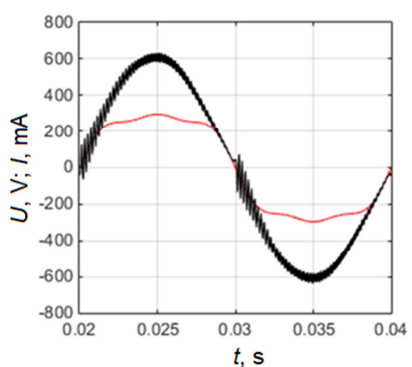

c)

3.5 pav. Mikroinverterio išèjimo srovè (juodos kreivès) naudojant proporcinį integralini valdikli prie įvairių apkrovos galių: a) $32 \mathrm{~W}$; b) $62 \mathrm{~W}$; c) $97 \mathrm{~W}$. Elektros tinklo įtampos forma (raudonos kreivess) iškraipyta 3 ir 5 harmonikomis

Fig. 3.5. The microinverter output current (black curves) when using the proportionalintegral controller at a different load power: a) $32 \mathrm{~W}$; b) $62 \mathrm{~W}$; c) $97 \mathrm{~W}$. The electric grid voltage (red curves) is distorted by $3 \mathrm{rd}$ and 5 th harmonics

Mikroinverterio išèjimo srovès spektrai esant $32 \mathrm{~W}, 62 \mathrm{~W}$ ir $97 \mathrm{~W}$ apkrovos galiai pateikti 3.6 paveiksle. Naudojant gautus spektrus apskaičiuoti srovès netiesiniai iškraipymai sudaro $9,9 \%$ esant $32 \mathrm{~W}, 8,9 \%$ esant $62 \mathrm{~W}$ ir $6,1 \%$ esant $97 \mathrm{~W}$ apkrovos galiai, t. y. iškraipymai yra didesni, lyginant atitinkamai su vertemis $(6,3 \%, 6,6 \%, 5,5 \%)$, kurios buvo gautos tuo atveju, kai elektros tinklo itampos forma nebuvo iškraipyta. Todèl galima daryti išvadą, kad elektros tinklo 
ịtampos formos iškraipymai 3-ja ir 5-ja harmonikomis padidina išejimo srovès iškraipymą ir šis prieaugis yra didesnis esant mažesnei apkrovai.

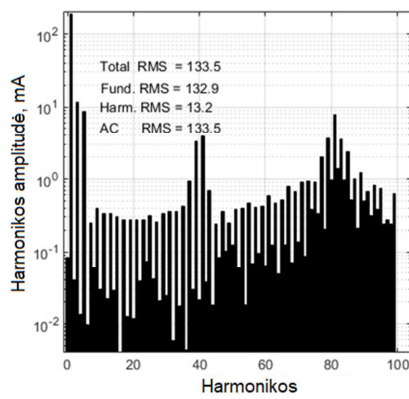

a)

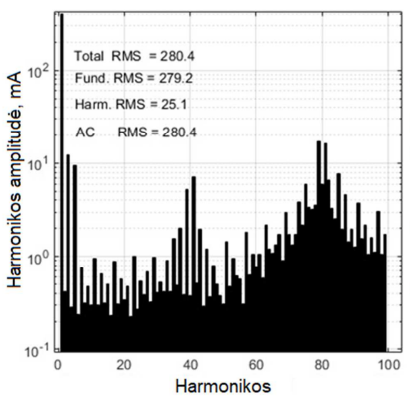

b)

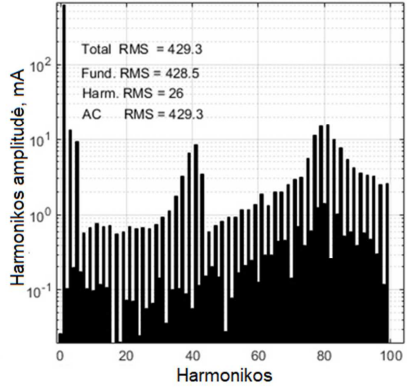

c)

3.6 pav. Mikroinverterio išèjimo srovès spektrai naudojant proporcinị integralinị valdiklị prie įvairiu apkrovos galių: a) $32 \mathrm{~W}$; b) $62 \mathrm{~W}$; c) $97 \mathrm{~W}$. Elektros tinklo įtampos forma iškraipyta 3 ir 5 harmonikomis

Fig. 3.6. Spectra of the output current of the microinverter based on the proportionalintegral controller at the load power: a) $32 \mathrm{~W}$; b) $62 \mathrm{~W}$; c) $97 \mathrm{~W}$. The electric grid voltage is distorted by $3 \mathrm{rd}$ and 5 th harmonics

\subsubsection{Proporcinis integralinis valdiklis su keičiamu laike proporciniu koeficientu}

Modeliavimo rezultatai (3.3 ir 3.5 pav.) rodo, kad mikroinverterio išèjimo srovè turi aukšto dažnio pulsacijas. Tyrimai parodè, kad pulsacijų amplitudè priklauso nuo PI valdiklio proporcinio nario agresyvumo, t. y., nuo proporcinio koeficiento $K_{\mathrm{P}}$ vertès. Mažinant $K_{\mathrm{P}}$, pulsacijų amplitudè mažèja. Tačiau jei $K_{\mathrm{P}}$ yra per mažas, mikroinverterio išějimo srovès amplitudè nepasiekia nustatytosios vertès ir atsiranda formos iškraipymas. İvertinus gautus tyrimų rezultatus, galima daryti prielaidą, kad norint sumažinti mikroinverterio išèjimo srovès aukšto dažnio pulsacijas ir tuo pat metu sinuso formos iškraipymą žemo dažnio harmonikomis, būtina, kad esant mažai srovès vertei, artimai nuliui, $K_{\mathrm{P}}$ būtų sumažintas, o esant didelei srovès vertei, artimai amplitudès vertei, $K_{\mathrm{P}}$ turi turèti tam tikrą maksimalią vertę.

Remiantis aukščiau padaryta išvada, galima daryti prielaidą, kad $K_{\mathrm{P}}$ turètų kisti proporcingai mikroinverterio išèjimo srovei, kad būtu sumažintos išèjimo srovès aukšto dažnio pulsacijos ir tuo pat metu jos forma nebūtų iškraipyta žemo dažnio harmonikomis. Siūlomo PI valdiklio su keičiamu laike proporciniu koeficientu $K_{\mathrm{P}}=K_{\mathrm{V}}(t) K_{\mathrm{C}}$ valdymo algoritmas yra toks: 


$$
U(t)=K_{\mathrm{V}}(t) K_{\mathrm{C}} e(t)+K_{\mathrm{I}} \int_{t_{0}}^{t} e(t) \mathrm{d} t,
$$

čia $K_{\mathrm{V}}(t)$ ir $K_{\mathrm{C}}$ - atitinkamai, kintantis laike ir pastovusis proporcinio koeficiento nariai. Mikroinverterio valdymo sistemos modeliavimo rezultatai rodo, kad maži mikroinverterio išèjimo srovès formos iškraipymai pasiekiami, kai $K_{\mathrm{V}}(t)$ kiekvieną srovės pusperiodị kinta panašiu dèsniu kaip ir srovė. Buvo nustatyta, kad tokie patys rezultatai gaunami, jei vietoje sinuso dèsnio $K_{\mathrm{V}}(t)$ priklausomybei nuo laiko aprašyti naudojama jos gabalais tiesine aproksimacija, pateikta 3.7 paveiksle. Išraiška (3.5) aprašo priklausomybę, pateiktą 3.7 paveiksle. Išraiškos (3.5), aprašančios $K_{\mathrm{V}}(t)$, parametrai buvo nustatyti iteraciniu būdu, siekiant minimalios srovès netiesinių iškraipymų vertės.

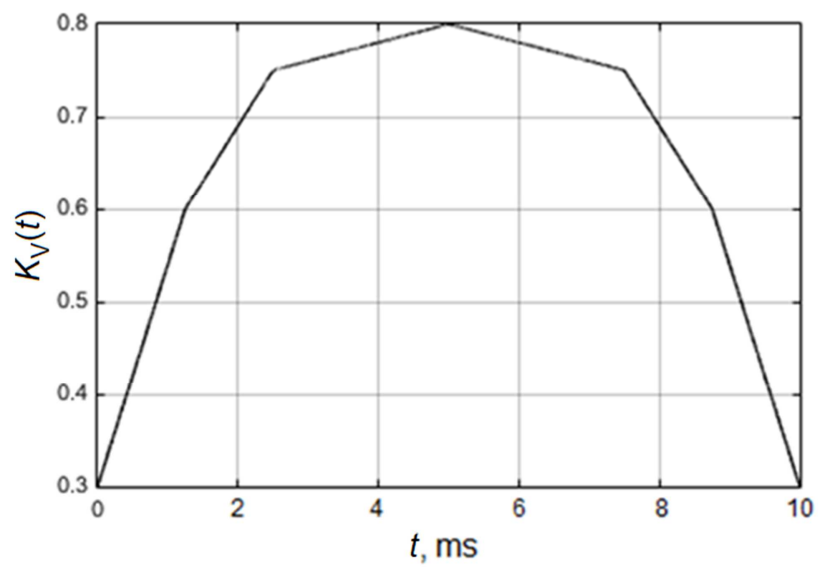

3.7 pav. Nario $K_{\mathrm{V}}(t)$ kitimas laike

Fig. 3.7. Variation of time-varying constant $K_{\mathrm{V}}(t)$ with time

$$
K_{\mathrm{V}}(t)=\left\{\begin{array}{lll}
0,3+0.24 t, & \text { kai } 0 \leq t \leq 1,25 \\
0,6+0,12(t-1,25), & \text { kai } 1,25 \leq t \leq 2,5 \\
0,75+0,02(t-2,5), & \text { kai } 2,5 \leq t \leq 5 \\
0,8-0,02(t-5), & \text { kai } 5 \leq t \leq 7,5 \\
0,75+0,12(t-7,5), & \text { kai } 7,5 \leq t \leq 8,75 \\
0,6-0,24(t-8,75), & \text { kai } 8,75 \leq t \leq 10 .
\end{array}\right.
$$

Mikroinverterio valdymo sistemos su PI valdikliu keičiamu laike proporciniu koeficientu, struktūrinè schema pateikta 3.8 paveiksle. 


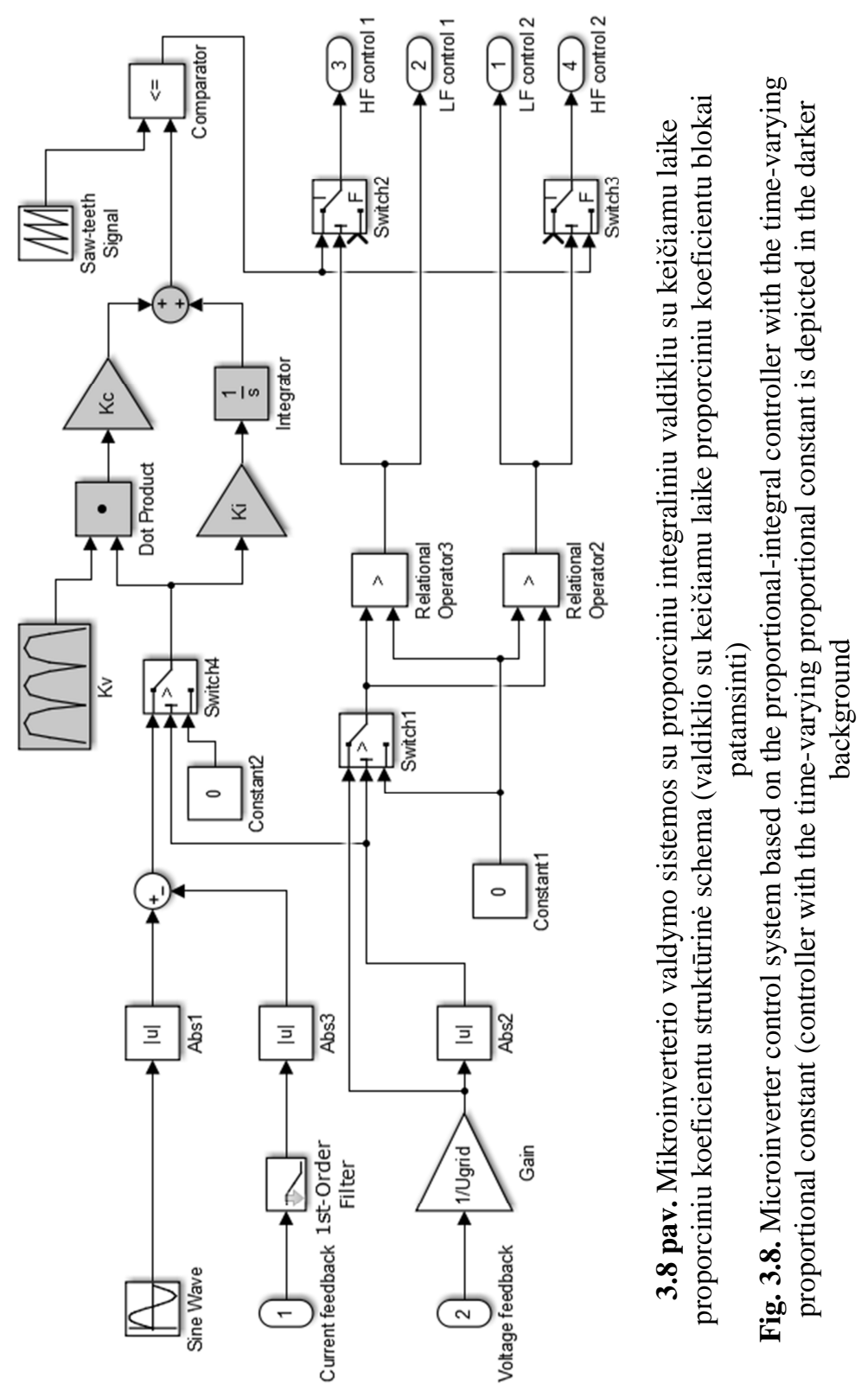




\subsubsection{Mikroinverterio srovès valdymo sistemos su proporciniu integraliniu valdikliu su keičiamu laike proporciniu koeficientu tyrimas}

Mikroinverterio valdymo sistema su siūlomu PI valdikliu su keičiamu laike proporciniu koeficientu buvo tiriama esant $32 \mathrm{~W}, 62 \mathrm{~W}$ ir $97 \mathrm{~W}$ galiai tiekiamai mikroinverterio i elektros tinklą. Šios galios vertès atitinka $200 \mathrm{~mA}, 400 \mathrm{~mA}$ ir 600 mA mikroinverterio išèjimo srovès amplitudę.

Analizuojama mikroinverterio srovès valdymo sistema yra netiesinè, o valdiklio parametrus būtina priderinti siekiant minimalių keitiklio išẻjimo srovès netiesinių iškraipymų. Žinomi klasikiniai PI valdiklio derinimo metodai šiuo atveju netinka. PI valdiklio parametrus tokioje situacijoje galima suderinti naudojant optimizavimo metodus (Singh et al. 2017). Valdiklio parametrams nustatyti buvo naudojamas vienmatis (angl. univariate) ekstremumo paieškos metodas (Al-Saleh ey al. 1999; Wilson et al. 2013). Šis metodas sukurtas netiesinėms sistemoms optimizuoti ir yra santykinai paprastas. Kiekvienos iteracijos metu keičiama tik vieno kintamojo vertė ieškant jo optimalios vertès, prie fiksuotų kitų kintamụjų verčių. Kai visi kintamieji yra pakeisti, procedūra vèl kartojama tol, kol gaunama minimali (maksimali) tikslo funkcijos reikšmè.

Siūlomo PI valdiklio derinimo tikslas - surasti valdiklio parametrų $K_{\mathrm{C}}$ ir $K_{\mathrm{I}}$ vertes, prie kurių mikroinverterio išèjimo srovès netiesiniai iškraipymai yra minimalūs, t. y. sprendžiamas optimizavimo uždavinys su dviem kintamaisiais. Taikant vienmati paieškos metodą, valdiklio parametrų vertès yra nustatomos taip: fiksuotai pradinei $K_{\mathrm{C}}=K_{\mathrm{Ci}}$ reikšmei, keičiant $K_{\mathrm{I}}$ buvo rasta $K_{\mathrm{I}}=K_{\mathrm{Io} 1}$ vertè, prie kurios srovès netiesiniai iškraipymai yra mažiausi; fiksuotai $K_{\mathrm{I}}=K_{\mathrm{Io} 1}$ reikšmei, keičiant $K_{\mathrm{C}}$ buvo rasta $K_{\mathrm{C}}=K_{\mathrm{Co1}}$ vertè, kuriai esant netiesiniai iškraipymai yra mažiausi. Šis procesas yra kartojamas tol, kol gaunama minimali netiesinių iškraipymų vertè. Optimizavimo procedūra buvo pakartota su skirtingomis pradinėmis $K_{\mathrm{C}}=K_{\mathrm{Ci}}$ reikšmėmis. Gautos optimalios PI valdiklio su keičiamu laike proporciniu koeficientu parametru vertės yra šios: $K_{\mathrm{C}}=10$, $K_{\mathrm{I}}=15$.

Mikroinverterio, kuriame išèjimo srovès valdymui panaudotas PI valdiklis su keičiamu laike proporciniu koeficientu, srovè ir elektros tinklo itampa atvaizduoti 3.9 paveiksle. Tyrimai atlikti atvejui kai elektros tinklo ịtampa yra neiškraipyta. Gauti rezultatai rodo, kad naudojant siūlomą PI valdikli galima sumažinti išèjimo srovès aukšto dažnio pulsacijas, lyginant su atveju, kai naudojamas iprastas PI valdiklis (palyginkite srovès kreives, pateiktas 3.9 paveiksle su pateiktomis 3.3 paveiksle). Mikroinverterio išèjimo srovès spektrai esant $32 \mathrm{~W}, 62 \mathrm{~W}$ ir $97 \mathrm{~W}$ galiai tiekiamai ì tinklą yra pateikti 3.10 paveiksle. Naudojant spektruose pateiktus duomenis, apskaičiuoti netiesiniai 
srovès iškraipymai sudaro $4,4 \%$ esant $32 \mathrm{~W}, 3,4 \%$ esant $62 \mathrm{~W}$ ir $3,3 \%$ esant $97 \mathrm{~W}$ galiai. Gautų netiesinių iškraipymų verčių palyginimas su gautomis tuo atveju, kai naudojamas ịprastas PI valdiklis, rodo, kad siūlomo PI valdiklio su keičiamu laike proporciniu koeficientu naudojimas leidžia sumažinti mikroinverterio išèjimo srovès netiesinius iškraipymus $30 \%$ esant $32 \mathrm{~W}, 48 \%$ esant $62 \mathrm{~W}$ ir $40 \%$ esant $97 \mathrm{~W}$ galiai tiekiamai ị elektros tinklą.

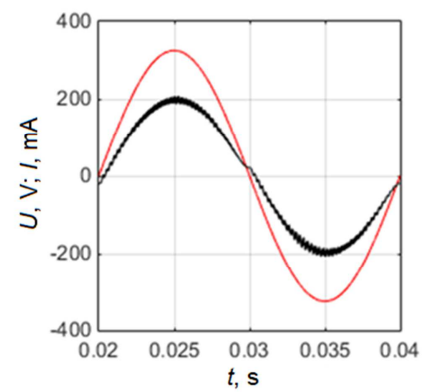

a)

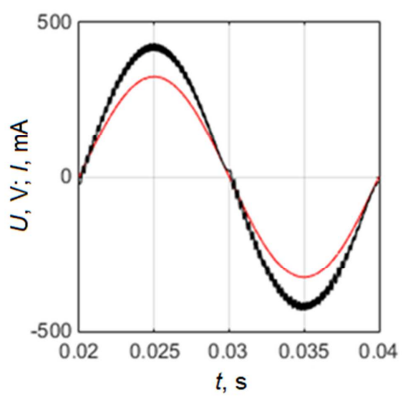

b)

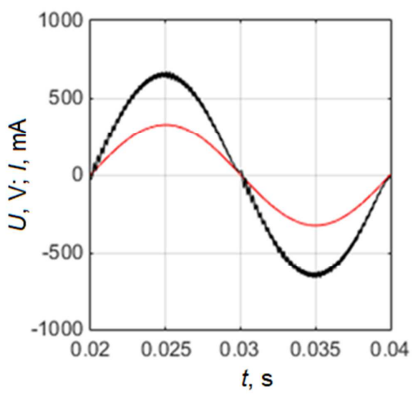

c)

3.9 pav. Mikroinverterio išèjimo srovè (juoda kreivè), naudojant proporcinị integralinị valdiklị su keičiamu laike proporciniu koeficientu, prie įvairių apkrovos galių: a) $32 \mathrm{~W}$;

b) $62 \mathrm{~W}$; c) $97 \mathrm{~W}$. Elektros tinklo įtampa - raudonos kreivès

Fig. 3.9. The microinverter output current (black curves) when using the proportionalintegral controller with time-varying proportional constant at different load power:

a) $32 \mathrm{~W}$, b) $62 \mathrm{~W}$; c) $97 \mathrm{~W}$. Red curves - the electric grid voltage

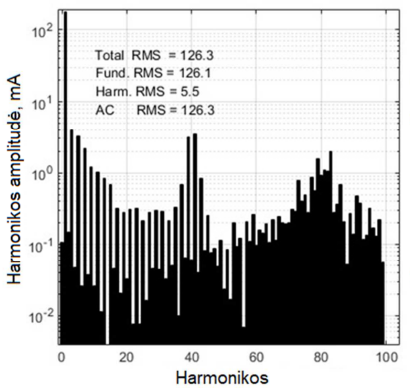

a)

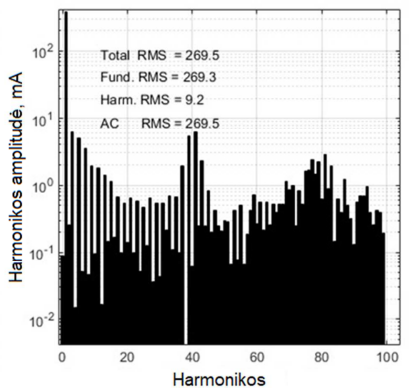

b)

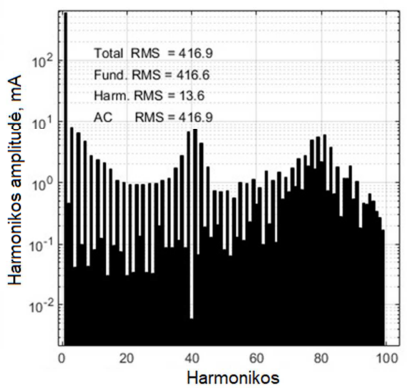

c)

3.10 pav. Mikroinverterio išejimo srovės spektrai, naudojant proporcinį integralini valdiklį su keičiamu laike proporciniu koeficientu, prie įvairių apkrovos galių: a) $32 \mathrm{~W}$;

b) $62 \mathrm{~W}$; c) $97 \mathrm{~W}$, kai elektros tinklo įtampos forma neiškraipyta

Fig. 3.10. Spectra of the output current of the microinverter based on the proportionalintegral controller with time-varying proportional constant at the load power: a) $32 \mathrm{~W}$;

b) $62 \mathrm{~W}$; c) $97 \mathrm{~W}$ in the case when the electric grid voltage shape is not distorted

Inverterio išèjimo srovè naudojant siūlomą PI valdiklị su keičiamu laike proporciniu koeficientu taip pat buvo tiriama atveju, kai elektros tinklo ịtampa 
yra iškraipyta 3-ja ir 5-aja harmonikomis ir yra aprašoma (3.3) išraiška. Mikroinverterio išèjimo srovès ir elektros tinklo įtampos kreivès pateiktos 3.11 paveiksle, harmonikų spektras. Palyginus gautas kreives su pateiktomis 3.5 paveiksle, matosi, kad PI valdiklis su keičiamu laike proporciniu koeficientu leidžia sumažinti srovès aukšto dažnio pulsacijų amplitudę, lyginant su atveju kai srovès valdymo sistema yra realizuota naudojant ịprastinị PI valdiklį.

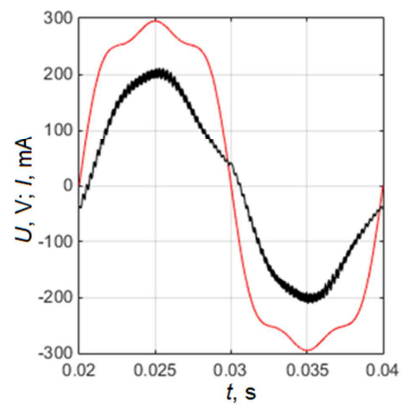

a)

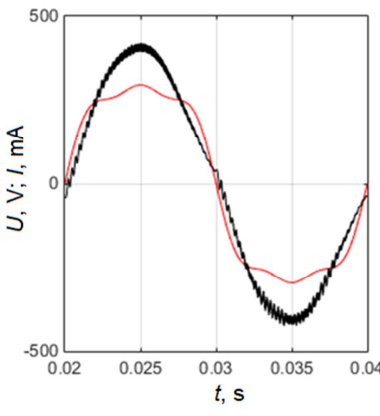

b)

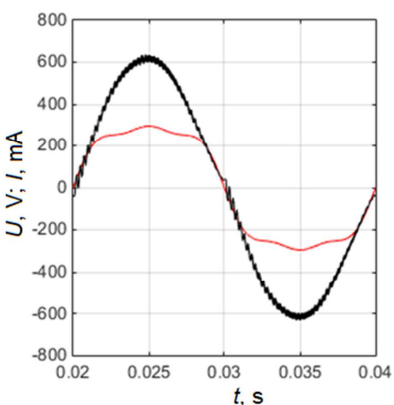

c)

3.11 pav. Mikroinverterio išèjimo srovė (juodos kreivės), naudojant proporcinị integralinị valdikli su keičiamu laike proporciniu koeficientu, prie ịvairiu apkrovos galių: a) $32 \mathrm{~W}$; b) $62 \mathrm{~W}$; c) $97 \mathrm{~W}$. Elektros tinklo įtampos forma (raudonos kreivès) iškraipyta 3 ir 5 harmonikomis

Fig. 3.11. The microinverter output current (black curves) when using the proportionalintegral controller with time-varying proportional constant at different load power:

a) $32 \mathrm{~W}$, b) $62 \mathrm{~W}$; c) $97 \mathrm{~W}$. The electric grid voltage (red curves) is distorted by the 3rd and 5th harmonics

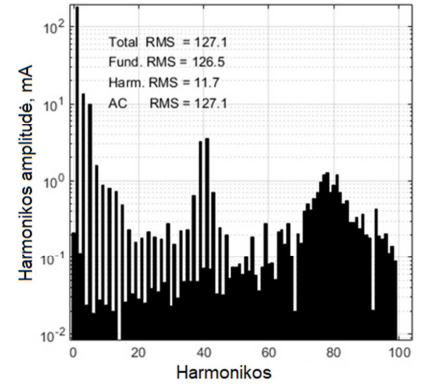

a)

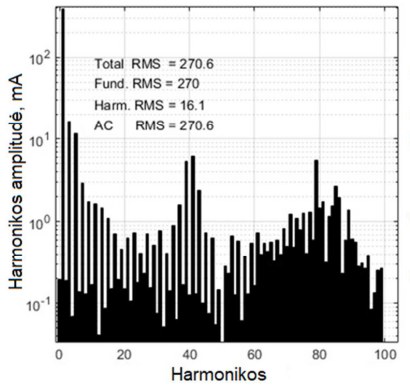

b)

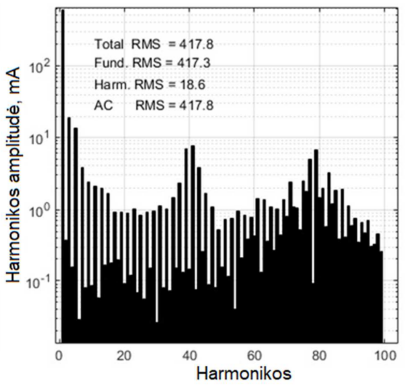

c)

3.12 pav. Mikroinverterio išèjimo srovès spektrai, naudojant proporcinị integralinị valdiklį su keičiamu laike proporciniu koeficientu, prie ịvairių apkrovos galių: a) $32 \mathrm{~W}$;

b) $62 \mathrm{~W}$; c) $97 \mathrm{~W}$. Elektros tinklo ịtampos forma iškraipyta 3 ir 5 harmonikomis Fig. 3.12. Spectra of the output current of the microinverter based on the proportionalintegral controller with time-varying proportional constant at the load power: a) $32 \mathrm{~W}$; b) $62 \mathrm{~W}$; c) $97 \mathrm{~W}$ for the electric grid voltage distorted by the 3rd and 5th harmonics 
Mikroinverterio išèjimo srovès spektrai pateikti 3.12 pav. Remiantis spektru duomenimis apskaičiuoti srovès netiesiniai iškraipymai sudaro $9,2 \%$ esant 32 $\mathrm{W}, 6,0 \%$ esant $62 \mathrm{~W}$ ir 4,5\% esant $97 \mathrm{~W}$ apkrovos galiai. Palyginus gautas netiesinių iškraipymų reikšmes su gautomis tuo atveju, kai naudojamas ịprastas PI valdiklis, matome, kad siūlomas PI valdiklis su keičiamu laike proporciniu koeficientu leidžia sumažinti mikroinverterio išèjimo srovès netiesinius iškraipymus $7 \%$ esant $32 \mathrm{~W}, 33 \%$ esant $62 \mathrm{~W}$ ir $26 \%$ esant $97 \mathrm{~W}$ apkrovos galiai.

Atliktas eksperimentinis mikroinverterio, kuriame išèjimo srovės valdymui naudojamas PI valdiklis su keičiamu laike proporciniu koeficientu, tyrimas. Mikroinverterio galios pakopos elektrinè schema pateikta 3.1 paveiksle. Galios pakopos elementų tipai ir parametrai pateikti 3.2 lentelèje.

3.2 lentelè. Mikroinverterio galios dalies elementų tipai ir parametrai

Table 3.2. Types and parameters of microinveter power stage components

\begin{tabular}{|l|l|l|}
\hline Komponentas & Tipas & Maksimali leistina įtampa ir srovė \\
\hline Q1, Q2, Q3, Q4 & IRF3205 & 55V; 110 A \\
\hline Q5, Q6 & 2SK2717 & 900 V; 5 A \\
\hline D1, D2 & FUF5408 & $1000 \mathrm{~V} ; 3 \mathrm{~A}$ \\
\hline
\end{tabular}

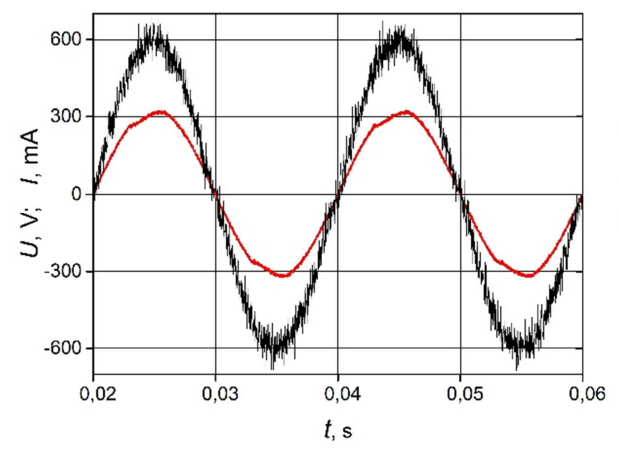

a)

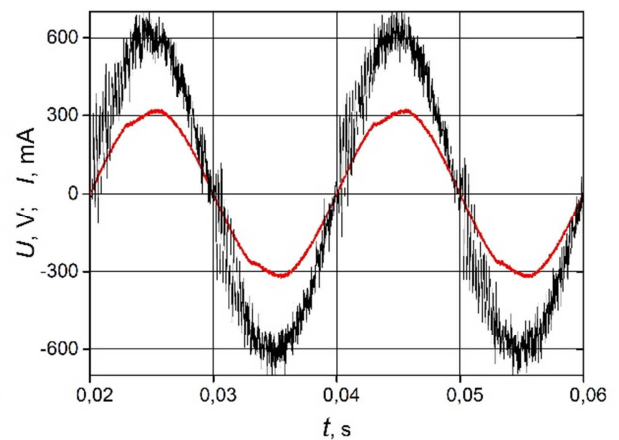

b)

3.13 pav. Mikroinverterio išèjimo srovè (juodos kreivès), naudojant proporcini integralinị valdiklị su keičiamu laike proporciniu koeficientu (a) ir ịprastinị proporcini integralini valdikli (b). Elektros tinklo įtampa - raudonos kreivès

Fig.3.13. The microinverter output current (black curves) when using the ordinary proportional-integral controller (a) and the proportional-integral controller with timevarying proportional constant (b). Red curves - the electric grid voltage 
Grįžtamojo transformatoriaus ir CL filtro parametrai pateikti 3.1 lentelèje. Valdymo sistema buvo realizuota naudojant mikrovaldiklį dsPIC33FJ16GS504. Gautos eksperimentinès srovès ir tinklo itampos kreivès pateiktos 3.13 paveiksle. Ten pat, palyginimui pateiktos ir eksperimentinès kreivès gautos naudojant iprastini PI valdiklị. Tyrimas atliktas esant $600 \mathrm{~mA}$ išejimo srovès amplitudei, prie kurios galia tiekiama ị tinklą sudaro $100 \mathrm{~W}$. Matoma, kad valdymo sistema, pagrịsta siūlomu valdikliu kuria mažesnius srovès iškraipymus palyginti su tuo atveju, kai naudojamas ịprastas PI valdiklis. Aukšto dažnio trikdžiai, atsirandantys eksperimentiškai gautose mikroinverterio išejimo srovès kreivèse, kurių nèra kreivèse gautuose modeliuojant, yra matavimų grandinę veikiantys elektromagnetiniai trikdžiai, kuriuos generuoja mikroinverterio galios laipsnis. Tiriamojo elektros tinklo ịtampos formą (raudonos kreivès 3.13 paveiksle) yra nežymiai iškraipyta netiesinių tinklo apkrovų.

\subsection{Elementụ parametru ịtakos mikroinverterio energetiniam efektyvumui tyrimas}

Pagrindinius vienos pakopos mikroinverterio, sudaryto iš dviejų raktų grižtamụjų keitiklių, energijos nuostolius sąlygoja nuostoliai raktų tranzistoriuose ir grịžtamajame transformatoriuje. Todèl mikroinverterio naudingumo koeficientas, nežiūrint naujų sprendimų, leidžiančių ji didinti, gali išlikti santykinai žemas jei jame naudojami raktų tranzistoriai ir grižtamasis transformatorius bus parinkti su netinkamais parametrais (Jang et al. 2012; Prager et al. 2015). Dèl šios priežasties svarbu ištirti minètų komponentų parametrų itaką mikroinverterio galios nuostoliams. Itaką mikroinverterio naudingumo koeficientui daro ir galios nuostoliai išejimo filtre, todèl aktualu mikroinverterio naudingumo koeficiento tyrimus atlikti naudojant skirtingus išèjimo filtrus (Bao et al. 2014; Azani et al. 2014; Macedo et al. 2016).

Tyrimai atlikti modeliuojant Matlab/Simulink programa. Mikroinverteris buvo tiriamas veikiant jam su dviem skirtingais išējimo filtrais: CL ir LCL (3.14 pav.).

Ištirta mikroinverteryje naudojamų MOSFET raktų tranzistorių varžos, kai raktas atviras $\left(R_{\text {on }}\right)$, grịztamojo transformatoriaus pirminès $\left(r_{1}\right)$ ir antrinès $\left(r_{2}\right)$ apvijų aktyvinių varžų ịtaka mikroinverterio naudingumo koeficientui. Tyrimas atliktas $25 \mathrm{kHz}$ IPM raktų komutavimo dažniui, atvejams, kai mikroinverteryje yra naudojami CL ir LCL išejimo filtrai, pagal žemiau pateiktą planą:

1. Raktų tranzistorių Q1-Q4 parametro $R_{\text {on }}$ ittakos mikroinverterio naudingumo koeficientui tyrimas. 
2. Raktų tranzistorių Q5, Q6 parametro $R_{\text {on }}$ itakos mikroinverterio naudingumo koeficientui tyrimas.

3. Grį̌ztamojo transformatoriaus pirminès apvijos aktyvinès varžos ịtakos mikroinverterio naudingumo koeficientui tyrimas.

4. Grịžtamojo transformatoriaus antrinès apvijos aktyvinès varžos ịtakos mikroinverterio naudingumo koeficientui tyrimas.

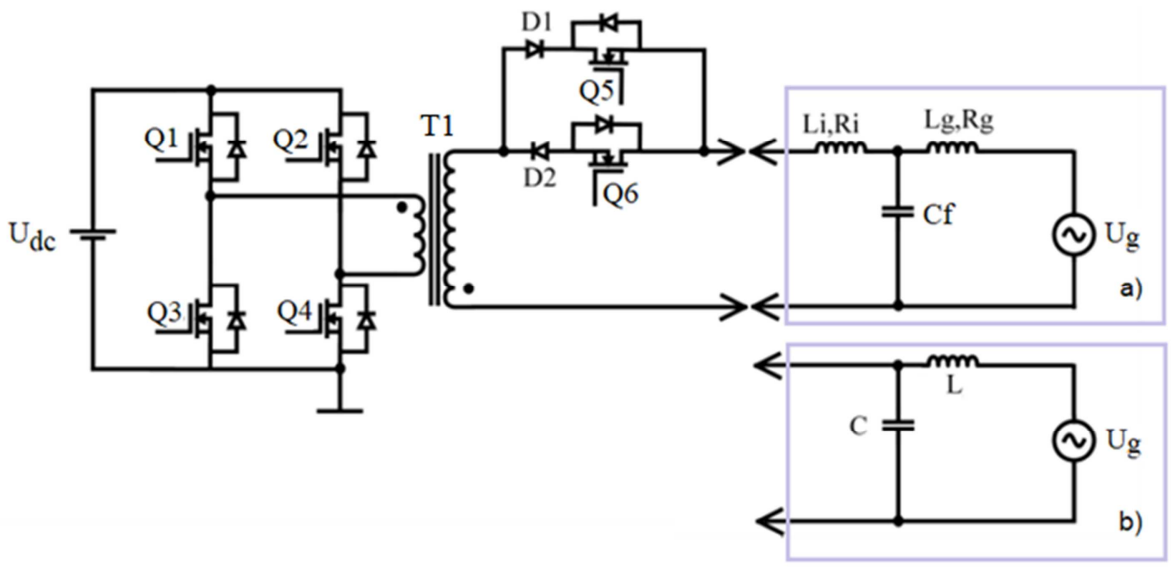

3.14 pav. Mikroinverterio galios dalies elektrinè schema:a) su CL filtru; b) su LCL filtru Fig. 3.14. Circuit diagram of microinverter power stage: a) with CL filtre; b) with LCL filter

Tiriamojo mikroinverterio parametrai pateikti 3.3 lentelëje. Mikroinverterio naudingumo koeficiento priklausomybès nuo generuojamos ị elektros tinklą galios ịvairioms raktų Q1-Q4 parametro $R_{\text {on }}$ vertèms, kai naudojamas CL išèjimo filtras, pateiktos 3.15 paveiksle. Matome, kad maksimali naudingumo koeficiento vertė 0,984 gaunama prie $R_{\text {on }}=0,04 \Omega$, esant $50 \mathrm{~W}$ tiekiamai ì elektros tinklą galiai. Naudingumo koeficientas mažèja augant galiai, tačiau išlieka aukštas visame tirtų galų diapazone ir prie $148 \mathrm{~W}$ siekia 0,956 . Didejjant atvirojo tranzistoriaus varžai $R_{\text {on }}$ nuo 0,04 iki $0,12 \Omega$, naudingumo koeficientas mažèja maždaug $7 \%$. 


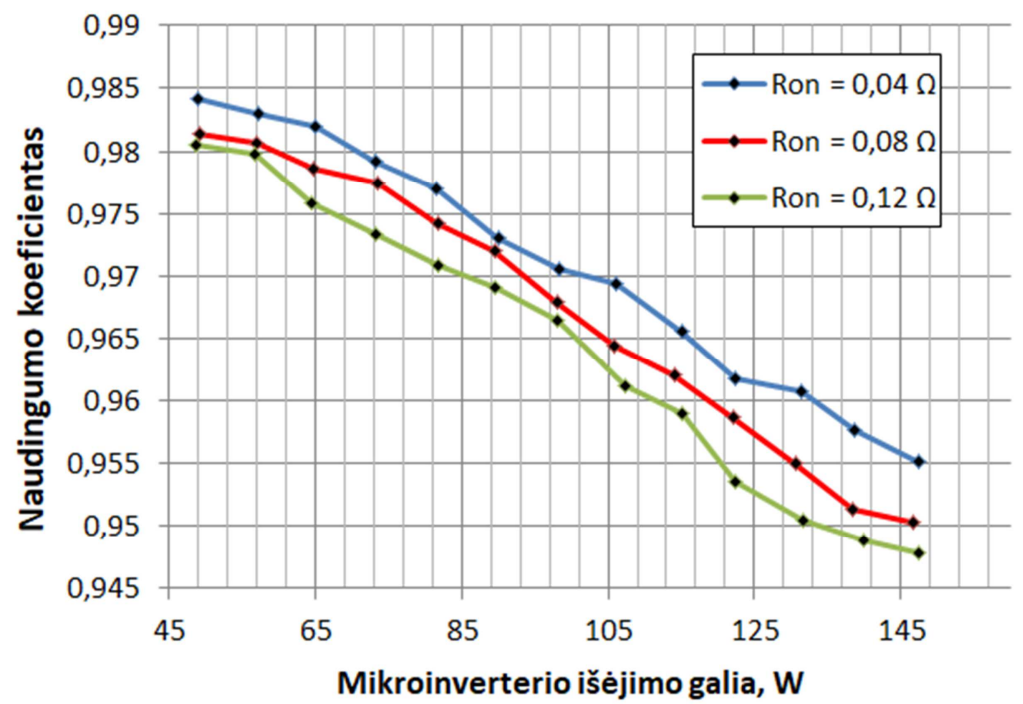

3.15 pav. Mikroinverterio su CL filtru naudingumo koeficiento priklausomybè nuo galios, įvairioms raktų Q1-Q4 parametro $R_{\text {on }}$ vertèms

Fig. 3.15. Efficiency dependences on the output power of microinverter with the CL low pass output filter for various values of switches Q1-Q4 parameter $R_{\text {on }}$

3.3 lentelė Pagrindiniai mikroinverterio komponentų parametrai Talbe 3.3. Main parameters of microinverter components

\begin{tabular}{|l|l|l|}
\hline Parametras & Aprašymas & Verte் \\
\hline$U_{\mathrm{dc}}$ & Fotovoltinio elemento nuolatine įtampa, V & 50 \\
\hline$U_{\mathrm{g}}$ & Mikroinverterio išèjimo įtampos amplitudè, $\mathrm{V}$ & 325 \\
\hline$f$ & Mikroinverterio išèjimo kintamosios įtampos dažnis, $\mathrm{Hz}$ & 50 \\
\hline$f_{\mathrm{sw}}$ & Mikroinverterio raktų Q1-Q4 komutacijos dažnis, $\mathrm{kHz}$ & 25 \\
\hline$L_{\mathrm{i}}$ & LCL filtro induktyvumas (mikroinverterio pusėje), $\mathrm{mH}$ & 4,5 \\
\hline$L_{\mathrm{g}}$ & LCL filtro induktyvumas (elektros tinklo pusèje), $\mathrm{mH}$ & 12 \\
\hline$C_{\mathrm{f}}$ & LCL filtro kondensatorius, $\mathrm{nF}$ & 100 \\
\hline$L$ & CL filtro induktyvumas, $\mathrm{mH}$ & 5 \\
\hline$C$ & CL filtro kondensatorius, $\mathrm{nF}$ & 200 \\
\hline
\end{tabular}




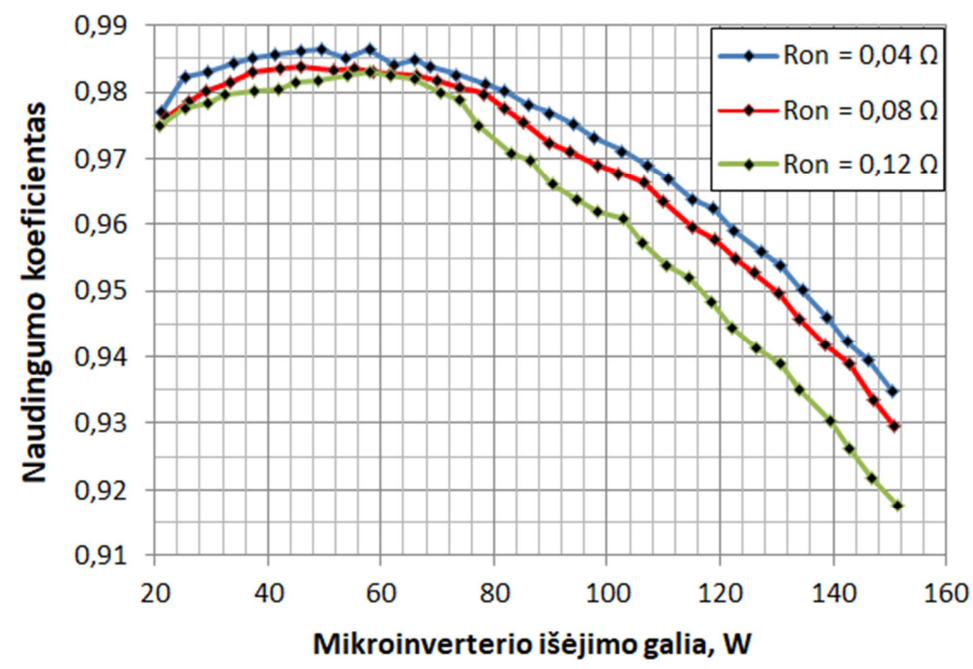

3.16 pav. Mikroinverterio su LCL filtru naudingumo koeficiento priklausomybė nuo galios, ịvairioms raktų Q1-Q4 parametro $R_{\text {on }}$ vertėms

Fig. 3.16. Efficiency dependences on the output power of microinverter with the LCL low pass output filter for various values of switches Q1-Q4 parameter $R_{\text {on }}$

Mikroinverterio naudingumo koeficiento priklausomybès nuo generuojamos i elektros tinklą galios ịvairioms raktų Q1-Q4 parametro $R_{\text {on }}$ vertėms, kai naudojamas LCL išèjimo filtras, pateiktos 3.16 paveiksle. Maksimalus naudingumo koeficientas gautas kai $R_{\mathrm{on}}=0,04 \Omega$ ir siekè 0,987 prie $50 \mathrm{~W}$ galios. Naudingumo koeficientas praktiškai nemažèja, jei išèjimo galia neviršija $80 \mathrm{~W}$. Matome, kad mikroinverteryje su LCL filtru naudingumo koeficientas prie maksimalių tirtų galių sumažèja labiau nei mikroinverteryje su CL filtru, pavyzdžiui prie $150 \mathrm{~W}$ galios, atitinkamai, iki 0,93 ir 0,95 kai $R_{\text {on }}=0,08 \Omega$ (3.15 ir 3.16 pav.).

Mikroinverterio naudingumo koeficiento priklausomybès nuo generuojamos i elektros tinklą galios įvairioms raktų Q5, Q6 parametro $R_{\text {on }}$ vertėms, kai naudojamas CL išèjimo filtras, pateiktos 3.17 paveiksle. Maksimalus naudingumo koeficientas gautas, kai išèjimo galia $50 \mathrm{~W}$ ir siekia 0,98 , esant $R_{\text {on }}=0,04 \Omega$. Didejant atvirojo tranzistoriaus varžai $R_{\text {on }}$ nuo $0,04 \Omega$ iki $0,12 \Omega$, naudingumo koeficientas mažèja apie $0,03 \%$. Parametro $R_{\text {on }}$ didinimo raktų tranzistoriuse Q5, Q6 ịtaka naudingumo koeficientui, lyginant kokią ịtaką daro šio parametro didinimas tranzistoriuse Q1-Q4 (7 \%), yra maža. Tai paaiškinama tuo, kad Q5 ir Q6 atvirų tranzistorių srovès yra žymiai mažesnès, nei tekančios per Q1-Q4 tranzistorius. 


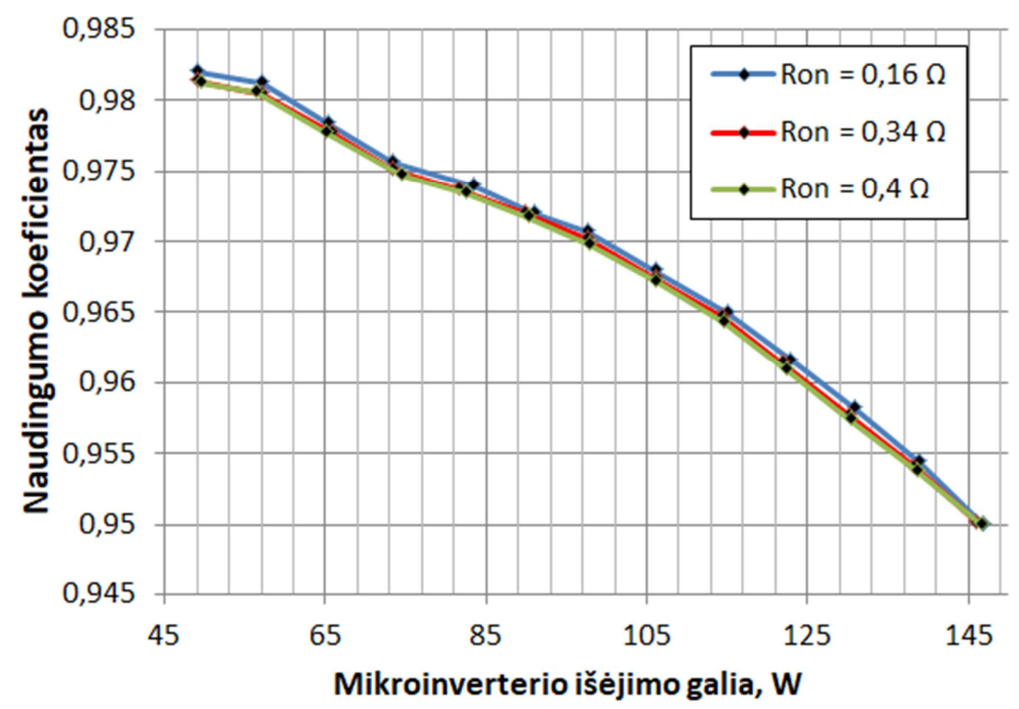

3.17 pav. Mikroinverterio su CL filtru naudingumo koeficiento priklausomybé nuo galios ịvairioms raktų Q5, Q6 parametro $R_{\text {on }}$ vertèms

Fig. 3.17. Efficiency dependences on the output power of microinverter with the CL low pass output filter for various values of switches Q5, Q6 parameter Ron

Mikroinverterio naudingumo koeficiento priklausomybès nuo generuojamos i elektros tinklą galios ịvairioms raktų Q5, Q6 parametro $R_{\text {on }}$ vertėms, kai naudojamas LCL išèjimo filtras, pateiktos 3.18 paveiksle Maksimalus naudingumo koeficientas gautas, kai mikroinverterio išèjimo galia $57 \mathrm{~W}$ siekia 0,98 , kai $R_{\text {on }}=0,04$. Matome, kad mikroinverteryje su LCL filtru naudingumo koeficientas prie maksimalių tirtų galių sumažeja labiau nei mikroinverteryje su CL filtru, pavyzdžiui, prie $150 \mathrm{~W}$ galios, naudingumo koeficientai, atitinkamai sudaro 0,933 ir 0,95 (3.15 ir 3.16 pav.).

Buvo tiriama grižtamojo transformatoriaus apvijų aktyvinès varžos ịtaka mikroinverterio naudingumo koeficientui. Mikroinverterio naudingumo koeficiento priklausomybės nuo generuojamos į elektros tinklą galios ịvairioms grịžtamojo transformatoriaus pirminès apvijos aktyvinès varžos $r_{1}$ vertėms, kai naudojamas CL išejimo filtras, pateiktos 3.19 paveiksle. Iš gautų rezultatų matyti, kad pirminès apvijos aktyvinès varžos mažinimas nuo 0,24 iki $0,06 \Omega$ leidžia padidinti efektyvumą nuo 0,93 iki 0,97 , t. y. apie $4 \%$ prie $100 \mathrm{~W}$ galios. Mikroinverteriui veikiant su LCL žemo dažnio filtru naudingumo koeficientas išauga nuo 0,90 iki 0,95 , t. y. apie $5 \%$ (3.20 pav.). Šie faktai rodo, kad grịžtamojo transformatoriaus pirminès apvijos aktyvinès varžos mažinimas leidžia efektyviai pagerinti tiriamo mikroinverterio naudingumo koeficientą. 


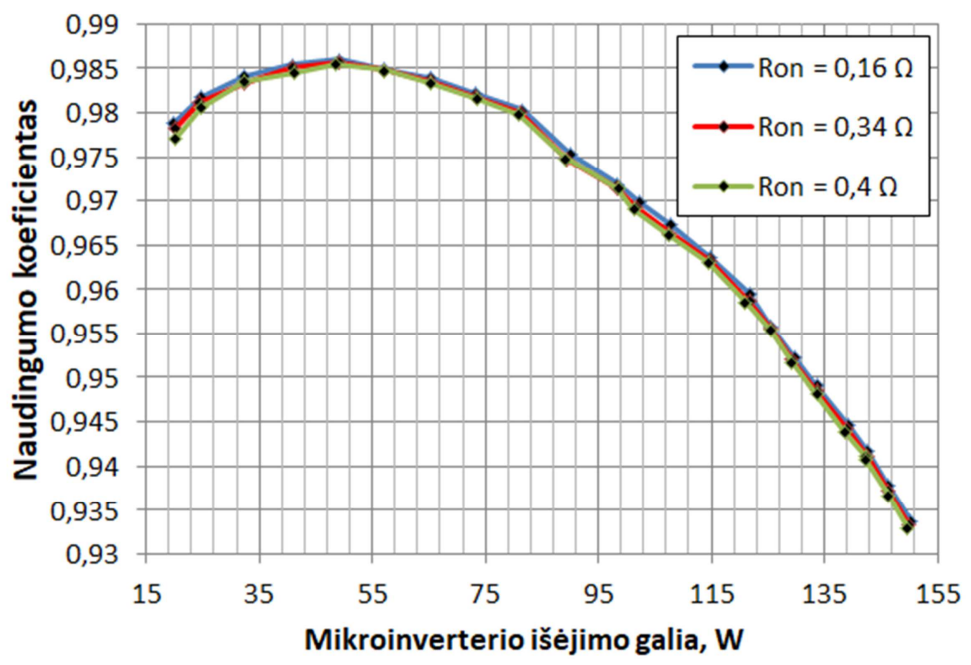

3.18 pav. Mikroinverterio su LCL filtru naudingumo koeficiento priklausomybė nuo galios, esant skirtingoms raktų Q5, Q6 parametro $R_{\text {on }}$ vertèms

Fig. 3.18. Efficiency dependences on the output power of microinverter with the LCL low pass output filter for various values of switches Q5, Q6 parameter $R_{\text {on }}$

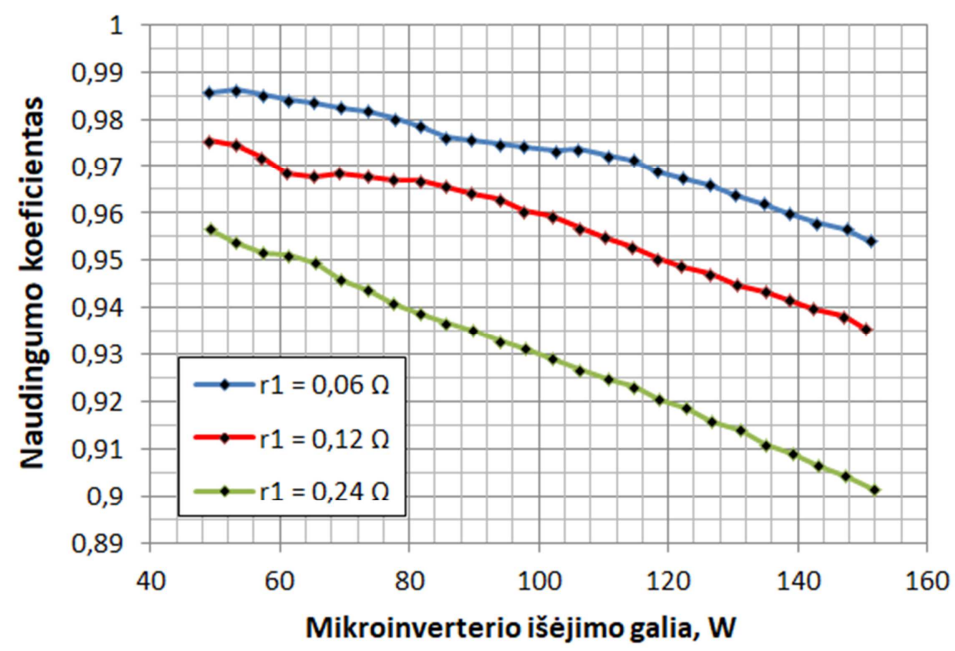

3.19 pav. Mikroinverterio su CL filtru naudingumo koeficiento priklausomybė nuo galios, esant skirtingoms grịžtamojo transformatoriaus pirminès apvijos aktyvinès varžos $r_{1}$ vertèms

Fig. 3.19. Efficiency dependences of the microinverter with the CL filter on the output power for various primary winding active resistances $r_{1}$ of flyback transformer 


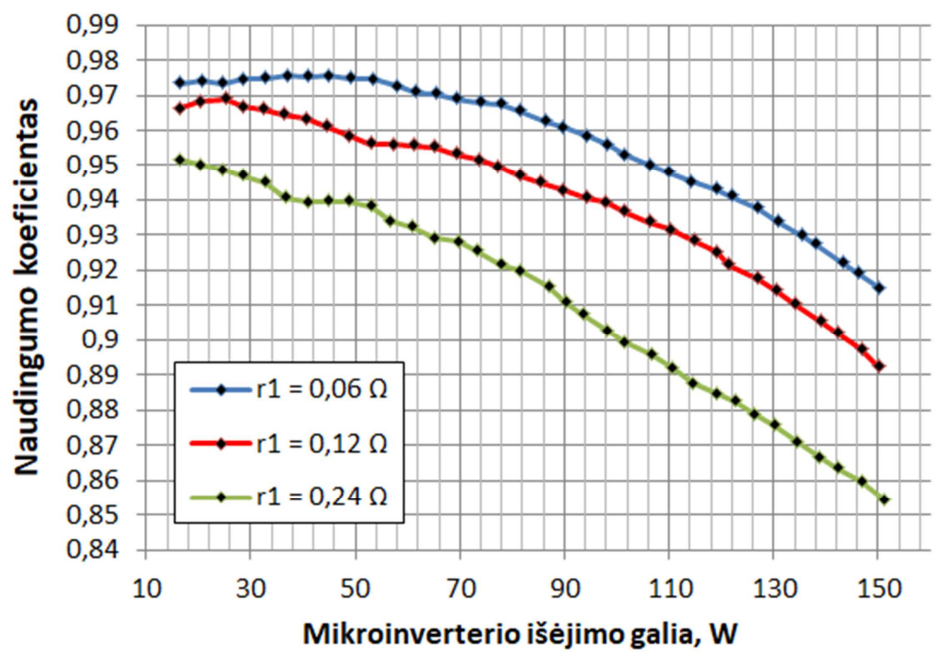

3.20 pav. Mikroinverterio su LCL filtru naudingumo koeficiento priklausomybè nuo galios esant skirtingoms grịžtamojo transformatoriaus pirminès apvijos aktyvinès varžos $r_{1}$ vertèms

Fig. 3.20. Efficiency dependences of the microinverter with the LCL filter on the output power for various primary winding active resistances $r_{1}$ of flyback transformer

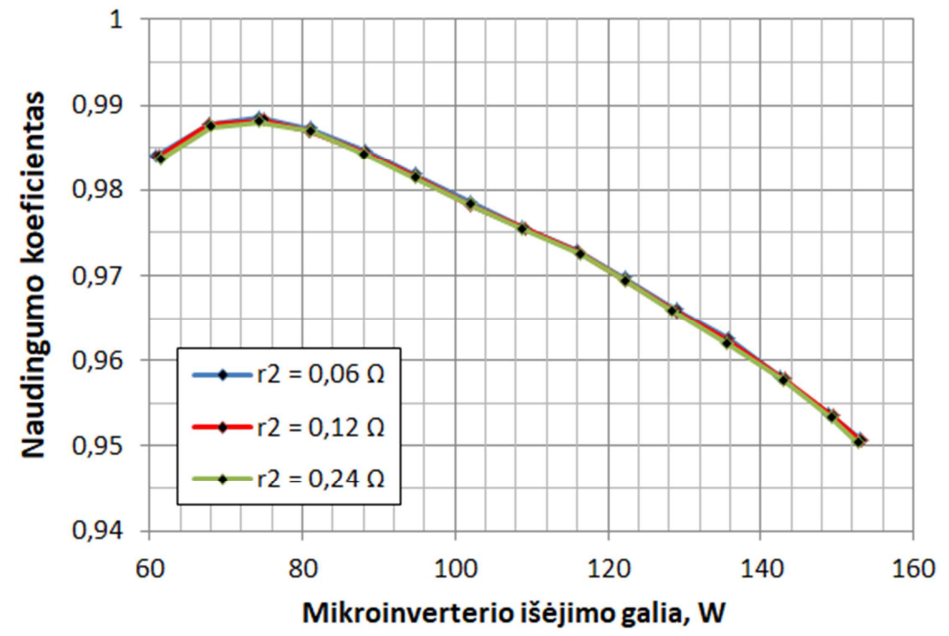

3.21 pav. Mikroinverterio su CL filtru naudingumo koeficiento priklausomybè nuo galios, esant skirtingoms grịžtamojo transformatoriaus antrinès apvijos aktyvinės varžos $r_{2}$ vertèms

Fig. 3.21. Efficiency dependences of the microinverter with the CL filter on the output power for various secondary winding active resistances $r_{2}$ of flyback transformer 


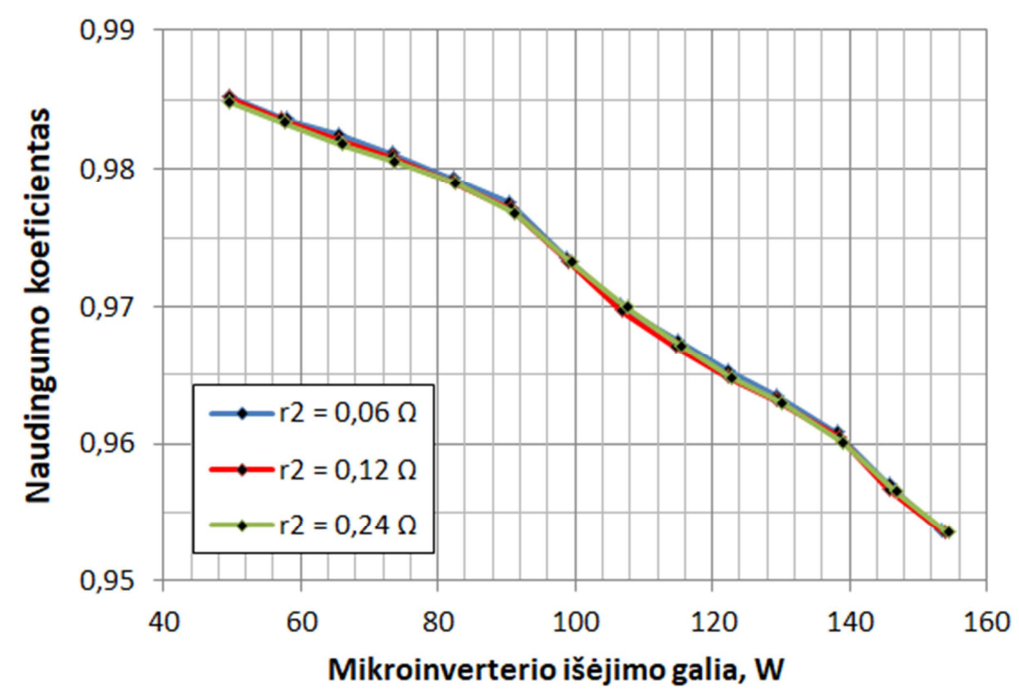

3.22 pav. Mikroinverterio su LCL filtru naudingumo koeficiento priklausomybė nuo galios, esant skirtingoms grįžtamojo transformatoriaus antrinès apvijos aktyvinès varžos $r_{2}$ vertèms

Fig. 3.22. Efficiency dependences of the microinverter with the LCL filter on the output power for various secondary winding active resistances $r_{2}$ of flyback transformer

Mikroinverterio naudingumo koeficiento priklausomybès nuo generuojamos i elektros tinklą galios ịvairioms grịžtamojo transformatoriaus antrinès apvijos aktyvinès varžos $r_{2}$ vertėms, kai naudojamas CL išèjimo filtras, pateiktos 3.21 paveiksle. Gauti rezultatai rodo, kad mikroinverterio naudingumo koeficientas keičiantis antrinès apvijos aktyvinei varžai nuo 0,06 iki $0,24 \Omega$, sumažèja ne daugiau kaip $0,1 \%$, t. y. priklauso nežymiai. Panašūs rezultatai gauti ir atveju, kai mikroinverteryje naudojamas LCL išèjimo filtras (3.22 paveikslas), t. y. $r_{2}$ vertè mažai įtakoja mikroinverterio naudingumo koeficientą. Taip yra dèl to, kad tai yra ịtampą aukštinantis transformatorius ir jo antrinès apvijos srovè yra maža, lyginant su pirminès apvijos srove. Projektuojant grịžtamojo tipo transformatorių reikètų antrinę apviją daryti kiek galima kompaktiškesnę, vyniojant ją iš plono laidininko tam, kad palikti daugiau vietos pirminei apvijai, nuo kurios laidininko diametro mikroinverterio naudingumo koeficientas stipriai priklauso. 


\subsection{Grižtamojo transformatoriaus vienos pakopos mikroinverteriui tobulinimas}

Grižtamasis transformatorius yra vienas iš svarbiausių sukurto vienos pakopos mikroinverterio komponentų. Praeitame skyriuje buvo pateikti transformatoriaus pirminès ir antrinès apvijų aktyvinès varžos įtakos tyrimai mikroinverterio naudingumo koeficientui. Tačiau naudingumo koeficientą įtakoja ir grịžtamojo transformatoriaus apvijų išdèstymas transformatoriaus konstrukcijoje. Šiame skyriuje pateikti transformatoriaus tobulinimo ir jo itakos naudingumo koeficientui tyrimo rezultatai.

Grị̌tamajame transformatoriuje pasireiškia parazitiniai srauto sklaidos reiškiniai magnetinèje sistemoje (angl. leakage inductance) (Ouyang et al. 2015, Leuenberger et al. 2015), dèl kurių komutuojant transformatoriaus pirminę apviją, jos atjungimo metu išauga sukuriami viršitampiai. Viršịtampių generavimui naudojama energija, todèl kuo aukštesnès amplitudes viršĭtampis sukuriamas, tuo didesni gaunasi energijos nuostoliai. Dažniausiai grįžtamojo tipo transformatoriaus tyrimai atliekami naudojant modeliavimą. Tačiau teoriniai modeliai nèra tikslūs, jie neįvertina konstruktyvinių transformatoriaus ypatumų. Modeliuojant būtina žinoti tikslų apvijų tarpusavio magnetinị ryšị, kuris priklauso nuo sudètingos magnetinès sistemos savybių ir apvijų išdėstymo. Tikslias šių parametrų vertes nustatyti yra sudètinga (Holguin 2015 et al.), todèl norint gauti patikimus tyrimu rezultatus tikslingai yra naudoti eksperimentini tyrimą.

\subsubsection{Magnetinio srauto sklaidos susidarymo priežastys}

Grį̌tamojo transformatoriaus šerdis turi oro tarpą (3.23 paveikslas). Jis naudojamas tam, kad padidinti srovę, prie kurios transformatorius pradeda issisotinti. Dèl oro tarpo transformatoriaus magnetinèje grandinèje, tarp pirminès ir antrinès apvijos susietasis magnetinis laukas nèra toks stiprus kaip magnetinejje grandinejje be oro tarpo ir ne visas pirminès apvijos sukuriamas kintamasis magnetinis laukas veria antrinès apvijos vijas. Dalis kintamo magnetinio lauko kuriamos magnetovaros (angl. magnetomotive force) atsiranda už transformatoriaus magnetinès šerdies ribų ir oro tarpuose veria apvijas (Ouyang et al. 2015, Holguin et al. 2015). Šios ne šerdyje esančios magnetinio srauto linijos kuria magnetinio srauto sklaidos reiškinį. Dèl magnetinio srauto sklaidos pirminejje apvijoje, ją komutuojant, kuriama saviindukcinė elektrovara viršitampis (3.24 pav.), kuris pasiduoda ị mikroinverterio raktus.

Sklaidos srautą $\Phi_{\mathrm{S}}$ kurianti magnetovara $F(x)$ susidaro tarp apvijų oro tarpuose (Ouyang et al. 2015). Šis sklaidos srautas priklauso nuo pirminès ir 
antrinès apvijų tarpusavio padèties transformatoriaus apvijų karkase; apvijų tarpusavio atstumo, apvijų kiekio. Magnetovara oro tarpe apskaičiuojama pagal formulę:

$$
F(x)=H(x) l_{w},
$$

čia $H(x)$ - magnetinio lauko stipris; $l_{\mathrm{w}}$ - transformatoriaus magnetolaidžio šerdies ilgis.

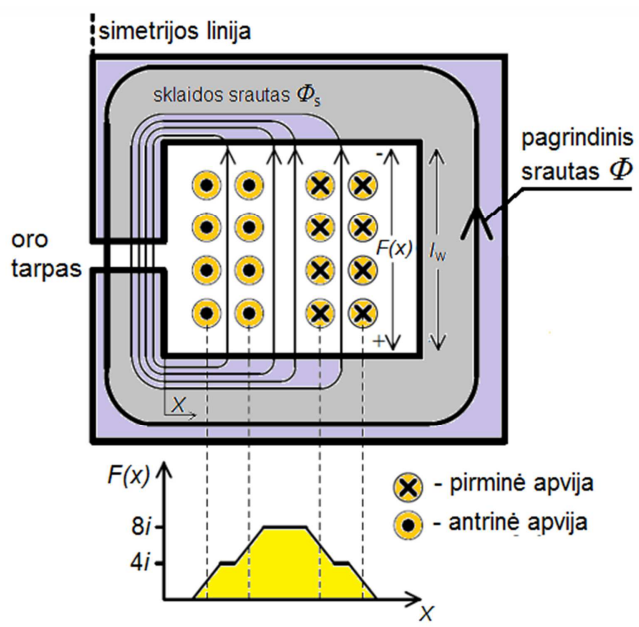

3.23 pav. Magnetovaros jègos grižtamajame transformatoriuje

Fig. 3.23. Magnetomotive force in the flyback transformer

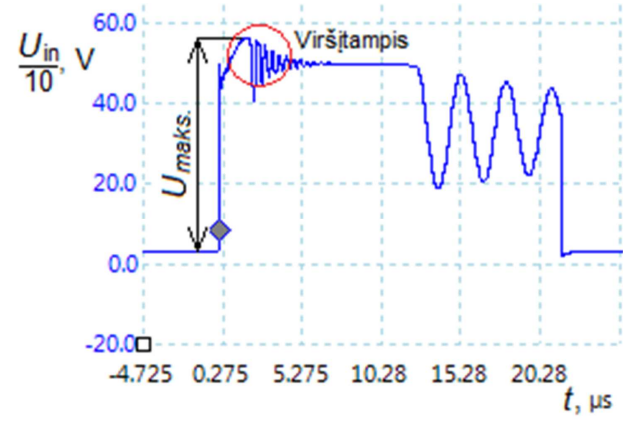

3.24 pav. Mikroinverterio su grị̌tamuoju transformatoriumi raktų tranzistorių santakosištakos įtampos pereinamasis procesas

Fig. 3.24. Transient of drain-source voltage of flyback microinverter MOSFET switch transistor

Magnetiniai sklaidos srautai atsiranda tarp apvijų oro tarpuose ir priklauso nuo kuriamos apvijų magnetovaros jègos. Kaip matyti iš 3.23 paveikslo, antrine 
apvija tekanti srovè kuria priešingos krypties magnetovarą ir slopina magnetinio srauto sklaidos reiškinị. Tačiau tarp pirminès ir antrinès apvijų esantis oro tarpas yra maksimaliai įmagnetintas - ten koncentruojasi didžiausi sklaidos magnetiniai srautai, mažinantys apvijų tarpusavio magnetinị ryšį.

Oro tarpas šerdies centre taip pat daro įtaką sklaidos magnetinio srauto didejjimui, didindamas magnetovaržą pagrindiniam transformatoriaus magnetiniam srautui, todèl apvijų tarpusavio ryšys tampa dar silpnesnis.

\subsubsection{Grįžtamojo transformatoriaus magnetinio srauto sklaidos reiškinių ịtakos keitiklio darbui tyrimas}

Tyrimui atlikti parinktas ETD-34 tipo feritinis magnetolaidis iš standartinès N27 numeriu pažymètos medžiagos, kuri dažniausiai naudojama pramoniniuose ir buitiniuose impulsiniuose keitikliuose. Kad tyrimo metu būtų galima keisti oro tarpo parametrus, buvo paimtos kelios šerdys su skirtingomis centrinès magnetolaidžio išpjovomis nuo 0 iki $1 \mathrm{~mm}$ (3.25 paveikslas).

Grįžtamojo transformatoriaus komutavimo sąlygojamų viršįtampių tyrimui ir būdams jų mažinimui rasti, transformatorius buvo komutuojamas naudojant maketą, kurio schemą pateikta 3.26 paveiksle. Raktas valdomas valdiklio mikroschema UC3843. Rakto valdiklis formuoja impulsinị signalą, tiekiamą i rakto tranzistorių Q1. Jis taip pat seka ịtampą, kuri gaunama išlyginus antrinės transformatoriaus apvijos kintamają įtampa ir, keisdamas impulsų skvarbą, palaiko nustatytą jos vertę. Tai pat valdiklis leidžia parinkti norimą impulsų, dažnį. Maketo komponentų sąrašas ir komponentų parametrai pateikti 3.4 lenteleje.

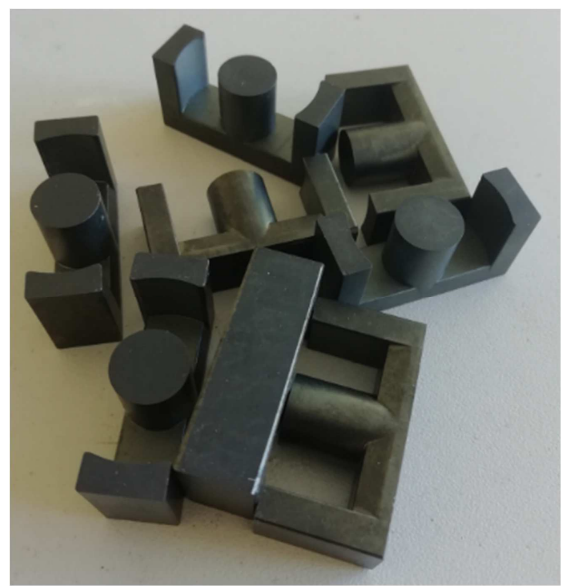

3.25 pav. ETD-34 feritinis magnetolaidis

Fig. 3.25. ETD-34 ferrite magnetic core 
Grįžtamojo transformatoriaus tyrimų makete (3.26 pav.) numatyta pasyvioji viršitampių slopinimo grandinè (anlg. clamp circuit), kurią sudaro R1, C1 ir D2 elementai. Ši grandinè yra svarbi mikroinverteryje su grịžtamuoju transformatoriumi, nes ji mažina viršitampi iki nepavojingos rakto tranzistoriui, komutuojančiam transformatoriaus pirminę apviją, ribos. Slopinimas vykdomas viršịtampio energiją sukaupiant kondensatoriuje $\mathrm{C} 1$ ir verčiant $\mathfrak{i}$ šilumą rezistoriuje R1.

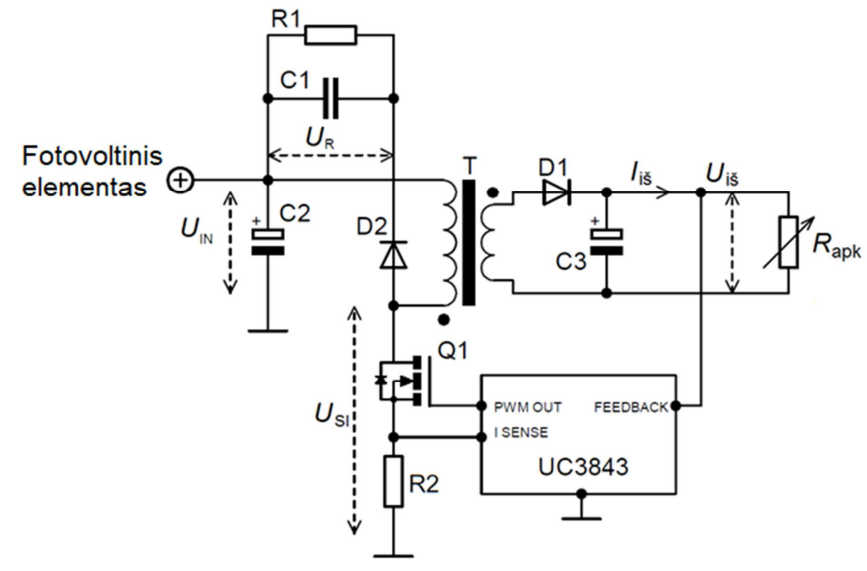

3.26 pav. Grįžtamojo transformatoriaus tyrimo maketo principinė elektrinè schema Fig. 3.26. Circuit diagram of flyback transformer test bench

3.4. lentelè. Grį̌tamojo transformatoriaus tyrimo maketo komponentai Table 3.4. Components of flyback transformer test bench

\begin{tabular}{|l|l|}
\hline Komponentas & Parametrai \\
\hline $\mathrm{C} 1$ & $10 \mathrm{nF}, 450 \mathrm{~V}$ \\
\hline $\mathrm{C} 2$ & $1200 \mu \mathrm{F}, 400 \mathrm{~V}$ \\
\hline $\mathrm{C} 3$ & $4700 \mu \mathrm{F}, 35 \mathrm{~V}$ \\
\hline $\mathrm{R} 1$ & $3,3 \mathrm{~K} \Omega, 10 \mathrm{~W}$ \\
\hline $\mathrm{R} 2$ & $0,22 \Omega, 2 \mathrm{~W}$ \\
\hline Q1 & K2717 $(900 \mathrm{~V}, 5 \mathrm{~A})$ \\
\hline D1 & MUR1560 (600 V, 15 A) \\
\hline D2 & BY228 $(1500 \mathrm{~V}, 5 \mathrm{~A})$ \\
\hline
\end{tabular}


Sklaidos srauto sukurtos saviindukcinès elektrovaros (viršitampio) kuriamus nuostolius galima apskaičiuoti žinant vidutinị ịtampos kritimą R1 rezistoriuje pagal formulę:

$$
P_{\text {nuost }}=\frac{U_{\mathrm{R} 1}^{2}}{R_{1}}=\frac{\left(U_{\text {sklaidos }}+\left(U_{\mathrm{D} 1}+U_{\mathrm{irs}} \frac{n_{1}}{n_{2}}\right)\right)^{2}}{R_{1}},
$$

čia $U_{\text {sklaidos }}-$ sklaidos srauto kuriama ịtampa (viršitampis); $U_{\mathrm{D} 1}-$ ịtampos kritimas ant diodo D1; $U_{\text {ǐ̆ }}$ - keitiklio išèjimo ịtampa; $n_{1}, n_{2}$ - pirminès ir antrinès grižtamojo transformatoriaus apvijų vijų kiekis.

İtampos kritimą $U_{\mathrm{R} 1}$ sudaro (3.7) dvi komponentès:

1. Magnetinio sklaidos srauto pereinamojo proceso metu kuriama elektrovara $U_{\text {sklaidos. }}$

2. Pastovaus dydžio ịtampos kritimas. Jis yra neišvengiamas ir yra apspręstas išèjimo ịtampos ir transformatoriaus pirminès ir antrinès apvijų viju santykio bei įtampos kritimo diode D1.

Pastovioji nuostolių dalis slopinančioje grandinèje nesikeičia, kintant galiai tiekiamai ị apkrovą $R_{\text {apk }}$, keičiasi tik sklaidos srauto kuriamų nuostolių dedamoji, todèl išsklaidomos galios kitimas slopinančioje grandinèje yra apsprendžiamas nuostolių, kurie yra sąlygojami sklaidos srauto reiškinio. Tokiu būdu, tiriant nuostolių kitimą slopinančioje grandinèje galima ịvertinti nuostolius sukeliamus viršitampių, kuriuos sąlygoja sklaidos srautas.
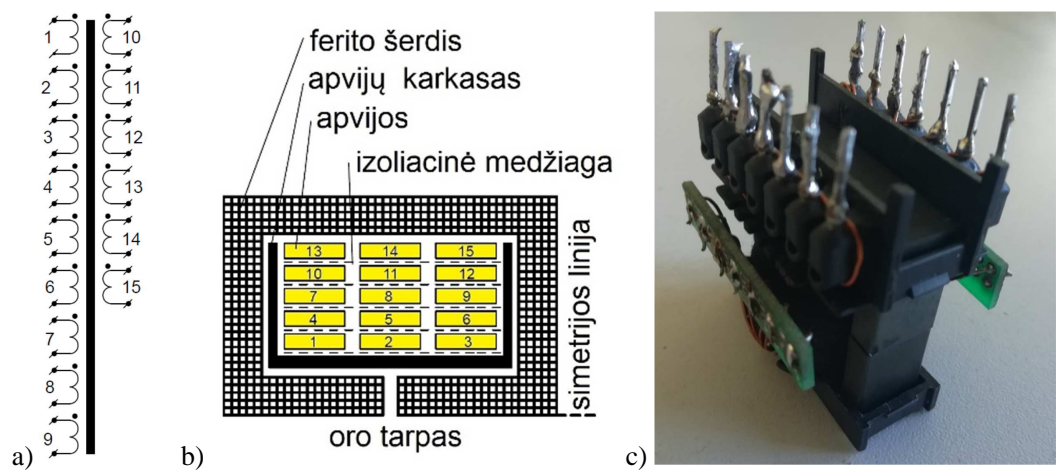

3.27 pav. Tiriamojo grižtamojo transformatoriaus: a) apvijų principinè elektrinė schema; b) apvijų išdėstymas transformatoriaus korpuse; c) bendras vaizdas

Fig. 3.27. Design of flyback transformer experimental model: a) circuit diagram of windings; b) windings of the bobbin; c) general view of transformer 
3.5 lentelè. Apvijų tarpusavio sujungimo būdai

Table 3.5. Transformer windings connection ways

\begin{tabular}{|l|l|l|}
\hline $\begin{array}{l}\text { Vijų kiekis antrinėje } \\
\text { apvijoje }\end{array}$ & $\begin{array}{l}\text { Antrinės apvijos vijos } \\
\text { sujungtos nuosekliai }\end{array}$ & $\begin{array}{l}\text { Pirminės apvijos vijos } \\
\text { sujungtos lygiagrečiai }\end{array}$ \\
\hline 1 & 4 & $1 ; 2 ; 3 ; 7 ; 8 ; 9$ \\
\hline 2 & $4 ; 5$ & $1 ; 2 ; 3 ; 7 ; 8 ; 9$ \\
\hline 3 & $4 ; 5 ; 6$ & $1 ; 2 ; 3 ; 7 ; 8 ; 9$ \\
\hline $6^{*}$ & $4 ; 5 ; 6 ; 7 ; 8 ; 9 *$ & $1 ; 2 ; 3 ; 10 ; 11 ; 12 *$ \\
\hline 9 & $4 ; 5 ; 6 ; 7 ; 8 ; 9 ; 10 ; 11 ; 12$ & $1 ; 2 ; 3 ; 13 ; 14 ; 15$ \\
\hline
\end{tabular}

Tyrimams buvo pasigamintas grịžtamasis transformatorius, turintis 15 nepriklausomų apvijų po 10 vijų varinio laido, kurio skerspjūvio plotas $0,6 \mathrm{~mm}^{2}$ (3.27 pav.). Transformatoriaus vijos buvo sujungiamos įvairiais būdais, kurie pateikti 3.5 ir 3.6 lentelèse.

Pirmame eksperimente buvo tiriama galios nuostolių slopinančioje grandinèje priklausomybė nuo tiekiamos galios ị apkrovą $R_{\text {apk }}$ prie ịvairių rakto komutavimo dažnių: 25; 35; 50; $65 \mathrm{kHz}$. Eksperimentas atliktas esant $0,7 \mathrm{~mm}$ grịžtamojo transformatoriaus šerdies oro tarpui. Pirminès ir antrinès tarpusavio apvijų sujungimo būdai pavaizduoti 3.5 lentelès, eilutėje pažymètoje žvaigždutės simboliu. Gauti rezultatai pavaizduoti 3.28 paveiksle.

3.6 lentelè. Apvijų tarpusavio sujungimo būdai

Table 3.6. Transformer windings connection ways

\begin{tabular}{|l|l|l|}
\hline Jungimo būdas & $\begin{array}{l}\text { Antrinės apvijos vijos, } \\
\text { nuosekliai }\end{array}$ & $\begin{array}{l}\text { Pirminės apvijos vijos, } \\
\text { lygiagrečiai }\end{array}$ \\
\hline 1 & $7,8,9,10,11,12$ & $1,2,3,4,5,6$ \\
\hline 2 & $1,2,3,4,5,6$ & $7,8,9,10,11,12$ \\
\hline 3 & $1,2,3,10,11,12$ & $4,5,6,7,8,9$ \\
\hline 4 & $4,5,6,7,8,9$ & $1,2,3,10,11,12$ \\
\hline 5 & $4,5,6,10,11,12$ & $1,2,3,7,8,9$ \\
\hline 6 & $1,3,5,7,9,11$ & $2,4,6,8,10,12$ \\
\hline 7 & $1,4,5,7,10,11$ & $2,3,6,8,9,12$ \\
\hline
\end{tabular}

Gautuose rezultatuose matyti, kad prie galios, kuri neviršija $80 \mathrm{~W}$, mažiausi nuostoliai yra gaunami prie mažiausio raktų komutavimo dažnio. Tačiau toliau didinant galią šerdis pradeda sotintis, dèl ko ima didèti magnetinio srauto 
sklaida, kuri sąlygoja spartų nuostolių viršįtampi gesinančioje grandinèje didejjimą. Prie $98 \mathrm{~W}$ apkrovos galios nuostolių galia padideja 1,6 karto, lyginant su nuostoliais prie $80 \mathrm{~W}$.

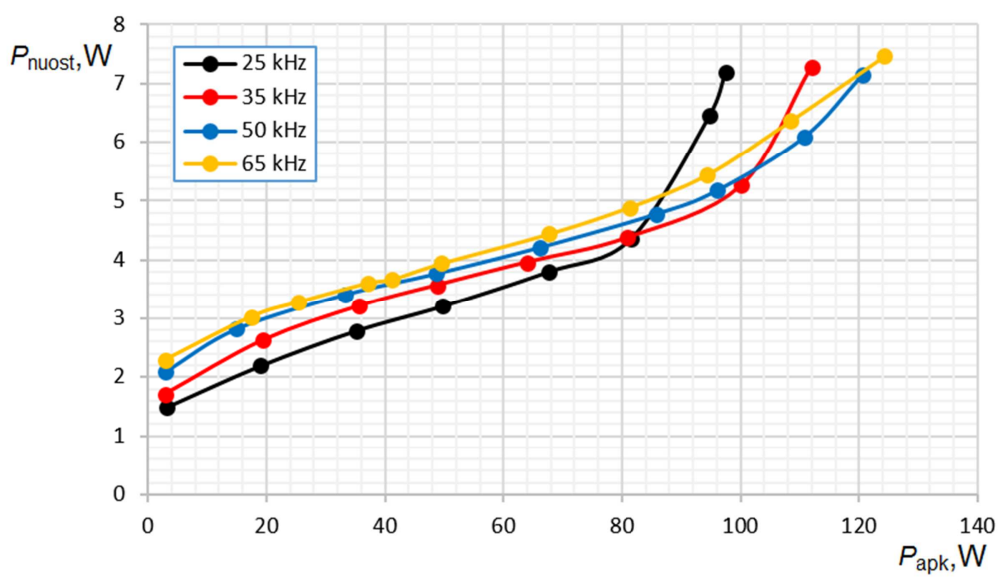

3.28 pav. Galios nuostolių slopinančioje grandinëje priklausomybès nuo tiekiamos galios į apkrovą, esant skirtingiems raktų komutavimo dažniams

Fig. 3.28. The dependences of power losses in the clamping circuit on the output power at various carrier frequencies

Didinat raktų komutavimo dažnį, grịžtamojo transformatoriaus šerdies sotinimosi taškas pasiekiamas prie didesnès keitiklio apkrovos galios gaunamas didesnis transformatoriaus išnaudojimas - geresnis keitiklio galios ir masès santykis. Padidinus dažnį nuo $25 \mathrm{kHz}$ iki $50 \mathrm{kHz}$ su tokių pat parametrų transformatoriumi galima pasiekti iki $25 \%$ didesnès galios.

Kitas eksperimentas atliktas prie įvairių grįžtamojo transformatoriaus oro tarpų: $0 ; 0,2 ; 0,7 ; 1 ; 1,5 ; 2 \mathrm{~mm}$. Gauti rezultatai pateikti 3.29 paveiksle. Jie gauti $35 \mathrm{kHz}$ rakto komutavimo dažniui. Pirminès ir antrinès apvijų sujungimo būdai pavaizduoti 3.5 lenteleje žvaigždutès simboliu. Esant mažam oro tarpui $(0 \mathrm{~mm}$ (tarpo nèra) ir $0,2 \mathrm{~mm}$ ), feritinè transformatoriaus šerdis sotinimosi tašką pasiekia prie santykinai mažų išèjimo galių. Toliau didinant oro tarpą $(0,7 ; 1$; 1,5; $2 \mathrm{~mm}$ ), šerdis įsisotina prie didesnių apkrovimo galių (3.29 pav.). Mažiausi galios nuostoliai pasiekiami esant $0,7 \mathrm{~mm}$ oro tarpui.

Didinat oro tarpa nuo 0,2 iki $0,7 \mathrm{~mm}$, galia prie kurios transformatorius pradeda sotintis padidejja dvigubai, t. y. mikroinverteris gali dirbti prie dvigubai didesnès išèjimo galios. Tačiau dar labiau didinat oro tarpą, pasiekiama riba, kai magnetinio lauko sklaidos srauto reiškiniai kuria ženklius galios nuostolius, tai ịrodo dèsningai didejjantys galios nuostoliai slopinančioje grandinèje, didinant toliau oro tarpą magnetolaidyje nuo 1 iki $2 \mathrm{~mm}$ (3.29 pav.). 


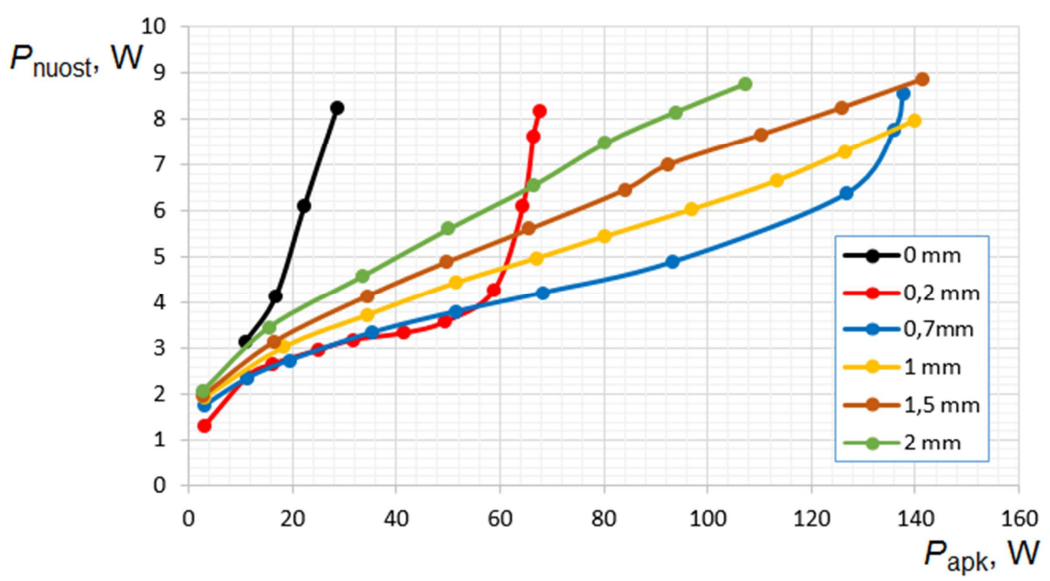

3.29 pav. Galios nuostolių slopinančioje grandinèje priklausomybės nuo tiekiamos galios į apkrovą, esant skirtingiems oro tarpams transformatoriaus magnetinèje sistemoje Fig. 3.29. The dependences of power losses in the clamping circuit on the output power at various widths of flyback transformer air gap

Sekančiame eksperimente ištirta kaip priklauso nuostoliai viršįtampio slopinimo grandinėje nuo lygiagrečiai sujungtų apvijų, iš kurių sudaryta antrinė transformatoriaus apvija, kiekio. Tyrimas atliktas kai raktas Q1 komutuojamas $35 \mathrm{kHz}$ dažniu, esant $1 \mathrm{~mm}$ oro tarpui transformatoriaus šerdyje. Pirminių ir antrinių apvijų sujungimo tvarka nurodyta 3.5 lentelèje. Gauti rezultatai pavaizduoti 3.30 paveiksle.

Iš gautų rezultatų matyti, kad grižtamojo transformatoriaus generuojami nuostoliai slopinančioje grandinèje, naudojant 1 arba 2 lygiagrečiai sujungtas apvijas antrinejje transformatoriaus apvijoje, yra didesni, lyginant su atvejais kai lygiagrečiai jungiamos 3-6 apvijos. Pavyzdžiui, kai keitiklio apkrovimo galia $53 \mathrm{~W}$, jungiant vieną antrinę apviją nuostoliai yra iki 3,3 kartų didesni nei jungiant lygiagrečiai tris antrines apvijas.

Gautus rezultatus galima paaiškinti magnetovaros veikimu oro tarpuose tarp apvijų (3.27 pav.). Vienos vijos atveju, tarp pirminès ir antrinès apvijų oro tarpe kuriama magnetovara yra silpnai slopinama antrinès apvijos, nes (3.27 pav. b) apvija yra vijų karkaso krašte ir slopina oro tarpe esančias magnetovaras, kurias kuria tik 1-a ir 7-a apvijos, o 2-os, 3-os, 8-os, 9-os vijų magnetovaros oro tarpuose nèra slopinamos ir kuria ženklią magnetinio lauko srauto sklaidą.

Kai antrinę apviją sudaro trys lygiagrečiai sujungtos apvijos, tuomet visos pirminès apvijos karkase (3.27 pav. b) perdengiamos antrinėmis. Gaunamas efektyvesnis pirminių vijų perdengimas antrinèmis vijomis, todèl magnetinio sklaidos srauto slopinimas tampa efektyvesnis. Tokiu būtu išdèstytos apvijos efektyviau ,paima“" energiją iš pirminès grandinès, tai patvirtina eksperimentinio 
tyrimo rezultatai (3.30 pav.). Jungiant lygiagrečiai daugiau nei 3 vijas sklaidos srauto kuriami nuostoliai mažèja nežymiai.

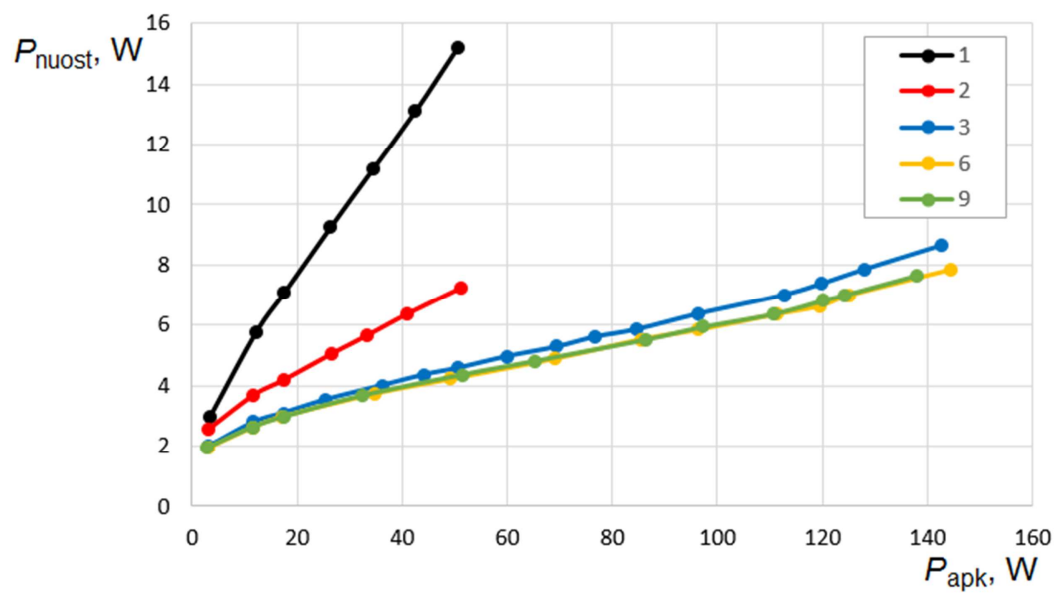

3.30 pav. Galios nuostolių slopinančioje grandinèje priklausomybė nuo tiekiamos galios i apkrovą, esant skirtingiems antrinès apvijos lygiagrečiai jungtų apvijų kiekiams

Fig. 3.30. The dependence of power losses in the clamping circuit on the output power at various number of secondary windings connected in paralel.

Kitame eksperimente ištirta, kaip priklauso sklaidos srauto kuriami nuostoliai slopinančioje grandinejje, esant skirtingiems pirminès ir antrinès apvijų tarpusavio išdèstymo būdams apvijų karkase. Eksperimentas atliktas kai raktas Q1 komutuojamas $35 \mathrm{kHz}$ dažniu, esant $0,7 \mathrm{~mm}$ oro tarpui transformatoriaus šerdyje. Tyrimui pasirinkti šie apvijų sujungimo būdai:

- 1 ir 2 būdai - išdèstant apvijas viena ant kitos.

- 3 būdas - pirminę apviją apgaubiant antrine apvija.

- 4 būdas - antrinę apviją apgaubiant pirmine.

- 5 būdas - pirminę ir antrinę apvijas išdèstant sluoksniuotai.

- 6 būdas - pasiūlytas disertacijos autoriaus, kai pirminè ir antrinè apvijos karkase išdèstomos šachmatų lentos principu.

- 7 būdas - išdėstant pirminę ir antrinę apvijas karkaso šonuose.

Apvijų išdèstymas karkase ir sujungimas pateiktas 3.6 lentelèje. Eksperimento metu pirminès apvijos jungiamos nuosekliai, antrinès lygiagrečiai. Gauti rezultatai pavaizduoti 3.31 paveiksle. 
1 ir 2-uoju apvijų tarpusavio sujungimo būdais sklaidos srauto kuriami nuostoliai slopinančioje grandinejje prie $140 \mathrm{~W}$ apkrovimo galios yra $8 \%$ didesni lyginant su alternatyviais 3, 4 būdais, kai apvijos buvo dalinai sluoksniuojamos (pirmines apvijas perdengiant antrinėmis ir atvirkščiai).

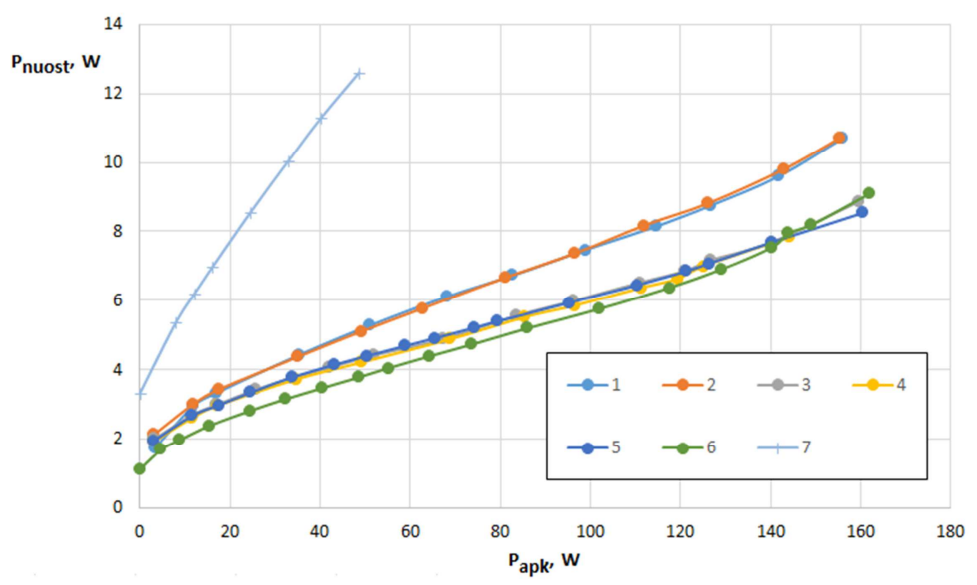

3.31 pav. Galios nuostolių slopinančioje grandinèje priklausomybė nuo tiekiamos galios i apkrovą, esant skirtingiems apvijų sujungimo būdams

Fig. 3.31. The dependence of power losses in the clamping circuit on the output power at various transformer windings wiring ways.

Naudojant 5-ajį būdą, kai apvijos buvo pilnai sluoksniuotos karkase, gauti rezultatai praktiškai sutampa su 3 ir 4 būdų rezultatais.

Pasiūlytuoju, t. y. 6-tuoju jungimo būdu, kai apvijos karkase buvo išdėstytos „šachmatų lentos“ principu, gauti galios nuostoliai slopinančioje grandinejje yra mažiausi. Prie $100 \mathrm{~W}$ apkrovimo galios nuostoliai yra 4,2 \% mažesni nei gauti 3 ir 4-uoju sujungimų būdais ir 29,3\% mažesni nei gauti naudojant 1 ir 2 jungimo būdus.

Naudojant 7 būdą, kai pirminè ir antrinè apvijos išdèstytos karkaso šonuose - gauti rezultatai blogiausi. Šiuo atveju nuostoliai padideja dèl to, kad magnetinio srauto sklaida koncentruojasi apvijos galuose.

\subsection{Trečiojo skyriaus išvados}

1. Proporcinis PI valdiklio koeficientas turi būti keičiamas proporcingai mikroinverterio išèjimo srovei, kad būtų sumažintos išèjimo srovès aukšto dažnio pulsacijos ir tuo pat metu jos forma nebūtų iškraipyta žemo dažnio harmonikomis. 
2. Pasiūlyto PI valdiklio su keičiamu laike proporciniu koeficientu naudojimas leidžia sumažinti mikroinverterio išejimo srovès netiesinius iškraipymus iki $30 \%$ esant $32 \mathrm{~W}, 48 \%$ esant $62 \mathrm{~W}$ ir $40 \%$ esant $97 \mathrm{~W}$ galiai tiekiamai ị elektros tinklą kai tinklo įtampos forma neiškraipyta ir $7 \%$ esant $32 \mathrm{~W}, 33 \%$ esant $62 \mathrm{~W}$ ir $26 \%$ esant $97 \mathrm{~W}$ apkrovos galiai kai tinklo įtampa iškraipyta 3-ja ir 5-ja harmonikomis.

3. Sumažinus grižtamojo transformatoriaus pirminès apvijos aktyvinę varžą nuo 0,24 iki $0,06 \Omega$, mikroinverterio naudingumo koeficientas išauga $4 \%$, o pakeitus inverterio MOSFET raktų tranzistorius, kurių atviro tranzistoriaus varža yra $0,12 \Omega$, i tranzistorius su $0,04 \Omega$ varža, naudingumo koeficientas išauga $1 \%$, kai mikroinverterio tiekiama ị elektros tinklą galia yra $100 \mathrm{~W}$. Tuo tarpu tiek pat sumažinus grịžtamojo transformatoriaus antrinès apvijos aktyvinę varžą ir joje naudojamų MOSFET raktų atviro tranzistoriaus varžą, mikroinverterio naudingumo koeficientas išauga atitinkamai $0,1 \%$ ir $0,03 \%$.

4. Grįžtamojo transformatoriaus apvijų išdėstymo būdas pasiūlytuoju „šachmatų lentos“ metodu leidžia sumažinti komutacinių viršịtampių sąlygojamus galios nuostolius ịtampą slopinančioje grandinèje nuo 4,2 \% iki 29,3\%, lyginant su kitais žinomais apvijų išdèstymo metodais, kai išèjimo galia $100 \mathrm{~W}$. 


\section{Bendrosios išvados}

1. Sukurtas nuolatinès įtampos grįžtamasis keitiklis su dvejais raktais, lyginant su klasikiniu, turi mažiau elektronikos komponentų, jame naudojamas paprastesnis lauko tranzistorių valdymas. Šio keitiklio naudingumo koeficientas prie $80 \mathrm{~W}$ galios, kai raktų komutavimo dažnis $36 \mathrm{kHz}$, siekia 0,918 , tuo tarpu klasikinio - 0,895, t. y. 2,3\% didesnis.

2. Sukurto vienos pakopos mikroinverterio naudingumo koeficientas, veikiant tinklo režimu, pasiekia didžiausią 0,94 vertę, esant $36 \mathrm{kHz}$ raktų komutavimo dažniui ir $45 \mathrm{~W}$ išejimo galiai.

3. Pasiūlytas PI valdiklis su keičiamu laike proporciniu koeficientu, lyginant su klasikiniu PI valdikliu, leidžia sumažinti mikroinverterio išejimo srovès netiesinius iškraipymus ne mažiau kaip $30 \%$, kai tinklo ịtampa neiškraipyta ir ne mažiau kaip $7 \%$, kai tinklo ịtampa iškraipyta 3-ja ir 5-ja harmonikomis.

4. Mikroinverterio naudingumo koeficientą galima padidinti sumažinus grižtamojo transformatoriaus pirminès apvijos aktyvinę varžą ir inverterio MOSFET raktų atviro tranzistoriaus varžą, tuo tarpu grižtamojo transformatoriaus antrinès apvijos aktyvinė varža ir 
joje naudojamų MOSFET raktų atviro tranzistoriaus varža mikroinverterio naudingumo koeficiento neįtakoja.

5. Komutacinių viršitampių sąlygojami galios nuostoliai ịtampą slopinančioje grandinèje yra mažiausi, kai apvijos yra išdèstytos siūlomu ,šachmatų lentos“ principu. 


\section{Literatūra ir šaltiniai}

Aalami, M., Babaei, E., Sabahi, M. 2018. Design of a new combined cascaded multilevel inverter based on developed H-bridge with reduced number of IGBTs and DC voltage sources, in 2018 IEEE 12th International Conference on Compatibility, Power Electronics and Power Engineering, Doha, Qatar , 1-6.

Abunima, H., The J., Jabir, H. J. 2019. A New Solar Radiation Model for a Power System Reliability Study," in IEEE Access, vol. 7, pp. 64758-64766, doi: 10.1109/ACCESS.2019.2916168.

Acharya, P. P., Rangras, V. S. 2014. Modified sine wave phase disposition PWM technique for harmonic reduction in multilevel inverter fed drives, in 2014 IEEE 6th India International Conference on Power Electronics, Kurukshetra, India, 1-5.

Agamy, M. S., Harfman-Todorovic, M., Elasser, A. 2013. Ground fault and insulation degradation detection and localization in PV plants, in 2013 IEEE 39th Photovoltaic Specialists Conference, Tampa, FL, USA, 2840-2844.

Alluhaybi, K., Batarseh, I., Hu, H. 2020. Comprehensive Review and Comparison of Single-Phase Grid-Tied Photovoltaic Microinverters, in IEEE Journal of Emerging and Selected Topics in Power Electronics, vol. 8, no. 2, pp. 1310-1329, doi: 10.1109/JESTPE.2019.2900413. 
Al-Saleh, M.A., Mir, M. 1999. A modified univariate search algorithm, in 1999 IEEE International Symposium on Circuits and Systems, Orlando, USA, ISBN: 0-7803-54710, DOI: 10.1109/ISCAS.1999.780156

Amirahmadi, A., et al. 2014. High Efficiency Dual-Mode Current Modulation Method for Low-Power DC/AC Inverters, IEEE Transactions on Power Electronics 29(6): $2638-2642$.

Anku, N., Abayatcye, J., Oguah, S. 2013. Smart grid: An assessment of opportunities and challenges in its deployment in the ghana power system, in 2013 IEEE PES Innovative Smart Grid Technologies Conference, Washington, DC, USA 1-5.

Azani, H., Massoud, A., Benbrahim, L., Williams, B. W., Holiday, D, 2014. An LCL filter-based grid-interfaced three-phase voltage source inverter: performance evaluation and stability analysis, in 2014 Power Electronics Machines and Drives Conference (PEMD), pp. 1-6

Azli, N. A., Salam, Z., Jusoh, A.; et al. 2008. MPPT performance of a grid-connected PV inverter under Malaysian conditions, in 2008 IEEE 2nd International Power and Energy Conference, Johor Bahru, Malaysia, 457-459.

Bayhan, S., Seyedalipour, S. S., Komurcugil, H., Abu-Rub, H. 2019. Lyapunov Energy Function Based Control Method for Three-Phase UPS Inverters With Output Voltage Feedback Loops, in IEEE Access, vol. 7, pp. 113699-113711, DOI: 10.1109/ACCESS.2019.2934404

Bal, S., Rathore, A. K., Srinivasan, D. 2016. Naturally Clamped Snubberless SoftSwitching Bidirectional Current-Fed Three-Phase Push-Pull DC/DC Converter for DC Microgrid Application, IEEE Transactions on Industry Applications 52(2): 1577-1587.

Bao, C., Ruan, X., Wang, X., Li, W., Pan, D., Weng, K. 2014. Step-by-Step Controller Design for LCL- Type Grid-Connected Inverter with Capacitor Current-Feedback Active-Damping, in IEEE Trans. Power Electron., vol. 29, no. 3, pp. 1239-1253

Bastidas-Rodríguez, J. D., et al. 2015. Model-Based Degradation Analysis of Photovoltaic Modules Through Series Resistance Estimation, IEEE Transactions on Industrial Electronics 62(11): 7256-7265.

Bhattacharjee, A. K., Batarseh, I. 2020. Sinusoidally Modulated AC-Link Microinverter Based on Dual-Active-Bridge Topology, in IEEE Transactions on Industry Applications, vol. 56, no. 1, pp. 422-435, Jan.-Feb, doi: 10.1109/TIA.2019.2943119.

Bleizgys, V. 2012. Erdvinio vektoriaus moduliavimo principu valdomo inverterio tyrimas ir taikymas: daktaro disertacija. Vilnius: Technika, 103 p. 978-609-457-142-8.

Bode, G.H., Loh, P. C., Newman, M.J., Holmes, D.G. 2005. An improved robust predictive current regulation algorithm, in IEEE Transactions on Industry Applications, vol. 41, no. 6, pp. 1720-1733, DOI: 10.1109/TIA.2005.858324 
Bodur, H.; et al. 2018. An improved duty cycle ZVT two swicth forward converter, in 2018 5th International Conference on Electrical and Electronic Engineering, Istanbul, Turkey, 36-40.

Bulut, Ö., Aydemir, M. T. 2018. Design and loss analysis of a 200-W GaN based active clamp forward converter, in 2018 5th International Conference on Electrical and Electronic Engineering (ICEEE), Istanbul, Turkey, 97-100.

Caiza, D. L., Kouro, S., Flores-Bahamonde, F., Hernandez, R. 2018. Unfolding PV Microinverter Current Control: Rectified Sinusoidal vs Sinusoidal Reference Waveform, in 2018 IEEE Energy Conversion Congress and Exposition, USA, ISBN: 978-1-47997312-5, DOI: 10.1109/ECCE.2018.8558024

Capitaine, A., et al. 2016. Loss analysis of flyback in discontinuous conduction mode for sub-mW harvesting systems, in 2016 14th IEEE International New Circuits and Systems Conference, Vancouver, BC, Canada, 1-4.

Causo, A., et al. 2013. Power losses analysis in interleaved flyback based PV grid connected micro-inverters, in Industrial Electronics Society, IECON 2013 - 39th Annual Conference of the IEEE. Vienna, 1833-1838.

Cha, W., et al. 2015. Highly Efficient Microinverter With Soft-Switching Step-Up Converter and Single-Switch-Modulation Inverter, IEEE Transactions on Industrial Electronics 62(6): 3516-3523.

Chang-liang, L., Hui-chao, Z. 2014. Photovoltaic Grid-connected Micro-inverter Based on Self-tuning Fuzzy-PI Controller, in Advanced Materials Research, vol. 986, pp. 1098-1102

Chen, H., et al. 2018. Determining the Number of Transformer Shielding Winding Turns for Suppressing Common-Mode Noise in Flyback Converters, IEEE Transactions on Electromagnetic Compatibility 60(5): 1606-1609.

Chen, W., et al. 2009. PCB Winding Loss Model and Design for Push-pull Transformer, in 2009 Twenty-Fourth Annual IEEE Applied Power Electronics Conference and Exposition, Washington, DC, USA, 1018-1021.

Chowdhury, A. S. K., et al. 2013. Design And Implementation Of A Highly Efficient Pure Sine-Wave Inverter For Photovoltaic Applications, in 2013 International Conference on Informatics, Electronics and Vision, Dhaka, Bangladesh, 1-6.

Chowdhury, A. S. K., et al. 2014. Single-phase grid-tie photovoltaic inverter using maximum power point tracking with flyback converter, in 2014 3rd International Conference on the Developments in Renewable Energy Technology, Dhaka, Bangladesh, 1-6.

Cui, H., et al. 2008. Current harmonics reduction of square wave inverter by using adjustable filter for high speed motor power supply, in 2008 International Conference on Electrical Machines and Systems, Wuhan, China 954-957. 
Dash, P. P., Kazerani, M. 2011. Dynamic Modeling and Performance Analysis of a GridConnected Current-Source Inverter-Based Photovoltaic System, in IEEE Transactions on Sustainable Energy, vol. 2, no. 4, pp. 71-75, DOI: 10.1109/TSTE.2011.2149551

Dong, Y., et al. 2015. Invsetigation of PV inverter MPPT efficiency test platform, in International Conference on Renewable Power Generation, Beijing, China, 1-4.

Edwin, F. F., et al. 2014. Dynamic Modeling and Control of Interleaved Flyback Module-Integrated Converter for PV Power Applications, IEEE Trans. on Ind. Elec., 61: 1377-1388.

Erickson, R. W., Rogers, A. P. 2016. A microinverter for building-integrated photovoltaics, in Proc. IEEE Appl. Power Electron. Conf. Expo., Washington, DC, USA.911-917, 2012.

Feng, J., et al. 2018. A Three-Phase Grid-Connected Microinverter for AC Photovoltaic Module Applications, IEEE Transactions on Power Electronics 33(9): 7721-7732.

Fermin, A., et al. 2015. Power losses calculations in windings of gapped magnetic components: The i2D method applied to flyback transformers, in 2015 IEEE Energy Conversion Congress and Exposition, Montreal, QC, Canada, 5675-5681.

Firdaus, A., Mishra, S. 2018. A double derivative based droop controller for improved power sharing in inverter based autonomous microgrid, in 2018 IEEMA Engineer Infinite Conference, New Delhi, India, 1-6.

Gagrica, O., et al. 2015. Microinverter Curtailment Strategy for Increasing Photovoltaic Penetration in Low-Voltage Networks, IEEE Transactions on Sustainable Energy 6(2): 369-379.

Gazoli, J. R., Villalva, M. G., Ruppert, E. 2012. Micro-inverter for integrated grid-tie photovoltaic module using resonant controller, in 2012 IEEE Power and Energy Society General Meeting, San Diego, USA, ISBN: 978-1-4673-2729-9, DOI:10.1109/PESGM.2012.6344911

Golembiovskiy, U., M., Lukov, U. Y., Tomashevskiy, Y. B. 2018. Features of the DC Mikrogrid Realization, in 2018 International Conference on Actual Problems of Electron Devices Engineering, Saratov, Russia, 310-316.

$\mathrm{Gu}, \mathrm{B}$, et al. 2013. High reliability and efficiency single-phase transformerless inverter for grid-connected photovoltaic systems, IEEE Trans. Power Electron., 28(5): 22352244.

Gulame, M. B., et al. 2018. Design Of Solar Based Pure Sine Wave Inverter, in 2018 Second International Conference on Computing Methodologies and Communication, Erode, India, 924-927.

Haider, R., et al. 2012. Design and construction of single phase pure sine wave inverter for photovoltaic application, in 2012 International Conference on Informatics, Electronics \& Vision, Dhaka, Bangladesh, 190-194. 
Haji, D., Genc, N. 2018. Fuzzy and P\&O Based MPPT Controllers under Different Conditions, in 2018 7th International Conference on Renewable Energy Research and Applications, Paris, France, 649-655.

Halder, T. 2018. Power Loss Modeling of the Semiconductors Using the Flyback Converters, in 2018 8th IEEE India International Conference on Power Electronics, Jaipur, India, 1-6.

Hansen, J., et al. 2016. Ice Melt, Sea Level Rise And Superstorms: Evidence From Paleoclimate Data, Climate Modeling, And Modern Observations That $2{ }^{\circ} \mathrm{C}$ Global Warming Could Be Dangerous, Atmospheric Chemistry and Physics 16(6): 3761-3812.

Hasan, R., Mekhilef, S., Nakaoka, M., Nishida, K. 2016. Soft-switching active-clamp flyback microinverter for PV applications, in 2016 IEEE 2nd Annual Southern Power Electronics Conference (SPEC), Auckland, pp. 1-6

Hassan, M.A, Abido, M. A., 2011. Optimal Design of Microgrids in Autonomous and Grid-Connected Modes Using Particle Swarm Optimization,in IEEE Transactions on Power Electronics, vol. 26, no. 3, pp. 755-769, DOI: 10.1109/TPEL.2010.2100101

Hlali, Mo., Bahri, I., Belloumi, H., Kourda, F. 2019. Comparative analysis of PI and PR based Current Controllers for Grid Connected Photovoltaic Micro-inverters, in 2019 10th International Renewable Energy Congress, Sousse, Tunisia, ISBN: 978-1-72810140-8, DOI: 10.1109/IREC.2019.8754522

Holguin F., Prieto R., Asensi R. 2015. Power losses calculations in windings of gapped magnetic components: The i2D method applied to flyback transformers, in 2015 IEEE En-ergy Conversion Congress and Exposition

Hu, H., et al. 2013. A Review of Power Decoupling Techniques for Microinverters With Three Different Decoupling Capacitor Locations in PV Systems, IEEE Transactions on Power Electronics 28(6): 2711-2726.

Hu, H., Harb, S., Kutkut, N. H., Shen, Z. J., I. Batarseh, I. 2013. A Single-Stage Microinverter Without Using Eletrolytic Capacitors, in IEEE Transactions on Power Electronics, vol. 28, no. 6, pp. 2677-2687, June

Huber, L., et al. 2018. Flyback converter with hybrid clamp, in 2018 IEEE Applied Power Electronics Conference and Exposition, San Antonio, TX, USA, 2098-2103.

Yan, T., et al. 2014. Variable-on-time-controlled critical-conduction-mode flyback PFC converter, IEEE Trans. Ind. Electron., 61( 11): 6091-6099.

Yang, J., Do, H. 2018. Efficient Single-Switch Boost-Dual-Input Flyback PFC Converter With Reduced Switching Loss, IEEE Transactions on Industrial Electronics 62(12): 7460-7468.

Yongjun, L., Shun, W., Jing, L., Chen, C., Weiliang, L. 2017. Grid-connected current control of micro inverter based on ANN inverse model, in 2017 29th Chinese Control And Decision Conference, China, ISBN: 978-1-5090-4657-7, DOI: 10.1109/ECCE.2018.8558024 
Jaballah, M. A., et al. 2015. Development of a MPPT controller for hybrid wind/photovoltaic system based on SOPC and NIOS II, in 2015 16th International Conference on Sciences and Techniques of Automatic Control and Computer Engineering, Monastir, Tunisia, 700-706.

Jäger-Waldau, A., et al. 2018. Photovoltaics in Europe after the Paris Agreement, in 2018 IEEE 7th World Conference on Photovoltaic Energy Conversion, Waikoloa Village, HI, USA, 3835-3837.

Jayalath, S., Hanif, M. 2015. Controller tuning for a single phase grid-connected current source inverter, in 2015 IEEE 2nd International Future Energy Electronics Conference, Taipei, Taiwan, ISBN: 978-1-4799-7657-7, DOI: 10.1109/IFEEC.2015.7361586

Jang, S. R., Ryoo, H. J., Goussev, G., Rim, G. H. 2012. Comparative Study of MOSFET and IGBT for High Repetitive Pulsed Power Modulators, in IEEE Trans. Plasma Sci., vol. 40, no. 10, pp. 2561-2568

Jiang, S., et al. 2012. Grid-Connected Boost-Half-Bridge Photovoltaic Microinverter System Using Repetitive Current Control and Maximum Power Point Tracking, IEEE Transactions on Power Electronics 27(11): 4711-4722.

Jianqiang, W. et al. 2009. Interleaved push-pull converter with very low input and high output. Power Electronics and Intelligent Transportation System (PEITS), 20092 nd International Conference on. Shenzhen, 247-249.

Jin, X., Zhang, Y., Wang, X. 2012. Strategy and coordinated development of strong and smart grid, in IEEE PES Innovative Smart Grid Technologies, Tianjin, China, 1-4.

Junior, L. G., Tatibana, G.S., Pinto, J.O.P. 2005. A Novel Simple Three Level Push-Pull Inverter Suitable for Renewable Energy Based Distributed Generation Systems Applications, in 2005 IEEE 36th Power Electronics Specialists Conference, Recife, Brazil, 829-834.

Kamil, M. 2019 Grid-Connected Solar Microinverter Reference Design Using a dsPIC Digital Signal Controller,". Available online: http://ww1.microchip.com/downloads/en/appnotes/pv_appnotes.pdf (09-12-2019).

Kazmierkowski, M.P., Malesani, L., 1998. Current control techniques for three-phase voltage-source PWM converters: a survey, in IEEE Transactions on Industrial Electronics, vol. 45, no. 5, pp. 691-703, DOI: 10.1109/41.720325

Keogh, B.,Cohen, I. 2016. Flyback transformer design considerations for efficiency and EMI. Texas instruments, p. 37.

Khalilian, M., et al. 2015. New single-stage soft-switching flyback inverter for AC module application with simple circuit, in The 6th Power Electronics, Drive Systems \& Technologies Conference, Tehran, Iran, 41-46.

Kharitonov, S. A., Shtein, D. A. 2012. Comparison of the inverter schemes in an autonomous power supply system, in International Conference and Seminar of Young 
Specialists on Micro/Nanotechnologies and Electron Devices, Erlagol, Altai, Russia, 354-357.

Khluabwannarat, P., et al. 2007. An analysis of iron loss supplied by sinusoidal, square wave, bipolar PWM inverter and unipolar PWM inverter, in 2007 International Power Engineering Conference, Singapore, Singapore, 1185-1190.

Kim, C. E., et al. 2017. Improved three switch-active clamp forward converter with low switching loss, in 2017 IEEE 3rd International Future Energy Electronics Conference and ECCE Asia, Kaohsiung, Taiwan, 275-279.

Kim, H., Yu, T., Choi, S. 2008. Indirect Current Control Algorithm for Utility Interactive Inverters in Distributed Generation Systems, in IEEE Transactions on Power Electronics, vol. 23, no. 3, pp. 1342-1347, DOI: 10.1109/TPEL.2008.920879

Ko, J., Chung, D. 2016. The MPPT control of PV system using the series-connected PI controller, in 2016 16th International Conference on Control, Automation and Systems, Gyeongju, South Korea, 807-809.

Kojabadi, H. M., Yu, B., Gadoura, I. A., Chang, L., Ghribi, M. 2006. A novel DSPbased current-controlled PWM strategy for single phase grid connected inverters, in IEEE Transactions on Power Electronics, vol. 21, no. 4, pp. 985-993, DOI: 10.1109/TPEL.2006.876851

Lai, C. M., et al. 2014. Parallel-operated single-stage flyback-type single-phase solar micro-inverter, in 2014 International Conference on Intelligent Green Building and Smart Grid, Taipei, Taiwan, 1-5.

Lai, C., Yang, M., Liu, W. 2014. Parallel-operated single-stage flyback-type singlephase solar micro-inverter, in 2014 International Conference on Intelligent Green Building and Smart Grid (IGBSG), Taipei, pp. 1-5, doi: 10.1109/IGBSG.2014.6835248

Lee, J. Y. M. 2016. Variable PID Gain Tuning Method Using Backstepping Control With Time-Delay Estimation and Nonlinear Damping, IEEE Transactions on Industrial Electronics 61(12): 6975-6985.

Lee, T.-L., Hu, S.-H. 2016. An Active Filter With Resonant Current Control to Suppress Harmonic Resonance in a Distribution Power System, in IEEE Journal of Emerging and Selected Topics in Power Electronics, vol. 4, no. 1, pp. 198-209, http://dx.doi.org/10.1109/JESTPE.2015.2478149

Leuenberger D., Biela J. 2015. Accurate and computationally efficient modeling of flyback transformer parasitics and their influence on converter losses, in 2015 17th European Conference on Power Electronics and Applications, Geneva, 1-10.

Li, Q., et al. 2002. Large-signal transient analysis of forward converter with activeclamp reset, IEEE Trans. Power Electron., 17(1): 15-24.

Libin, Y., Xin, Y.; Ming Z.; et al. 2015. A New Theory of Reactive Power Control of Grid Connected PV Inverter, in 2015 International Conference on Intelligent Transportation, Big Data and Smart City, Halong Bay, Vietnam, 35-38. 
Lind, A. 2013. Single Transistor Forward Converter Design. Infineon Technologies Austria AG. 11 p.

Liserre, M., Teodorescu, R., Blaabjerg, F. 2006. Stability of photovoltaic and wind turbine grid-connected inverters for a large set of grid impedance values, in IEEE Transactions on Power Electronics, vol. 21, no. 1, pp. 263-272, DOI: 10.1109/TPEL.2005.861185

Liu, N., et al. 2015. A Charging Strategy for PV-Based Battery Switch Stations Considering Service Availability and Self-Consumption of PV Energy, IEEE Transactions on Industrial Electronics 62(8):4878-4889.

Liu, J., et al. 2015. Fast prediction for conducted EMI in flyback converters, 2015 IEEE International Conference on Computational Electromagnetics, Hong Kong, China, 247249.

Lopez, D., et al. 2017. Double voltage step-up photovoltaic microinverter, in 2017 IEEE International Conference on Industrial Technology, Toronto, ON, Canada 406-411.

Lopez-Santos, O., García, G., Martinez-Salamero, L. 2015. Derivation of a global model of a two-stage photovoltaic microinverter using sliding-mode control, in IEEE 13th Brazilian Power Electronics Conference and 1st Southern Power Electronics Conference (COBEP/SPEC), Fortaleza, pp. 1-6, doi: 10.1109/COBEP.2015.7420176

Macedo, G. B., Martins, D. C. Coelho, R. F. 2016. Design and comparative analysis of CL CLCL and trap-CL filters for current source inverters, in 2016 IEEE Industry Applications Conference (INDUSCON), pp. 1-8

Melo, F. C.; et al. 2018. Proposal of a Photovoltaic AC-Module With a Single-Stage Transformerless Grid-Connected Boost Microinverter, IEEE Transactions on Industrial Electronics 65(3): 2289-2301.

Melo, F.o C., Garcia, L. S., de Freitas, L. C., Coelho, E. A. A. 2017. Proposal of a Photovoltaic AC-Module With a Single-Stage Transformerless Grid-Connected Boost Microinverter, in IEEE Transactions on Industrial Electronics, vol. 65, no. 3, pp. 22892301, DOI: 10.1109/TIE.2017.2750611

Meneses, D., et al. 2012. Single-stage grid-connected forward microinverter with constant off-time boundary mode control, in Proc. IEEE Appl. Power Electron. Conf. Expo., Phoenix, AZ, USA, 568-574.

Micro-Inverter $\quad$ Market. 2020. Prieiga per internetą: https://www.marketsandmarkets.com/PressReleases/micro-inverter. Peržiūrèta $2020 \mathrm{~m}$. balandžio $16 \mathrm{~d}$.

Min, G., et al. 2018. Design and Control of Single-Phase Grid-Connected Photovoltaic Microinverter with Reactive Power Support Capability, in 2018 International Power Electronics Conference, Niigata, Japan, 2500-2504. 
Minjie, C., Afridi, K. K., Perreault, D.J. 2013. A multilevel energy buffer and voltage modulator for grid-interfaced micro-inverters, in Energy Conversion Congress and Exposition (ECCE), IEEE. Denver, 3070-3080.

Mohammadi, S., et al. 2015. Interleaved two-switch flyback microinverter for grid-tied photovoltaic applications. IEEE. Tehran, 59-64.

Morales-Caporal, M., et al. 2016. Digital simulation of a predictive current control for photovoltaic system based on the MPPT strategy, in 2016 13th International Conference on Power Electronics, Guanajuato, Mexico, 295-299.

Motta L., Faúndes, N. 2016. Active / passive harmonic filters: Applications, challenges \& trends, in 17th International Conference on Harmonics and Quality of Power (ICHQP), Belo Horizonte, Brazil, ISSN: 2164-0610, https://doi.org/10.1109/ICHQP.2016.7783319

Mukherjee, A., Pahlevaninezhad, M., Moschopoulos, G. 2013. A simple flyback microinverter for solar energy systems with variable frequency controlled ZVS, in 2013 IEEE Energy Conversion Congress and Exposition, Denver, CO, pp. 2026-2031

Na, T., Zhang, Q., Tang, J., Wang, J. 2018. Active power filter for single-phase Quasi-Zsource integrated on-board charger, in 2018 CPSS Transactions on Power Electronics and Applications, vol. 3, no. 3, pp. 197-201, DOI: 10.24295/CPSSTPEA.2018.00019

Nayanasiri, D. R., Vilathgamuwa, D. M. ; Maskell, D. L. 2014. HFL PV micro-inverter with front-end current-fed converter and half-wave cycloconverter, in 2014 International Power Electronics Conference, Hiroshima, Japan, 3598-3603.

Namin, A., et al. 2018. Performance of Inductive Wireless Power Transfer Between Using Pure Sine Wave and Square Wave Inverters, in 2018 IEEE Transportation Electrification Conference and Expo, Asia-Pacifi, Bangkok, Thailand, 1-5.

Nan, W., Shangsheng, L. 2017. Current output control strategy based on current reference feed-forward for H-bridge cascaded inverter, in IECON 2017 - 43rd Annual Conference of the IEEE Industrial Electronics Society, Beijing, China, ISBN: 978-15386-1127-2, https://doi.org/10.1109/IECON.2017.8216173

Nimmi Mahesh, A. 2018. Carrier rotation schemes for equal device conduction periods in Cascaded H-bridge Multilevel Inverter, in 2018 International Conference on Power Energy, Environment and Intelligent Control, Greater Noida, India, 696-701.

Ouyang, Z., Zhang, W. 2015. Calculation of leakage inductance for high-frequency transformers, IEEE Transactions on Power Electronics, 30(10): 5769-5775.

Öztürk, S., Çadırc1, I. 2018. A Generalized and Flexible Control Scheme for Photovoltaic Grid-Tie Microinverters, IEEE Transactions on Industry Applications 54 (1): 505-516

Öztürk, S., Çaditoi, I. 2015. A generalized and flexible control scheme for photovoltaic grid-tie microinverters, in 2015 International Conference on Renewable Energy Research and Applications, Palermo, Italy, 699-703. 
Pan, X., et al. 2016. Novel hybrid modulation based isolated high-frequency bidirectional inverter for microgrid application, in IECON 2016 - 42nd Annual Conference of the IEEE Industrial Electronics Society, Florence, Italy, 3517-3522.

Paridari, K., et al. 2013. A new decentralized voltage control scheme of an autonomous microgrid under unbalanced and nonlinear load conditions, in 2013 IEEE International Conference on Industrial Technology, Cape Town, South Africa, 1812-1817.

Perrin, R., et al. 2016. High-Temperature GaN Active-Clamp Flyback Converter With Resonant Operation Mode, IEEE Journal of Emerging and Selected Topics in Power Electronics, 4(3): 1077-1085.

Pezeshki, H., Wolfs, P. J., Ledwich, G. 2014. Impact of High PV Penetration on Distribution Transformer Insulation Life, IEEE Transactions on Power Delivery 29(3): 1212-1220.

Pikutis, M. 2015. Fotovoltinès elektrinès intelektualaus valdymo kūrimas: daktaro disertacija. Vilnius: Technika, 116 p. 978-609-457-877-9.

Platakis, A. 2014. Fotovoltiniu keitikliu tiekiamos energijos kokybès tyrimas ir gerinimas: daktaro disertacija. Vilnius: Technika, 134 p. 978-609-457-681-2.

Popescu, M., Bitoleanu, A., Preda, A. 2018. A New Design Method of an LCL Filter Applied in Active DC-Traction Substations, in IEEE Transactions on Industry Applications, vol. 55, no. 4, pp. 3497-3507, DOI: 10.1109/TIA.2018.2819968

Pradhan, R., Subudhi, B. 2016. Double Integral Sliding Mode MPPT Control of a Photovoltaic System, IEEE Transactions on Control Systems 24(1): 285-292.

Prager, J., Ziemba, T., Miller, K. E., Picard, J., Hashim, A. 2015. Silicon-carbide (SiC) MOSFET -based full-bridge for pulsed power applications, in 2015 IEEE Pulsed Power Conference (PPC), pp. 1-6

Priyambada, S., Mohanty, P. K. 2015. Performance evaluation of DEPSO algorithm on automatic voltage regulator using conventional PID \& Fuzzy-PID controller, in 2015 International Conference on Energy, Power and Environment: Towards Sustainable Growth, Shillong, India, ISBN: 978-1-4673-6503-1.

Raghavendra, H.S. 2015. The multi-input renewable source inverter with current fed isolated half bridge converter and the H-bridge inverter, in International Conference on Smart Technologies and Management for Computing, Communication, Controls, Energy and Materials, Chennai, India, 514-520.

Rajeev, M., Agarwal,V., 2018. Analysis and Control of a Novel Transformer-Less Microinverter for PV-Grid Interface, in IEEE Journal of Photovoltaics, vol. 8, no. 4, pp. 1110-1118, DOI: 10.1109/JPHOTOV.2018.2825298

Rana A. S., et al. 2018. String level optimisation on grid-tied solar PV systems to reduce partial shading loss, IET Renewable Power Generation 12(2): 143-148. 
Raziei, A., Hallinan, K. P., Brecha, R. J. 2014. Cost optimization with solar and conventional energy production, energy storage, and real time pricing, in ISGT 2014, Washington, DC, USA, 1-4.

Reddy, B. D., et al. 2015. Design, Operation, and Control of S3 Inverter for SinglePhase Microgrid Applications, IEEE Transactions on Industrial Electronics 62(9): 5569-5577.

Ryu, D., et al. 2018. Optimum MPPT Control Period for Actual Insolation Condition, in 2018 IEEE International Telecommunications Energy Conference, Turin, Italy, 1-4.

Ryu, S. H., et al. 2016. Analysis and Design of Modified Half-Bridge Series-Resonant Inverter With DC-Link Neutral-Point-Clamped Cell, IEEE Transactions on Power Electronics 31(3): 2282-2295.

Rodriguez, C. T., Fuente, D. V., Garcera, G. 2011. Reconfigurable Control Scheme for a PV Microinverter Working in Both Grid-Connected and Island Modes, in IEEE Transactions on Industrial Electronics, vol. 60, no. 4, pp. 1582-1595, DOI: 10.1109/TIE.2011.2177615

Sahu, P. K., Shaw, P., Maity, S. 2016. Modeling and control of grid-connected DC/AC converters for single-phase micro-inverter application, in 2015 Annual IEEE India Conference, New Delhi, India, ISBN: 978-1-4673-7399-9, DOI: 10.1109/INDICON.2015.7443537

Samundeeswari, S. V., Gopinath, M. 2017. Open loop and closed loop solar based cascaded h-bridge inverter using fuzzy logic, in 2017 International Conference on Innovations in Green Energy and Healthcare Technologies, Coimbatore, India, 1-4.

Sankar, R., et al. 2017. II. PV system description: Maximum power extraction in PV system using fuzzy logic and dual MPPT control, in 2017 International Conference on Energy, Communication, Data Analytics and Soft Computing, Chennai, India, 37643769.

Saxena, N., Singh, B., Vyas, A. L. 2017. Integration of solar photovoltaic with battery to single-phase grid, IET Generation, Transmission \& Distribution 11(8): 2003-2012.

Schmitz, L., et al. 2017. Design optimization of a high step-Up DC-DC converter for photovoltaic microinverters, in 2017 IEEE International Telecommunications Energy Conference, Broadbeach, QLD, Australia, 432-437.

Schuepbach, E., et al. 2015. Swiss Energy Strategy 2050: Research on photovoltaic electricity production, in 2015 Tenth International Conference on Ecological Vehicles and Renewable Energies, Monte Carlo, Monaco, 1-5.

Seliga, R., et al. 2014. Operation of sine-wave voltage source inverter in hybrid genset based autonomous power system, in 7th IET International Conference on Power Electronics, Machines and Drives, Manchester, UK, 1-5.

Shen, G., Zhu, X., Zhang, J., Xu, . 2010. A New Feedback Method for PR Current Control of LCL-Filter-Based Grid-Connected Inverter, in IEEE Transactions on Industrial Electronics, vol. 57, no. 6, pp. 2033-2041, DOI: 10.1109/TIE.2010.2040552 
Sheng, S., Li, P., Lehman, B. 2013. Parallel operation of digital controlled modified sine wave inverters, in 2013 IEEE Energy Conversion Congress and Exposition, Denver, CO, USA, 3440-3447.

Sher, H. A., et al. 2015. A New Sensorless Hybrid MPPT Algorithm Based on Fractional Short-Circuit Current Measurement and P\&O MPPT, IEEE Transactions on Sustainable Energy 6(4): 1426-1434.

Singh, B., Joshi, N. 2017. Tuning Techniques of PID controller: A review, in International Journal on Emerging Technologies (Special Issue NCETST-2017), vol. 8, no. 1 , pp. 481-485

Sukesh, N., Pahlevaninezhad, M., Jain, P. K. 2014. Analysis and Implementation of a Single-Stage Flyback PV Microinverter With Soft Switching, in IEEE Transactions on Industrial Electronics, vol. 61, no. 4, pp. 1819-1833, April

Sukesh, N., Pahlevaninezhad, M.; Jain, P. K. 2015. Analysis and implementation of a single-stage flyback PV microinverter with soft switching, IEEE Trans. Ind. Electron., 61(4): $1819-1833$.

Sun, J. 2011. Impedance-Based Stability Criterion for Grid-Connected Inverters, IEEE Transactions on Power Electronics 26(11):3075-3078.

Surapaneni, R. K., Rathore, A. K. 2015. A Single-Stage CCM Zeta Microinverter for Solar Photovoltaic AC Module, IEEE Journal of Emerging and Selected Topics in Power Electronics 3(4): 892-900.

Suzuki, K., Wada, K. 2019. Current Control using Pulsed Current Sampling Considering Sampling Points and Sensor Positions for Single-Phase Inverter, in 2019 IEEE Applied Power Electronics Conference and Exposition (APEC), Anaheim, USA, ISBN: 978-15386-8330-9, https://doi.org/10.1109/APEC.2019.8721791

Šály, V., et al. 2015. Electrical characterization of PV modules after three years of operation, in 2015 16th International Scientific Conference on Electric Power Engineering, Kouty nad Desnou, Czech Republic, 484-487.

Tamyurek, B., Kirimer, B. 2015. An Interleaved High-Power Flyback Inverter for Photovoltaic Applications, Power Electronics, IEEE Transactions on 30(6): 3228-3241.

Tan, W., Bair, X. 2012. Application research base on system engineering for analyzing smart grid standards, in IEEE PES Innovative Smart Grid Technologies, Tianjin, China $1-3$.

Thang, T. V., et al. 2014. Analysis and Design of Grid-Connected Photovoltaic Systems With Multiple-Integrated Converters and a Pseudo-DC-Link Inverter, IEEE Trans. on Ind. Elec., 61: 3377-3386.

Timofeeva, O. V. 2010. Autonomous inverter based on single-phase modules, in 2010 International Conference on Actual Problems of Electron Devices Engineering, Saratov, Russia, 419-422. 
Umuhoza, J., Zhang, Y., Zhao, S., Mantooth H. A. 2017. An adaptive control strategy for power balance and the intermittency mitigation in battery-PV energy system at residential DC microgrid level, in 2017 IEEE Applied Power Electronics Conference and Exposition, Tampa, FL, USA, 1341-1345.

Uprety, S., Lee, H. 2017. 22.5 A 93\%-power-efficiency photovoltaic energy harvester with irradiance-aware auto-reconfigurable MPPT scheme achieving $>95 \%$ MPPT efficiency across $650 \mu \mathrm{W}$ to $1 \mathrm{~W}$ and $2.9 \mathrm{~ms}$ FOCV MPPT transient time, in 2017 IEEE International Solid-State Circuits Conference, San Francisco, CA, USA, 378-379.

Vongkoon, P., Liutanakul, P., Wiwatcharagoses, N. 2019. Effective low-cost solution using cascaded connection of two modified notch filters to mitigate the second and third harmonic currents in single-phase dual-stage half-bridge microinverter, in IET Power Electronics, vol. 12, no. 12, pp. 3118-3130, 1610 2019, doi: 10.1049/iet-pel.2018.5638

Wang, P., et al. 2016. Comparative study of PD characteristics for inverter-fed motor insulation under sinusoidal and repetitive square wave voltage conditions, in 2016 IEEE International Conference on High Voltage Engineering and Application, Chengdu, China, 1-4.

Wang, R., Hu, B., Sun, S. 2019. Linear Active Disturbance Rejection Control for DC Side Voltage of Single-Phase Active Power Filters, in IEEE Access, vol. 7, pp. 7309573105, DOI: 10.1109/ACCESS.2019.2920626

Wang, T.H., Lo, Y.K. 2013. A DSP-based Grid-tied Solar Cascade-micra-inverter, in 2013 1st International Future Energy Electronics Conference, Tainan, Taiwan, ISBN: 978-1-4799-0073-2, DOI: 10.1109/IFEEC.2013.6687558

Whitaker, B., Martin, D., Cilio, E. 2015. Extending the operational limits of the pushpull converter with $\mathrm{SiC}$ devices and an active energy recovery clamp circuit, in 2015 IEEE Applied Power Electronics Conference and Exposition, in Charlotte, NC, USA, 2033-2038.

Wilson, P., Mantooth, H. A. 2013. Model-Based Engineering for Complex Electronic Systems, in Publisher: Newnes: Kidlington, UK , pp. 347-367

Woo-Jun, C., et al. 2017. Highly Efficient Microinverter With Soft-Switching Step-Up Converter and Single-Switch-Modulation Inverter. Industrial Electronics, IEEE Transactions 62(6): 3516-3523.

Wu, Q., et al. 2017. A Wide Load Range ZVS Push-Pull DC/DC Converter With Active Clamped, IEEE Transactions on Power Electronics 32(4): 2865-2875.

Wu, Q., et al. 2018. ZVS three-phase current-fed push-pull converter employing a simple active-clamp circuit for voltage step-up applications, IET Power Electronics 11(14): 2286-2294.

Xia, Y., Ayyanar, R. 2017. Naturally Adaptive, Low-Loss Zero-Voltage-Transition Circuit for High-Frequency Full-Bridge Inverters With Hybrid PWM Grid-Tied Inverter, in IEEE Transactions on Power Electronics, vol. 33, no. 6, pp. 4916-4933, http://dx.doi.org/10.1109/TPEL.2017.2734638 
Xiangjun, Z., Hankui, L., Dianguo, H. 2003. Analysis and de-sign of the flyback transformer, in Industrial Electronics Society, 2003. IECON '03. The 29th Annual Conference of the IEEE. Harbin, 715-719.

Xin, Z., Mattavelli, P., Yao, W. 2017. Mitigation of Grid-Current Distortion for LCLFiltered Voltage-Source Inverter With Inverter-Current Feedback Control, in IEEE Transactions on Power Electronics, vol. 33, no. 7, pp. 6248-6261, doi:10.1109/TPEL.2017.2740946

Xin, Z., Mattavelli, P., Yao, W., 2017. Mitigation of Grid-Current Distortion for LCLFiltered Voltage-Source Inverter With Inverter-Current Feedback Control, in IEEE Transactions on Power Electronics, vol. 33, no. 7, pp. 6248-6261, DOI: 10.1109/TPEL.2017.2740946

Xue, Y., et al. 2010. Topologies of single-phase inverters for small distributed power generators: An overview, IEEE Trans. Power Electron., 19(5): 1305-1314.

Xue, L., Zhang, J. 2018. Highly Efficient Secondary-Resonant Active Clamp Flyback Converter, IEEE Transactions on Industrial Electronics 65(2): 1235-1243.

Zha, Z., Yang, J., Li, S. 2017. Continuous Output Feedback TSM Control for Uncertain Systems With a DC-AC Inverter Example, in IEEE Transactions on Circuits and Systems II: Express Briefs, vol. 65, no. 1, pp. 71-75, DOI: 10.1109/TCSII.2017.2692256

Zhang, L., et al. 2016. A Family of Five-Level Dual-Buck Full-Bridge Inverters for Grid-Tied Applications, IEEE Transactions on Power Electronics 31(10): 7029-7042.

Zhang, N., Tang, H., Yao, C. 2014. A Systematic Method for Designing a PR Controller and Active Damping of the LCL Filter for Single-Phase Grid-Connected PV Inverters, in www.mdpi.com/journal/energies, vol. 7, pp. 3934-3954, DOI: 10.3390/en7063934

Zhang, Z., He, X. F., Liu, Y. F. 2013. An Optimal Control Method for Photovoltaic Grid-Tied-Interleaved Flyback Microinverters to Achieve High Efficiency in Wide Load Range, in IEEE Transactions on Power Electronics, vol. 28, no. 11, pp. 5074-5087

Zhang, Z., He, X., Liu, Y. 2013. An Optimal Control Method for Photovoltaic GridTied-Interleaved Flyback Microinverters to Achieve High Efficiency in Wide Load Range, IEEE Transactions on Power Electronics 28(11): 5074-5087.

Zhao, J., Dai, F. 2007. A New Soft-Switching Two-Switch Forward Converter, in 2007 IEEE Power Electronics Specialists Conference, Orlando, FL, USA, 184-188. 


\section{Autoriaus mokslinių publikacijụ disertacijos tema sąrašas}

\section{Straipsniai recenzuojamuose mokslo žurnaluose}

Bielskis, E., Baskys, A., Valiulis, G. 2020. Controller for the Grid-Connected Microinverter Output Current Tracking. Symmetry. 12(1): 1-13. ISSN 2073-8994 (Clarivate Analytics Web of Science).

Bielskis, E., Šapurov, M., Valiulis, G., Balbonas, D. 2018. Flyback mikroinverterio sudaryto iš dviejų raktų modelio matlab/simulink aplinkoje sudarymas ir tyrimas. Mokslas - Lietuvos ateitis. 10: 1-6. Vilnius: Technika. ISSN 2029-2341.

Bielskis, E., Baskys, A., Sapurov, M. 2017. Single stage microinverter based on twoswitch DC-DC flyback converter. Electronics and electrical engineering. 23(4): 29-32. Kaunas: Technologija. ISSN 1392-1215 (Clarivate Analytics Web of Science).

Bielskis, E., Baskys, A., Sapurov, M. 2016. Impact of Transformer Design on Flyback Converter Voltage Spikes. Electronics and electrical engineering. 22(5): 58-61. Kaunas: Technologija. 2016 ISSN 1392-1215 (Clarivate Analytics Web of Science).

Bielskis, E., Šapurov, M., Platakis, A. 2016. Elektros tinklo mikroinverterio naudingumo faktoriaus tyrimas. Mokslas - Lietuvos ateitis. 8(3): 296-301. Vilnius: Technika. ISSN 2029-2341. 


\section{Straipsniai kituose leidiniuose}

El Iysaouy, L., Baskys, A., Bielskis, E., Lahbabi, M., Oumnad, A. 2018. Impact of flyback transformer and switch parameters on efficiency of single stage photovoltaic microinverter, 2018 Open Conference of Electrical, Electronic and Information Sciences (eStream). Vilnius, Lithuania, 2018 m. balandis. p. 1-4. ISBN: 978-1-5386-6737-8.

El Iysaouy, L., Baskys, A., Bielskis, E., Oumnad, M., Lahbabi, M. 2018. Impact of CL and LCL Low Pass Output Filters on High Order Harmonics of Single Stage Photovoltaic Microinverter, 2018 International Symposium on Advanced Electrical and Communication Technologies (ISAECT), Rabat, Morocco, 2018 m. spalis. p. 1-5. ISBN: 978-1-5386-7328-7. 


\section{Summary in English}

\section{Introduction}

\section{Formulation of the problem}

The low-power photovoltaic inverters for a single standard photovoltaic module with a maximum power of about $250 \mathrm{~W}$ are increasingly being used. Such inverters are called photovoltaic microinverters. The main advantage of microinverters is that by converting the DC photovoltaic voltage to alternating AC, the maximum power operation mode is guaranteed individually for each photovoltaic module.

However, photovoltaic microinverters have drawbacks. The main drawback is lower energy efficiency compared to inverters designed to serve many photovoltaic modules. The reason for this is that the voltage supplied by the single photovoltaic module is relatively low (about $30 \mathrm{~V}$ ), so a DC/DC converter that has to boost the voltage to the amplitude value of the electrical grid voltage is needed. Because of this, part of the energy is lost in the converter, therefore, the overall efficiency of the microinverter decreases. Another problem is harmonic distortions of the microinverter output current, which generate higher harmonics in the grid.

In summary, the following problems of photovoltaic microinverters, which are solved in the dissertation, can be formulated: the problem of energy efficiency; the problem of harmonic distortions of the output current. 


\section{Relevance of the Thesis}

Market research shows (Micro-Inverter Market 2020) that from 2018, the microinverter market is growing at $19.3 \%$ annually and will reach $\$ 5.9$ billion in 2023 . The growth of the market is on the one hand due to the continuous development and research activity that allow to improve constantly the parameters of microinverters and reduce the price, on the other hand, the market is growing rapidly due to the increasing number of newly installed photovoltaic power plants. Therefore, research dedicated to development more advanced microinverters with high efficiency and low harmonic distortions of the output current is relevant and has practical value.

\section{The object of Research}

The object of the research is the energy efficiency of the photovoltaic microinverter and the quality of the current generated into the electrical grid by the microinverter.

\section{The Aim of the Thesis}

The aim of the work is to develop an energy-efficient single-stage photovoltaic microinverter and its controller for control of output current, to investigate the microinverter experimentally and using simulation.

\section{The tasks of the Thesis}

To achieve the aim of the work, the following tasks are solved:

1. To develop an energy-efficient DC-DC voltage converter and on the basis of it to create a single-stage photovoltaic microinverter and to investigate it using simulation and experimentally.

2. To develop a control algorithm and controller for feedback control of the microinverter output current supplied to the electrical grid, to investigate the control system using simulation and experimentally.

3. To investigate the influence of the component parameters on the microinverter efficiency using simulation and experimentally.

\section{Research Methodology}

Analytical methods, simulation and experimental investigation are applied in the work.

\section{Scientific Novelty of the Thesis}

1. A new two switch flyback DC-DC converter has been developed for a single-stage microinverter, which has a higher efficiency as compared to another DC-DC converters used for the same purpose.

2. A new PI control algorithm with a time-varying proportional constant for microinverter output current control, which allows us to decrease harmonic distortions of the microinverter output current compared to the case when popular PI controller is used, has been developed. 
3. A new "chessboard" method of arranging the windings of the microinverter flyback transformer, which allows to provide lower voltage spikes in the primary transformer coil compared to other known winding arrangements, has been proposed.

\section{Practical Value of the Research Findings}

The obtained research results can be applied to the development of energy efficient photovoltaic microinverters.

\section{Defended statements}

1. The efficiency of the developed two switches DC-DC voltage flyback converter reaches 0.918 at $80 \mathrm{~W}$ load power and $36 \mathrm{kHz}$ switching frequency. The obtained efficiency is $2.3 \%$ higher compared to the efficiency of the DC-DC voltage flyback converter based on the classical topology.

2. By controlling the output current of the microinverter supplied to the electrical grid using a PI controller with a time-varying proportional constant, the harmonic distortions of the current in the case when electrical grid voltage is not distorted by higher harmonics are reduced by $42 \%$ and if the electrical grid voltage is distorted by the 3rd and 5th harmonics - by $21.7 \%$, compared to results obtained using a conventional PI controller.

3. The influence of the active resistance of the primary winding of the flyback transformer on the efficiency of the microinverter is 40 times, and impact of the resistance of the open transistor of the switches used for commutation of this winding is 33 times higher than the influence of the same parameters of the secondary winding and the transistors of switches used in it.

4. The arranging of windings of the flyback transformer with the proposed "chessboard" method allows to reduce the power loss in the overvoltage suppression circuit introduced by the voltage spikes at least by $4.2 \%$, compared to other known methods of arranging the windings when the power supplied to the load is $100 \mathrm{~W}$.

\section{Approval of the Research Findings}

7 scientific articles have been published on the topic of the dissertation: 5 in peerreviewed scientific journals and 2 in conference proceedings.

\section{Structure of the Dissertation}

The dissertation consists of an introduction, three chapters, general conclusions, lists of references and author's publications on the subject of dissertation, summary in English.

The total scope of dissertation - 119 pages, 15 numbered formulas, 65 pictures, 8 tables, and 167 references. 


\section{Analysis of photovoltaic inverters}

Photovoltaic cells generate a DC voltage, while electrical appliances are designed to be supplied with AC voltage. Therefore, the energy of photovoltaic modules, which are composed of many photovoltaic cells, cannot be used directly (Surapaneni et al. 2015; Feng et al. 2018; Jiang et al. 2012; Melo et al. 2018; Öztürk et al. 2018; Zhang 2013 ). In order to use photovoltaic energy, it is necessary to convert a DC voltage to AC one (Gagrica et al. 2015; Hu et al. 2013.). To achieve this goal, a power electronics device an inverter is needed (Bleizgys 2012; Platakis 2014). It converts a DC photovoltaic voltage to AC. There are two groups of photovoltaic inverters: off-grid and grid-tied inverters. Off-grid inverters (Kharitonov et al. 2012; Firdaus et al. 2018; Seliga et al. 2014) that generate electricity on an energy island disconnected from the centralized electricity supply network. Grid-tied inverters (Sun 2011; Azli 2008; Libin 2015) that supply electricity to the centralized electrical grid.

There are several types of grid-tied inverters as central inverter, series inverter, multi-series inverter where one inverter serves many photovoltaic modules, which usually are connected in series. Because the parameters of photovoltaic modules have dispersions and the modules can operate under different conditions, their individual maximum power regime is different, so the maximum possible energy will not be generated in the photovoltaic power plant using these mentioned above inverters.

The microinverter is another type of photovoltaic inverter developed for single standard photovoltaic module with about $250 \mathrm{~W}$ maximum power. The main advantage of such a solution is that each photovoltaic module has its own inverter, so that the maximum power can be drawn from the module. (Öztürk et al. 2015). Such systems also have drawbacks - since single photovoltaic module provides just about $30 \mathrm{~V}$ output voltage, the grid-tied microinverter requires a DC/DC converter that has to boost the voltage to the electrical grid voltage amplitude value. The DC/DC converter causes in additional energy losses (Cha et al. 2015), therefore the efficiency of microinverter is lower as compared to the inverters developed to serve many photovoltaic modules. Because of this, the development of DC/DC boost converters with high efficiency for microinverters is relevant issue.

A photovoltaic grid-tied microinverter usually consists of two main functional units: a DC-DC converter and an inverter. The DC-DC converter raises the relatively low DC voltage of a tens of volts of the photovoltaic module to a value close to the value of the AC voltage amplitude of the electrical grid to which the power is supplied. An inverter using Pulse Width Modulation (PWM) technique provides sinusoidal voltage that has to be synchronized with the electrical grid.

There are single (Lai et al. 2014) and two (Lopez-Santos et al. 2015) stages microinverters:

1. The specificity of single-stage microinverters (Fig. S1.1.) is that the the DC-DC converter not just boosts the voltage using PWM technique but provides the voltage in the shape of sinusoidal half-cycles with the amplitude close to the amplitude of the electrical grid voltage. The inverter converts sinusoidal half-periods into sinusoidal voltage. A single-stage microinverter consists of a relatively small number of electronic 
components that emit power losses, so this type of microinverter has high energy efficiency (Lai et al. 2014). Such a microinverters are usually used to form a single-phase voltage.

2. In a two-stage microinverter, the alternating voltage is generated in two stages (Fig. S1.2.). In the first stage, the voltage of the photovoltaic module is raised by a DC/DC converter to a value close to the amplitude of the electrical grid voltage. In the second stage, the DC voltage is converted to a variable by an inverter using the sinus PWM technique (Vongkoon et al. 2019).

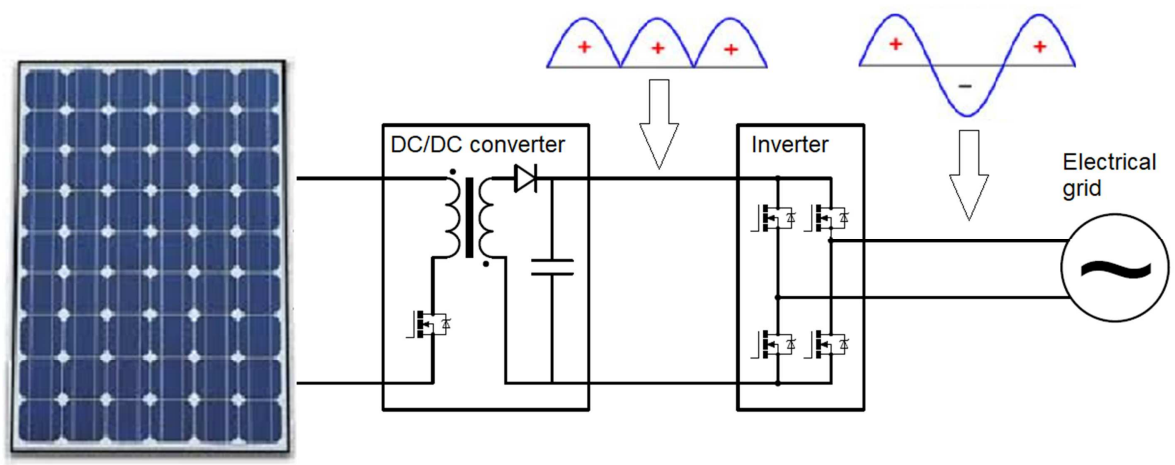

Fig. S1.1. Single stage Microinverter

The flyback DC-DC converters are often used in a single stage photovoltaic microinverters. These converters include a specific transformer with an air gap in ferrite core, which is called a flyback transformer (Keogh et al. 2016). Flyback DC/DC converters work well in current source mode and are therefore well suited for the realization of grid-tied microinverters. Other converters, such as forward converters, are less suitable in this case because they act as voltage sources. Flyback DC/DC converters are characterized by simplicity, energy efficiency and low cost as well.

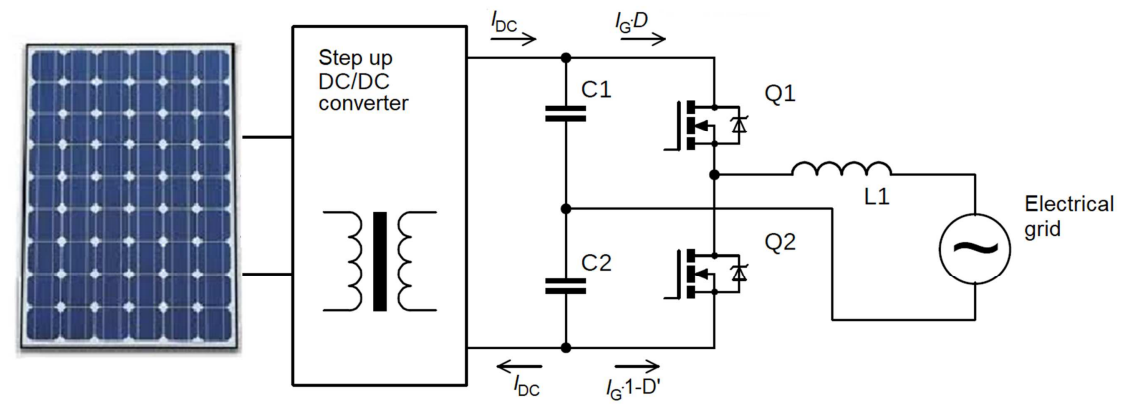

Fig. S1.2. Two stages microinverter 
The quality of energy supplied to the electrical grid by microinverters is becoming an important problem. It is necessary that the microinverters do not contaminate the electrical grid with higher harmonics, i.e. it is necessary that the shape of the current supplied by the microinverter would be as close as possible to the sinus. Therefore, it is important to conduct research and find solutions to reduce nonlinear distortions of the current supplied by the microinverter (Xin et al. 2017; Kojabadi et al. 2006; Nan et al. 2017; Suzuki et al. 2019; Xia et al. 2017).

To reduce current harmonics, it is most effective to use a feedback control system to control the sinusoidal law of the microinverter current. The feedback control system for tracking of sinus reference has to be integrated into the microinverter structure for this purpose. The aim of such a control system is to control the microinverter switches so that the shape of the output current of the microinverter would reproduces the shape and phase of the reference sinusoidal signal (Rajeev et al. 2018; Motta et al. 2016; Xin et al. 2017; Bayhan et al. 2019; Zha et al. 2017). The most popular controllers used for the microinverter output current control are proportional-integral (PI) (Kamil 2019; Hlali et al. 2019) and proportional-integral-differential (PID) (Yongjun et al. 2017; Changliang et al. 2014). The popularity of these well-known controllers is due to the easy implementation and well-developed controller parameters tuning techniques. The disadvantage of PI and PID controllers is that they cannot follow the reference sinusoidal signal without avoiding a steady-state error, therefore, these controllers do not allow to achieve high control accuracy. Because of this, it is relevant to develop a controller with the tuning technique of parameters similar to PI or PID controllers, and at the same time that it would provide higher accuracy of current control.

Based on the analysis made in the overview, the tasks of the work for the development an energy-efficient single-stage photovoltaic microinverter and its controller for control of output current were formulated.

\section{Development and investigation of the power stage of an energy efficient photovoltaic microinverter}

The investigation results of efficiency of a developed DC/DC voltage flyback converter with an alternative active surge suppression circuit and a two-switch DC/DC flyback converter are presented in the second chapter of the dissertation. A new single stage ongrid photovoltaic microinverter based on couple of two-switch DC/DC flyback converters has been proposed. The results presented in this chapter are published in (Bielskis et al. 2018; Bielskis et al 2017; Bielskis et al 2016b)

The developed two-switch DC/DC voltage flyback converter has less electronic components compared to the classic one and is characterized by the simpler control of MOSFET switches. The circuit diagram of the proposed two-switch DC/DC flyback converter is presented in Fig. S2.1.. The spike energy is returned back to the supply source $U_{1}$ using diodes D1 and D2 in this converter. Therefore, the spikes are suppressed by voltage source $U_{1}$ and there is no need to use the reactive components for accumulation of spike energy. The dependences of two-switch DC/DC flyback converter efficiency on output power obtained experimentally are given in Fig. S2.2. The 
efficiency of this converter at $82 \mathrm{~W}$ power and $36 \mathrm{kHz}$ switching frequency is 0.918 , while that of the classic one is 0.895 , i.e. $2.3 \%$ higher.

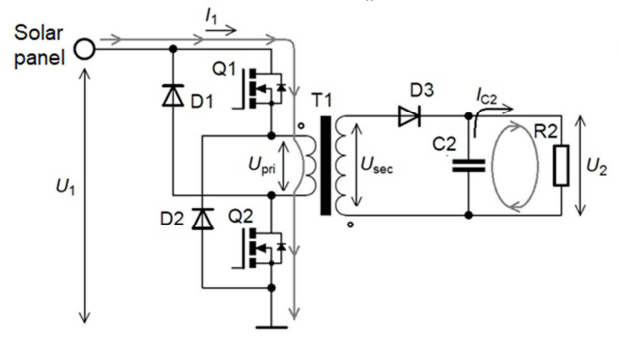

a

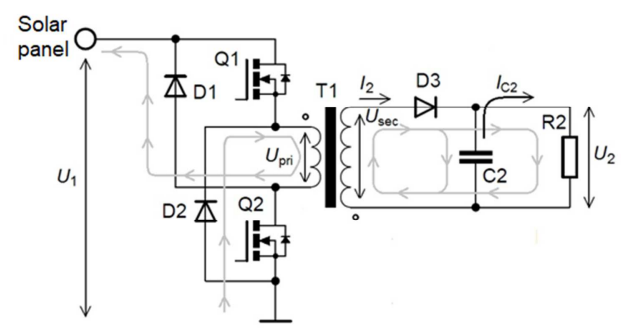

b

Fig. S2.1. Circuit diagram of two-switch DC-DC flyback converter and current flow during the first (a) and second (b) operating cycles

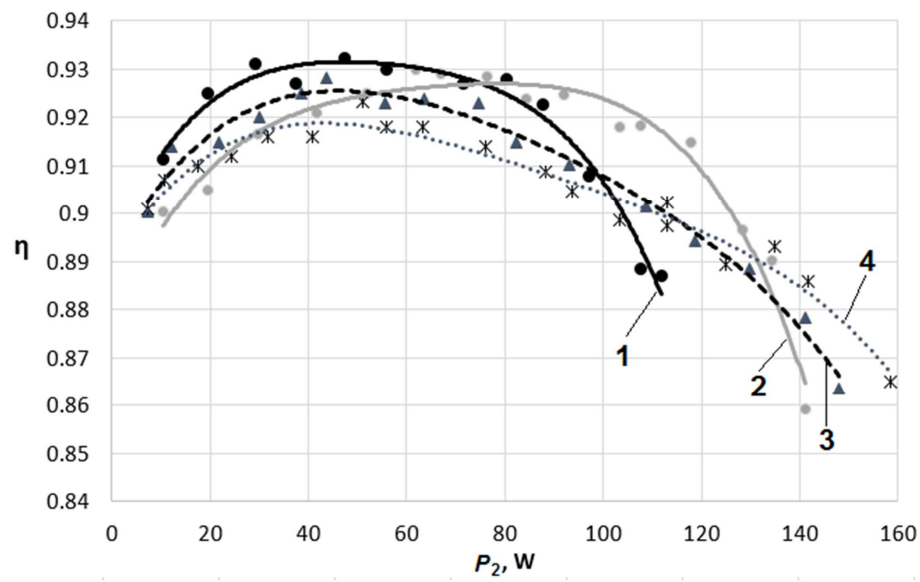

Fig. S2.2. The dependences of two-switch DC-DC flyback converter efficiency on output power at $600 \Omega$ converter load resistance for various switching frequencies: $1-25 \mathrm{kHz} ; 2-36 \mathrm{kHz}$;

$$
3-60 \mathrm{kHz} .4-90 \mathrm{kHz}
$$

The developed single stage photovoltaic microinverter is based on couple of twoswitch DC-DC flyback converters. The circuit diagram of microinverter is presented in Fig. S2.3. Both two-switch DC/DC flyback converters are connected to primary winding of transformer. The couple of two quadrant switches, which are composed of transistors Q5, Q6 and diodes D1, D2, is used in the output of microinverter. The positive half period of output voltage is generated using two-switch DC/DC flyback converter based on transistors Q2 and Q3 (transistors Q1 and Q4 are in state OFF) by applying PWM technique and the output voltage is delivered to load through the diode D1 and transistor Q5, which is in state ON. The negative half period of output voltage is formed similar as positive using two-switch DC/DC flyback converter based on transistors Q1 and Q4 
(transistors Q2 and Q3 are in state OFF) and the output voltage is delivered to load through diode D2 and open transistor Q6. The energy of voltage spikes, which is generated by flyback transformer during the turn off of switch transistor is returned to microinverter supply through the internal diodes of switch transistors Q1- Q4.

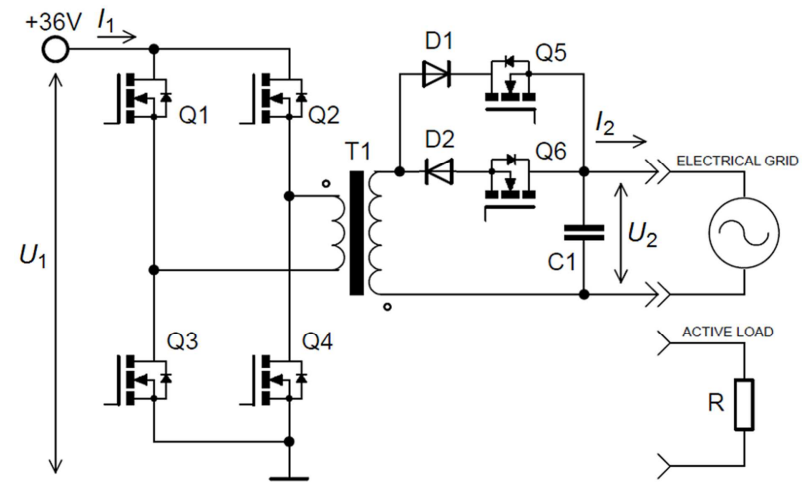

Fig. S2.3. The circuit diagram of single stage microinverter

The single stage microinverter was investigated experimentally and using simulation. The simulation was performed using Matlab/Simulink software. The experimental model of microinverter was designed for experimental investigation. The investigation was performed for two kinds of microinverter load: resistive load (off-grid operation mode); electrical grid load (grid-tied operation mode). The dependences of microinverter efficiency on output power were obtained (Fig. S2.4.). The investigation in off-grid operation mode was performed for the $860 \Omega$ load resistance. The experimentally obtained dependence (Fig. S2.4. curve 1) shows that efficiency reaches 0.95 at $26 \mathrm{~W}$ output power. However, at power higher than $70 \mathrm{~W}$ it drops below 0.9 . The dependence obtained using simulation (Fig. S2.4. curve 3) shows higher efficiency, which reaches 0.96 at $45 \mathrm{~W}$. The simulation error of efficiency in comparison to experimental results is $5 \%$ at $20 \mathrm{~W}$ and reaches $8 \%$ at $100 \mathrm{~W}$. The efficiency of microinverter decreases at higher power because the current of components increases significantly and, as consequence, the power losses in microinverter components rise.

In the case when microinverter operates in grid-tied mode, the experimentally obtained efficiency is higher than 0.9 in range of output power 14 to $72 \mathrm{~W}$ (Fig. S2.4. curve 2). The maximal efficiency value 0.93 is reached at $40 \mathrm{~W}$ output power. The simulation shows (Fig.S2.4. curve 4) higher efficiency, which reaches 0.94 at $35 \mathrm{~W}$. The simulation error of efficiency in respect to experimental results is $2 \%$ at $60 \mathrm{~W}$ and reaches $6 \%$ at $100 \mathrm{~W}$. 


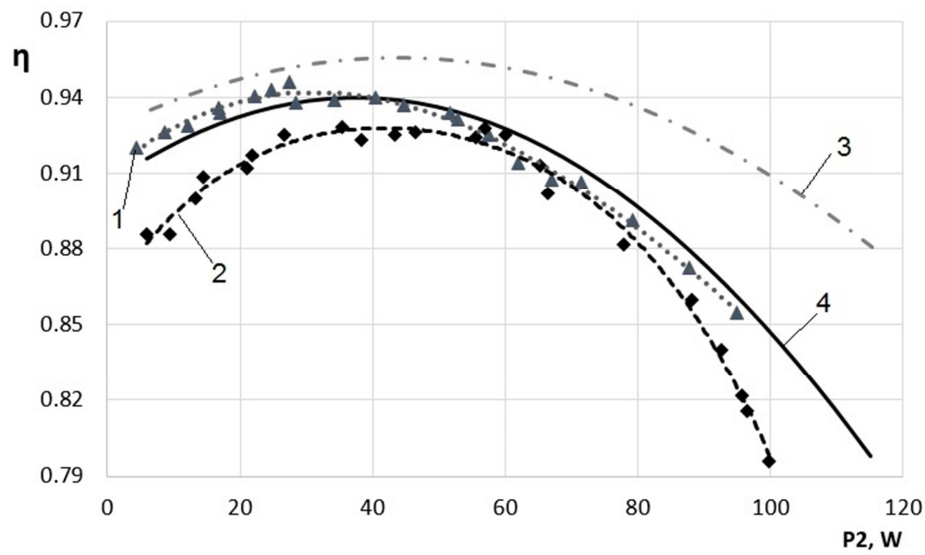

Fig. S2.4. The dependences of single stage microinverter efficiency on output power at $36 \mathrm{kHz}$ switching frequency: 1, 3 - off-grid operation mode, load resistance $860 \Omega ; 2,4$ - grid-tied operation mode. Curves 1 and 2 are obtained experimentally, 3 and 4 - using simulation

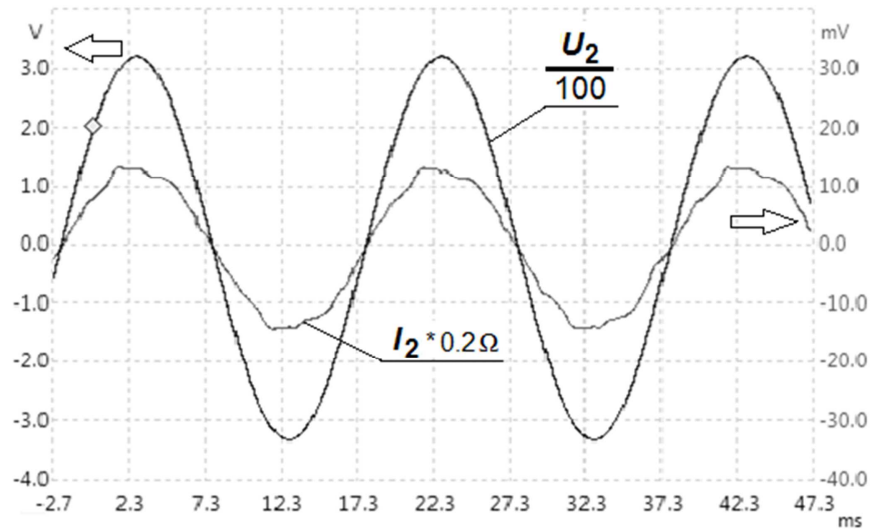

Fig. S2.5. The waveforms of single stage microinverter output voltage and current for the situation when microinverter operates in grid-tied mode at $39 \mathrm{kHz}$ switching

The waveforms of microinverter output voltage and current for the case when microinverter operates in grid-tied mode, i.e. it delivers the current to the grid, were obtained experimentally (Fig. S2.5.). It is seen that the waveform of current is distorted $(\mathrm{THD}=11.2 \%)$. The distortions of grid voltage waveform is negligible. 


\section{Development of a microinverter control system and investigation of the influence of element parameters on the energy efficiency of a microinverter}

In the third chapter a new PI controller with a time-varying proportional constant is proposed and a microinverter output current sinus shape tracking system with a developed controller was investigated. The nonlinear distortions of the current were evaluated. The influence of parameters of the microinverter elements on the microinverter efficiency was investigated. The flyback transformer used in the microinverter has been upgraded. The results presented in this chapter are published in (Bielskis et al. 2020; Iysaouy \& Bielskis et al 2018a; Iysaouy \& Bielskis et al 2018b; Bielskis et al 2016a).

The feedback control system for tracking of the sinusoidal reference has to be used to effectively suppress the higher harmonics of the output current. The purpose of the control system is to form the PWM signals for the control of the microinverter switches in such a way that the shape of the output current of the microinverter would be as close as possible to the sinus. The control algorithm of the suggested controller, which presents the modification of PI controller with the time-varying proportional constant $K_{\mathrm{P}}=K_{\mathrm{V}}(t) K_{\mathrm{C}}$, is as follows:

$$
U(t)=K_{\mathrm{V}}(t) K_{\mathrm{C}} e(t)+K_{\mathrm{I}} \int_{t_{0}}^{t} e(t) \mathrm{d} t,
$$

where $K_{\mathrm{V}}(t)$ and $K_{\mathrm{C}}$ are the time-varying and the constant terms of the proportional constant, respectively. Piecewise linear approximation given in Fig. S3.1. is used for the variation of the $K_{\mathrm{V}}(t)$.

The block diagram of the microinverter control system based on the PI controller with the time-varying proportional constant created using Matlab/Simulink software is presented in Figure S3.2.

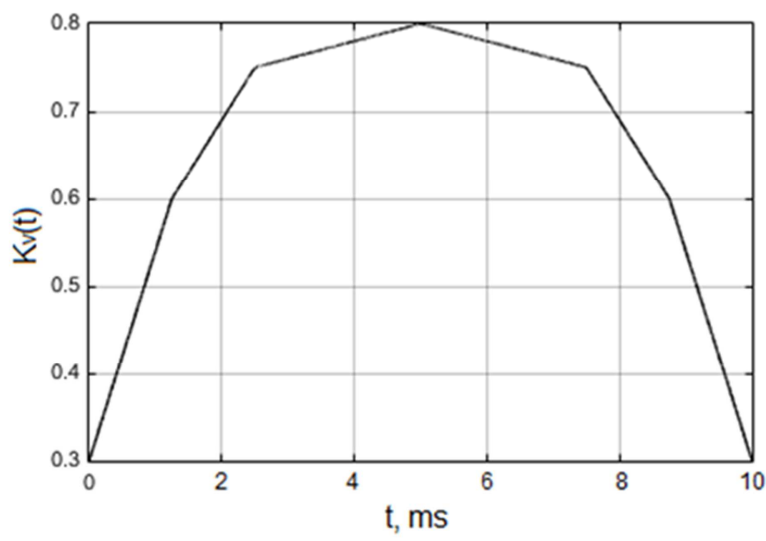

Fig. S3.1. The variation of time-varying constant $K_{\mathrm{V}}(t)$ with time 
The simulation results of microinverter output current using proposed PI controller with the time-varying proportional constant and ordinary PI controller are presented in Fig. S3.3 and Fig. S3.4 respectively. The obtained analysis results show that the employment of the proposed PI controller with the time-varying proportional constant allows us to reduce the high frequency ripples of the output current as compared with the case when the ordinary PI controller is used.

Using the spectra of the current the THD of the microinverter output current was estimated. The THD in the case when PI controller with the time-varying proportional constant is used is $4.4 \%$ at $32 \mathrm{~W}, 3.4 \%$ at $62 \mathrm{~W}$, and $3.3 \%$ at $97 \mathrm{~W}$ load power. The comparison of obtained THD values with these received for the case when the ordinary PI controller is used, shows that the employment of the proposed PI controller allows us to reduce the THD of the microinverter output current by $30 \%$ at $32 \mathrm{~W}$, by $48 \%$ at $62 \mathrm{~W}$, and by $40 \%$ at $97 \mathrm{~W}$ load power.

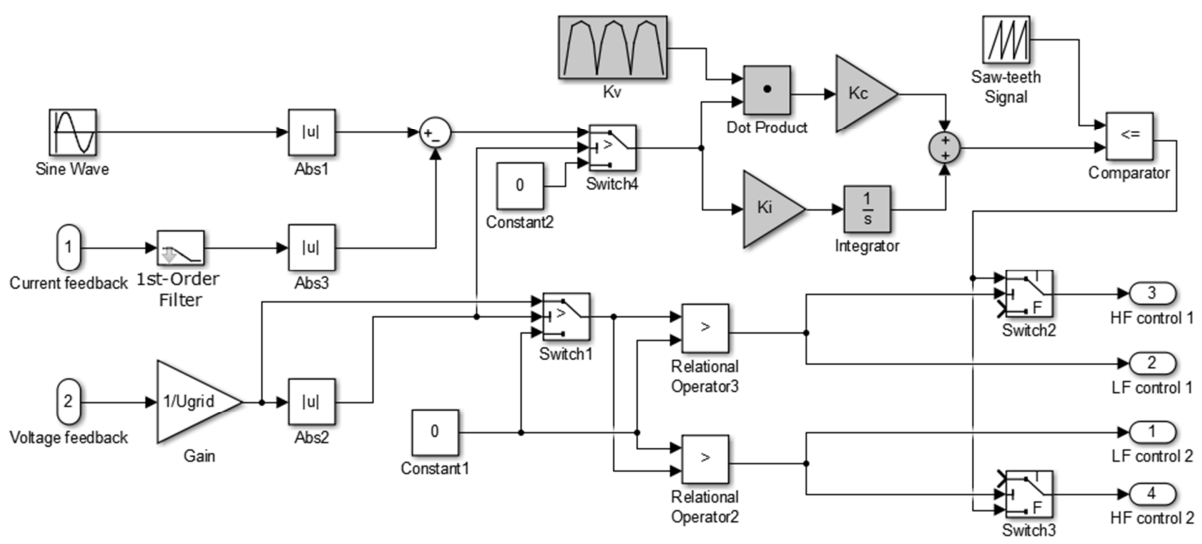

Fig. S3.2. The microinverter control system based on the PI controller with the time-varying proportional constant (the proposed PI controller is depicted with the darker background)

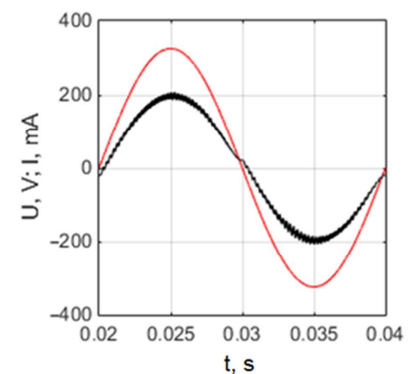

a

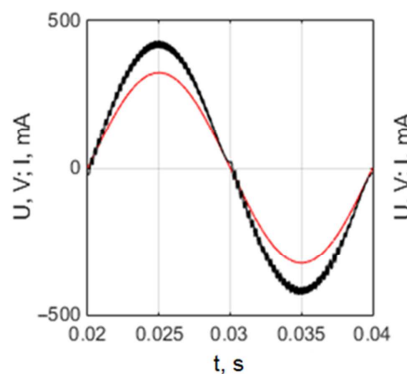

$\mathrm{b}$

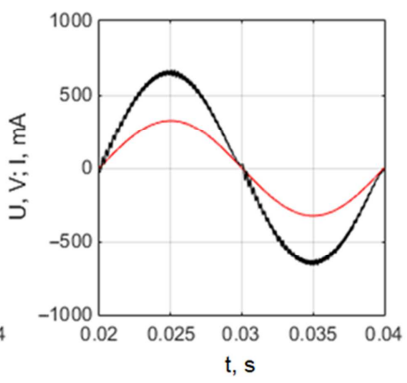

c

Fig. S3.3. The microinverter output current (black curves) when using the PI controller with the time-varying proportional constant at different load power: (a) $32 \mathrm{~W}$, (b) $62 \mathrm{~W}$; (c) $97 \mathrm{~W}$. Red curves represent the electrical grid voltage 


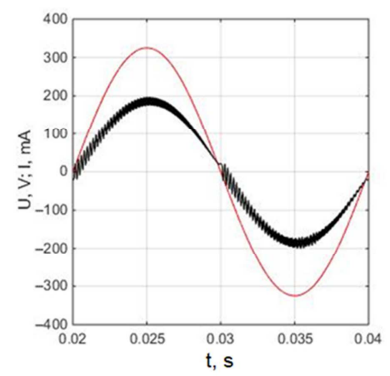

a

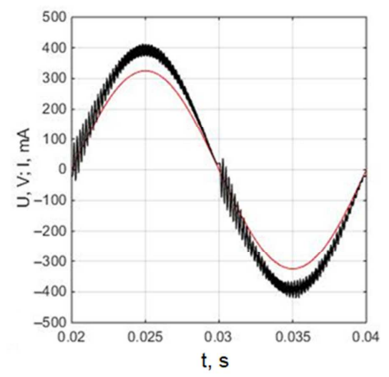

$\mathrm{b}$

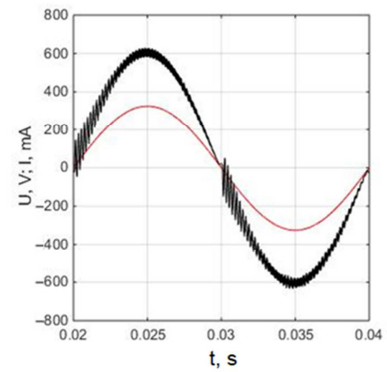

$\mathrm{c}$

Fig. S3.4. The microinverter output current (black curves) when using an ordinary PI controller at different load power: (a) $32 \mathrm{~W}$, (b) $62 \mathrm{~W}$; (c) $97 \mathrm{~W}$. Red curves represent the electrical grid voltage

The impact of parameters of switch transistors and flyback transformer on the microinverter efficiency have been investigated. The results were obtained using Matlab/Simulink software. The microinverter efficiency dependences on the output power at $25 \mathrm{kHz}$ switching frequency at the resistance of MOSFET switch transistors in set $\mathrm{ON}\left(R_{\mathrm{ON}}\right) 0.04 \Omega, 0.08 \Omega$ and $0.12 \Omega$ of the MOSFET switches Q1-Q4 (Fig. S2.3) are presented in the Fig. S3.5. It is seen that the efficiency dependence is monotonous and maximum value 0,98 is reached at the minimal output power, at $R_{\mathrm{ON}}=0.04 \Omega$.

The influence of the flyback transformer primary winding resistance on the microinverter efficiency was investigated. The results obtained at the $25 \mathrm{kHz}$ switching frequency for $0.06 \Omega, 0.12 \Omega$ and $0.24 \Omega$ flyback transformer primary winding resistances are given in Fig. 3.6. It is seen that the decrease of primary winding resistance from $0,24 \Omega$ to $0.06 \Omega$ allows us to increase the efficiency at $100 \mathrm{~W}$ output power from 0.93 to 0.97 , i.e. by $4 \%$. This fact shows that the reduction of flyback transformer primary winding resistance allows us significantly improve the efficiency of single stage photovoltaic microinverter.

The results of investigation of flyback transformer secondary winding resistance impact on the microinverter efficiency show that practically it does not influence the efficiency - it increases just by $0.1 \%$ when the secondary winding resistance decreases from $0,24 \Omega$ to $0.06 \Omega$. Therefore, the diameter of secondary winding wire can be relatively low to save the space for the primary winding, resistance of which should be low to reach high efficiency of the microinverter.

The disadvantage of microinverters based on the flyback DC-DC converters is leakage inductance phenomenon of flyback transformer. It causes increase of voltage spikes generated during the commutation of primary winding. The energy consumed for generation of voltage spikes lowers the efficiency of flyback converter. The experimental investigation of the impact of flyback transformer design on voltage spikes 


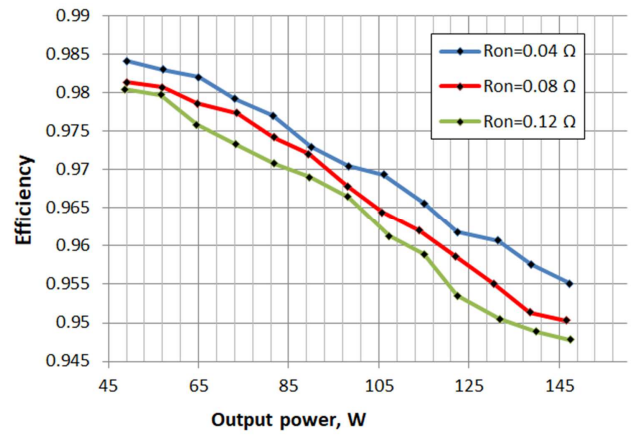

Fig. S3.5. Efficiency dependences of the microinverter with the CL filter on the output power at 25 $\mathrm{kHz}$ switching frequency for various resistances $R_{\mathrm{ON}}$ of the MOSFET switch transistors M1, M2, M3 and M4

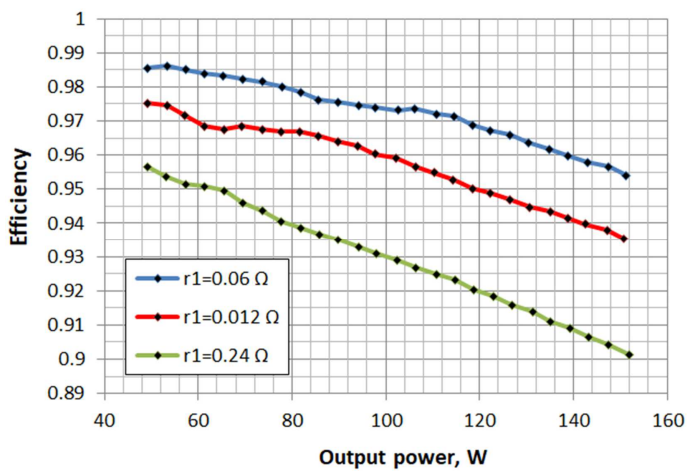

Fig. S3.6. Efficiency dependences of the microinverter with the CL filter on the output power at 25 $\mathrm{kHz}$ switching frequency for various primary winding resistances $r_{1}$ of flyback transformer

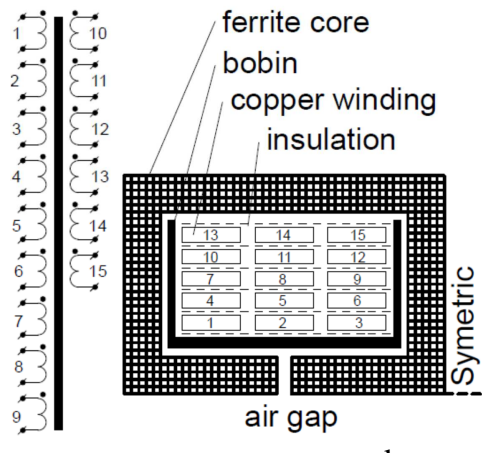

a

b

Fig. S3.7. Design of flyback transformer experimental model: a) circuit diagram of windings; b) windings of the bobbin 
in converter caused by the leakage inductance was performed. The investigation was made for cases when transformer windings are placed using interleaving and sandwich methods and two methods proposed by author. The experimental model of transformer was made using ETD-34 type ferrite core with magnetic material N27. The transformer has 15 windings, every winding has 10 turns made of copper conductor with $0.6 \mathrm{~mm}^{2}$ cross-section area (Fig. S3.7). Such design of transformer allows us to connect the windings in various manners according the experimental investigation scenario.

Table S3.1. Transformer windings connection variants

\begin{tabular}{|l|l|l|}
\hline $\begin{array}{l}\text { Variant } \\
\text { number }\end{array}$ & $\begin{array}{l}\text { Numbers of series connected windings, } \\
\text { which form secondary winding }\end{array}$ & $\begin{array}{l}\text { Numbers of windings connected in } \\
\text { parallel, which form primary } \\
\text { winding }\end{array}$ \\
\hline 1 & $7,8,9,10,11,12$ & $1,2,3,4,5,6$ \\
\hline 2 & $1,2,3,4,5,6$ & $7,8,9,10,11,12$ \\
\hline 3 & $1,2,3,10,11,12$ & $4,5,6,7,8,9$ \\
\hline 4 & $4,5,6,7,8,9$ & $1,2,3,10,11,12$ \\
\hline 5 & $4,5,6,10,11,12$ & $1,2,3,7,8,9$ \\
\hline 6 & $1,3,5,7,9,11$ & $2,4,6,8,10,12$ \\
\hline 7 & $1,4,5,7,10,11$ & $2,3,6,8,9,12$ \\
\hline
\end{tabular}

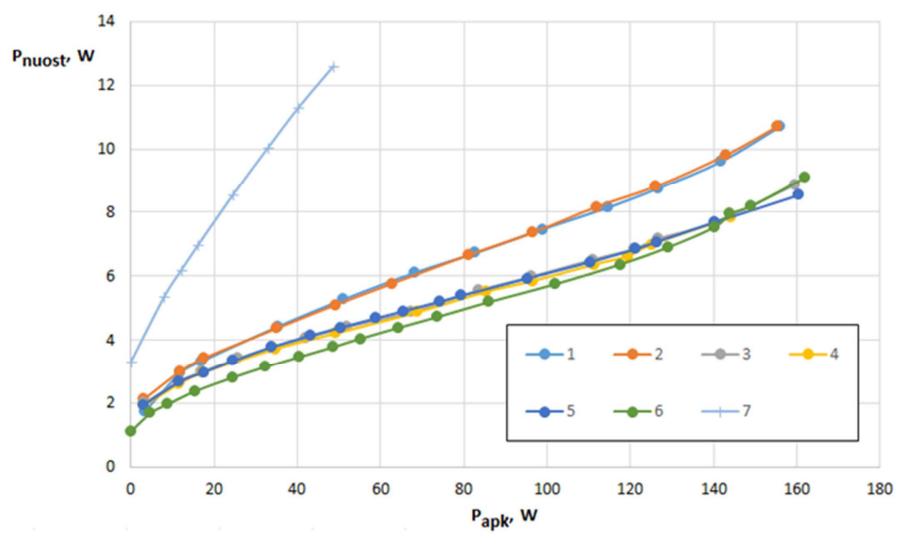

Fig. S3.8. The dependence of power losses in the clamping circuit on the output power at transformer windings connection variants $1-7$ (Table S3.1.)

The power generated by the voltage spike is dissipated in passive voltage spikes clamp circuit, which has to be used to lower amplitude of spikes. Therefore, the power losses in the clamp circuit can serve as a criterion for the evaluation of the transformer design: lower power losses mean lower voltage spikes. 
The results presented in Fig. S.3.8. show that the lowest power losses provides windings connection variant No. 6 proposed by the author. It was named as "chessboard method".

\section{General conclusions}

1. The developed two-switch DC/DC voltage flyback converter has less electronic components compared to the classic one and is characterized by the simpler control of MOSFET switches. The efficiency of this converter at $80 \mathrm{~W}$ power and $36 \mathrm{kHz}$ switching frequency is 0.918 , while that of the classic one is 0.895 , i.e. $2.3 \%$ higher.

2. The efficiency of the developed single-stage grid tied microinverter reaches a maximum value of 0.94 at switching frequency of $36 \mathrm{kHz}$ and an output power of $45 \mathrm{~W}$.

3. The proposed PI controller with the time-varying proportional constant comparing with the classical PI controller allows reducing the total harmonic distortions (THD) of the microinverter output current by at least $30 \%$ when the electrical grid voltage is undistorted and by at least $7 \%$ when the grid voltage is distorted by the 3rd and 5th harmonics.

4. The efficiency of the single-stage microinverter can be increased by reducing the active resistance of the primary winding of the flyback transformer and open transistor resistance of inverter MOSFET switches. Meanwhile, the active resistance of the secondary winding of the flyback transformer and the resistance of the open transistor of the MOSFET switches used in it, does not affect the efficiency of the microinverter.

5. The minimum power losses in the voltage suppression circuit due to voltage spikes caused by switching of the flyback transformer primary winding are achieved when the transformer windings are arranged according to the proposed "chessboard" principle. 



\title{
Priedai $^{3}$
}

\begin{abstract}
A priedas. Disertacijos autoriaus sąžiningumo deklaracija B priedas. Bendraautorių sutikimai teikti publikacijų medžiagą disertacijoje

C priedas. Autoriaus mokslinių publikacijų disertacijos tema kopijos
\end{abstract}

${ }^{3}$ Priedai pateikiami pridètoje kompaktinèje plokštelèje. 
Edvardas BIELSKIS

ENERGETIŠKAI EFEKTYVAUS FOTOVOLTINIO MIKROINVERTERIO KŪRIMAS

Daktaro disertacija

Technologijos mokslai,

elektros ir elektronikos inžinerija (T 001)

\section{DEVELOPMENT OF ENERGY EFFICIENT PHOTOVOLTAIC MICROINVERTER}

Doctoral Dissertation

Technological Sciences,

Electrical and Electronic Engineering ( $\mathrm{T}$ 001)

Saulètekio al. 11, 10223 Vilnius,

http://leidykla.vgtu.lt

Spausdino UAB "BMK leidykla“

A. Mickevičiaus g. 5, LT-08119 Vilnius 